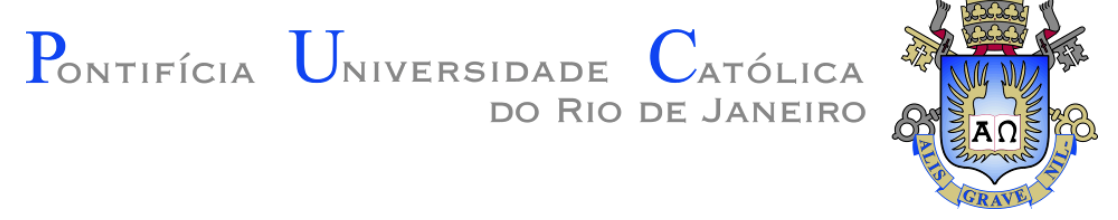

Miguel Borba de Sá

\title{
HAITIANISMO: \\ COLONIALIDADE E BIOPODER \\ NO DISCURSO POLÍTICO BRASILEIRO
}

Tese de Doutorado

Tese apresentada ao Programa de Pós-Graduação em Relações Internacionais da PUC-Rio como requisito parcial para obtenção do grau de Doutor em Relações Internacionais.

Orientador: Prof. João Franklin Abelardo Pontes Nogueira 
Todos os direitos reservados. É proibida a reprodução total ou parcial do trabalho sem autorização da universidade, do autor e do orientador.

\section{Miguel Borba de Sá}

Graduou-se como bacharel e licenciado em História, em 2005, pela Universidade Federal do Rio de Janeiro (UFRJ). Em 2009, concluiu seu mestrado em Relações Internacionais pela Pontifícia Universidade Católica do Rio de Janeiro (PUC-Rio) e, em 2010, tornou-se mestre em Ideologia e Análise de Discurso no departamento de Government da Universidade de Essex (Inglaterra). É membro do Laboratório Interdisciplinar de Estudos em Relações Internacionais da Universidade Federal Rural do Rio de Janeiro (Lieri-UFRRJ) e sócio do Instituto Políticas Alternativas para o Cone Sul (PACS).

Ficha Catalográfica

Sá, Miguel Borba de

Haitianismo: colonialidade e biopoder no discurso político brasileiro / Miguel Borba de Sá ; orientador: João Franklin Abelardo Pontes Nogueira. - 2019.

283f. ; $30 \mathrm{~cm}$

Tese (doutorado)-Pontifícia Universidade Católica do Rio de Janeiro, Instituto de Relações Internacionais, 2019.

Inclui bibliografia

1. Relações Internacionais - Teses. 2. Haitianismo. 3. MINUSTAH. 4. Intervenções humanitárias. 5. Relações Sul-Sul. 6. Colonialidade. I. Nogueira, João Franklin Abelardo Pontes. II. Pontifícia Universidade Católica do Rio de Janeiro. Instituto de Relações Internacionais. III. Título. 
Para Marielle Franco. 


\section{Agradecimentos}

Gostaria de agradecer à Coordenação de Aperfeiçoamento de Pessoal de Nível Superior do Ministério da Educação e à Fundação Carlos Chagas de Amparo à Pesquisa do Estado do Rio de Janeiro pelas bolsas de estudo concedidas para que esta investigação fosse possível. Igualmente, sou grato à Pontifícia Universidade Católica e seu Instituto de Relações Internacionais pela oportunidade de realizar esta pesquisa. Aos colegas professores, alunos e funcionários, obrigado pela companhia durante estes anos em que lecionei, pesquisei e estudei neste instituto. Sobretudo, devo especial agradecimento ao meu orientador, Prof. João Pontes Nogueira, pela inestimável ajuda com a investigação do Haitianismo, por sua disponibilidade, interesse e incentivo, sem os quais certamente esta tese não teria acontecido, além de ter sugerido e viabilizado o trabalho de campo no Haiti.

Neste país, fui recebido com carinho pela equipe da Plataforma Haitiana de Advocacia por um Desenvolvimento Alternativo, notadamente por Camille Chalmers, que me forneceu hospedagem, contatos, livros, experiências e vasto conhecimento. Sem a inestimável ajuda do economista Jean Pierre Jorés, que me acompanhou por toda parte como intérprete e interlocutor sobre o tema da pesquisa, o trabalho de campo teria sido inútil e desagradável. Um dos frutos que levo desta investigação é a sua amizade. Sou grato aos companheirxs da Brigada Dessalines do Movimento dos Trabalhadores Rurais Sem-Terra (MST), que me acolheram logo que cheguei e me ensinaram tanto sobre as relações de poder no Haiti, notadamente aquelas em que a força de ocupação se envolvia. Agradeço também à Mariana Tamari por me acompanhar em parte desta intensa viagem.

No Brasil, gostaria de agradecer ao Instituto Políticas Alternativas para o Cone Sul, especialmente à Sandra Quintela, por ter me permitido fazer parte das campanhas pela retirada das tropas da MINUSTAH desde minha primeira semana de trabalho em 2010, assim como pela compreensão e apoio que tive ao deixar o escritório para me dedicar à pesquisa justo deste tema. Da mesma maneira, sou 
grato às Redes Jubileu Sul Brasil e Américas por tantos encontros, saberes e experiência adquirida na luta pela reparação da dívida histórica cujos povos da América Latina e Caribe são os credores. Rosilene Wansetto, Ana Rogéria, Martha Flores e Beverly Keene sempre me estimularam (e cobraram) muito nesta jornada que tem no Haiti um exemplo de inspiração e comprometimento. Também agradeço à União Social dos Imigrantes Haitianos, especialmente a Fedo Bacourt, pela oportunidade de fazer parte, ainda que modestamente, do apoio à esta bela iniciativa.

Neste espaço tive a chance de fazer palestras sobre o Haitianismo e a MINUSTAH, onde colhi valiosas contribuições para a pesquisa. O mesmo aconteceu na Universidade do Estado do Haiti junto aos professores Camille Chalmers e Yves Dorestal; na Universidade Federal do Rio de Janeiro, onde anualmente fui convidado para dar aulas sobre o tema pela professora Luciene Lacerda, do curso de Defesa e Gestão Estratégica Internacional (DGEI); e também no IRI/PUC, onde a professora Maíra Siman Gomes gentilmente me convidou para apresentar a pesquisa para sua turma de pós-graduação. No DGEI, enquanto estive como professor substituto em 2013 e também depois, fui convidado para palestrar em eventos, como a Semana de Defesa, que foram importantes para consolidar este objeto e minhas convicções. Agradeço, em especial, ao brilhante Luã Braga pelos convites, assistência de pesquisa e estímulo nos momentos iniciais desta investigação.

Aos colegas de doutorado, muito obrigado pelo companheirismo, lições e paciência comigo. Sem a cumplicidade de vocês, acho que não teria prosseguido, especialmente a de Geovana Zoccal, com quem tenho uma dívida de gratidão infinita, tamanha foi a ajuda que me deu em diversas dimensões ao longo destes anos. Desde as primeiras aulas, no processo de qualificação e até nas fases finais de escrita desta tese pude aprender com sua inteligência e profissionalismo, assim como desfrutar da sua generosidade sem fim.

Gostaria de agradecer ainda pela interlocução intelectual, parcerias de trabalho militante e incentivos recebidos das mentes brilhantes (e corações gigantes) de Brenda Fonseca, Bruno Garcia, Caio Almendra, Cunca Bocayuva, 
Diego Gois, Gizele Martins, Isabella Mendes, Julia Bustamante, Karina Kato, Luiz Feldman, Marcos Arruda, Marina Motta, Maureen Santos, Natália Rayol, Regis Costa, Roberto Yamato, Rob Walker e Verônica Freitas. Apesar de não serem responsáveis pelos erros e limitações do presente trabalho, sua contribuição direta para que esta tese fosse escrita é grande, seja pelas conversas, leituras prévias, esclarecimentos ou críticas que me forçaram a aprimorar o argumento. Sobretudo, sou grato pelo interesse que dispensaram ao tema e ao meu posicionamento nele. Especialmente às professoras Ana Garcia e Rafaela Souza, por tanta ajuda.

Por fim, eu não estaria aqui hoje agradecendo a ninguém não fosse pela convivência diária com aqueles que são a melhor família que se poderia desejar (como diz o ditado, seu sangue até pernilongo tem): Aline, Ana Beatriz, Antonio, Cláudio, Damiana, Dr. Paulo, Emilia, Eurico, Frassinette, Iyá Lúcia, Leandro, Leo, Java, Joana, Naná, Renata, Ricardo, Rodrigo, Riomar, Salac, Sofia, Thamires, Theo e Vanessa(s) estiveram comigo nos momentos, nem sempre fáceis, vividos ao longo desta pesquisa, com carinho, palavras e gestos de conforto. Muito obrigado.

O presente trabalho foi realizado com apoio da Coordenação de Aperfeiçoamento de Pessoal de Nível Superior - Brasil (CAPES) - Código de Financiamento 001. 


\section{Resumo}

Borba de Sá, Miguel; Pontes Nogueira, João Franklin Abelardo (orientador). Haitianismo: colonialidade e biopoder no discurso político brasileiro. Rio de Janeiro, 2019, 283p. Tese de Doutorado - Instituto de Relações Internacionais, Pontifícia Universidade Católica do Rio de Janeiro.

Esta tese investiga os modos em que o Haiti é evocado no discurso político brasileiro em diferentes contextos. Usufruindo de enquadramentos analíticos póscoloniais e foucaultianos, foca-se em duas grandes emergências desta prática discursiva: primeiro, com o inovador léxico do Haitianismo, durante os debates políticos do Império Brasileiro, no século XIX; depois, no âmbito do envolvimento brasileiro com a Missão das Nações Unidas para Estabilização do Haiti (MINUSTAH), de 2004 a 2017. O estudo mostra que as atuais narrativas que celebram o sucesso de um 'Jeito Brasileiro' de construção da paz falham em notar como noções problemáticas de hierarquias raciais e tecnologias mais eficientes de poder governamental são desenvolvidas e exercidas sobre as populações-alvo. Argumenta-se que, sob o prisma do Haitianismo, tais discursos celebratórios das intervenções militares Sul-Sul perdem seu apelo político e consistência teórica, já que a colonialidade e o biopoder que os informam são expostos e sua originalidade questionada. Conclui-se notando que o estudo do Haitianismo permite seguir descolonizando e resistindo à autoridade dos modos emergentes de complexos de poder-saber humanitários, incluindo aqueles que estão além do modelo tradicional da Paz Liberal.

\section{Palavras-chave}

Haitianismo; MINUSTAH; Intervenções Humanitárias; Relações Sul-Sul; Colonialidade. 


\section{Abstract}

Borba de Sá, Miguel; Pontes Nogueira, João Franklin Abelardo (Advisor). Haitianism: coloniality and biopower in Brazilian political discourse. Rio de Janeiro, 2019, 283p. Tese de Doutorado - Instituto de Relações Internacionais, Pontifícia Universidade Católica do Rio de Janeiro.

This doctoral dissertation investigates the modes in which Haiti is invoked in Brazilian political discourse in different contexts. Drawing on post-colonial and Foucauldian frameworks of analysis, it focuses on two major emergences of such discursive practice: first, with the innovative lexicon of Haitianism, during $19^{\text {th }}$ century Brazilian Imperial political debates; then, alongside Brazilian involvement with the United Nations Stabilization Mission in Haiti (MINUSTAH), from 2004 to 2017. The study shows that current narratives that celebrate a 'Brazilian way' of peacebuilding fail to notice how problematic accounts of racial hierarchies and more efficient governmental technologies of power are developed and exercised upon target populations. It argues that through the prism of Haitianism such celebratory discourses regarding South-South military interventions lose their political appeal, as the coloniality and biopower that inform them are exposed and their originality questioned. It concludes by noticing that the study of Haitianism permits to further decolonize and resist the authority of emerging humanitarian power-knowledge complexes beyond the traditional Liberal Peace model.

\section{Keywords}

MINUSTAH; Haitianism; Humanitarian Interventions; South-South relations; Coloniality. 


\section{Sumário}

CAPÍTULO 1: Introdução 11

1. Apresentação 11

2. Revolução Haitiana: História e Relações Internacionais 13

3. Oliveira Vianna: um apêndice no século XX 15

4. Estrutura de capítulos $\quad 21$

CAPÍTULO 2: O intervencionismo e seus críticos: a Paz Liberal e o Haiti 24

1. A Paz Liberal nas Relações Internacionais 24

2. Neoliberalismo, biopoder, agendas domésticas e colonialidade $\quad 27$

3. A Paz Híbrida nas Relações Internacionais 38

4. MINUSTAH e as críticas acadêmicas à intervenção no Haiti 43

5. Críticas à MINUSTAH para além da academia 55

6. Considerações finais 61

CAPÍTULO 3: Historiografia brasileira do Haitianismo e da Revolução no Haiti 63

1. O Haiti e o Haitianismo como exemplo e inspiração 64

2. O "novo Haiti" e o Haitianismo como medo branco no Brasil 72

3. Obras clássicas e abordagens inovadoras 78

4. O conceito de Haitianismo textualmente analisado 83

5. O Haiti nas fontes primárias sem o conceito de Haitianismo 90

6. Considerações finais 96

CAPÍTULO 4: Haitianismo: colonialidade e biopoder na produção do Brasil 99

1. Suspensão ou redução de direitos 101

2. Corpos negros no discurso do Haitianismo 110

3. Insulto político e pessoal: Haitiano como antibrasileiro 112

4. Segurança pública, militarização e exceção fiscal 119

5. Eleições, conspirações e rusgas políticas: o Haitianismo em ação 122

6. Haitianismo e democracia racial 132

7. Considerações finais 143 
CAPÍTULO 5: MINUSTAH: colonialidade e biopoder em ação no Haiti

1. Origem da intervenção 148

2. O discurso brasileiro sobre o sucesso da MINUSTAH 150

3. Narrativas de caos e produção da ordem 157

4. Posicionamento de sujeitos: Brasil/Haiti (Brasileiros/Haitianos) 172

5. Teleologias de modernização e amadurecimento do Outro 187

6. Considerações finais 199

CAPITULO 6: A MINUSTAH como Haitianismo 204

1. Regularidades e formações discursivas: a arqueologia do Haitianismo

1.1 Formação discursiva dos saberes do Haitianismo século XIX

1.2 Formação discursiva do modelo brasileiro de paz 213

2. Emergência e descontinuidade: rumo à genealogia do Haitianismo

3. A MINUSTAH como Haitianismo

4. Paz Híbrida ou Paz Haitianista?

5. Considerações finais 


\section{CAPÍTULO 1: Introdução}

\section{Apresentação}

Esta tese trata do Haitianismo como um dispositivo de poder característico de formações discursivas pós-coloniais que, não sendo restrito ao passado, é reativado em contextos espaço-temporais renovados. Para tanto, toma como instância exemplar desta reativação os discursos sobre o sucesso da participação brasileira na Missão das Nações Unidas para Estabilização do Haiti (MINUSTAH). Entre julho de 2004 e outubro de 2017, o país caribenho esteve sob tutela de forças militares de ocupação e de autoridades civis estrangeiras com mandato outorgado pelo Conselho de Segurança das Nações Unidas (CSNU). O comando do componente armado desta missão foi exercido por generais brasileiros durante os treze anos de intervenção internacional no Haiti, assim como o maior contingente de tropas foi sempre de origem brasileira.

Embora não tenha havido um balanço criterioso dos resultados obtidos e as informações sobre o estado atual do Haiti sejam escassas (ou inexistentes), tanto na imprensa, como no universo acadêmico do Brasil, as narrativas que celebram o êxito do 'modelo brasileiro' de pacificação continuam a predominar da mesma forma que fizeram durante a última década. Mesmo com as denúncias sobre violações de direitos humanos levadas a cabo por movimentos sociais, organizações da sociedade civil, intelectuais, artistas e personalidades políticas de prestígio, as campanhas pela retirada das tropas do Haiti tiveram pouca visibilidade e impacto reduzido ao longo dos anos de ocupação militar. Os esforços para se construir uma narrativa alternativa esbarraram na assimetria de forças, recursos materiais e poder de difusão frente ao discurso hegemônico que se construiu sobre o tema, cujo lema foi, e segue sendo, "Brasil no Haiti: um caso de sucesso" (MENDONÇA, 2017, p. $58)$.

A tese que ora se apresenta é fruto de uma pesquisa sobre este regime discursivo, que exalta uma suposta particularidade do Brasil para realizar tais operações, tornando este país melhor preparado que outros para desempenhar este tipo de intervenção. A estratégia analítica empregada optou por não discutir se 
houve êxito ou não (julgamento que é, naturalmente, questionável e depende dos parâmetros empregados por cada avaliação), mas interrogar minunciosamente que tipo de sucesso está sendo propalado quando assim se descreve a liderança, sobretudo militar, do Brasil na MINUSTAH. Em outras palavras, investigar o que está em jogo neste regime de verdade que se estabeleceu em torno do "modelo brasileiro" de atuação nesta missão (KENKEL, 2011, p. 28; SEITENFUS, 2006, p. 7).

Para tanto, recorreu-se ao estudo do Haitianismo, fenômeno discursivo e político de relevo no Brasil do século XIX, especialmente durante o Período Regencial (1831-1840) do Império Brasileiro. Esta foi outra importante instância de enunciação de narrativas envolvendo o Haiti pelo discurso político brasileiro. Conforme a historiografia sobre o tema informa, também se tratava da discussão sobre modelos, mas, neste caso, versando sobre as formas de escravidão, independência e construção dos Estados pós-coloniais no Brasil e no Haiti. Sobretudo, temia-se o exemplo que a Revolução Haitiana poderia proporcionar. E foram desenvolvidos mecanismos para assegurar que isto não ocorresse.

$\mathrm{O}$ argumento central desta tese é que, sob o prisma do Haitianismo, o discurso simpático ao "jeito brasileiro" de praticar operações de paz (Abdenur \& Call, 2017, p. 10; Carvalho, 2017, p. 49; Clauhs, 2013, p. 108; Kalil \& Napoleão, 2015, p. 102) perde seu apelo político e sua consistência teórica, revelando-se como a reativação de expedientes de controle sociorracial já conhecidos. Mediante uma análise que combina elementos do pensamento decolonial e pós-colonial com abordagens foucaultianas, sugere-se tratar ambas as instâncias de mobilização do Haiti pelo discurso político brasileiro como integrantes de uma mesma genealogia. Isto permite observar o funcionamento deste complexo emaranhado de saberes e tecnologias de gestão de populações racializadas como não brancas, ora apresentadas como frágeis, ora como perigosas, mas que sempre requerem especial atenção para que a paz e a ordem social sejam mantidas.

Como se tratam de práticas discursivas cujos efeitos de poder são os mesmos, i.e., a manutenção do status quo sociorracial e político, é preciso lançar mão de ferramentas que permitam conceber como a colonialidade do poder (Quijano, 2005) é constitutiva tanto da escravidão racializada quanto do atual intervencionismo sobre territórios que, no passado, foram objeto de conquista das metrópoles ocidentais. Pois é deste modo que a militarização do mundo pós- 
colonial se articula com as relações de poder escravistas; é assim que hoje a “biopolítica se enreda com a geopolítica” (CASTRO-GÓMEZ, 2007, p. 161). Por isto, a fim de resistir ao poder dos enunciados sobre o sucesso do Brasil no Haiti é adequado - quiçá necessário - entender a MINUSTAH como Haitianismo.

\section{Revolução Haitiana: História e Relações Internacionais}

Apesar da historiografia brasileira sobre o Haitianismo tratar o tema a partir da ótica das repercussões ou impactos da Revolução Haitiana no Brasil escravista, esta tese pôde explorar entendimentos mais complexos sobre o assunto. Como será visto adiante, as alusões aos acontecimentos revolucionários no Haiti, entre 1791 e 1804, não são exatamente congruentes com a cunhagem e utilização do conceito de Haitianismo pelas elites políticas e intelectuais do Império Brasileiro. Isto não significa que esta revolução seja desprovida de significados profundos para todo o mundo atlântico, incluindo o Brasil. Pelo contrário, a estratégia analítica aqui empregada parte da convicção de que este acontecimento ímpar na história da humanidade permanece crucial para o entendimento de dinâmicas políticas internacionais até os dias de hoje, incluindo a própria MINUSTAH.

É preciso retificar, no entanto, a noção simplista que amalgamou o Haitianismo (conceito que existiu apenas no Brasil) com toda sorte de repercussões, impactos e influências da Revolução Haitiana alhures. A presente pesquisa constatou que, mesmo que a alusão ao Haiti revolucionário seja inescapável, seria por demais reducionista - e enganoso - compreender o Haitianismo a partir de uma simples relação de causa e efeito, como se fosse uma espécie de efeitotransbordamento (spillover effect) deste evento sobre o Brasil. O Haitianismo é mais do que isso. Por isso, a sua relevância para a análise crítica de questões contemporâneas também é maior do que geralmente percebida. Há, pois, um potencial heurístico e um poder político que não deveriam ser subestimados.

Sobre a Revolução Haitiana e suas implicações para as Relações Internacionais, há uma série de trabalhos de qualidade que podem ser consultados. Autores como David Scott (2004), Munro e Shilliam (2011), Porto-Gonçalves (2006), Franck Seguy (2014) e Sibylle Fischer (2004) têm destacado como o Haiti, tanto o colonial como o revolucionário, deve ser entendido como fonte de pioneirismo na instauração da modernidade e do cosmopolitismo. Por sua vez, Susan Buck-Morss (2011) demonstra como o pensamento filosófico do Iluminismo 
é tributário das lutas sociais contra a escravidão no Haiti, mesmo que isto não seja reconhecido. Edward Said (1994), por outro lado, defende que na literatura sobre a Revolução Haitiana pode-se encontrar uma forma de crítica aos universalismos que conectaram cultura e imperialismo por séculos, mas que em obras como a de James (1989) mostram um caminho "na história humana que pode mover-nos da história da dominação para a realidade da liberação" (SAID, 1994, p. 340). Apesar disto, o Haiti permanece praticamente ausente na literatura do mainstream sobre a História das Relações Internacionais, sendo lembrado apenas como objeto de intervenções como a MINUSTAH.

Os historiadores deram mais atenção ao Haiti, ainda que não o suficiente. Este trabalho de C.L.R. James (1989), Os Jacobinos Negros, continua sendo a referência obrigatória nos estudos sobre o tema e suas conexões com a política internacional, uma vez que conta a história da própria Revolução Francesa de uma maneira que precisa necessariamente incluir o Haiti, além de servir como metáfora para uma crítica da guinada stalinista na Revolução Soviética (o livro foi escrito originalmente em 1938). A influência internacional do movimento liderado por Toussaint L'Ouverture e Jean-Jacques Dessalines também é ressaltada pelo clássico de Eugene Genovese (1979), Da Rebelião à Revolução. Mais comentado (e criticado) do que lido, este livro estabelece uma tese similar à de James (1989), uma vez que se dedica a mostrar o papel das revoltas escravas afro-americanas na construção do mundo moderno, com destaque para o impacto da Revolução Haitiana sobre a resistência contra a escravidão nos Estados Unidos da América. $\mathrm{O}$ Brasil é mencionado em diversas passagens, especialmente quando trata da Revolta dos Malês, em 1835, sobre a qual conclui: "Bahia had come close to becoming another Haiti"' (GENOVESE, 1979, p. 32).

Ainda sobre as conexões da Revolução Haitiana com a política mundial de seu tempo há outros trabalhos historiográficos de qualidade, como o de Robin Blackburn (2006) que insere este tema no contexto da Era das Revoluções Democráticas. Linha similar havia sido traçada por David Geggus (1989) que, junto a Laurent Dubois (2004), figura como o grande especialista em Revolução Haitiana em atividade nos dias de hoje. Este último é autor de um trabalho seminal (Avengers of the New World: the story of the Haitian Revolution) cujo fôlego, elegância narrativa e cuidado no trato com fontes primárias são comparáveis aos de James (1989). Acerca dos efeitos-transbordamento sobre sociedades escravistas vizinhas 
ao Haiti, é importante consultar os trabalhos de Ada Ferrer (2012), sobre Cuba, e David Geggus (1981), sobre a Jamaica. E para a região do Grande Caribe em geral, Alejandro Gómez $(2005,2006)$ oferece detalhadas análises sobre aquilo que denominou como síndrome de São Domingos em lugares onde houve grande sensibilidade com relação aos acontecimentos da Revolução Haitiana.

Por fim, é pertinente notar que o bicentenário da Revolução Haitiana, em 2004, ensejou uma renovada onda de interesse sobre o tema, sendo que parte dos trabalhos mencionados acima são fruto deste movimento de romper com o Silenciamento do Passado que havia sido percebido por Michel-Rolph Trouillot (1995) em seu famoso livro sobre o poder e a produção da história. Para uma visão geral desta renovação dos estudos, pode-se recorrer aos apontamentos de Anja Bandau (2013) e Peter Hallward (2004).

Estes trabalhos certamente não esgotam a quantidade de fontes que se pode consultar sobre o assunto. Oferecem, contudo, portas de entrada confiáveis para uma iniciação nos debates sobre a Revolução Haitiana em perspectiva histórica, assim como em seus nexos com o estudo crítico das Relações Internacionais, ontem e hoje.

\section{Oliveira Vianna: um apêndice no século $X X$}

Esta pesquisa aborda com especial ênfase os usos do Haiti durante o Período Regencial do Império Brasileiro, no século XIX, e no âmbito da intervenção humanitária da MINUSTAH, no século XXI. No entanto, houve outras épocas que produziram amostras deste recurso ao Haiti pelo discurso político brasileiro. Esta seção apresenta uma destas instâncias, que também poderia ser entendida como exemplo de Haitianismo. Mas por fugir do escopo da presente tese, este caso ficará restrito a um breve apêndice descritivo.

Na primeira metade do século XX, o pensador conservador Oliveira Vianna causou polêmica ao dedicar um capítulo de sua obra Problemas de Política Objetiva $(1930)^{1}$ à defesa da intervenção norte-americana no Haiti, iniciada quinze anos antes. Nas sete páginas de seu capítulo, intitulado O Conceito Pragmático da Liberdade Política, o autor dedica-se a criticar aquilo que chama de "antigo idealismo da soberania do povo", de modo a defender a superioridade filosófica e prática do "moderno idealismo pragmático" (1930, p. 70). Para tanto, recorre ao

\footnotetext{
${ }^{1} \mathrm{O}$ autor gostaria de agradecer a Luiz Feldman pela indicação desta obra de Oliveira Vianna.
} 
domínio norte-americano sobre o Haiti como forma de demonstrar a inadequação dos postulados dos "liberais da velha escola da soberania do povo e os da moderna escola da self-determination" (1930, p. 69). ${ }^{2}$ O pragmatismo reclamado seria alcançado pela análise capaz de priorizar resultados concretos por sobre princípios abstratos. $^{3}$

Ele parte então para uma contraposição, por vezes satírica, entre o Haiti antes da invasão dos EUA (chamado de "Haiti livre") com o país após a ocupação (chamado de "Haiti escravizado"). O texto se dedica a mostrar a superioridade do segundo frente ao primeiro e a necessidade de intervir diante de tal quadro. "No Haiti do tempo da liberdade", segundo esta ótica, faltava de tudo. Especialmente os meios de produção da ordem: "não havia propriamente governo", diz Vianna (1930, p. 71). Esta afirmação é fundamentada em um sentido realista de RI, a partir da constatação da falta de monopólio estatal sobre a violência legítima. "Em primeiro lugar, não havia polícia nem exército", diz o pensador brasileiro, agregando que "o exército e a polícia não passavam de bandos armados, de que os caudilhos políticos se serviam como instrumento de suas lutas pelo poder". Neste estado de natureza prévio à intervenção, "dominava um regime de banditismo endêmico" e "não havia, portanto, nem defesa nacional nem ordem pública" (1930, p. 71).

Para defender que “o domínio americano é justíssimo”, Vianna (1930, p. 70) argumenta que uma espécie de Leviatã, criado desde o exterior, foi imposto para que aquele espaço pudesse sair do estágio descrito e entrasse na modernidade, graças aos que "começam a governar o Haiti à sua maneira, isto é, à maneira yankee" (1930, p. 71). O momento fundacional de instauração estatal é destacado

\footnotetext{
${ }^{2}$ Todo o capítulo de Vianna (1930) é baseado sobre uma única fonte bibliográfica que, segundo ele, bastaria para compreender o Haiti, uma vez que o autor possuiria as credencias epistemológicas e nacionais (ou raciais) adequadas: um "espírito perfeitamente americano, isto é, pragmatista" (1930, p. 69). Trata-se do artigo de: Ulysses, Weatherley. "Haiti: An Experiment in Pragmatism". The American Journal of Sociology, November, 1926.

${ }^{3}$ Interessante notar que a análise feita por Vianna (1930) segue linhas similares as do chamado realismo do $1^{\circ}$ grande debate de RI; mas o exemplo trazido é justamente proporcionado pelo ícone dos chamados utópicos ou idealistas liberais neste debate, Woodrow Wilson, responsável pela decisão de invadir o Haiti em 1915. Foi, portanto, a agressão externa de Wilson que ensejou o elogio de Vianna (1930) e não as ideias de autodeterminação dos povos, pacifismo e democracia, pelas quais é conhecido em RI - princípios solapados pela intervenção norte-americana na ilha caribenha. As tropas só deixariam o país em 1934, durante a Grande Depressão nos EUA. Para uma visão crítica da ocupação militar do Haiti pelos EUA ver, dentre outros: Bonilla (2013), Macleod (2011), Perchellet (2010, p. 44-49), Pierce (1981, p. 8-22) e Ulysse (2015).

${ }^{4}$ Sobre a linhagem dos discursos da "política de poder estatista", chamados realistas na teoria de RI, e seus expoentes mais frequentemente citados, como Thomas Hobbes, ou menos confortavelmente admitidos, como Max Weber ou Carl Schmidt, ver Walker (2013, p. 244-249).
} 
pelo autor, que acredita ser o começo de uma nova história do Haiti, quando "os destinos" do país passam a ser "dirigidos por funcionários americanos": os EUA, segundo ele, "começam a refundir, a reformar, a reorganizar tudo - isto é, a governar" (1930, p. 73). Diante de tais medidas, sua conclusão era que, apesar de perdida a soberania nacional e popular, ou justamente por causa desta subtração operada por força exterior, o "Haiti é hoje um dos países mais pacíficos e ordeiros do mundo" (1930, p. 75), devido às técnicas de governamentalidade empregadas pelos interventores:

Não é só. O exército e a polícia se haviam tornado instrumentos dos políticos facciosos. Os americanos dissolvem um e outro, e organizam, em substituição, uma sorte de milícia nacional, já agora disciplinada e comandada por oficiais americanos: e com ela restabelecem a ordem pública. Nos grandes focos de banditismo do norte fazem o que o professor Weatherley chama - "uma cura por ventilação". O que gerava o banditismo era a inacessibilidade daquela região setentrional à ação policial do poder. Ora, os americanos compreenderam logicamente (lógica pragmática...) que o que se fazia preciso era corrigir esta inacessibilidade, quebrar esta impenetrabilidade, em suma "ventilar" a região: e a rasgam de estradas, e a cobrem de rodovias, e conduzem até ali o telégrafo e o telefone; de modo que os automóveis carregados de polícia embalada puderam circular em todas as direções, ao primeiro chamado. (1930, p. 74)

Junto dos discursos de caos e ordem que criam condições de possibilidade, ou mesmo a necessidade, de intervir para sanar o país ("cura por ventilação"), o texto de Vianna (1930) também apresenta uma série de ontologias de alteridade, que destacam diferenças culturais entre os países interventores e aqueles que são alvo de tais ações, no caso o Haiti. Ele segue explorando cenas de desordem e aproveita para decorá-las com adereços literários de colonialidade erudita. Após comparar o "banditismo endêmico" haitiano com o "dos nossos altos sertões", 5 indicando que o primeiro caso seria mais grave, procura-se desqualificar, mediante sarcasmo e racismo, as lideranças políticas do Haiti "livre e soberano" (1930, p. 71):

Desses Curralinhos, desses Pajeús de Flores, desses Inhamuns haitianos, patriotas salvadores faziam descer frequentemente algaras armadas sobre a capital do país, situada ao sul, no intuito de depor os adversários, senhores do governo. E isto estabelecia no país um estado de desordem crônica, sob o qual a ordem pública desaparecia completamente. $(1930, \text { p. } 71-72)^{6}$

\footnotetext{
${ }^{5}$ Vianna (1930, p. 74) também chama o "banditismo haitiano" de "Lampiões", em alusão ao famoso cangaceiro brasileiro Virgulino Ferreira da Silva, o Lampião.

${ }^{6}$ Inhamuns advém do Tupi-Guarani, Anhamuns. Significa "irmão do gênio mal da floresta", ou irmão do diabo. Os americanos, padrão superior de comparação, são descritos como civilizadores
} 
Filiando-se ao eurocentrismo de seu autor de referência e suas imagens sobre o Haiti - e colocando-se assim no lado superior da hierarquia civilizacional produzida por seu discurso - Vianna (1930) é taxativo quanto ao que resumiria o seu objeto de análise. Com doses carregadas de colonialidade em seu saber, ele diz: “'O professor Weatherley resume o Haiti 'livre e soberano' numa frase: a cultural débâcle" (1930, p. 72). O Haiti e sua cultura, são resumíveis, portanto, pela noção de fiasco, de acordo com este olhar proveniente de intelectuais dos EUA e do Brasil pós-coloniais.

Por fim, narrativas guiadas por teleologias da modernização fecham o conjunto de argumentos que buscam justificar a invasão estrangeira com base em seu trabalho de melhoramento do Haiti e dos próprios haitianos. Os interventores são narrados mediante alegorias missionárias, provendo os locais com uma "consciência sanitária", uma "cultura científica"; fundando "escolas de todo gênero" e "hospitais"; "drenando pântanos" (1930, p. 74). Os americanos "restauram" as finanças públicas e substituem o "absurdo" sistema de impostos por outro "racional e justo" (1930, p. 73), dentre outras benfeitorias materiais e intelectuais que alteram profundamente o quadro anterior de subdesenvolvimento encontrado no país, descrito mediante uma metafísica entre presença e ausência que enfatiza a falta naquilo que se toma por objeto de análise.

\begin{abstract}
Não havia justiça - porque os aparelhos judiciários estavam avassalados inteiramente pela politicalha das facções. Nem havia ensino, nem escolas - porque os governos, preocupados em defender-se dos seus inimigos, não tinham tempo para cuidar destas coisas. Não havia meios de comunicações - porque não existiam estradas, nem rodovias, ferrovias; nada. Não havia higiene pública, nem hospitais, nem organizações de profilaxia. Nas cidades - o povo morria devastado pela tuberculose; nos campos - pela malária e ancilostomose. (1930, p. 72)
\end{abstract}

Assim como na MINUSTAH, criada nove décadas após a primeira invasão norte-americana, o Haiti ocupado no início do século XX já era narrado por influentes vozes do mundo político brasileiro como passível e mesmo necessitado de uma intervenção modernizadora, sob discursos que enfatizam o altruísmo e outros aspectos do que hoje chama-se de paz liberal. O texto de Oliveira Vianna

destes selvagens. Para mais sobre esta nação indígena, conhecida por sua bravura e luta de resistência ao colonialismo luso-brasileiro, ver reportagem do Diário do Nordeste sobre a região em que os Inhamuns viviam, no atual estado do Ceará (acesso em Agosto de 2018):

http://diariodonordeste.verdesmares.com.br/cadernos/regional/populacao-preserva-raizes1.776539 . 
reforça pormenorizadamente tal prática ao acrescentar, na segunda edição da obra, em 1947, uma longa nota de rodapé (que se estende por três páginas completas), como forma de posicionar-se dentro da polêmica causada pelo texto desde sua publicação (VIANNA, 1947, p. 104-106).

Nela, Vianna (1947, p. 104) esquiva-se da acusação que sofrera de "justificar os imperialismos então em voga", quando da publicação original do livro, em 1930. Ao defender-se, o pensador brasileiro insere definitivamente seu argumento no futuro regime de segurança internacional que, a partir do final da Guerra Fria em diante, surgiria junto com a expansão das práticas intervencionistas sob viés humanitário. Tal regime, portanto, esboçara seus contornos teóricos (e políticos) já no final da Segunda Guerra Mundial, tendo sua aplicação prática sido colocada em modo de espera durante a disputa entre as duas superpotências do século XX. Mesmo ao defender-se, Vianna (1947) termina por reforçar a colonialidade e os clamores por incremento de biopoder já existentes em sua obra original. O Haiti aparece como responsável pela própria intervenção que sofre, em nome da "razão" (1947, p. 98), devido a sua falta de ordem e civilização:

Estas nações poderosas se haviam então arvorado em agentes civilizadores do resto do mundo. Civilizadores e policiadores - e este foi o caso do Haiti, cuja dominação pelos Estados Unidos teve por fundamento o estado crônico de desordem e turbulência em que vivia aquela gente (state of anarchy)

(...) $\mathrm{O}$ meu pensamento, entretanto, ao escrever este capítulo, não era, de modo algum, justificar os imperialismos conquistadores; mas, apenas mostrar, com um exemplo concreto - com o caso do Haiti - os perigos, em que incorrem os povos, que se deixam dominar pela politicalha de clã e pelo facciosismo. (1947, p. 104105 - itálico no original)

Após a Segunda Guerra, o ambiente político havia sido alterado e não era possível para Vianna (1947) manter ipsis litteris a mesma posição colonialista e radicalmente antidemocrática presente em sua obra original. Isto o obriga a fazer este tipo de remendo no texto, de modo a combinar seu afã modernizante com a ideologia e o sistema jurídico prevalecentes a partir de 1945. Ele crê encontrar no embrionário regime multilateral interventor o mecanismo de junção destas duas tendências normativas, outrora conflitantes: o princípio da autodeterminação; e a autoridade legal e fática do próprio sistema de Estados, sem a qual a soberania estatal perderia sua legitimidade e força. Uma nova ordem internacional baseada em princípios liberais e, ao mesmo tempo, missionários, já que arrogando-se o direito (ou mesmo o dever) de intervir em espaços cuidadosamente classificados 
pelo autor (em inglês) como locais onde existiria, como visto, um "state of anarchy" (1947, p. 105). Não se fala em raça explicitamente, ainda que a escolha do Haiti como exemplo de estado anárquico sutilmente sugira conotações raciais.

Para Vianna (1947), a educação de uma nação pela "grande comunidade internacional" do pós-guerra é comparável com o disciplinamento sofrido por indivíduos em suas relações familiares. Nesta "ordem internacional", a "intervenção" e o "controle" possuem feitio pedagógico. As sociedades que não forem consideradas como exemplos de "existência decente" serão "forçadas a enquadrar a sua estrutura política nos clássicos padrões da democracia e do liberalismo" (1947, p. 105). A anarquia internacional, portanto, estaria sendo substituída por uma sociedade de nações cuja tarefa seria a de eliminar as anarquias domésticas, segundo esta formulação. "Não se admite mais turbulentos na ordem internacional, nem mesmo que façam barulho portas adentro, em família” (p. 1947, p. 105).

Tudo está mostrando que o futuro dará ao direito de intervenção e policiamento internacional, postos nas mãos da futura Organização da Segurança Mundial a instituir-se, uma latitude enorme: e a ordem interna dos Estados tenderá a tornarse um capítulo apenas da ordem pública externa e a esta subordinada. Os Estados continuarão soberanos; mas, para gozarem a honra e a dignidade de figurar na comunidade internacional como tais - isto é, como nações soberanas - estarão já agora obrigados à exigência da folha corrida, ao termo de bem viver e à prova do bom comportamento em família. (1947, p. 106 - itálico no original)

Para o intelectual conservador brasileiro há pouca distinção em termos de princípios e objetivos entre o fardo do homem branco da era imperial e as intervenções multilaterais do pós-guerra. O que teria mudado seria a normatividade do internacional, agora mais habilmente legitimadora daquilo que antes causava polêmica e institucionalizando o que antes era feito de forma individual por cada grande potência. "O ambiente internacional está, hoje, muito modificado e é outro o tom das ideias: o que parecia execrável e digno de anátema então é hoje, ou tenderá a ser muito em breve, um critério pragmático da própria nova moral internacional" (1947, p. 106).

Dito de outra forma, o que reaparece nas agendas políticas conservadoras $e$ liberais do discurso político brasileiro, encarnado na trajetória adaptável de Oliveira Vianna, é o desejo comum por poder (controle/intervenção) sobre corpos considerados mais fracos ou menos evoluídos, provendo-lhes a vida, a democracia 
e a liberdade (ou liberalismo). E a colonialidade do poder investida pela certeza eurocêntrica de uma racionalidade que concebe seu papel, branco e governamental, sempre como benfeitor, salvador ou responsável pelo melhoramento de lugares como o Haiti e de pessoas como as haitianas, a quem faltariam os atributos materiais e intelectuais (raciais) típicos da modernidade ocidental. Nos termos desta tese, um tal dispositivo de poder assim acionado, com êxito, por vozes pós-coloniais, pode ser entendido como uma irrupção de Haitianismo.

Este regime discursivo, biopolítico e colonial, ativado na obra de Vianna (1947) sobre o Haiti ocupado serve como preâmbulo para introduzir as narrativas brasileiras atuais que constroem tecnologias de poder sobre o Outro ao defenderem a MINUSTAH. Trata-se, conforme prognosticado por este importante enunciador, de emergências de agendas políticas contrárias à soberania popular e à autodeterminação dos povos não brancos. Por isto, em suas acertadas palavras: "o caso do Haiti, estudado neste capítulo, foi apenas uma antecipação, um episódio profético" (1947, p. 106). Nisto ele tinha razão.

\section{Estrutura de capítulos}

O próximo capítulo trata da crítica ao intervencionismo multilateral no pósGuerra Fria e, mais especificamente, das abordagens críticas à MINUSTAH, dentro e fora da academia. Ele permite situar a presente tese nos debates sobre o tema da paz liberal nas Relações Internacionais. Em vez de revisar genericamente a ampla literatura sobre Peacekeeping, Peacebuilding e Peace Enforcement, optou-se por se debruçar mais detalhadamente sobre as abordagens que se reivindicam críticas de tais práticas e que, portanto, são mais úteis para a análise crítica da MINUSTAH que é feita em seguida. Tendo em vista que no Haiti não houve conflito armado ou guerra civil, a pertinência da distinção entre tais conceitos é duvidosa, sendo mais apropriado tratá-los como noções que, junto a outras, compõem o arsenal de possibilidades intervencionistas da paz liberal.

O capítulo 3 revisita a produção da historiografia, sobretudo brasileira, sobre o Haitianismo e os impactos da Revolução Haitiana no Brasil escravista. São abordadas as diversas modalidades enunciativas, nem sempre congruentes umas com as outras, que mobilizam estes objetos. Com efeito, é justamente a diversidade de análises e reivindicações do Haiti e do Haitianismo que o capítulo busca evidenciar, a fim de mostrar a pluralidade de escolhas temáticas e agendas de 
pesquisa para as quais podem ser mobilizadas. É proposta uma forma de se tentar organizar os debates e, ao fim, como forma de contribuir para o esforço historiográfico em curso, oferece-se uma gama de fontes primárias ainda não conhecidas pela bibliografia disponível, nas quais o Haiti é mobilizado pelo discurso político brasileiro oitocentista sem, todavia, o emprego direto do conceito de Haitianismo.

No capítulo 4 são analisados os documentos de época que mobilizam textualmente o conceito de Haitianismo. São fontes primárias pesquisadas em periódicos e pasquins do Brasil imperial, assim como nos Anais do Parlamento Brasileiro referentes ao século XIX. É possível observar que seus usos excedem substancialmente as modalidades enunciativas percebidas pela maior parte da literatura sobre o tema. São destacados seis tipos de mobilização discursiva do Haitianismo, de acordo com os objetivos políticos e efeitos de poder produzidos por cada um. Chama a atenção, em todos eles, como a colonialidade e formas de exercício de biopoder faziam-se presentes quando se empregava diretamente o conceito, as técnicas e as práticas políticas do Haitianismo.

No capítulo 5, os discursos brasileiros no âmbito da MINUSTAH recebem uma mirada analítica crítica com ajuda de abordagens decoloniais, pós-coloniais e também as que se centram na questão da governamentalidade. Mais especificamente, são escrutinizadas as narrativas que proclamam existir um inegável 'sucesso' no que se refere à participação brasileira - sobretudo militar na MINUSTAH. Além de fontes acadêmicas, jornalísticas, de Organizações Não Governamentais (ONGs) e de autoridades estatais, com destaque para as burocracias militar e diplomática, também são apresentados os resultados das entrevistas com brasileiros - integrantes ou ligados à MINUSTAH - que foram realizadas durante o trabalho de campo no Haiti, entre janeiro e fevereiro de 2017.

O capítulo 6 desenvolve o argumento central da tese. Partindo das orientações metodológicas de Michel Foucault na Arqueologia do Saber (2016), demonstra-se qual tipo de regularidade discursiva está em operação nos objetos, conceitos, modalidades enunciativas e escolhas temáticas vistas nos capítulos anteriores. Em seguida, é delineada uma genealogia desta formação discursiva, como tática para resistir aos efeitos de poder próprios ao regime de verdade em questão. Tendo em vista que são práticas relacionáveis a partir do jogo entre suas instâncias de emergência e irrupção enquanto acontecimentos discursivos, elabora- 
se, então, uma maneira de tratar a MINUSTAH como Haitianismo. Ao final, é apontado o que se ganha, teórica e politicamente, com esta conceptualização.

À guisa de conclusão, a última parte recapitula os passos dados ao longo desta tese e sugere novas avenidas de investigação que tomem o Haitianismo enquanto dispositivo de poder. Aponta-se as vantagens de assim proceder e indicase algumas problemáticas que podem ser frutiferamente percorridas caso retenhase o devido rigor analítico, assim como um mínimo de coerência normativa, frente aos desafios da colonialidade e do biopoder. 


\section{CAPÍTULO 2: O intervencionismo e seus críticos: a Paz Liberal e o Haiti}

\section{A Paz Liberal nas Relações Internacionais}

Os debates sobre as intervenções internacionais humanitárias do pós-Guerra Fria possuem, nos dias atuais, uma abundante literatura. $\mathrm{O}$ tema abrange desde documentos oficiais e relatórios das agências e organismos envolvidos em tais operações até debates acadêmicos, passando pela não menos volumosa quantidade de reportagens, declarações públicas de sujeitos e objetos de tais intervenções, bibliografia jurídica decorrente das controvérsias por elas geradas, assim como romances, crônicas e novelas inspiradas no contexto político e social ensejado pelos "encontros imperiais" (DOTY, 1996) promovidos por esta frequente prática internacional. ${ }^{7}$

As teorias de Relações Internacionais (RI) naturalmente fazem parte deste cabedal de textos e representações acerca do intervencionismo da chamada Comunidade Internacional sobre espaços no Terceiro Mundo, ou Sul Global, que são discursivamente construídos como necessitados de ajuda externa diante de seu fracasso, falência ou fragilidade (DUFFIELD, 2007; NOGUEIRA, 2017). O tema tornou-se especialmente fértil e capaz de sustentar carreiras acadêmicas exitosas dedicadas exclusivamente ao seu estudo. Roland Paris, ele próprio um exemplo desta tendência, contabilizou um aumento de $350 \%$ no número de artigos em periódicos acadêmicos sobre o tema das operações de paz entre os anos 1980 e 1990. Além da estimativa numérica, o influente autor lembra que foram lançados dois periódicos diferentes sob mesmo título (International Peacekeeping) e que o tema passou a figurar regularmente nas publicações do mainstream de RI, como as revistas World Politics e International Security (PARIS, 2000, p. 27).

No entanto, em inícios dos anos 2000, a percepção de Roland Paris, assim como de outros especialistas no tema, era a de que apesar desta proliferação de

\footnotetext{
${ }^{7}$ No âmbito dos estudos de Relações Internacionais, os trabalhos de Chandler (2002, 2006), Duffield (2001, 2007), Finnemore (1996), Paris (1997, 2000, 2001, 2002, 2010), Richmond (2005, 2007) e Weiss (2007) são referências sobre o tema, que o abordam mediante diferentes perspectivas. Dentre a produção literária ficcional, pode-se mencionar, como exemplo, o livro inspirado pelo controverso episódio de suicídio (ou assassinato), em 7 de janeiro de 2006, do general brasileiro Urano Bacellar, no instante em que ocupava o posto de comandante militar da missão da ONU no Haiti. A obra é do escritor haitiano Gary Victor, conhecido por seu estilo Polar Vodu. Cf. Victor, G. Cures et châtiments. Montreal: Ed. Memoire d'Encrier, 2013.
} 
estudos sobre operações de paz, a maioria dos trabalhos apresentava baixa profundidade teórica e pouco interesse em dialogar com as teorias de RI ou ciência política. O resultado seria aquilo que ele identificou como um "foco pragmático" predominante nesta literatura.

\begin{abstract}
Nevertheless, even though the study of peace operations is burgeoning, it remains largely cut off from the rest of political science. Contributors to this literature have focused primarily on practical, policy-related issues such as the design and conduct of particular missions, rather than building bridges between the study of peace operations and larger theoretical debates in the discipline [of IR]. (PARIS, 2000, p. 27)
\end{abstract}

Tendo em vista tal diagnóstico, é compreensível o clamor por uma ampliação das investigações teóricas sobre operações de paz, tarefa em que ele mesmo se engajou desde então, principalmente no sentido de explorar as conexões entre tais operações e as teorias de RI, assim como "controvérsias teóricas em outros campos que não as RI” (PARIS, 2000, p. 28). É nesta agenda que se deve situar a fase inicial de sua carreira, onde predominavam textos críticos à chamada Paz Liberal, como "Peacebuilding and the Limits of Liberal Internationalism" (1997) ou, mais contundentemente, "International Peacebuilding and the 'mission civilisatrice" (2002).

No entanto, uma década depois de seu próprio chamado, Paris (2010) revela-se desconfortável com a amplitude exagerada, em sua avaliação, que os estudos críticos sobre o tema adquiriram desde então. Em "Saving Liberal Peacebuilding" (2010), Paris realiza uma guinada importante em sua própria trajetória, buscando "salvar" justamente aquilo que ele inicialmente julgava merecedor de críticas mais abrangentes. Este movimento já tinha sido percebido antecipadamente por olhares atentos à evolução dos debates, como o de John Hearthershaw (2008), que entendia a nova posição explicitada por Paris (2010) como paradigmática deste movimento gradual de domesticação da crítica às operações de paz. Uma estratégia que buscaria criar um novo consenso em torno do tema, mas mantendo o peacebuilding consensus descrito por Richmond (2007), preservando-o, assim, de questionamentos mais radicais.

However, this search for a new consensus represents less of a shift away from the liberal peace than the author imagines. Moreover, the manner in which Paris develops his argument serves to regenerate the very hegemonic liberal peace which he seeks to critique and replace. IBL [institutionalisation before liberalisation] is 
an attempt at a revised synthesis which, in terms of both its content and synthesising function, is comparable to the pragmatic peacebuilding texts such as MSW [More Secure World $]^{8}$ and R2P [Responsibility to Protect $]^{9}$. The discursive incorporation which they represent constitutes a further realignment of neo-liberal temporal and spatial conceptions. The attempt to rescue and reform peacebuilding - rather than comprehend it as a functional 'myth' and/or thoroughly reconceptualise it - characterises the moderate criticism of many pragmatists who work directly with the International Community and are oriented toward policy prescription. (HEATHERSHAW, 2008, p. 19)

Desta forma, o caminho percorrido pelos trabalhos de Roland Paris permite captar o percurso que culminou no atual estado dos debates sobre o tema nas RI. Seguindo as proposições mais recentes do autor, pode-se esquematicamente perceber três grandes posições a respeito da paz liberal e seu intervencionismo humanitário contemporâneo: (i) a visão idílica ("irracionalmente exuberante") próliberalização política e econômica como solução universal para sociedades no pósconflito, que dominou o debate entre o começo e meados dos anos 1990; (ii) as críticas moderadas que ganharam força a partir da virada do século e que reconhecem o histórico empírico negativo ou dúbio das operações de paz, levandonos a questionar sua "efetividade e legitimidade", com o intuito de aperfeiçoar tais empreendimentos, teórica e praticamente, sem, no entanto, abandoná-los de vez; e (iii) aquilo que Paris (2010) classifica como postura "hipercrítica", da qual o autor buscar se precaver atualmente, uma vez que dá mostras de "ceticismo infundado e até cinismo", sendo "desautorizadas e imprudentes" em suas denúncias da paz liberal, que precisa, deste modo, ser "salva desta reação adversa exagerada" (2010, p. 338-339). Sobre este último grupo, diz o autor:

But recent years have also witnessed the emergence of what might be called a "hyper-critical" school of scholars and commentators who view liberal peacebuilding as fundamentally destructive or illegitimate. Some of these critics maintain, for example, that the post-conflict operations of the past two decades have done more harm than good. Others go further, portraying these operations as a form of Western or liberal imperialism that seeks to exploit or subjugate the societies hosting the missions. (PARIS, 2010, p. 338)

Não obstante a conversão de uma figura tão emblemática de crítica à paz liberal em direção à defesa das práticas intervencionistas ocidentais, sua

\footnotetext{
${ }^{8}$ UNITED NATIONS. A More Secure World: Our Shared Responsibility. Report of the SecretaryGeneral's High-Level Panel on Threats, Challenges and Change. UN: New York, 2004.

${ }^{9}$ INTERNATIONAL COMMITTEE ON INTERVENTION AND STATE SOVEREIGNTY. Responsibility to Protect. Ottawa: International Development Research Centre, 2001.
} 
argumentação contra aquilo que denomina "escola hipercrítica" é pouco convincente, pois admite sem reservas que não está disposto a considerar proposições "não liberais" ou mesmo "pós-liberais" sobre o tema, aceitando como válidas somente "alternativas dentro da construção da paz liberal" (2010, p. 339 itálico no original). Portanto, apesar de acusar os hipercríticos de escorregarem por "dogmas" que ao fim seriam "apenas uma outra ortodoxia inquestionável”, Paris (2010) é quem sustenta sua argumentação mediante expedientes dogmáticos, ou mesmo sectários, ao vaticinar que "não existe alternativa realista a alguma forma liberal de estratégia de construção da paz" caso queira-se continuar com "a prática de prover assistência em larga escala para sociedades no pós-conflito" (2010, p. 339-340 - itálico no original). Assim, a presente tese se utiliza da classificação proposta por Paris (2010), ao mesmo tempo em que subverte a política de sua taxonomia, ao reivindicar a pertinência de análises hipercríticas sobre o tema em questão. $^{10}$

\section{Neoliberalismo, biopoder, agendas domésticas e colonialidade}

Se toda "teoria é sempre para alguém e para algum propósito" (Cox, 1981, p. 128) é importante situar de qual lugar de fala parte-se para elaborar a presente análise, tanto o quanto interrogar os interesses e agendas políticas das práticas discursivas que se pretende escrutinizar. Sendo assim, o registro que informa a presente investigação situa-se fora do escopo do liberalismo em qualquer de suas versões, clássicas ou neoliberais, uma vez que entende seu "propósito" social no mesmo sentido da teorização crítica descrita por Cox (1981) e Horkheimer (2002). No tema em questão, como parte da resistência ao modo de vida capitalista, à colonialidade do poder (QUIJANO, 2005) e também ao projeto biopolítico da modernidade ocidental (DUFFIELD, 2007; FOUCAULT, 1979). Busca-se resistir especialmente às práticas de controle do Outro não ocidental, não branco, que o intervencionismo liberal afirma querer melhorar, salvar ou proteger, ainda que muitas vezes tal intromissão não tenha sido requisitada ou seja bem-vinda pelas populações e territórios-alvo de tais operações que, sintomaticamente, são autointituladas como missões. Aceita-se, portanto, o rótulo de hipercrítico proposto

10 Para uma resposta enérgica e nominal a Paris (2010), ver Cooper et al. (2011). Para uma estruturação alternativa, ainda que não totalmente distinta, dos debates sobre a construção multilateral da paz, ver Gomes (2013) e Toledo \& Facchini (2017). 
por Paris (2010) em sua tentativa de estigmatizar e desqualificar, mas que pode servir ao desiderato inverso, já que reclama maior rigor teórico e coerência políticonormativa.

Deste modo, assumindo que a crítica radical (que vá à raiz) não seja um problema em si - especialmente para quem não faz da paz liberal uma carreira ${ }^{11}$ é preciso levar a sério as abordagens que ousam questionar frontalmente o paradigma dominante e também suas variantes reformistas. Isto implica em não apenas reconhecer os fracassos da grande maioria das operações de paz no pósGuerra Fria e tratar de aperfeiçoar suas práticas e discursos, contendo a crítica em seus próprios termos e visões de mundo. Mas, isto sim, alterar fundamentalmente os próprios termos do debate em uma direção alheia aos limites da paz liberal. Tal postura hipercrítica faz-se, assim, pertinente, mesmo que requeira coragem para desafiar o poderoso consenso sobre a necessidade de algum tipo de intervencionismo.

Michael Pugh é um dos autores considerados hipercríticos por Paris (2010), devido ao seu engajamento sistemático na tarefa de evidenciar os elos entre o capitalismo global e aquilo que chama de "projeto da paz liberal". Valendo-se da contribuição de pesquisadores afeitos à sua perspectiva, como Craig Murphy (2005), Pugh afirma em "The political economy of peacebuilding: a critical perspective" (2005) que,

In historical terms, then, one can legitimately argue that the liberal peace has been a fluid response to the logic of industrial and post-industrial capitalism (...) The liberal project not only ignores the socio-economic problems confronting war-torn societies, it aggravates the vulnerability of sectors of populations to poverty and does little either to alleviate people's engagement in shadow economies or to give them a say in economic reconstruction.

(...) The hubris of peacebuilders keys the political economy of war-torn societies into a map captioned 'the liberal peace project'; that, in its economic dimension, requires convergence towards 'market liberalisation' (...) without transformation of the IFIS [International Financial Institutions], and the liberal agenda itself, subjugation rather than emancipation will continue to be injected into the political economy of peacebuilding. (2005, p. $23 ; 25 ; 38)$

\footnotetext{
${ }^{11}$ Edward Said menciona a novela Tancredo, de Benjamin Disraeli, e sua famosa afirmação de que “o oriente é uma carreira", salientando que não seria "apenas uma carreira" levada a cabo de maneira instrumental e cínica, mas uma verdadeira "paixão devastadora sobre alguns jovens ocidentais" (SAID, 2003, p. 5). O mesmo pode ser dito sobre as operações de paz atuais, conforme admitido por um jovem diplomata brasileiro, que "também se considera vítima da 'mística orientalista' e da sedução 'salvacionista' dos blue helmets" (NASSER, 2012, p. 213).
} 
Pugh (2005) apresenta uma mirada deveras crítica sobre aquilo que denominou como "ortodoxia agressivamente promovida" durante os anos 1990, centrada na abertura dos mercados e privatizações nas regiões sob intervenção. Analisando episódios e documentos relacionados às intervenções da Organização do Tratado do Atlântico Norte (OTAN) nos Bálcãs, ele enxerga a paz liberal como fundamentalmente destinada a garantir a expansão da "ideologia da globalização" e das "democracias de mercado" para regiões previamente renitentes. Sem poupar a ajuda financeira provida pelos doadores internacionais, este autor acrescenta:

Notoriously, aid often privileges the purchase of donor goods and expertise rather than local products and employment. Privatisation has been pursued at the expense of public goods and public space. ${ }^{12}$

(...) A key aspect of the 'liberal peace' thus promotes a form of economic control and regulation to establish market correctives in societies that have been resistant to conventional marketization imperatives. (PUGH, 2005, p. 23-24; 33)

Argumento similar emana da abordagem neo-gramsciana de Ian Taylor (2010). Em "Liberal Peace, Liberal Imperialism: a Gramscian Critique" (2010) ele reforça as conclusões de Pugh (2005) ao salientar que as sociedades em pós-conflito são alvos oportunos para a imposição de terapias de choque neoliberais (KLEIN, 2007). Após apresentar suas premissas sobre a existência de uma "elite transnacional" cuja visão particular de mundo, "o neoliberalismo", é hegemonicamente apresentada como universal (TAYLOR, 2010, p. 155-156), o autor enfatiza uma posição inequivocamente contrária a tal agenda. ${ }^{13}$

Taylor (2010) cita como exemplos desta lógica os discursos de exsecretários-gerais da ONU, como Boutros Boutros-Ghali e Kofi Annan ${ }^{14}$, concluindo que a agenda atualmente perseguida pelos principais atores envolvidos

\footnotetext{
${ }^{12}$ Argumento bastante similar é feito por Seguy (2015) com relação ao papel das ONGs e demais agências humanitárias empenhadas na reconstrução do Haiti após o terremoto de 2010.

${ }^{13}$ Ele vaticina: "The whole point of the liberal peace is to construct the institutional framework that will allow the private sector to 'deliver' and work its magic in post-conflict societies" (TAYLOR, 2010, p. 159).

14 "In today's world, the private sector is the dominant engine of growth; the principal creator of value and wealth; the source of the largest financial, technological, and managerial resources. If the private sector does not deliver economic and economic opportunity (sic.) - equitably and sustainably - around the world, then peace will remain fragile and social justice a distant dream" (ANNAN, 1997 citado por TAYLOR, 2010, p. 158-159). O discurso de Kofi Annan ao Fórum Econômico Mundial em Davos, 1997, é de fato ilustrativo desta postura. Após afirmar que o elo entre as Nações Unidas e o setor privado é "vitalmente importante", ressaltando que o "capitalismo de mercado não possui nenhum grande rival ideológico", ele clama pelo "reforço" da parceria entre a ONU, governos e a "comunidade corporativa internacional". Ver a íntegra do discurso em (acesso em maio de 2018): https://www.un.org/press/en/1997/19970131.sgsm6153.html.
} 
com a construção multilateral da paz baseia-se na noção de que a introdução de reformas em direção ao livre-mercado e a adoção de um modelo liberal de democracia seriam os grandes facilitadores da paz em situações de pós-conflito. Além de discordar de tal premissa, ele denuncia os mecanismos de silenciamento e desqualificação de alternativas, incluindo neste ponto uma forte crítica ao papel desempenhado pelo mundo acadêmico também:

In many respects, it is the quantity of advice and the message that is given within a particular remit from a particular epistemic community that count, as well as the negative shaping of what is not possible. (...) A vast array of agents (including the IMF, the World Bank, WTO, OECD, and regional development banks, influential think-tanks and foundations) all either directly fund post-conflict 'rebuilding' or, via academic actors, fund 'research' which arrives at the conclusion that more liberalism in the economic and political realm is what the world needs, particularly if in a post-conflict situation. (Tay|Lor, 2010, p. 164; 167; 168 - itálico no original)

A crítica ao neoliberalismo constitutivo das operações de paz não é exclusiva deste tipo de abordagem, que privilegia o aspecto econômico. Há um importante número de pesquisadores em RI seguindo o legado de Michel Foucault e sua crítica filosófica aos modos de exercício do poder e que, portanto, observam o neoliberalismo sobretudo como um dispositivo de controle. Mark Duffield, por exemplo, é um pesquisador atento às práticas discursivas das intervenções humanitárias no pós-Guerra Fria. Seu olhar crítico sobre conceitos como segurança humana, central nas narrativas intervencionistas contemporâneas, é crescentemente informado por leituras foucaultianas sobre o tema, o que lhe permite tratá-lo como "uma tecnologia de governança internacional" (DUFFIELD, 2005, p. 3). Este conceito representaria o conhecido nexo entre segurança e desenvolvimento, permitindo às instituições internacionais exercer um poder disciplinar sobre indivíduos e também de tipo biopolítico sobre populações do Sul global. Duffield $(2005,2007)$ percebe que o giro nos objetos-referentes dos discursos da segurança internacional - do estado para as pessoas, daí a segurança humana - não deve ser encarado como emancipatório ou progressista, uma vez que constrói sujeitos "não seguros" (non-insured) que, por sua vez, precisam da intervenção externa para que sua vida coletiva seja promovida, melhorada ou tornada resiliente frente aos imprevistos e inseguranças típicas do mundo chamado de subdesenvolvido. ${ }^{15}$

\footnotetext{
${ }^{15} \mathrm{O}$ autor prossegue: "Within the various assumptions and practices that constitute 'development' it is possible to recognise a biopolitics of life operating at the international level. That is, those varied economic, educational, health and political interventions aimed at improving the resilience and well-
} 
É por isto que Duffield (2005, p. 17) questiona se, ao fim, tais mecanismos não estariam sinalizando o advento de uma "tirania biopolítica global”, assumindo com isto toda a radicalidade de seu enfrentamento à paz liberal. Tal conclusão devese à constatação de que narrativas que alardeiam um constante estado de emergência na segurança humana exigem, como contraparte, intervenções humanitárias permanentes. Ou seja, uma guerra sem fim (Unending Wars, 2007) em nome das pessoas e modos de vida que são apresentados como estando sempre em situação de risco, fragilidade ou necessitados de melhorias nas áreas econômica, educacional, de saúde ou política. ${ }^{16}$

Nehal Bhuta (2008) também recorre a uma análise foucaultiana para desenvolver sua crítica frontal ao projeto da paz liberal. Em Against State-Building (2008, p. 521), ele situa este projeto na mesma linhagem de "modos de pensamento político" como o racionalismo dos reformistas liberais do Império Britânico no século XIX ou as teorias da modernização de meados do século XX. Junto com os atuais discursos sobre "boa governança" e "transição democrática" emanados do Novo Institucionalismo da ciência política norte-americana, tais narrativas compartilham de uma aspiração comum a realizar uma "engenharia de sujeitos humanos", que precisam ser tornados "objetos de conhecimento, medição, calibragem" e também passiveis de serem "refeitos em nome do telos da ordem

\footnotetext{
being of people whose existence is defined by the contingencies of 'underdevelopment'. While development programmes contains individualising disciplinary elements, typically in the form of projects, they also seek to strengthen the resilience of collectivities and populations. Towards this end, development draws widely on regulatory mechanisms, risk management techniques and compensatory programmes that act at the aggregate level of economic and social life. In particular, development is a biopolitical security mechanism associated with populations understood as essentially self-reproducing in relation to their basic social and welfare needs" (DUFFIELD, 2005, p. 6).

${ }^{16}$ Linha argumentativa similar é seguida por Dillon e Reid (2009). Em uma resenha comparativa entre os dois trabalhos de maior vulto de Mark Duffield - "Global Governance and the New Wars" (2001) e "Development, Securty and Unending Wars" (2007), um comentador inicialmente simpático à sua abordagem, David Chandler, resume de maneira didática o argumento foucaultiano empregado neste tipo de crítica à paz liberal: "Human security, under the aegis of the 'human' offers a divisive vision of the world, where the west has both a security 'interest' and a 'values-based' desire to 'secure', to 'develop', to 'protect' and to 'better' the Other, whose insecurity threatens the security of Western consumer society as the instabilities associated with conflict, poverty, and alienation threaten to spill over into and to destabilise the West. The desire to contain instability is understood as the need to address the threatening unmet needs of the unsecured, uninsured and insecure non-Western Other. Since the development solution of self-reliance and sustainable development does not offer to bridge the development gap with the West but instead to contain it, the limitations of self-reliance are continually coming to the fore, promising an unending war where interventionist development techniques are continually being reinvented and perfected" (CHANDLER, 2008, p. 269).
} 
normativa consagrada" (BHUTA, 2008, p. 518). Para ele, trata-se de "tecnologias de intervenção política" que revelam uma "ideologia da tutela" (2008, p. 528-529).

\begin{abstract}
Many of the trappings of nineteenth century rationalism - its naïve naturalism, its crude teleology, and often explicitly racialized hierarchies of social and political organization - are no longer with us. But despite this, the conceptual grammar and syntax of politics as technology remains fundamentally constitutive of disciplines such as economic development and, I would suggest, the emergent knowledgecomplex of state-building and democratization. These modes of political thinking are not merely ideas or representations to be corrected or adjusted. They are modes of political being that are codified, operationalized and disseminated through a variety of circuits: financial, academic, non-governmental. They are, in other words, quintessentially forms of knowledge/power in the Foucauldian sense, which actively envision, shape and discipline political subjectivities in creating new modes and orders. Almost two decades since the end of the Cold War, categories such as democratization, good governance and now, state-building, have emerged not only as normative ideals, but forms of expertise characteristic of politics-astechnology. (BHUTA, 2008, p. 521)
\end{abstract}

O grande problema, para Bhuta (2008), é que tais discursos universalizantes tendem a criar "técnicas de pensamento" que homogeneízam o espaço político e social de outras sociedades (não ocidentais), gerando "objetos-artefatos de saber" que, segundo o discurso da paz liberal, precisam ser melhorados por uma intervenção externa que lhes traga maior racionalidade. Ignora-se, assim, a história particular e as topografias políticas próprias dos territórios que serão alvo da intervenção. A afinidade em comum entre tais técnicas, segundo o autor, seria de caráter epistemológico, uma vez que é o "movimento conceitual" de reduzir as diferentes realidades locais à "variáveis", "fatores", "tipos” ou mesmo "culturas", que está na raiz deste tipo de autoautorização para intervir (BHUTA, 2008, p. 532).

Embora filiando-se à linhagem hipercrítica de análise dos discursos da $p a z$ liberal, John Heathershaw (2008) chama atenção para alguns riscos envolvidos nesta tarefa, em especial o de se tratar os próprios discursos intervencionistas como se fossem monolíticos. Para ele, há uma relação intertextual entre três modos narrativos distintos, que operam dentro do ambiente discursivo em questão, a saber: (i) democratic peacebuilding; (ii) civil society peacebuilding; e (iii) statebuilding. Tomados em conjunto, eles constituem um "imaginário holístico" que permite a implementação de um quarto modo, fruto da fusão dos três anteriores em um "metadiscurso", que ele classifica como pragmatic peacebuilding. Este discurso seria capaz de servir para intervenções internacionais sem limites, já que aplicados a partir de uma “ordem mundial virtual” (HEATHERSHAW, 2008, p. 597-599). Sem 
uma compreensão destas "inscrições competitivas" trinitárias, argumenta, não é possível captar adequadamente a "forma de governamentalidade" das operações de construção da paz, "where ethical, spatial and temporal shift markers inconsistently under a hybrid liberal-conservative-humanitarian mode of hegemonic governance" (HEATHERSHAW, 2008, p. 621).

Além disto, ele também alerta para o que considera como outro "erro analítico" da literatura crítica sobre o tema: tratar o discurso da construção liberal da paz como conscientemente hipócrita, que mal disfarçaria as verdadeiras intenções dos atores internacionais envolvidos. Segundo Heathershaw, poucos “peacebuilders" são de fato cínicos, assim como poucos deles veriam a si próprios como representantes do braço armado de um poder imperial. Ao contrário, o problema é que a maioria possui um fervor "evangélico" e genuinamente "internacionalista" na sua entrega ao trabalho, mesmo que isto termine por reproduzir a fronteira entre $E u$ e o Outro durante a tarefa de transformar os Outros naquilo que Nós imaginamos ser (HEATHERSHAW, 2008, p. 602). ${ }^{17}$

Suas conclusões e os corolários delas decorrentes, no entanto, não suavizam o espírito crítico de sua contribuição. Heathershaw (2008) sugere que a construção liberal da paz é "imperial” pois intenta reabilitar um alto grau de intervencionismo internacional, "ausente desde o declínio do colonialismo após a Segunda Guerra Mundial” (2005, p. 621). Ele recorda da admissão pública deste ponto feita por Michael Ignatieff em 2002, um expoente na defensa do intervencionismo humanitário.

Imperialism used to be the White man's burden. This gave it a bad reputation. But imperialism doesn't stop being necessary just because it becomes politically incorrect. Nations sometimes fail, and when they do outside help - imperial power - can get them back on their feet. Nation-building is the kind of imperialism you get in a human rights era, a time when great powers believe simultaneously in the right of small nations to govern themselves and their own right to rule the world. (IGNATIEFFL, 2002 citado por HEATHERSHAW, 2008, p. 19) ${ }^{18}$

17 Como visto anteriormente, esta percepção é compartilhada por Said (2003) acerca do Orientalismo e também por Nasser (2012) com relação às operações da paz liberal, em artigo sobre a participação de brasileiros na MINUSTAH.

18 A íntegra do artigo de Michael Ignatieff pode ser lida em (acesso em maio de 2018): https://www.nytimes.com/2002/07/28/magazine/nation-building-lite.html.

Além disto, Heathershaw (2008) também reforça que se trata de uma prática destinada a fracassar frente aos seus próprios objetivos, já que busca produzir uma "paz virtual": algo mais visível para observadores de fora da zona de conflito, situados na "comunidade internacional liberal", do que para aqueles sobre os quais esta paz está sendo trazida. E, por fim, que ao representar a inclusão concomitante da ideia de paz e da prática da guerra, termina hoje sendo um processo cujo término é 
David Chandler, por sua vez, adota uma postura igualmente crítica em uma série de artigos e livros que, em geral, são mais interessados em formular, criativamente, hipóteses próprias sobre a paz liberal do que encaixá-la em algum referencial teórico pré-estabelecido, expediente que ele critica em Duffield (2007) e sua ênfase no enquadramento foucaultiano (CHANDLER, 2008, p. 271-272). Um argumento frequente em suas obras é o de que as intervenções humanitárias servem para atender a objetivos domésticos das elites ocidentais relacionados à sua perda de contato e legitimidade junto a seus respectivos eleitorados (CHANDLER, 2002; 2006). Dada a falta de projeto de sociedade e visões mobilizadoras, tais elites empreenderiam uma política externa moralista ou ética, com o intuito de negar seu próprio poder e sua responsabilidade perante a manutenção de más condições de vida no ocidente e, principalmente, fora dele. Em "From Kosovo to Kabul and Beyond: Human Rights and International Intervention" (2002) ele explica assim sua proposição:

The search for rebuilding connections between the government and society has driven Western governments to attempt to define themselves through taking the moral high ground and this process has led to a more active foreign policy. Foreign policy has become increasingly important to the domestic agenda as an area in which governments and leading politicians are more likely to be able to present themselves as having a sense of purpose or 'mission'. Ethical foreign policy also enables Western leaders to appear to be directly representing the moral concerns of people regardless of political affiliation. This is possible because foreign intervention does not impact directly on the electorate's immediate concerns, avoiding the problem of direct accountability and creating a sense of national-unity around a moral platform. (2002, p. 221)

No entanto, para Chandler esta tentativa tem poucas chances de funcionar, uma vez que é um expediente despolitizante que, portanto, "não consegue criar estabilidade nem oferecer uma visão construtiva do futuro" (2002, p. 236). Ao apelar para as "práticas de evasão" de responsabilidades, as lideranças ocidentais tentam negar seu próprio poder e transferir a culpa pelo fracasso das intervenções para atores locais, ao mesmo tempo em que buscam impedir que projetos de sociedade alternativos floresçam em seus próprios países, garantindo assim que soluções administrativas ou técnicas para problemas políticos sejam vistas sempre

indeterminado, pois “dura por muitas gerações e cujo final é raramente ou nunca definido" (2008, p. 621). 
como a melhor opção. No famoso livro "Empire in Denial: the Politics of Statebuilding" (2006), ele aprofunda este ponto, naquilo que pode ser lido como ceticismo frente à admissão pública feita por Ignatieff (2002) sobre o tema, mencionada acima: "State-building is the practice of denying empire" (CHANDLER, 2006, p. 190). Mesmo quando admite reconhecê-lo, poder-se-ia acrescentar.

Empire is drawn by the weakness of non-Western states, in the same way that nature abhors a vacuum, and empire is happy to make grand rethorical statements of Western mission and sometimes to intervene coercively in the search for a sense of political purpose (see LAÏDI, 1998; CHANDLER 2003). Yet, as soon as policy action or intervention is undertaken, and costs have to be justified by justifications of political ends, denial becomes a central concern and policy practices attempt to shift responsibility and accountability onto the non-Western state itself. This process of assertion of power and its denial sets up the contradictory dynamic of state-building, which is both highly interventionist and highly evasive. (2006, p. 190)

Por fim, a paz liberal também se tornou objeto da crítica pós-colonial e, mais contundentemente, fonte de reflexões para intelectuais identificados com o paradigma decolonial, como é o caso de Meera Sabaratnam (2013). Inspirada por autores como Aníbal Quijano (2000) e Walter Mignolo (2000), ela estabelece um diálogo respeitoso com outros autores hipercríticos sem, no entanto, deixar de alertar sobre os Avatares de Eurocentrismo presentes nas suas próprias abordagens críticas à paz liberal. Seu intuito, portanto, é aumentar a profundidade da crítica a partir do questionamento dos seus limites de imaginação política, que terminam por "fechar, em vez de abrir, modos contra-hegemônicos de pensar o internacional" (SABARATNAM, 2013, p. 260). Embora reconhecendo que haja uma "ética póscolonial", ou "ethos anti-imperial", nesta literatura crítica, Sabaratnam (2013, p. 260) acredita que os procedimentos analíticos podem, e devem, ser ainda mais descolonizados. Ela identifica quatro tipos de avatares de eurocentrismo frequentes na literatura crítica sobre paz liberal, derivados dos três casos típicos encontrados nas ciências sociais em geral:

The critical debate on the liberal peace is haunted by four particular avatars of Eurocentrism, which extend from the categories above: a methodological bypassing of target subjects in empirical research; the analytic bypassing of subjects in frameworks of governmentality; an ontology of cultural Otherness via the 'liberal'/'local' divide; and critical nostalgia for the liberal social contract, a liberal subject and European social democracy. These collectively constitute a 'paradox of liberalism' in which Western liberalism is seen as a source of 
oppression but also implicitly understood as the only true source of emancipation. (2013, p. 263)

Ela sugere que se deve "descolonizar a mirada analítica" (2013, p. 263) a fim de não reproduzir, mesmo que sutilmente, tais expedientes eurocêntricos. Três estratégias intelectuais podem ajudar nesta tarefa, que a autora admite ser “desorientadora" pessoal e psicologicamente, além de não totalmente alcançável, nem por ela mesma, devido ao poder de "sedimentação do saber eurocêntrico que chega até o coração da prática acadêmica profissional” (2013, p. 274). A primeira estratégia seria recuperar a presença política e histórica das sociedades-alvo, diminuindo as chances de se postular uma hiperagência dos interventores ocidentais em detrimento de uma pequena ou nula agência de quem sofre as intervenções. Este seria o principal problema de análises críticas como as de Duffield $(2005,2007)$ e Chandler (2002, 2006), vistas acima. ${ }^{19}$

A segunda estratégia seria evitar os discursos baseados em diferenças culturais, que replicam ontologias de racismo e civilização (BALIBAR, 1991), para repolitizar as distinções e hierarquias criadas pelas intervenções mediante conceitos como diferença colonial (MIGNOLO, 2000) e colonialidade do poder (QUIJANO, 2000), que mudam o foco do encontro com uma cultura alheia (ocidental) para os processos alienantes que estão acontecendo durante este encontro neocolonial: "deslocamentos, violência, silenciamento, humilhações e espoliações" (SABARATNAM, 2013, p. 272). A terceira estratégia diria respeito à descolonização da crítica da economia-política da paz liberal ao estilo de Pugh (2005) e Taylor (2010), de modo a sair das análises meramente estruturais em direção a abarcar as experiências e interpretações feitas pelos sujeitos políticos que sofrem os efeitos materiais das intervenções. Este passo ajudaria a politizar as várias formas de privilégios de propriedade, espoliações e acumulações, evitando, assim, cair na retórica nostálgica de um Estado de bem-estar social ao estilo europeu ou, pior ainda, na linguagem do desenvolvimento, "amplamente reconhecida como

\footnotetext{
19 "In this sense, Duffield's account of intervention is not dissimilar to Chandler's, in that they both focus on the agency and subjecthood of interveners, even if under the analytic of governmentality this becomes more diffuse. Yet, they both exclude and avoid considerations of the exteriority of this power, and particularly the peoples targeted by interventions as political subjects. The habit of methodological exclusion noted in the previous section becomes then cognate with the analytic exclusions that underpin the framework of governmentality. Both exhibit avatars of Eurocentrism, which emphasize the distinctiveness and importance of Western behavior while occluding the space outside it" (SABARATNAM, 2013, p. 266).
} 
uma abordagem colonial e despolitizante para temas como política econômica e pobreza" (SABARATNAM, 2013, p. 273-274).

Ao fim, Sabaratnam clama por uma acentuação da crítica à paz liberal ou, em seus termos, uma “descolonização" da própria crítica (2013, p. 270). O principal aspecto a ser trabalhado, na opinião da autora, é a reprodução implícita de uma certa unicidade ontológica excepcional conferida ao ocidente, que geralmente é apresentado como um dado em si mesmo, endógena e autonomamente constituído (junto com sua modernidade) e que estaria expandindo sua fronteira colonial desde a época dos impérios ultramarinos europeus até as atuais práticas intervencionistas humanitárias. Para fugir dos "enquadramentos filosóficos do eurocentrismo", ela clama por mais radicalidade na crítica:

This means that a radical critique of the liberal peace ultimately requires a more radical disruption of its Eurocentric epistemic underpinnings, as well as a repoliticization of that sensibility of Western distinctiveness that is taken as an ontological 'given'. Mignolo and Quijano remind us that this kind of project - a decolonial or decolonizing project - must begin through a re-engagement with that which Eurocentric thinking suppresses or discounts; for us, this is that which is exterior to the presumption of Western distinctiveness. This does not mean that which is untouched by colonial-modern forms of rule and knowledges - after all, the point is that there are hardly any such geographic spaces. It means that which locates or relocates itself epistemically and methodologically at the boundaries of the colonial-modern, finding different political sites from which to think about the world and constructing different problematiques for analysing it. (2013, p. 270)

Abordagens mais recentes buscam oferecer modos inovadores de se analisar o intervencionismo sem recair nos deslizes alertados por Sabaratnam (2013), mesmo que persistam na tentativa de aplicar o instrumental teórico foucaultiano ao tema em questão. Como exemplo, há contribuições de Sam Opondo que têm êxito nesta empreitada. Além de enfatizar a fala dos subalterizados em artigo conjunto com Michael Shapiro (2018), este autor avançou na ampliação do conceito de biopolítica para os planos internacional e global de maneira que dialoga, mas não se restringe às análises de Duffield $(2005,2007)$ ou mesmo aos trabalhos contidos na compilação de Wendy Larner e Willian Walters sobre Governamentalidade Global (2004).

Em trabalho conjunto com Costas Constantinou intitulado Engaging the 'ungoverned': the merging of diplomacy, defence and development (2016), há uma reflexão sobre fenômenos recentes como a militarização da diplomacia e a diplomatização das intervenções militares, especialmente em territórios tidos como 
subdesenvolvidos, ou desgovernados. Tais aparatos diplomático-militares, segundo os autores, representariam "uma mudança ontológica da biopolítica para a biodiplomacia" (CONSTANTINOU; OPONDO, 2016, p. 308), abrindo, desta forma, uma nova seara de explorações conceituais que será útil à presente investigação sobre a MINUSTAH, dado que captura com destreza elementos cruciais dos discursos simpáticos à presença brasileira nesta força de ocupação, tanto na literatura especializada, quanto nas entrevistas de campo realizadas pelo autor no Haiti em 2017, discutidas no capítulo 5.

Ainda que este apanhado de abordagens não esgote o cabedal de contribuições hipercríticas formuladas sobre o tema, ele já fornece elementos suficientes para situar a presente tese no quadro geral dos debates sobre o tema da paz liberal nas RI, além de destacar autores cujos trabalhos serão úteis e oportunamente recuperados ao longo desta investigação. Suas contribuições nem sempre se harmonizam totalmente entre si a ponto de poderem ser chamadas de "escola hipercrítica", conforme feito por Paris (2010, p. 338). Mas também é verdade que certos temas comuns são frequentemente invocados por esta vertente da literatura, como aqueles referentes ao neoliberalismo como projeto econômico e de controle; à governança sobre populações e territórios ocupados pelas intervenções; às agendas domésticas que tais operações ajudariam a avançar; além de críticas à atitude colonial, imperial ou imperialista que esta prática representaria - em outras palavras, ao eurocentrismo e à colonialidade do poder (QUIJANO, 2005) que informaria as intervenções humanitárias atuais.

Desta forma, tais abordagens serão úteis no decorrer da presente exploração crítica da paz liberal em sua maior expressão na América Latina e Caribe, que envolveu a formulação extensiva de discursos brasileiros sobre Haiti, ou seja, no âmbito do envolvimento do Brasil com a Missão das Nações Unidas para Estabilização do Haiti (MINUSTAH).

\section{A Paz Híbrida nas Relações Internacionais}

Antes de revisar a literatura crítica que trata especificamente da MINUSTAH, é conveniente dedicar uma breve seção à apresentação de uma vertente relativamente nova nos estudos sobre intervenções humanitárias e operações de paz, que é de grande relevância para o argumento avançado nesta tese. Trata-se daquilo que convencionou-se chamar de Paz Híbrida ou virada local. A 
classificação proposta por Paris (2010) não a engloba, pois surgiria com mais força somente após seu texto ser publicado. Mas é possível concebê-la como uma espécie de via-média que transita entre as críticas moderadas e as hipercríticas. Segundo Aureo de Toledo Gomes (2013), são trabalhos “que advogam a ideia de uma paz pós-liberal", uma vez que "procuram destacar a capacidade de agência da população local e como a mesma negocia, resiste ou mesmo subverte o projeto liberal de reconstrução pós-conflito" (2013, p. 64). Outro comentador ressalta que "são abordagens que acomodam tanto o liberal quanto 'o local' e assim produzem uma forma de paz híbrida" (ANAM, 2015, p. 38-39).

Haveria uma primeira geração de estudos da Paz Híbrida, representada por certo foco pragmático na resolução de conflitos e simbolizada pela figura de John Paul Lederach, conhecido negociador internacional cuja carreira neste campo se iniciara a partir de sua experiência de trabalho com organizações religiosas (GOMES; FACCHINI, 2017, p. 157). No entanto, é a chamada "segunda virada local", iniciada por volta dos anos 2000, que mais interessa à presente discussão, já que são os autores identificados com ela que propõem o conceito de hibridismo como "lente analítica para a investigação de processos de construção da paz" (2017, p. 164-165). Esta abordagem vem ganhando adeptos nos últimos anos e aumentando sua influência no campo de estudos sobre intervenções, ainda que não se possa falar de uma escola de pensamento homogênea e consolidada, pois o conceito tem sido utilizado em diferentes modalidades de análise. ${ }^{20}$

Expoentes da proposta de Paz Híbrida, como Oliver Richmond e Audra Mitchell (2012) e Roger Mac Ginty (2011) vêm produzindo e estimulando uma série de estudos nesta direção, combinando esta inovação conceitual com estudos de caso. Seus proponentes informam que o conceito de hibridismo foi tomado de empréstimo da biologia e horticultura, sendo posteriormente adotado por diversos campos das ciências sociais, como antropologia, sociologia, literatura e estudos pós-coloniais. Tal emprego, no entanto, não foi desprovido de controvérsias.

It has long been used to show how the weak become compliant with hegemonic powers in various, often abrasive, ways, implying in post-colonial terms,

\footnotetext{
${ }^{20}$ Conforme alertado por um autor que escrutiniza esta linhagem: "In literatures discussing Idea of hybrid peace approaches, the concept has been used in several different terms such as 'hybrid peace governance', 'hybrid political orders', 'hybrid peace ownership', and 'local-liberal hybridity'. Each term reflects scholar's main emphasis on how to understand the concept of hybrid peace and on how the hybrid peace approach works in post-conflict peacebuilding" (ANAM, 2015, p. 41).
} 
trusteeship and native administration. A number of authors have been suspicious of the concept, fearful that the notion of grafting one plant on another, or breeding two species to produce a hybrid, was suggestive of binaries and thus too simplistic for complex social-political dynamics. There were also fears that the term was too close to biological determinism and connotations of racism and miscegenation, and that it justified forms of exploitation associated with colonialism or eurocentricism. (MAC GINTY; RICHMOND, 2015, p. 3)

Não obstante tais reticências, estes e outros autores acreditam ser possível lançar mão de uma "visão pós-biológica do hibridismo", que deixe de ser simplesmente uma "apologia ao poder, eurocentrismo e injustiça (2015, p. 3). Para tanto, invocam as referências Néstor García Canclini (2005) e Homi Bhabha (2004), na tentativa de filiarem-se ao pensamento decolonial e pós-colonial, respectivamente. A virada local da Paz Híbrida teria o potencial de superar as piores características da paz liberal ao renunciar ao objetivo de imposição de um modelo político e econômico elaborado previamente pelos interventores. Seria, assim, mais atenta às dinâmicas locais e respeitosa das contribuições que a cultura das sociedades-alvo pode trazer para os intentos de construção da paz, incluindo os mecanismos tradicionais de resolução de conflitos que os agentes locais podem aportar. Tal incorporação, que não abandona o papel dos interventores, mas mesclase a eles, produzira o hibridismo capaz de lograr uma paz mais robusta.

Embora considerem-se opositores da paz liberal, as propostas da Paz Híbrida são - com o perdão do pleonasmo - realmente híbridas, já que não necessariamente renegam o paradigma dominante. Em outras palavras, podem chegar a ser de fato pós-liberais, mas não necessariamente antiliberais. Há momentos, portanto, em que pode-se considerar suas contribuições como hipercríticas. Entretanto, também é possível perceber suas contribuições como mais próximas das críticas moderadas ou reformistas, que visam aprimorar - sem abrir mão - do intervencionismo e até mesmo de alguma forma de governamentalidade (ou seja, de poder) sobre populações locais, geralmente reificadas por este tipo de análise. $^{21}$

\footnotetext{
${ }^{21}$ Os autores afirmam peremptoriamente a possibilidade deste tipo de exercício do poder ser apropriado: "Contextualized, anarchic and evolutionary forms of hybrid political order are to be welcomed insofar as they denote agency among local actors, and a greater self-awareness among interveners who work on their behalf. They are political systems that find equilibrium through longterm processes of negotiation and signaling often at the local level. Potentially, they represent forms of peace and governmentality that are appropriate to local aspirations and needs" (MAC GINTY; RICHMOND, 2015, p. 15).
} 
$\mathrm{Na}$ opinião de alguns autores hipercríticos, tais posturas colocam a $\mathrm{Paz}$ Híbrida em xeque, na medida em que a divisão ocidental vs. local, ainda que hibridizada, reforçaria ontologias da alteridade típicas da paz liberal e de outras formas de colonialidade do saber. Meera Sabaratnam (2013) dialoga diretamente com esta "quarta geração" de estudos sobre intervenções, chamando atenção justamente para esta prática discursiva e os riscos nela envolvidos (2013, p. 266268).

Yet, the paths it has taken have, quite unwillingly, reinforced a Eurocentric understanding of intervention, through the use of an ontology of 'Otherness' to frame the issues (...) The very conception of the 'post-liberal' peace is thus about the ways in which two ontologically distinct elements - the 'liberal' and the 'local' - are rescued and reunited via forms of hybridity and empathy, in which 'everyday local agencies, rights, needs, custom and kinship are recognized as discursive "webs of meaning" (Richmond, 2010: 668) (...) There is a clear emphasis here on the need to engage with the 'indigenous' or 'authentic' traditions of non-Western life, which seems to reflect an underlying assumption of cultural difference as the primary division between these two parties. This reproduces the division between the liberal, rational, modern West and a culturally distinct space of the 'local' (...) The point here is not simply that there is an account of alterity or cultural difference within the politics of intervention, but that the liberal/local distinction appears to be the central ontological fulcrum upon which the rest of the political and ethical problems sit (...) While Mac Ginty does not pursue the ethics of the post-liberal peace in the same way as Richmond, the underlying intellectual framework also uses this distinction as the analytic pivot of the research. (SABARATNAM, 2013, p. 266-267 - itálico no original)

Ciente de tais problemas, Mac Ginty e Richmond (2015) dedicaram-se a tarefa de reformular e sofisticar sua abordagem, passando a criticarem, eles mesmos, a maioria da produção acadêmica sobre Paz Híbrida que lhes sucedeu. Mesmo sendo uma tentativa de salvar aquilo que chamam de "virada híbrida" do mau uso que tem sido feito dela, os autores avisam que o objetivo de se construir instrumentalmente ordenamentos políticos híbridos não passaria de uma "falácia" (2015, p. 1). Diante de tal constatação, eles propõem uma distinção entre o que seria uma Paz Híbrida "negativa", aquela que defende as estruturas de poder do status quo, versus uma paz híbrida "positiva", que é emancipatória e progressista (2015, p. 12-15). Sua argumentação, no entanto, precisa afastar-se dos casos concretos em nome de uma utopia cuja demonstração empírica ainda estaria por vir, tendo em vista que a aplicação da proposta tem recaído na falácia que buscam denunciar. $\mathrm{O}$ resultado é a admissão de que, nesta altura, a proposta de uma Paz Híbrida que seja "socialmente justa" e "resolva os dilemas de circulação do poder" ainda se apoia 
em "projeções abstratas", a fim de escapar da "instrumentalização do hibridismo a serviço de uma paz liberal repaginada" (2015, p. 11-12). ${ }^{22}$

Este parece ser justamente o problema com as tentativas de se empregar o instrumental teórico e político da Paz Híbrida para o caso da MINUSTAH. Ândrei Clauhs (2013) opera de forma extrema esta instrumentalização do hibridismo no intuito de defender a melhor adequação dos militares brasileiros - devida a sua formação multiétnica - para a tarefa de estabilização do Haiti. Seu trabalho será analisado com atenção nos capítulos 5 e 6 desta tese, pois representa paradigmaticamente os perigos envolvidos na defesa e refinamento tático do intervencionismo militar mediante abordagens inspiradas pela virada local, que terminam, em muitos casos, representando posturas "neocoloniais" e "mantendo a existência de relações de poder desiguais" (ANAM, 2015, p. 40).

Pois ao contrário do percebido pelos que advogam esta inovadora abordagem, o maior risco não reside unicamente na romantização da agência local, como frequentemente alertado pela literatura que trata da Paz Híbrida (ANAM, 2015, p. 44; GOMES, 2013, p. 64; GOMES; FACCHINI, 2017, p. 156; MAC GINTY, 2011, p. 68; MITCHELL; RICHMOND, 2011, p. 19). A questão mais grave desta abordagem, isto sim, consiste na romantização da agência dos próprios interventores, como mostra o trabalho de Clauhs (2013) e também versões mais sofisticadas sobre a atuação brasileira na MINUSTAH, como a de Moreno et al. (2012), conforme será visto na próxima seção, que trata das críticas - moderadas, híbridas e hipercríticas - a esta missão da ONU em particular, assim como no capítulo 6, que sugere perceber a MINUSTAH como uma expressão de Haitianismo.

\footnotetext{
${ }^{22}$ Este risco já havia sido antecipado por Heathershaw (2012), que por vezes se aproxima das abordagens da Paz Híbrida, mas buscando manter seu espírito crítico em alerta contra a função legitimadora do intervencionismo que esta proposta pode servir. "It fails to explain how the formal model of peacebuilding survives and is deemed a partial 'success' despite its significant adaptation in practice, and why the increasing academic consensus that peacebuilding is a process of hybridization, variously understood, does not seem to force a reappraisal of the model. The reason for this analytical lacuna may be found in the 'natural' conclusion that emerges from the diagnosis of hybridity shared by many apologists for and critics of liberal peacebuilding. This conclusion is that hybridity indicates merely the partial achievement of the goals of peacebuilding, and thus it leads to the other conclusion that more resources should be expended, or else expectations should be reduced (...) For a hybrid peace to continue to function with its payoffs to both local and international participants, it requires technologies that serve to conceal the political story of hybridity (unacceptable to donors and recipients alike) in favour of an apolitical story of uniformity (a technocratic model that varies in context but retains an essential and universal form) (2012, p. 162-163)
} 
Cumpre notar, por fim, que o hibridismo possui diversas acepções e pode ser mobilizado para múltiplas agendas intelectuais e políticas, não necessariamente convergentes umas com as outras. ${ }^{23}$ Para fins da presente investigação, o que parece de suma importância é dar-se conta que ele tem sido empregado para dar novo fôlego e assim promover a continuidade das práticas intervencionistas também sob retórica pós-colonial, em vez de servir aos propósitos da "gramática da descolonização", que visa de romper decisivamente com a "lógica da colonialidade" e, para tanto, exige que se esteja "desconectando" (delinking) do projeto da modernidade/colonialidade sem tergiversações (MIGNOLO, 2007, p. 449).

\section{MINUSTAH e as críticas acadêmicas à intervenção no Haiti}

Dentro do debate acadêmico sobre o projeto da paz liberal no Haiti contemporâneo existem alguns livros, artigos e teses críticas - moderadas, híbridas ou hipercríticas - voltadas exclusivamente à interrogação da MINUSTAH, assim como trabalhos que mencionam esta missão específica como exemplo ilustrativo deste projeto liberal de governança global. Neste segundo caso, por exemplo, Oliver Richmond (2005, p. 86) aborda de passagem os debates técnicos sobre intervenções humanitárias, nos quais a MINUSTAH é classificada como operação de "terceira geração", devido ao seu caráter "multidimensional" de estratégia de construção da paz, ao mesmo tempo em que aponta a existência de fortes resistências locais à imposição deste modelo no país caribenho.

In Haiti, an attempt to install the liberal peace has faltered, despite its emphasis on democratisation, human rights, consensus-building, and civil society. (...) Perhaps unsurprisingly both the US and the UN learnt that offering the means to create the liberal peace to disputants did not automatically mean it would be accepted, and further, that forcing it upon them could lead to a violent response. The UN peace

\footnotetext{
${ }^{23}$ Não cabe no escopo desta tese fazer um mapeamento detalhado da literatura sobre hibridismo na teoria social contemporânea. Importa destacar que nos estudos pós-coloniais e decoloniais, esta noção foi inicialmente empregada para dar conta da forma de agência possível para sujeitos subalternizados pelo processo de colonização. As noções de diferença colonial e pensamento liminar de Mignolo (2003) captam esta concepção que ressalta a colonialidade do saber-poder, assim como o faz a proposta de culturas híbridas de Canclini (2005). Até mesmo a proposta de Bhabha faz parte desta atitude, que parte de baixo das hierarquias criadas pelo colonialismo, com o intuito de negar a possibilidade de uma identidade que se pretenda autêntica para os subalternizados, no que se assemelha, neste ponto, à célebre tese Spivak (1988). Por outro lado, a apropriação destas reflexões pelos teóricos (ocidentais e brancos) da Paz Híbrida, ainda que afirmem fazer uso de instrumental teórico pós-colonial, carecem desta mesma postura política, já que partem de um olhar de cima e com o intuito de sustentar as práticas intervencionistas em sociedades consideradas nãoocidentais (assim como suas próprias carreiras acadêmicas, construídas em torno do aprimoramento de tais práticas). É este o hibridismo que é foco de atenção principal na presente tese.
} 
support operation in Haiti confirmed this problematic move into the terrain of nation-building. (RICHMOND, 2005, p. 60-61)

Na mesma linha, um capítulo inteiro é dedicado à apreciação crítica da MINUSTAH pelo Oxford Handbook of United Nations Peacekeepping Operations (2015). Assinado por Nicolás Lemay-Hérbert, o capítulo faz um balanço da primeira década da missão que não ignora uma série de problemas envolvidos com a operação, além de dar espaço para seus críticos tanto no Haiti como em outras latitudes, como no Brasil, que destacaram a "securitização" de assuntos sociais e o desrespeito aos direitos humanos (2015, p. 724). Seu texto tem o mérito de inserir a MINUSTAH, mesmo que nos contextos histórico, social e político do Haiti, algo muitas vezes "eclipsado" até nas narrativas críticas (SABARATNAM, 2013, p. 266).

Dividindo a duração da missão em três períodos, o autor se refere ao primeiro deles (2004-2006) como agenda da estabilização após o "golpe” que forçou Jean-Bertrand Aristide ao exílio (LEMAY-HÉRBERT, 2015, p. 724; 726). Ao recordar que a supervisão de eleições era um componente-chave do mandato da força, ele também reconhece que denúncias de "fraudes" continuaram a ser frequentes no país sob a intervenção da MINUSTAH. Sobre o segundo período (2006-2010), focado em reformar o setor de segurança do Estado haitiano, ele critica a falta de coordenação entre os países doadores de ajuda, tão patente que teria motivado o representante do Secretário-Geral da ONU, Edmont Mullet, a declarar que a Polícia Nacional Haitiana seria um "exemplo do fracasso da comunidade internacional em trabalhar em conjunto". O autor conclui que a MINUSTAH terminou "reforçando as dinâmicas que haviam criado as tensões sociais em primeiro lugar" (2015, p. 725-726).

No terceiro e último período descrito, iniciado com o terremoto de 2010, a ênfase da missão seguiu sendo o campo da segurança, via ações militares. Tal securitização de questões sociais, segundo o autor, levou à criminalização de camadas populares e também de grupos políticos opositores ao novo regime implementado após o golpe de 2004, ou seja, aos apoiadores do ex-presidente JeanBertrand Aristide e seu partido, o Fanmi Lavalas, classificados até mesmo como "bandidos" e "terroristas" (2015, p. 726). ${ }^{24}$ Ao lembrar que o Haiti é marcado por

\footnotetext{
${ }^{24}$ Cumpre notar que tamanha criminalização da dissidência operada pelos interventores também recaiu com força sobre setores ainda mais à esquerda do Fanmi Lavalas, que eventualmente foi se
} 
uma forte "luta social" entre uma grande maioria empobrecida e uma pequena elite muito próspera, cujos interesses a MINUSTAH parecia defender, Lemay-Hérbert lamenta que a missão tenha servido ao propósito de fazer pender "o balanço de poder em favor de certos grupos em competição pelo controle do Estado haitiano" (2015, p. 726-727). Esta atitude, além de violar o princípio de neutralidade, também acabou gerando uma aposta na "solução militar" para desempatar o xadrez político haitiano, decisão que produziu centenas vítimas inocentes, "metade das quais eram mulheres e crianças", mas que foram consideradas friamente como "danos colaterais" aceitáveis pelos mais altos representantes da Comunidade Internacional no país (2015, p. 726).

Além disto, dedica-se uma seção completa aos casos emblemáticos que fizeram a MINUSTAH enfrentar grandes "dilemas de legitimidade" no Haiti, especialmente após a disseminação da epidemia de cólera por soldados nepaleses em 2010. Aborda também os inúmeros escândalos de abuso sexuais (incluindo menores de idade entre as vítimas) por parte das tropas estrangeiras de estabilização. ${ }^{25}$ Reconhece-se, ademais, em seu capítulo, a existência de amplo descontentamento da população local com a atuação da missão, destacando-se os massivos protestos de rua pedindo a saída da ONU. Também menciona a admissão, pelos próprios integrantes da MINUSTAH, do "papel divisor" que sua intervenção estaria significando para o país caribenho (2015, p. 726; 729). Ele termina com um chamado à realização de avaliações mais sérias e profundas, para além dos protocolares - e autoindulgentes - discursos sobre "lições aprendidas", a fim de assumir verdadeiramente a responsabilidade pelo impacto das intervenções internacionais nos países-alvo, como o Haiti.

Haiti's lack of proper sewage and sanitation systems exacerbated by the 2010 earthquake have been labeled a "perfect storm" for the outbreak of the massive epidemic of cholera. This has been used by the UN to absolve itself from responsibility for the outbreak of cholera while facing a pending multimilliondollar lawsuit. In the meantime, one could also use the cholera outbreak as a

acomodando (após ser desmembrado, expurgado e perseguido) ao novo regime político imposto pela MINUSTAH. No entanto, para as forças sociais que se mantiveram decididamente na oposição às tropas, o desrespeito à liberdade de expressão e atuação política prosseguiram agudos, como mostra a repressão sofrida por movimentos sociais como o Mouvement de Liberté d'Égalité des Haitiens pour la Fraternité (MOLEGAF), organizações feministas como a Solidarite Fanm Ayisyèn (SOFA), sindicatos de orientação trotskysta como o Bataille Ouvrière, além de movimentos estudantis e dos diversos partidos políticos haitianos que se opunham, à esquerda, ao então presidente Jean-Bertrand Aristide, quando de sua derrubada em 2004.

${ }^{25}$ Ver, a respeito, o bem documentado livro de Igor Patrick (2017). 
"perfect storm" analogy to understand the nature of local resistance to MINUSTAH, unveiling the limits of its securitization policy and of the international role in "strengthening" what has always been a highly politicized Haitian security sector. Similarly, debates surrounding the cholera outbreak shed new light on the "unintended consequences" of peacekeeping. Beyond the evaluation of outside interventions through "lessons learned" papers, the detrimental aspects of international presences, including the impact on local economies and structures of governance, also require attention. Haiti's cholera crisis put this agenda at the forefront of debates. In this context, a proper recognition of the social and political aspects of peace consolidation in Haiti must prevail over technocratic approaches. MINUSTAH has undoubtedly contributed to the "stabilization" of Haiti, even if at times in a politically partisan way. (...) What the UN may have failed to recognize in its successive Haitian missions, and perhaps most tellingly with MINUSTAH, is that international influences have historically been integral to Haiti's political processes. (2015, p. 729)

No âmbito acadêmico brasileiro, Ramón Blanco e Lucas Guerra (2017) dedicaram um artigo recente ao caso haitiano, no qual desenvolvem uma crítica consistente, porém moderada, à paz liberal no âmbito da MINUSTAH, ao estilo de Paris (2002), já que propõem aprimorar, mas não interromper, o intervencionismo. Em A MINUSTAH como missão civilizatória: uma análise crítica da política internacional para estabilização do Haiti (2017), os autores trazem à tona documentos do Fundo Monetário Internacional (FMI) e da própria ONU que apresentam recomendações centradas na liberalização econômica e institucional do país como único caminho para recuperar a economia local e o sistema político haitiano da crise crônica que os caracterizaria; ecoando, assim, as análises críticas de Pugh (2005) e Taylor (2010).

Para Blanco e Guerra (2017), tais recomendações normativas e sua internalização reproduzem as atitudes típicas das missões civilizatórias do colonialismo europeu, além de não necessariamente alcançarem seus próprios objetivos em termos de desenvolvimento econômico, estabilidade política e legitimidade das instituições governantes do país-alvo. Do ponto de vista econômico, a ênfase na desregulação laboral somada à promoção do setor privado visando o mercado externo vincularia "diretamente os setores produtivos nacionais às demandas do mercado internacional, introduzindo altos níveis de volatilidade $\mathrm{e}$ vulnerabilidade externa" (2017, p. 269). Sobre o âmbito político, eles mencionam o descontentamento de atores da sociedade civil haitiana com a "ausência de mecanismos de participação popular nos processos deliberativos das principais agências envolvidas com a Missão, caracterizadas por estruturas hierárquicas não democráticas" (2017, p. 270). Com isto em mente, concluem: 
Tendo isto em vista, constata-se que o estudo de caso da MINUSTAH permite exemplificar algumas das limitações da aplicação dos ditames da Paz Liberal em cenários pós-conflito. Frente a este paradigma, se faz necessária a busca por novas abordagens à construção da paz internacional, coerentes com as reivindicações e cosmovisões das populações locais e com protagonismo ativo destas ao longo do processo. Especificamente no caso da MINUSTAH, a abertura de espaços de diálogo e construção conjunta de soluções desde a sociedade civil haitiana para os problemas do país, rompendo com a lógica top-down até o momento vigente, apresenta-se como elemento essencial para a superação do paradigma civilizatório que tem marcado a atuação da Missão. (2017, p. 272)

Tendo em vista que os autores sugerem um maior engajamento com a população haitiana como forma de superar os problemas identificados na atuação da MINUSTAH, eles podem ser enquadrados no paradigma da virada local em voga nos estudos sobre intervencionismo multilateral, visto na seção anterior. Outra crítica, ainda mais conscientemente inserida no modelo da Paz Híbrida de superação da paz liberal está presente no artigo conjunto de Marta Moreno, Carlos Braga e Maíra Gomes (2012), que afirma trazer uma perspectiva pós-colonial sobre esta missão da ONU.

Estes autores reivindicam-se críticos do modelo dominante de operações, que visa transplantar o "consenso liberal" (estado centralizado, democracia e livremercado) para locais como o Haiti, afirmando discordar da visão que supõe que as operações de paz estejam livres de elementos neocoloniais (MORENO et al., 2012, p. 377). Sua tese central é que tal transplante de um modelo preconcebido é impossível, pois sempre há "negociações" e "adaptações" do mandato originalmente concedido quando se trata de implementá-lo em um caso concreto. Esta necessidade teria sido especialmente bem-sucedida em uma operação como a MINUSTAH, por ser composta majoritariamente de tropas advindas do Sul global (2012, p. 379).

Este "componente humano pós-colonial" teria o potencial gerar ambiguidades que embaralham as construções identitárias (Self/Other) que tradicionalmente marcam "encontros coloniais" como estes (2012, p. 379). Surpreendentemente, no entanto, esta abordagem pós-colonial leva os autores a uma avaliação excessivamente positiva desta missão da ONU no Haiti, que teria logrado romper com o padrão "logocêntrico" anteriormente criticado (2012, p. 379380). Imuniza-se, desta forma, esta missão contra o alcance de críticas acerca do "paradigma civilizatório" de outras operações de paz, mas que mesmo autores 
moderados como Blanco e Guerra (2017, p. 272) identificam como marcante do ethos da MINUSTAH. Segundo Moreno et al. (2012), pelo contrário, esta missão desestabilizaria o imaginário civilizatório da paz liberal.

\begin{abstract}
Instead of conceiving Haitian society as an empty space to be filled by a (UN) model, Latin American contingents of MINUSTAH have shown an alternative engagement with difference. By recognizing their internal (post-colonial) 'Others', bringing into the field their shared memories of suffering, Latin American components are able to establish a more empathetic relation with the host society and, simultaneously, to speak from an ambiguous site, potentially destabilizing the civilizational imaginary reproduced by the liberal peace model. MINUSTAH brought along a heavy Latin American participation (more than 60 per cent of the troops in 2010), including its leadership. (MORENO et al., 2012, p. 383)
\end{abstract}

Assim, mantém-se uma crítica à "literatura dominante sobre peacekeeping", ao passo em que se apresenta a MINUSTAH como um exemplo de alternativa para superar este modelo ocidental, uma vez que a atuação "inovadora" e "criativa" das tropas e comandantes brasileiros permite "ressignificar a receita da paz liberal" a partir da "desestabilização" e "deslocamento" das fronteiras identitárias coloniais, agora tornadas "ambíguas" e híbridas tanto por este tipo de análise, como pela prática de empregar contingentes de países que também já foram colônias neste tipo de operação (MORENO et al., 2012, p. 387-388). A paz liberal pode ser questionada ao mesmo tempo em que os supostos "sucessos" da MINUSTAH em "reinventar" ou transcender as limitações do modelo dominante também são ativamente celebrados (2012, p. 384-387). Tal análise, como na literatura sobre Paz Híbrida, vista anteriormente, tenta acrescentar uma linguagem pós-colonial ao rol de discursos brasileiros favoráveis à ocupação do Haiti, argumentado que trata-se de algo qualitativamente distinto do modelo tradicional de paz liberal, ainda que carregue algumas similaridades inescapáveis. ${ }^{26}$ Dada sua relevância para o argumento central desta tese, esta abordagem será recuperada mais intensamente nos capítulos 5 e 6 da presente investigação.

\footnotetext{
${ }^{26}$ Este argumento sobre o caráter qualitativamente distinto da MINUSTAH frente a outras missões de paz também será mobilizado, como será visto adiante (mais detalhadamente no capítulo 5), por outras análises de Relações Internacionais igualmente simpáticas à atuação brasileira nesta operação, mas que não necessariamente fazem uso de instrumental teórico pós-colonial ou da $\mathrm{Paz}$ Híbrida. Ainda que por vias distintas, todas terminam reiterando os discursos autoelogiosos das autoridades estatais brasileiras para justificar sua posição de destaque na missão no Haiti entre 2004 e 2017.
} 
Por outro lado, a tese de Maíra Siman Gomes (2014) oferece uma análise mais consistente, mediante uma releitura pós-estruturalista do engajamento brasileiro na MINUSTAH. Seu trabalho já introduz parte do argumento avançado na presente investigação, que lhe é assim tributária (principalmente no que se refere às alteridades entre Brasil e Haiti, perceptíveis no modo como o pensamento social brasileiro analisou o Haitianismo, analisado no capítulo 3). Esta autora destrincha as práticas discursivas que sustentaram a decisão do governo brasileiro em participar da MINUSTAH destacando, dentre outras, a operatividade de uma lógica da similaridade sobre a qual se apoiam noções legitimadoras, como o princípio da não indiferença:

Seguindo essa lógica, entende-se que, dentre outros aspectos, o Brasil pode - e deve - liderar a missão da ONU no Haiti não apenas porque ele compartilha um quadro identitário com o Haiti (passado colonial, escravidão, sincretismo religioso, etc), mas especialmente porque o Brasil tem sido capaz de enfrentar vários dos problemas historicamente vividos pela sociedade haitiana. Nesse sentido, seria como dizer que o Brasil "conhece" o Haiti e pode ajudá-lo, porque, de alguma forma, o Haiti lhe é familiar.

Argumenta-se, portanto, que o "princípio da não indiferença" reproduz discursivamente uma forma específica de conceber o "outro" e o relacionamento entre "eu" e "outro". Tal discurso articula similaridades entre "eu" e "outro" e, em outros termos, constrói uma representação de que não se pode ser indiferente diante daquele que não nos é completamente diferente; não se pode ser indiferente diante do "outro similar". Nesse caso, defende-se que, embora o Haiti seja aquele "outro" que, de algum modo, é ainda pensado em uma posição inferior ao self brasileiro (uma vez que, não se pode negar, o Brasil é considerado aquele que tem capacidade para intervir e assistir na construção do Estado haitiano), busca-se pelo princípio da "não indiferença" legitimar a intervenção com base na ideia de que "eu" e "outro" compartilham valores e experiências. (Gomes, 2014, p. 211 - itálico no original)

Ao complementar esta lógica da similaridade com as lógicas da assimilação complexa e a apaziguadora do conflito, Gomes (2014, p. 173) capta três ferramentas discursivas que trabalham para estabilizar recorrentemente uma versão dominante daquilo que chama de Self estatal brasileiro. Apesar de se inserir no campo de estudos de Política Externa, ela identifica como "os discursos e práticas da pacificação atuam (re)produzindo um determinado 'Brasil'” e, mais importante ainda, como "funcionam como ideal regulatório, por meio do qual a contingência pode ser "domesticada", tanto no sentido de ser "trazida para dentro" do estado, quanto controlada" (GOMES, 2014, p. 174). Trata-se, portanto, de um trabalho crítico não apenas à MINUSTAH, mas principalmente aos usos políticos que as agendas de pacificação dos Outros, dentro e fora do país, tentam avançar. 
Uma postura ainda mais contundente - definitivamente hipercrítica - pode ser encontrada na tese de doutorado de Franck Seguy (2014), sociólogo haitiano que fez sua pesquisa na Universidade Estadual de Campinas (UNICAMP), cujo título é A catástrofe de janeiro de 2010, a "internacional Comunitária" e a recolonização do Haiti (2014). Lançando mão de uma abordagem descolonial, o autor entende as intervenções exteriores no Haiti como partes do "projeto da modernidade", considerado culpado pelas mazelas sofridas pelo povo haitiano, segundo sua perspectiva. Para ele, o constante pedido por mais modernização no Haiti seria parte do problema, não da solução (SEGUY, 2014, p. 179).

Enquanto a única solução posta para o Haiti é adentrar-se na modernidade política e econômica ou na modernização de suas estruturas mais profundas, pretendemos mostrar que o projeto civilizatório da modernidade é justamente o responsável pelo processo de degradação acelerada da vida humana que toma conta do país tal qual é desvelado pelo terremoto de 12 de janeiro de 2010. Portanto, o Haiti põe a nu a face colonial camuflada da modernidade, ao mesmo tempo em que mostra o verdadeiro caráter e os limites do seu projeto civilizatório, os quais são bem visíveis no processo de continuidade de desumanização da vida mais acelerado do que nunca no Haiti de hoje. (2014, p. 179)

Valendo-se extensivamente das análises de Walter Mignolo (2007), para quem "não se pode ser moderno sem ser colonial", ele reconhece o Haiti nesta "lógica da colonialidade" (Mignolo, 2007, p. 32; 36), afirmando que "foi junto com a colonização e a escravidão que a modernidade chegou ao Haiti” (SEGUY, 2014, p. 224). E prossegue:

Para quem quer falar em modernidade neste singular pequeno país é preciso lembrar que a modernidade, a colonização e a escravidão foram os três pilares sobre os quais se edificou o capitalismo. Isto é, foi pelo terceiro caminho, o da via traumática da conquista colonial que o Ayiti adentrou-se na modernidade. (2014, p. 224)

A tese de Seguy (2014) sugere, já no título, que há uma tentativa de recolonização do Haiti em curso, acelerada desde o terremoto de 2010, que teria propiciado um aprofundamento da intervenção realizada por aquilo que chama de "Internacional Comunitária". Seu argumento, neste sentido, também se coaduna com as análises de Pugh (2005) e Taylor (2010), ao reconhecer a oportunidade que 
situações extremas trazem para os agentes promotores do "capitalismo de desastre", conforme batizado por Klein (2007). ${ }^{27}$

O enfoque de Seguy (2014), no entanto, privilegia variantes luckatianas do marxismo (LUKÁCS, 1979; MÉSZAROS, 2004) em conjunto com o emprego de abordagens decoloniais (MIGNOLO, 2007; QUIJANO, 2005), o que lhe permite tratar a sociabilidade capitalista a partir dos seus efeitos sobre as vidas cotidianas no Haiti, ou seja, percebendo como a "ordem sociometabólica do capital" também faz parte dos "fundamentos ontológicos da modernidade" (SEGUY, 2014, p. 190; 221). Assim, ao criticar frontalmente os projetos modernizantes de Hegel, Weber e Habermas, intelectuais muito difundidos em seu país, Seguy (2014) apresenta proposições decoloniais contraintuitivas, até mesmo "desorientadoras" (SABARATNAM, 2013, p. 274), pois invertem uma vez mais os discursos frequentes sobre o Haiti, que geralmente apregoam a existência de um caos hobbesiano, o qual somente poderia ser tratado com a instauração de um Estado moderno e eficiente, tendo em vista a incompletude ou falência do Estado haitiano.

Pretendemos mostrar que o Estado moderno é um sucesso no Haiti, que ele era imprescindível para o processo de recolonização do país depois da proclamação da independência e que ele é responsável pela tirania, injustiça, ignorância e miséria que tanto no século XIX quanto no século XX ou XXI ritma o quotidiano do seu povo dentro do hemisfério ocidental. (SEGUY, 2014, p. 190-191) $)^{28}$

O que seria preciso, segundo o autor, seria realizar uma "recusa da epistemologia da modernidade" (2014, p. 236), uma vez que "a retórica da modernidade trabalha mediante a imposição da salvação" (MIGNOLO, 2007, p.

\footnotetext{
${ }^{27}$ Cf. Klein, Naomi. The Shock Doctrine: the rise of disaster capitalism. London: Penguin Books, 2007. Em Humanitarismo e a questão racial no Haiti (2015), Seguy lança seu olhar hipercrítico para as agências de cooperação para o desenvolvimento e ONGs advindas dos países doadores.

${ }^{28}$ Para a crítica sistemática dos discursos calcados nas características supostamente caóticas do Haiti, ver o livro da antropóloga haitiano-americana Gina Ulysse (2015). Para uma crítica decolonial das narrativas acerca da suposta excepcionalidade do Haiti, e do Caribe em geral, no que tange às formas de soberania política, ver: Bonilla (2013). No Brasil, mesmo um crítico severo da MINUSTAH, como Seitenfus (2016), reproduz este expediente, provocando o rechaço de Raoul Peck [2014], impresso como prefácio, de modo geral elogioso, à mesma edição: "Algunos análisis y conclusiones de Ricardo Seitenfus pueden suscitar el debate. Su análisis, a veces puede mostrarse culpable de los extravíos que él denuncia, cuando pregunta: "¿Qué hay de extraordinario en la tierra de Toussaint Louverture que pueda explicar su inadaptabilidad constante a la modernidad? ¿No está utilizando él mismo la concepción eurocéntrica de la modernidad? ¿Esa que niega la existencia y el rol "de las periferias" en la historia universal? ¡Nosotros somos los que hemos inventado la modernidad!” (SEITENFUS, 2016, p. 25).
} 
463), propiciando assim as condições discursivas de possibilidade para as práticas intervencionistas que se propõem a salvar ou consertar o Haiti. ${ }^{29}$ Seguy (2014) se insurge contra "a dificuldade desses intelectuais moderno-coloniais-racistas [de] admitirem que possam existir na face da terra outras perspectivas que não sejam pensadas e concebidas dentro da ontologia colonial moderna racista" (2014, p. 242). Para ele, uma forma radical de recusa a este eurocentrismo é encontrável no discurso proferido pelo ex-escravizado e posteriormente líder insurrecional Dutty Bouckman, durante Congresso de Bois-Caïman, em 14 de agosto de $1791 .^{30}$ Este momento é considerado o início da Revolução Haitiana, que poria fim à escravidão e conseguiria a independência frente ao domínio colonial, "um dos mais importantes congressos políticos já realizados contra a visão de mundo promovida pela ideologia da modernidade/colonialidade" (2014, p. 237). ${ }^{31}$

Deve-se mencionar também o impactante trabalho da antropóloga feminista haitiano-americana Gina Athena Ulysse (2015). Ela faz profundas críticas, tanto teóricas como políticas, às práticas discursivas e intervencionistas ocidentais, especialmente dos Estados Unidos da América, França e Canadá sobre seu paísnatal. Em Why Haiti Needs New Narratives: a Post-Quake Chronicle, Ulysse (2105) aborda não apenas a MINUSTAH em sua obra - publicada numa edição conjunta em inglês, francês e kreyòl-mas todos os agentes envolvidos naquilo que ela chama, tomando de empréstimo uma expressão de Gregory Fox (2008), de ocupação humanitária do Haiti. Filiando-se ao grupo de cientistas sociais "periferizados" e engajados no projeto de descolonizar os estudos antropológicos, ela se dedica a produzir "conhecimento opositor" (oppositional knowledge) àquilo

\footnotetext{
${ }^{29}$ Fixing Haiti é justamente o título de uma coletânea de artigos organizada por Andrew Thompson e Jorge Heine (2011) e publicada pela United Nations University Press, o autodeclarado "braço editorial das Nações Unidas". Ele pode ser lido em (acesso junho 2018): https://collections.unu.edu/eserv/UNU:2516/ebrary9789280811971.pdf.

${ }^{30} \mathrm{O}$ famoso pastor evangélico norte-americano Pat Robertson argumentou ao vivo, em seu programa de televisão, que este congresso teria marcado o "pacto do Haiti com o diabo", o que explicaria as catástrofes naturais e mazelas sociais sofridas pelo país. O terremoto de 2010 é descrito como uma "benção disfarçada", que poderia acelerar o a conversão dos haitianos e haitianas para o cristianismo. O vídeo foi republicado pela rede $C B S$ News e pode ser visto em (acesso junho 2018): https://www.cbsnews.com/news/pat-robertson-haiti-cursed-after-pact-to-the-devil/.

31 "O Bom Deus que criou o sol que nos ilumina do alto/ Que subleva o mar e faz retumbar o trovão/ Escutai bem, vós: Este Bom Deus escondido nas nuvens está olhando para nós

Ele vê o que estão fazendo os brancos /O deus dos brancos só quer crime/ O nosso quer apenas bemestar/ Mas este Deus tão bondoso ordena a vingança!/ Ele guiará nossos braços, nos assistirá/ Jogai fora a imagem do deus dos brancos que está com sede de nossas lágrimas/ E escutai a voz da Liberdade que está falando ao nosso coração!” (BOUCKMAN, 1791 citado por SEGUY, 2014, p. 238).
} 
que classifica como "complexo-industrial-dos-salvadores-brancos" (2015, p. xxvi; xxxiii), que invisibiliza os sujeitos salvados:

Where, if, and how "natives" fit in this visual (economic) order, especially in the areas of humanitarian work and post-disaster reconstruction, given their domination by a white-savior-industrial-complex, remained unanswered "burning questions", as Michel-Rolph Trouillot would have dubbed them a decade earlier.

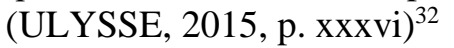

Outro trabalho de fôlego e hipercrítico à MINUSTAH é aquele realizado por Ricardo Seitenfus (2016) que, no universo acadêmico brasileiro das RI, aparece como um dos mais sistemáticos denunciantes da última intervenção da Comunidade Internacional $^{33}$ no Haiti. Professor de Relações Internacionais e ocasionalmente diplomata, Seitenfus foi enviado especial da Organização dos Estados Americanos (OEA) ao Haiti entre 2009 e 2011. Anteriormente, ele já havia participado brevemente da primeira das oito missões multilaterais enviadas ao país entre 1993 e $2017 .^{34}$

No início da MINUSTAH, Seitenfus (2006) apregoava visões muito positivas a respeito da missão, a qual classificava como exemplo de "uma nova matriz ideológica e operacional" capaz de "romper o ciclo marcado pela indiferença ou pela ineficácia das soluções sugeridas frente aos conflitos que afligem os países em desenvolvimento" (2006, p. 5). Para ele, naquele momento, a atuação da ONU no Haiti, com destaque para a postura brasileira, exemplificaria o que chamou de “ingerência solidária" (2006, p. 5), que se diferenciaria dos modelos de paz liberal difundidos até então pelos países do Norte global.

\footnotetext{
${ }^{32}$ Para uma crítica similar, advinda de um lugar de fala diametralmente oposto, mas que também questiona aquilo que chama de charitable industrial-complex e Philantropic Colonialism, ver Peter Buffet (2013), filho do multimilionário norte-americano Warren Buffet e responsável pela NoVo Foundation. Disponível em (acesso em julho de 2018): https://www.nytimes.com/2013/07/27/opinion/the-charitable-industrial-complex.html.

${ }^{33}$ Tanto Seitenfus (2016) quanto, antes dele, Heathershaw (2008) usam letras maiúsculas para a Comunidade Internacional, para denotar uma forma de agência e intencionalidade ao conjunto dos interventores internacionais: "Hereafter the idea of 'international community' will be capitalised to International Community to convey its centrality as an identity signifier in peacebuilding discourse" (HEATHERSHAW, 2008, p. 2). Seguy (2014) avança neste caminho e, indo além, decide cunhar um novo conceito, "Internacional Comunitária", a partir do trocadilho com as antigas Internacionais, socialistas e comunistas. Possivelmente inspirou-se no título do livro de René Armand Dreifuss, "A Internacional Capitalista" (1987), que traz o mesmo jogo de palavras.

${ }^{34}$ Após esta primeira estadia, em 1993, Seitenfus publicou um livro dedicado ao estudo do país, intitulado Haiti: a soberania dos ditadores (1994). Nesta época, ele havia atuado na Missão Internacional Civil no Haiti (MICIVIH), conjunta entre ONU e OEA, estritamente civil, "para intentar hacer que se respetasen los derechos humanos durante la dictadura de Raoul Cedras" (SEITENFUS, 2016, p. 230). Sobre esta missão, ver também Câmara (1998).
} 
A situação descrita sucintamente indica a importância da construção de uma teoria da intervenção solidária pelos países do Sul, caso contrário eles continuarão a mercê do modelo aplicado pelos países desenvolvidos. Por essa razão, a crise haitiana possui um significado que vai bem além de suas fronteiras, podendo servir de modelo para futuras mediações. (...) Enfim, existe uma realidade de intervenção que se manifesta por diversos tipos, o que permite desenhar uma tipologia da intervenção, em que se inclui a ingerência solidária. Esta não é o contrário do princípio da não intervenção, mas ela é uma exceção a ele e, dialeticamente, o afirma ao dizer os seus limites quando indaga sobre qual soberania deve ser defendida: a do povo ou a do ditador? $(2006$, p. 7$)$

No entanto, tamanho otimismo analítico não sobreviveria à vivencia in loco que o autor experimentaria poucos anos depois. Em seu livro mais recente, publicado uma década após o artigo mencionado, Seitenfus (2016) opera uma guinada dramática em suas posições iniciais sobre o tema, passando de defensor a um crítico mordaz da MINUSTAH, vista agora como ponta de lança daquilo que classifica como "tridente imperial". ${ }^{35}$ Ecoando as análises de Seguy (2014) acerca de uma suposta recolonização do Haiti (ainda que sem citar diretamente seu trabalho), Seitenfus (2016) passa a jogar ênfase no papel neocolonial e opressor que as grandes potências exercem sobre o país desde sua independência. A premissa mais importante desta nova postura, atualmente hipercrítica, em relação à missão, é que este modo de lidar com o Haiti tem raízes na própria Revolução Haitiana (1791-1804) e no risco que o mal exemplo haitiano passou a desempenhar no imaginário ocidental desde então.

El Occidente colonialista y racista, inspirado por la posición francesa, define una estrategia, cuya aplicación se extenderá durante dos siglos alcanzando los días actuales. La misma comprende cinco dimensiones:

1. establecer un cordón sanitario que excluya Haití de las relaciones internacionales;

2. debilitar el Estado haitiano, tornando el país ingobernable;

3. crear condiciones culturales y psicológicas en Occidente, haciendo que todo lo

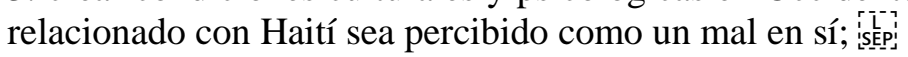

4. construir una narrativa de la sociedad haitiana que la muestre como una amenaza a los fundamentos de las relaciones internacionales; ;sep:

5. alimentar sentimientos de pánico, temor y cobardía frente a Haití. $(2016 \text {, p. 52) })^{36}$

\footnotetext{
${ }^{35}$ Ver também: SEITENFUS, R. "Hillary Clinton and Haiti". Counter Punch, 11/04/16. Disponível em (acesso Junho/2018): https://www.counterpunch.org/2016/04/11/hillary-clinton-and-haiti/. ${ }^{36} \mathrm{O}$ autor chega a mencionar o "Haitianismo" como expressão desse imaginário no Brasil, sendo algo que "[p]ara los esclavistas se trababa de un mal que debía ser extirpado de sociedad brasileña" (SEITENFUS, 2016, p. 55). De acordo com a historiografia por ele seguida, o Haitianismo "se tornou a expressão que definiria a influência daquele movimento sobre a ação política dos negros e mulatos, escravos e livres nos quatro cantos do continente Americano" (REIS, 2000, p. 248). Nos capítulos 3 e 4 desta tese coteja-se a produção historiográfica brasileira sobre o Haitianismo com fontes primárias de época imperial de modo a situar este entendimento tradicional num quadro mais amplo de interpretações.
} 
Deste modo, a nova postura de Seitenfus (2016) agrega à estas premissas anticoloniais uma série de elementos empíricos, elencados por um autor que os observou, por vezes, na condição de testemunha ocular dos episódios. Destacamse, dentre eles, as movimentações continentais que produziram a derrubada do presidente democraticamente eleito, Jean-Bertrand Aristide, em 2004; as sucessivas fraudes nos processos eleitorais sob os auspícios da MINUSTAH que sucederam sua deposição; a introdução da epidemia de cólera por soldados da ONU, que contaminou 800 mil haitianos e tirou a vida de mais de 8 mil; o uso desmesurado de violência contra civis; a seletividade na ajuda humanitária pós-terremoto; e, sobretudo, a ilegalidade em termos de direito internacional e também frente à constituição haitiana de tal intervenção que, na visão do autor, significa o sequestro da soberania daquele país $\left(2016\right.$, p. 183-231). ${ }^{37}$

\section{Críticas à MINUSTAH para além da academia}

Apesar da escassa quantidade de literatura acadêmica que se dedique exclusivamente à análise crítica da MINUSTAH, é possível encontrar com facilidade um vasto cabedal de abordagens críticas em outros campos de atuação, cada qual com seu formato, objetivo e epistemologias particulares. Existem, por exemplo, inúmeras reportagens na imprensa internacional sobre os casos de abuso sexuais cometidos no Haiti durante esta missão da ONU, por vezes praticados pelos próprios soldados e oficiais, sem contar os funcionários de agências civis. ${ }^{38} \mathrm{~A}$ grande imprensa brasileira deu consideravelmente menos atenção a tais episódios, fazendo dos meios alternativos ou ligados a meios de comunicação estrangeiros a única opção para quebrar o bloqueio midiático nacional sobre o que acontecia no Haiti ocupado por tropas lideradas pelo Brasil.

Uma postura destoante deste padrão encontra-se no livro de Igor Patrick (2017), fruto de uma longa reportagem especialmente dedicada ao tema das violações sexuais cometidas pelos próprios integrantes da MINUSTAH, incluindo soldados brasileiros. São entrevistas originais com as "haitianas estupradas pelos

\footnotetext{
37 Para além da MINUSTAH, mas ainda no âmbito da ingerência estrangeira no Haiti contemporâneo, Seitenfus (2016) dedica um capítulo inteiro à interrogação crítica das ONGs que operam no Haiti, que contabilizam mais de 10 mil instituições, um aumento de $4.000 \%$ após o terremoto de 2010 (2016, p. 317-340). Este número também é denunciado por Ulysse (2015, p. 57).

${ }^{38}$ Ver, sobre o tema, a investigação especial da agência Associated Press publicada em abril de 2017 sobre os escândalos sexuais no Haiti ocupado pela MINUSTAH, destacando os casos de pedofilia envolvendo peacekeepers, em junho 2018): https://apnews.com/e6ebc331460345c5abd4f57d77f535c1.
} 
soldados da ONU", conforme o subtítulo já informa. Os relatos, chocantes, incluem não apenas estupro de menores de idade, mas também uma prática (igualmente considerada como abuso sexual pelas regras da $\mathrm{ONU}$ ) de se trocar sexo por comida (2017, p. 100). Ele relata a resposta que recebeu de um embaixador brasileiro em Porto-Príncipe quando tentou interceder a favor de uma haitiana abusada por um militar brasileiro, que ele tinha entrevistado. O diplomata "se recusou a recebê-la ou mesmo a conversar com ela por telefone [porque] estaria indiretamente validando sua denúncia (...). "Diga a ela que procure um advogado ou uma ONG", teria dito o embaixador (PATRICK, 2017, p. 116). O jornalista, no entanto, ao final de seu livro apresenta uma postura reformista, no sentido de melhorar a postura dos soldados, em vez de advogar o fim deste tipo de operação.

Caso similar acontece também quando os escândalos envolvem ONGs, como a britânica Oxfam, que recentemente viu-se envolvida em um episódio de violações sexuais e utilização de redes de prostituição por seu diretor-executivo no Haiti, logo após o terremoto de 2010. ${ }^{39}$ Assim como nos casos envolvendo militares, a grande imprensa brasileira preferiu seguir a linha discursiva emanada dos comandantes da MINUSTAH, que admitiam alguns incidentes (111 soldados do Siri Lanka foram repatriados em 2007, após comprovação de envolvimento com abusos sistemáticos, inclusive contra menores de idade) mas eximiam-se da responsabilidade ao afirmar que nenhum brasileiro foi comprovadamente considerado culpado em nenhum caso. No entanto, as denúncias também recaíram sobre pessoal civil e militar brasileiro, sendo que a grande parte não foi adequadamente investigada ou sequer considerada (PATRICK, 2017, p. 116122). ${ }^{40}$

Algumas exceções lograram romper o bloqueio midiático, como a reportagem de Cristiano Dias (2010) no jornal O Estado de S. Paulo, que menciona

\footnotetext{
${ }^{39}$ Ver, sobre o caso, a reportagem da BBC (acesso junho 2018): https://www.bbc.com/news/uk43163620.

${ }^{40}$ Em comunicação pessoal (não requisitada) após debate sobre a MINUSTAH na Semana de Defesa e Gestão Estratégica Internacional da UFRJ, em 2013, este autor (na época professor substituto naquele curso) foi abordado por um oficial da Marinha do Brasil que afirmava serem os relatos de estupro sempre uma mentira inventada por forças políticas 'locais' opostas às missões da ONU, fato que ele já aprendera em sua passagem por missões anteriores 'na África'. Sua postura era desafiadora e seu tom foi intimidador, como se estivesse pessoalmente ofendido pelas críticas feitas à MINUSTAH, que haviam sido recebidas com interesse pelo público presente ao auditório, minutos antes. Com ares de ameaça, avisou que iria fazer uma visita ao Instituto Políticas Alternativas para o Cone Sul, que participava da campanha pela retirada da MINUSTAH, instituição à qual este autor estava vinculado à época.
} 
repetidas vezes o "Haitianismo" como razão do isolamento "que selou o destino do país" caribenho. ${ }^{41}$ Por sua vez, o Le Monde Diplomatique abriu espaço para um artigo de Borba de Sá, Said e Wansetto (2017) que fazem um escrutínio contundente sobre diversos aspectos negativos da MINUSTAH, na tentativa de alertar sobre "o perigo da indústria humanitária brasileira". ${ }^{42} \mathrm{Na}$ fronteira entre a grande imprensa e os meios alternativos, a revista Carta Capital publicou um número especialmente dedicado ao Haiti ocupado pela MINUSTAH, no qual a maioria das reportagens apresenta um tom crítico à missão, ainda que contrabalançados por iniciativas consideradas positivas, realizadas por entidades brasileiras em solo haitiano, como os trabalhos da ONG Viva Rio ou da Brigada Dessalines, do Movimento dos Trabalhadores Rurais Sem-Terra (MST). ${ }^{43}$

Existem filmes críticos, em formato de documentário, sobre a MINUSTAH e o Haiti sob ocupação internacional. O cineasta haitiano Raul Peck, ganhador do Oscar por Eu Não Sou Seu Negro (2016), também lançou Assistência Mortal (2013), documentário que questiona as agências de ajuda humanitária que operam no seu país. Outro documentário de qualidade, lançado um ano após o início da MINUSTAH é aquele realizado por Nicolas Rossier, Aristide and the endless revolution (2005). Esta obra possui imagens inéditas, capturando bem os discursos da elite haitiana e, principalmente, dos estrategistas e autoridades governamentais norte-americanas, que construíram discursivamente a necessidade de intervir no Haiti entre fevereiro e março de 2004 (inclui um pronunciamento público revelador do então presidente George W. Bush, que saudava o início de um "novo capítulo na história do Haiti" enquanto ordenava o envio imediato de fuzileiros navais para garantir ordem e estabilidade ao país). Um dos entrevistados é o ator norteamericano Danny Glover, sempre engajado em campanhas pelos direitos humanos

\footnotetext{
${ }^{41}$ DIAS, Cristiano. “O vizinho que ninguém quer ter”. O Estado de S. Paulo, 16/01/2010. Disponível em (acesso em maio 2018): https://www.estadao.com.br/noticias/geral,o-vizinho-que-ninguem-quer-ter,496960.

${ }^{42}$ Borba de Sá et al. "Militarização tipo exportação: o perigo da indústria humanitária brasileira". Le Monde Diplomatique - Brasil, 04/10/2017. Disponível em (acesso em junho 2018): http://diplomatique.org.br/militarizacao-tipo-exportacao-o-perigo-da-industria-humanitariabrasileira/.

${ }^{43}$ Ver edição especial em (acesso em junho 2018): https://www.cartacapital.com.br/especiais/haiti Em entrevista feita pelo autor com representantes do MST na sede da Brigada Dessalines, em Montrouis, localizada a uma hora e meia da capital, representantes do movimento afirmaram sua posição inequivocamente contrária à existência da MINUSTAH e enfatizaram, ainda que respeitosamente, a sua distância política frente ao trabalho de ONGs brasileiras no país. A principal aliança do MST no Haiti, informam, é com o movimento camponês haitiano, principalmente com o Tet Kole, entidade que, assim como o MST, é membro da Via Campesina.
} 
e contra as tropas de intervenção no Haiti, assim como a senadora do Partido Democrata, Maxine Waters ${ }^{44}$.

No Brasil, pelo menos duas campanhas de abrangência nacional, parte de campanhas continentais, foram organizadas por movimentos sociais, partidos políticos, ONGs, sindicatos, personalidades políticas e artísticas pedindo a saída das tropas da MINUSTAH do Haiti. Por exemplo, a Rede Jubileu Sul organizou, ainda em 2005, uma Missão Internacional de Investigação e Solidariedade ao povo haitiano, no intuito de registrar as ações das tropas e agências interventoras no país ocupado. ${ }^{45}$ Desta iniciativa, resultou um Relatório Final (2007) publicado pela editora Expressão Popular ${ }^{46}$ e um filme em formato documentário, ambos com o mesmo nome, Haiti: Soberania e Dignidade (2005). ${ }^{47}$ A mesma rede, junto com outras entidades, organizou posteriormente a Campanha Permanente pela Retirada das Tropas do Haiti, que realizou seminários, debates, panfletagens, materiais educativos e vídeos críticos à MINUSTAH, como Haiti: 100 anos de ocupação (2016). ${ }^{48}$ Anualmente, no mesmo dia em que o Conselho de Segurança da ONU votava a renovação do mandato da MINUSTAH, esta campanha protocolou cartas de repúdio à continuidade da intervenção no Ministério das Relações Exteriores brasileiro e no escritório do Centro de Comunicação da ONU no Brasil. ${ }^{49}$ Outra iniciativa foi a criação do Comitê Defender o Haiti é Defender a Nós Mesmos ${ }^{50}$ que, devido a sua proximidade com o Partido dos Trabalhadores (PT), conseguiu produzir fricções internas sobre este tema no governo federal presidido pelo mesmo partido. Atuando em conjunto com outras organizações, também realizou

\footnotetext{
${ }^{44}$ As declarações de Bush foram reproduzidas pelo jornal The New York Times, em matéria assinada por Lydia Polgreen e Tim Weiner (2004), disponível em (acesso em junho 2018):

https://www.nytimes.com/2004/02/29/international/americas/haitis-president-forced-out-marinessent-to-keep. html. Para assistir o documentário ver (acesso junho 2018):

https://www.youtube.com/watch?v=c25ycxwoWtc.

${ }^{45}$ Para uma descrição desta missão da sociedade civil organizada da América Latina e Caribe, em alternativa à missão oficial das Nações Unidas, ver (acesso junho 2018):

http://www.voltairenet.org/article124673.html.

${ }^{46}$ Para ler o relatório (acesso junho 2018):

https://issuu.com/rbrasil/docs/haiti_soberania_dignidade.

${ }^{47}$ Para ver o filme completo (acesso junho 2018):

https://www.youtube.com/watch?v=fwZ1f56sOqA\&t=23s.

${ }^{48}$ Ver por exemplo (acesso junho 2018):

https://www.ceert.org.br/noticias/direitos-humanos/6988/campanha-intensifica-pressao-pelaretirada-das-tropas-brasileiras-do-haiti. Para assistir ao documentário, ver (acesso junho 2018):

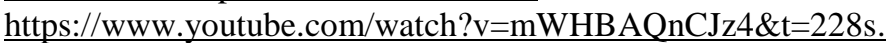

${ }^{49}$ Para um exemplo do teor deste tipo de carta, ver (acesso junho 2018):

http://www.pacs.org.br/2014/10/07/carta-de-rechaco-a-renovacao-do-mandato-da-minustah-nohaiti-america-latina-e-caribe-outubro-de-2014/.

${ }^{50}$ Ver (acesso junho 2018): http://retiradatropashaiti.blogspot.com/.
} 
atividades e manifestações, incluindo audiências públicas em parlamentos estaduais. ${ }^{51}$ Tais movimentos, por fim, pressionaram autoridades do Ministério da Defesa e das Relações Exteriores em audiências públicas no Congresso Nacional convocadas para discutir a situação dos imigrantes haitianos chegando ao Brasil e a retirada das tropas do Haiti. ${ }^{52} \mathrm{O}$ alcance de tais iniciativas críticas junto à opinião pública brasileira, no entanto, foi limitado.

Foi no próprio Haiti onde pôde-se ver a mais forte oposição à MINUSTAH. Encontra-se repúdio à esta intervenção em praticamente todos os segmentos da sociedade haitiana, fato reconhecido até mesmo por embaixadores brasileiros no país. ${ }^{53}$ Do movimento estudantil aos movimentos de mulheres e feministas, passando por uma ampla gama de outros movimentos sociais e entidades como ONGs, sindicatos, partidos políticos, além de intelectuais, a rejeição à intervenção internacional é uma tônica. Há coletivos dedicados especialmente a manifestar-se sobre este tema, como o Movimento de Liberdade e Igualdade dos Haitianos pela Fraternidade (MOLEGHAF), que até os últimos dias da MINUSTAH em 2017 protestou semanalmente, todas as quintas-feiras, às 10 horas da manhã, em frente à embaixada norte-americana em Porto Príncipe, exigindo a saída imediata das tropas estrangeiras. Mesmo as entidades que se opunham ao governo de Jean-Bertrand Aristide posicionaram-se contra a MINUSTAH. ${ }^{54} \mathrm{O}$ Senado haitiano repetidamente votou contra a permanência das forças da ONU em seu país, tendo suas decisões ignoradas pela Comunidade Internacional. Senadores haitianos chegaram a vir ao Senado Federal em Brasília pedir apoio aos seus colegas senadores no Brasil para interceder junto ao governo federal sobre o tema. ${ }^{55}$

\footnotetext{
${ }^{51} \operatorname{Ver}$ (acesso junho 2018): http://www.camara.sp. gov.br/blog/audiencia-publica-discute-aretirada-de-tropas-do-haiti/.

${ }^{52}$ Ver (acesso junho 2018): https://haitinominustah.info/2015/07/30/jubileu-sul-brasil-participarade-audiencia-sobre-haiti-marcada-para-proxima-segunda-feira-3/.

${ }^{53}$ Ver (acesso junho 2018) reportagem da BBC - Brasil de 29/02/12, cujo título é: "Haiti se tornou laboratório para Brasil, diz embaixador":

https://www.bbc.com/portuguese/noticias/2012/02/120228 haiti_entrevista_embaixador_jf.

Ver também o artigo de Lemay-Herbert (2015), supracitado, que cita um conselheiro da embaixada brasileira em Porto Príncipe reconhecendo a hostilidade local contra o que passou a ser visto como uma "força de ocupação" liderada pelo Brasil (2015, p. 728).

${ }^{54}$ Ver o informe preparado pela Plataforma de Orgazaciones Haitianas de Derechos Humanos (POHDH), intitulado La Minustah y la violación de los derechos humanos em Haiti (2012).

${ }^{55}$ Ver reportagem da página do Senado Federal (acesso Junho/2018):

https://www12.senado.leg.br/radio/1/noticia/senador-haitiano-pede-apoio-a-retirada-das-tropas-daonu-do-haiti.
} 
Por fim, pode-se encontrar também uma boa quantidade de ensaios livres produzidos por intelectuais ou think-tanks de diferentes orientações e locais de atuação, que formulam argumentos contrários à intervenção internacional no Haiti iniciada em 2004. Um exemplo de fôlego deste tipo de contribuição ao debate crítico é o trabalho do advogado e defensor de direitos humanos australiano Jason Macleoad, que publicou extenso ensaio intitulado From De-To-Post-To-Neo Colonization: A Brief History of Haiti's Occupations (2011). A Agência Adital organizou extenso volume intitulado Haiti por Si: a reconquista da independência roubada (2013), cujo prefácio é do ganhador do Prêmio Nobel da Paz Adolfo Pérez Esquivel. ${ }^{56}$ Outro exemplo hipercrítico, que alerta contra "a tentação imperial do Brasil" - que estaria fazendo sua primeira vítima com o Haiti por meio da MINUSTAH - é Joël León, que publica na página virtual da ONG Mondialisation: Centre de Recherce Sur la Mondialisation, do Canadá. ${ }^{57}$ Por sua vez, o renomado escritor uruguaio Eduardo Galeano posicionou-se até o fim da vida pela retirada das tropas do Haiti. Com a contundência habitual, ele questionava:

Até quando os soldados estrangeiros continuarão no Haiti? Eles chegaram para estabilizar e ajudar; porém, já se passaram sete anos e lá estão, desestabilizando esse país que não os aceita. A ocupação militar do Haiti está custando às Nações Unidas mais de oitocentos milhões de dólares ao ano. Se as Nações Unidas destinassem esses fundos à cooperação técnica e à solidariedade social, o Haiti poderia receber um bom impulso ao desenvolvimento de sua energia criadora. E, assim, se salvaria de seus salvadores armados, que têm certa tendência a violar, matar e contagiar com enfermidades fatais. O Haiti não necessita que ninguém venha a multiplicar suas calamidades. Tampouco necessita a caridade de ninguém. Como bem diz um antigo provérbio africano, a mão que dá está sempre por cima da mão que recebe. Porém, o Haiti, sim, necessita de solidariedade, de médicos, de escolas, de hospitais e de uma colaboração verdadeira que torne possível o renascimento de sua soberania alimentar, assassinada pelo Fundo Monetário Internacional (FMI), pelo Banco Mundial (BM) e por outras sociedades filantrópicas. (2011, s/p)

Espírito similar também é encontrado nas contribuições de Noam Chomsky

sobre o tema, que transita pela fronteira da produção acadêmica e a abertamente

\footnotetext{
${ }^{56}$ Como a autodescrição na contracapa da obra explica, "A ADITAL, Agência de Informação Frei Tito para América Latina, é uma iniciativa de comunicação criada para dar visibilidade ao pensamento e à ação dos que constroem cidadania em nosso Continente. Suas fontes de informação são movimentos sociais, indígenas, mulheres, Intelectuais, igrejas, grupos culturais, negros, jovens e minorias étnicas. Para isso a ADITAL dispõe de uma ampla rede de repórteres que vivenciam diretamente os eventos em seus países e se tornam, assim, um instrumento ético de integração e de solidariedade de nossos povos" (SANTIAGO, 2013, contracapa).

${ }^{57}$ Ler artigo em (acesso Junho/2028): https://www.mondialisation.ca/haiti-premiere-victime-de-la-tentation-imperiale-dubresil/5337637.
} 
militante. Em um longo artigo intitulado Humanitarian Imperialism: The new Doctrine of Imperial Right (2008), ele menciona as seguidas intervenções no Haiti como ilustrativas de seu argumento, além de caracterizar inequivocamente os eventos de 2004 como um golpe de Estado. Ainda que não usualmente incorporado aos estudos de Relações Internacionais, Chomsky (2008) apresenta uma análise consistente e com farta documentação, levando a crer que trata-se mais de uma barreira política do que propriamente acadêmica à sua obra. Curiosamente, sua hipótese vai na contramão dos estudos sobre segurança internacional no pós-Guerra Fria nas RI, já que apresenta mais continuidades do que rupturas com o padrão intervencionista norte-americano de outrora. Vale notar que o artigo de Chomsky (2008) aparece como prefácio no livro de mesmo título do analista político belga Jean Bricmont, cujo subtítulo é Using Human Rights to Sell War (2007). ${ }^{58}$

\section{Considerações finais}

Este capítulo situou a presente investigação nos debates acadêmicos em torno do projeto da paz liberal, dentro dos quais encontra-se a atitude "hipercrítica", conforme classificada por Paris (2002, p. 338), que parece a melhor equipada para o tipo de interrogação da MINUSTAH que esta tese busca fazer. Mostrou-se que mesmo esta vertente pode ter sua mirada crítica ainda mais sofisticada, a partir da descolonização de seus próprios métodos e posturas (SABARATNAM, 2013). Reconheceu-se a existência de uma nova e crescente vertente teórica, a Paz Hibrida, que possui características ambivalentes frente ao projeto da paz liberal. Em seguida, apresentou-se o diminuto volume de abordagens acadêmicas, no Brasil e no exterior, que problematizam as missões da ONU no Haiti, especialmente a MINUSTAH. Por fim, prestigiou-se a existência de críticas não acadêmicas, incluindo vozes da sociedade civil e da vida política cotidiana, sobretudo nas sociedades haitiana e brasileira, que articularam discursos contrários à missão e às consequências negativas que esta intervenção produziu.

Este apanhado de críticas à MINUSTAH e ao projeto da paz liberal no Haiti mostrou que está disponível uma variedade de abordagens epistemológicas, metodológicas e politicamente distintas uma das outras. Não obstante sua

\footnotetext{
${ }^{58}$ Para ler ao texto completo de Chomsky, ver (acesso em maio de 2018): https://monthlyreview.org/2008/09/01/humanitarian-imperialism-the-new-doctrine-of-imperialright/
} 
existência, elas não alcançaram o poder político necessário para interromper uma missão que durou 13 anos, mesmo sendo programada inicialmente para ter apenas seis meses. Algo ainda não explorado, mas que pode ser feito com mais visibilidade a partir de agora que a missão já encerrou-se e os silenciamentos diminuíram, é a apreciação crítica (ou hipercrítica) da MINUSTAH mediante o mergulho na problemática do Haitianismo. Como visto, esta sugestão chega a aparecer de passagem na literatura crítica à missão (SEITENFUS, 2014, p. 55) ou mesmo em uma excepcional reportagem (Dias, 2010), mas não recebe maiores desdobramentos, nem investiga-se o tipo de fonte historiográfica que sustentaria tal paralelo. Em ambos os casos, a historiografia citada pode ser objeto de revisão.

Por isso, a fim de preencher esta lacuna, a partir do capítulo 3 desta tese passa-se a interrogar a MINUSTAH a partir da ótica do Haitianismo no Brasil. O próximo capítulo, portanto, irá apresentar a produção historiográfica brasileira (e ocasionalmente de brasilianistas norte-americanos) e do pensamento social brasileiro em geral acerca das repercussões da Revolução Haitiana no Brasil e do Haitianismo, fenômenos geralmente amalgamados como se fossem um só. Em seguida, no capítulo 4, fontes originais de enunciações do Haitianismo e seus conceitos derivados serão trazidos, na sua maioria de jornais do Período Regencial do Império Brasileiro (1831-1840), a fim de mostrar os usos e agendas políticas a que tal fenômeno discursivo podia estar vinculado.

Como será visto, esta problemática envolvia jogos de linguagem mais complexos do que se supõe, pois faziam uma alusão liminar ao Haiti ao mesmo tempo em que a política avançada pouco ou nada tinha de relação com este país, servindo antes à agendas domésticas (e pessoais, por vezes) dos homens, brancos de diferentes setores da elite política imperial, incluindo até mesmo vozes contrárias à escravidão e o tráfico de seres humanos racializados como negros e negras. Em todo caso, operavam como práticas discursivas que, junto à outras, concorriam para garantir o controle e a gestão de populações subalternizadas racial, política e socialmente na sociedade escravista brasileira. Funcionavam, pois, como mecanismos disciplinares e biopolíticos desta forma específica em se desenvolveu a colonialidade do poder no Brasil. 


\section{CAPÍTULO 3: Historiografia brasileira do Haitianismo e da Revolução no Haiti}

As repercussões da Revolução Haitiana no Brasil são objeto de reiterado interesse da historiografia brasileira há pelo menos três décadas. Existe uma boa quantidade de trabalhos dedicados exclusivamente ao seu estudo, além de obras que tratam de outros temas na História do Brasil e acabam mencionando tais impactos. A cunhagem de um conceito como Haitianismo, em pleno século XIX, é frequentemente apontada como ilustrativa deste impacto no Brasil escravista.

Em geral, menciona-se, por um lado, a inspiração que a Revolução Haitiana provocou nos escravizados e na população negra em solo brasileiro em suas lutas contra a dominação escravista, branca e proprietária. Por outro, são destacados registros dos sentimentos de temor sociorracial que este exemplo haitiano teria provocado nos setores proprietários e brancos do recém-criado Império Brasileiro.

São discursos classificados como medo branco por Célia Maria de Azevedo (2004) em seu estudo seminal sobre o imaginário das elites imperiais no Brasil.

Neste capítulo, veremos de que forma tais narrativas sobre o Haiti (ou São Domingos) e sobre o Haitianismo são tratadas pela literatura disponível. Além de apontar que autores diferentes enfatizam aquilo que entendem como "repercussões" de uma forma própria, priorizando ora a inspiração, ora o medo, também será notado que a designação de Haitianismo parece abarcar fenômenos díspares, referentes à épocas e lugares onde este significante não esteve de fato presente de forma textual. O conceito de Haitianismo, por exemplo, só surgiria em 1831, mas é utilizado pela historiografia para designar eventos e fenômenos anteriores à sua cunhagem ou posteriores a seu ocaso. Poucos autores refletem sobre a rápida entrada em desuso do conceito, após intensa utilização que dura até cerca de 1835 ou 1836. Espacialmente, há uma tendência a afirmar a existência de "Haitianismo" em outras partes das Américas e do mundo atlântico quando, a rigor, textualmente, este neologismo somente foi produzido e cunhado no Brasil, levantando dúvidas sobre a sua utilização um tanto irrefletida por parte da literatura que o abordou.

No entanto, também há abordagens que, indo mais a fundo nos arquivos históricos, percebem o Haitianismo não simplesmente como repercussão de algo externo que chega ao Brasil, mas, principalmente, como mecanismo discursivo que se utiliza de alegorias internacionais, e racistas, para avançar agendas políticas 
domésticas e locais. Estas análises o entendem como parte dos atritos políticos cotidianos. Um dispositivo usado para avançar, ou prejudicar, carreiras pessoais, por exemplo. Trata-se de sua utilização para fins eleitorais, suspensão de direitos e de perseguição política na Corte Imperial durante a intensa disputa pelo poder no Período Regencial (1831-1840), principalmente em seus primeiros anos. Nesta visão, o Haitianismo é percebido como uma provocação racista nos embates políticos entre as elites intelectuais e políticas brancas, ou não negras, do Império Brasileiro, num dado momento histórico. Algo que acaba participando da produção discursiva da identidade nacional e racial do Brasil pós-colonial, segundo as vozes de sua nascente elite política e intelectual.

Há, portanto, baixo nível de consensos na literatura sobre Haitianismo e também sobre as repercussões da Revolução Haitiana no Brasil. Nesta pluralidade, também há trabalhos recentes que estabelecem pontes, mesmo que incidentais, entre o Haitianismo e a MINUSTAH, como veremos a seguir. Após revisar a produção bibliográfica disponível, será proposta uma maneira de compreender os temas e debates envolvidos nesta problemática, que envolvia, invariavelmente, dilemas de colonialidade e biopoder: uma das grandes questões enfrentadas era como gerir e reproduzir uma população não branca e escravizada a partir do momento em que entrava em vigor a primeira lei que colocava na ilegalidade o tráfico atlântico (1831), mas que também obrigava as elites intelectuais e políticas a se preocuparem com os desequilíbrios demográfico-raciais, tanto por motivos de segurança pública quanto de manutenção da economia primário-exportadora.

Ao fim, como forma de contribuir para o esforço historiográfico ainda em curso, serão apresentados alguns resultados da pesquisa empírica com fontes originais (sobretudo jornalísticas) do século XIX, de modo a aumentar o cabedal de exemplos em que o Haiti e a Revolução Haitiana são mobilizados pelos discursos políticos brasileiros. Contudo, nesta seção final somente serão apresentados os casos em que o termo Haitianismo não é empregado textualmente, uma vez que este ambiente discursivo será abordado, com detalhes, no capítulo 4.

\section{O Haiti e o Haitianismo como exemplo e inspiração}

O antropólogo e historiador Luiz Mott (1988) é uma referência nestes debates por conta de seu trabalho, considerado pioneiro, lançado ao público em 1981, A Revolução dos Negros do Haiti e o Brasil. Sua tese central é que "os negros 
no Brasil [escravista] estavam muito mais em contato com o 'mundo exterior' do que até então se supunha”, sendo que a inspiração provida pelo sucesso da luta no Haiti era exemplo desta comunicação, de sua agência e pensamento políticoestratégico, geralmente ocultadas pelas narrativas tradicionais, calcadas no "mito da falta de comunicação a que estariam condenados os negros no Brasil Colonial e Imperial” (MOTT, 1988, p. 11-13).

\begin{abstract}
Nossas pesquisas revelam exatamente o contrário: há provas incontestáveis de que houve sistemática comunicação entre os escravos residentes em diferentes fazendas, entre negros de uma capitania com os de outra, dos libertos e ingênuos do Brasil com os negros da África e de outras regiões do mundo escravocrata (...) [Em 1805] o Ouvidor do Crime mandara arrancar dos peitos de alguns cabras e crioulos forros, o retrato de Dessalines, Imperador dos Negros da Ilha de São Domingos. E o que é mais notável era que estes mesmos negros estavam empregados nas tropas da Milícia do Rio de Janeiro, onde manobravam habilmente a artilharia (...) arrancaram-se os anéis, mas ficaram os dedos, diríamos, pois a partir desta data várias são as referências tanto entre os brancos, como entre os negros, da revolução da ilha de São Domingos. Os primeiros temendo, os negros desejando. $(1988$, p. $11 ; 13-14)$
\end{abstract}

Ele segue adiante mencionando registros de episódios ocorridos em Salvador (1814), Recife (1817), Sergipe (1824) e Rio de Janeiro (1831) nos quais "os negros falavam abertamente de suas revoltas, comentando os acontecimentos do Haiti" (1988, p. 14-18). ${ }^{59}$ Desta última cidade, ele traz à luz um ofício do desembargador encarregado da Polícia da Corte em que presta contas ao ministro da Justiça acerca da busca por dois "pretos da ilha de São Domingos que desembarcaram no Rio de Janeiro", representando o "temor do 'contágio direto' de haitianos presentes em território brasileiro". ${ }^{60}$ Tais casos, ao fim, levam o autor a sugerir que "se estes dois haitianos eram de fato 'agitadores', cabe ao Haiti, antes de Cuba, a primazia de "exportar a revolução"” (1988, p. 18). ${ }^{61}$ Além de possíveis

59 Os documentos históricos apresentados por Mott (1988) serão amplamente citados pela historiografia que lhe sucedeu, como provas da influência da Revolução Haitiana no Brasil. Mott (1988), entretanto, não menciona a palavra Haitianismo em nenhum de seus achados ou em seu artigo pioneiro.

${ }^{60}$ A resposta da Polícia foi a seguinte, em 30 de maio de 1831: "Relativo aos pretos da ilha de São Domingos que aqui existem informo que ordenei ao Comandante da Polícia a sua apreensão. Conseguiu-se prender Pedro Valentim, que residia na Hospedaria das Três Bandeiras. Tenho continuado na diligência de apreender o outro, que consta ser clérigo e fui informado que foi visto ontem na Rua dos Latoeiros, em meio a muitos pretos, não sendo, porém, encontrado quando foi mandado prender" (Arquivo Nacional, cód. 324, fl. 35, citado por MOTT, 1988, p. 18).

${ }^{61}$ Para outra comparação entre os papéis paradigmáticos exercidos pelas Revoluções no Haiti e Cuba no continente latino-americano e caribenho, ver a geografia crítica de Porto-Gonçalves (2006), que batiza o medo da exportação da Revolução Cubana a partir de 1959 com o conceito de "novo haitianismo" (2006, p. 159; 181). Gomes e Soares (2002, p. 136) também fazem comparações semelhantes entre as duas ilhas revolucionárias. 
agitadores, também “temia-se o exemplo - 'o mau exemplo' - do Haiti pois esta revolução dos escravos produzia entre os negros do Brasil o estímulo e o paradigma para o questionamento do regime servil nacional" (1988, p. 16). Por isto, apesar de seu argumento priorizar a comunicação entre os subalternizados, Mott (1988) também dá destaque para a circulação discursiva do medo branco. Este temor é explicitado não apenas por autoridades brasileiras, mas também por documentos de época que trazem a fala de três agentes governamentais europeus de nacionalidades distintas (Portugal, Inglaterra e França), igualmente preocupados com a chance de surgir um novo Haiti em terras brasileiras, tema constante em tais discursos.

O exemplo da ilha de São Domingos é tão horroroso e ainda está tão recente, que ele só será bastante para aterrar os proprietários deste continente (...) Poderia resultar na expulsão dos brancos deste continente e no estabelecimento de uma segunda São Domingos nos territórios brasileiros (...) Então, toda a revolução acabará no Brasil com o levante dos escravos, que quebrando suas algemas, incendiarão as cidades, os campos e as plantações, massacrando os brancos, e fazendo deste magnífico império do Brasil uma deplorável réplica da brilhante colônia de São Domingos. (1988, p. 14-15)

Nesta trilha argumentativa aberta por Mott (1988), que destaca a ambivalência entre inspiração e medo sempre presente em tais representações do Haiti, historiadores como Flávio Gomes (2002) publicaram pesquisas sobre "ideias, temores e narrativas em torno do Haiti no Brasil Escravista" de modo a ressaltar os "significados locais" destas "experiências transatlânticas", acrescentando-lhes o termo "Haitianismo" para designar este conjunto de repercussões (2002, p. 209).

O fantasma do haitianismo atacava em vários lugares. Denúncias davam conta de um 'cafre haitiano', chamado Moiro, que estava convidando os escravos das vilas de Bananal, Areias, Barra Mansa e São João Marcos para se insurgirem, e que já havia cerca de sete mil cativos envolvidos neste plano. Exagero, certamente. Fato interessante é que o dito haitiano foi preso e "não negou" as acusações contra ele existentes, de que estaria convidando vários cativos para participarem de uma insurreição, "porém disse, que estava brincando". Brincadeiras ou não, o certo é que as autoridades pediram a expulsão deste haitiano do Brasil. O medo parecia cruzar fronteiras e mares. Temores dos malês baianos e o exemplo haitiano misturavam-se agora para significar um movimento internacionalista de sublevações escravas. (2002, p. 214)

Em conjunto com Carlos Eugênio Soares, o mesmo autor também chamou atenção para a comunicação internacional, ou transnacional, dos setores subalternizados em Sedições, Haitianismo e Conexões no Brasil Escravista: outras 
margens do atlântico negro (GOMES; SOARES, 2002).${ }^{62}$ Recorrendo a pesquisas de outros historiadores, eles aprofundam os argumentos originais de Mott (1988) sobre o duplo impacto do Haiti revolucionário no Brasil escravista. ${ }^{63}$ Flávio Gomes, novamente na companhia de outros autores, lança a obra Cidades Negras (2006), que traz, dentre outros objetos, descrições das tensões raciais nos centros urbanos do Império Brasileiro. Apesar desta passagem se referir aos anos 1830, os autores não empregam diretamente o termo Haitianismo desta vez. Mas sua agenda segue sólida no sentido de buscar nas narrativas sobre Haiti as mostras da agência política, intelectual e social da população percebida como negra - escravizada e não escravizada - na sociedade brasileira; de sua presença e importância frequentemente silenciadas pela historiografia tradicional.

É certo que temores de insurreições sempre dominaram as sociedades escravistas. Nas cidades, em algumas ocasiões, o medo transformou-se em epidemias pânicas. No Brasil, nas primeiras décadas do século XIX - sobretudo na década de 1830 -, as autoridades, políticos, jornalistas e senhores dialogaram muito, e também se afligiram, em torno das revoltas escravas e da sua aproximação dos centros urbanos (...) Para mentes amedrontadas, as imagens do levante escravo de São Domingos (posteriormente conhecido como Haiti) ganharam reforço na série de revoltas escravas de Salvador e do Recôncavo Baiano, principalmente a Revolta dos Malês em 1835. (ARAÚJO et al., 2006, p. 51)

O historiador José Maia Bezerra Neto (2001) realiza pesquisas com fontes primárias em seu bem documentado estudo sobre "protesto e fugas de escravos na província do Grão-Pará (1840-1860)”, dando o nome de Haitianismo para tais fenômenos. De acordo com ele, devido à proximidade com colônias francesas, pensava-se que a região Norte do Brasil possuía um maior potencial de contágio revolucionário direto. $\mathrm{O}$ medo branco é atestado pelas fontes policiais que ele

\footnotetext{
${ }^{62}$ Paul Gilroy (2001) usou a expressão atlântico negro no título de seu influente livro, que menciona, no prefácio à edição brasileira, paralelos entre o Brasil e o Haiti ao tratar da "resistência à escravidão" e ao sistema de comércio global ancorado neste "sistema da escravidão racial": "O Haiti é aqui, como diz a canção, e devemos lembrar que isto marcou o edifício da euro-modernidade de forma muito mais profunda do que se tem reconhecido" (2001, p. 11). Ver também a coletânea organizada por Laurent Dubois e Julius Scott, Origins of the Black Atlantic (2010).

${ }^{63} \mathrm{E}$ trazem mais fontes, por exemplo: "Em fins de 1836 as investigações rumariam para a freguesia da Candelária: na casa de Miguel Cerigueiro, na rua da Quitanda, estaria hospedado "um tal Emiliano suspeito de haitianismo". Aqui e acolá, avançando o século XIX, rumores de revoltas e de associações libertárias fariam redespertar o fantasma do "haitianismo". Em 1846 foi preso nas ruas de Recife o pastor negro Agostinho José Pereira, desertor militar que participara da Sabinada. Era acusado de fomentar uma "seita religiosa" e de estar envolvido com o planejamento de uma rebelião, mantendo contatos com outras províncias. Foram encontrados em seu poder alguns escritos em versos que falavam de "liberdade" e explicitamente do Haiti" (GOMES; SOARES, 2002, p. 138).
} 
apresenta, concluindo que "por meio dos fugitivos ligavam-se os mundos da escravidão existentes no Brasil, nas Guianas e no Caribe, fazendo ver aos senhores que o Haiti não era longe daqui” (2001, p. 82).

\begin{abstract}
Neste sentido, embalados pelas "amargas lembranças" da Cabanagem [18351840], o fantasma da revolução negra ressurgia sob o espectro do haitianismo. Em 1854, a chefatura de polícia comunicava ao presidente da província que a continuidade da inoperância das autoridades públicas e a "fuga em grande escala dos escravos" seriam as principais causas para que a tranqüilidade e a ordem pública estivessem "abaladas até seus fundamentos". Dizia ainda mais a correspondência policial acerca das fugas de escravos: “... esta planta a desolação por toda parte, e o receio em todos os corações, por ser tamanha a quantidade de negros fugidos, que se teme a cada instante nos venha acontecer o que aconteceu no Haiti”. $(2001 \text {, p. } 82)^{64}$
\end{abstract}

Outro influente historiador que usa o conceito de Haitianismo para denotar "um temor de longa duração a sobressaltar a alma do escravismo brasileiro" é João José Reis (2000, p. 250), especialista em movimentos de resistência à escravidão e ao racismo no Brasil imperial, principalmente na Bahia, palco de "um ciclo de revoltas e conspirações escravas durante a primeira metade do século XIX" (REIS, 2014, p. 69). Em suas obras, o Haitianismo também está carregado do mesmo duplo-significado, oscilando entre medo e inspiração, a depender da perspectiva dos sujeitos e forças sociais implicados.

O haitianismo se tornou a expressão que definiria a influência daquele movimento sobre a ação política dos negros e mulatos, escravos e livres nos quatro cantos do continente americano. O Brasil não ficou de fora (...). Talvez mais do que senzalas e barracos, entretanto, o Haiti penetrou, como um pesadelo, as casas senhoriais, os palácios governamentais e mesmos os clubs rebeldes brancos. Na conjuntura da descolonização no Brasil, várias vozes ligadas à ordem advertiram sobre uma reprodução aqui do fenômeno haitiano, caso as divergências entre portugueses e brasileiros se aprofundassem. (2000, p. 248-249)

Em mais de uma oportunidade, Reis $(1989 ; 1995 ; 2000 ; 2014)$ aborda os episódios que esta literatura expõe como exemplares do Haitianismo. Um deles é o famoso jantar dos "Mata-Caiados", na Vila de Laranjeiras, Sergipe, em 1824, onde vivia a maior colônia lusitana daquela província. Neste encontro subversivo, teria sido articulada a distribuição de panfletos na cidade com os dizeres "VIVAM OS

\footnotetext{
${ }^{64}$ Em outro artigo, o autor retorna ao tema: "Diversos historiadores vêm chamando a atenção em seus estudos sobre os mundos da escravidão, nos quais se inseria o tráfico, para a situação de medo das elites diante da possibilidade de revoltas escravas sob o espectro do haitianismo, bem como o temor de uma irreversível africanização do Brasil, que comprometesse seu potencial como civilização" (BEZERRA NETO, 2011, p. 177).
} 
MULATOS E NEGROS; MORRAM OS MAROTOS E OS CAIADOS”, em alusão à forma como eram chamados os portugueses e brancos, respectivamente. Um jornal enviado ao governador de Armas da região dizia, sobre o episódio:

Senhor Governador de Armas. ALERTA. Uma faísca faz um grande incêndio. O incêndio já vai lavrando. No jantar que deram nas Laranjeiras os 'Mata Caiados' se fizeram três saúdes: primeira à extinção de tudo quanto é do Reino, a que chamam de 'marotos'; a segunda a tudo quanto é Branco do Brasil, a que chamam 'caiporas'; a terceira à igualdade de sangue e de direitos. Que tal alerta e bem alerta. Um menino R........ irmão de outro bom menino, fez muitos elogios ao Rei de Haiti, e porque o não entendiam, falou mais claro: São Domingos, o Grande São Domingos. Não houve manobra. Vossa $\mathrm{Ex}^{\mathrm{a}}$ tome cuidado. Os homens de bem confiam em Vossa Exa . Só querem Religião, Trono e Sistema de Governo jurado no dia 6 de junho. Alerta. Alerta. Acudir enquanto é tempo. ${ }^{65}$

Em texto mais recente, Reis (2014) volta a abordar a possível influência "do modelo haitiano" na Revolta Escrava de 1814 na Bahia, discutindo se ela teria inspirações islâmicas ou se "teríamos um movimento haitianista" (2014, p. 86). Apesar de sua reticência quanto a ambas as hipóteses, ele lembra que os negociantes e "Cidadãos da Praça da Bahia"” enviaram uma representação à sua alteza real, d. João VI, na qual esta conexão é enunciada:

Aquela petição de protesto contra o conde dos Arcos comunicava ao príncipe regente d. João que os escravos baianos "falam e sabem do sucesso fatal da Ilha de São Domingos", aportuguesando o nome da antiga colônia francesa de Saint Domingue, conflagrada por uma revolução escrava em 1791, que depois de longo e sanguinolento processo terminou por proclamar a independência em 1804, adotando o novo país o nome de Haiti. $\left(2014\right.$, p. 85-86) ${ }^{66}$

No mesmo ano de 1824 também ocorreu outro episódio frequentemente citado pela historiografia brasileira do Haitianismo e da Revolução Haitiana, desta vez ocorrido nas imediações de Recife. A cidade vivia no clima de lutas pela implementação da Confederação do Equador, abertamente separatista frente ao recém-criado Império Brasileiro. Neste cenário, "soldados do batalhão de pardos saquearam lojas de portugueses e distribuíram pasquins contendo versos

\footnotetext{
${ }^{65}$ Este episódio também é descrito por Carvalho (1998), Gomes (2002, p. 213), Gomes e Soares (2002, p. 137), Nascimento (2008, p. 126) e pelo próprio Reis, em outros trabalhos (1995, p. 28; 2000 , p. 249), sendo que o primeiro a descobrir no Arquivo Nacional e expor tal documentação sobre o famoso jantar havia sido Mott (1988, p. 16-17).

${ }^{66}$ Luciana Brito (2008) estuda a legislação baiana do século XIX que versava especificamente sobre africanos, para quem era reservado o Rigor da Lei. "O medo do haitianismo, junto ao fato de a primeira metade do século XIX ser marcada por diversas revoltas na Bahia, suscitou o debate a respeito da questão da segurança naquele período" (2008, p. 39). Segundo ela, a elite política da Bahia acreditava que os africanos eram mais perigosos do que os escravizados nascidos no Brasil.
} 
haitianistas" (REIS, 2000, p. 249). Os versos são objeto de atenção de uma ampla gama de autores:

Qual eu imito a Cristovão

Esse Imortal Haitiano

Eia! Imitai ao seu povo

Oh meu povo soberano ${ }^{67}$

Um dos importantes autores que trata deste episódio é Clóvis Moura, com seu pioneiro estudo Rebeliões da Senzala (1959). Atento às fontes, ele, no entanto, não se refere a este episódio como Haitianismo, ainda que mencione a "inspiração haitiana [do] movimento" (1959, p. 106). Moura (1959) articula seu argumento unido discussões de raça, classe social e heranças culturais:

Os levantes dos escravos haitianos, que eliminaram praticamente os habitantes brancos daquele país antilhano e causaram pânico na Europa pela extensão de suas consequiências, tiveram ressonância no Brasil entre os escravos que lutavam pelo mesmo objetivo dos daquela ilha. Em 1824, um batalhão de pardos levantava-se em armas para tomar a cidade de recife de assalto. A ele aderem centenas de escravos dos engenhos. Seu líder é Emiliano Mundurucu que lançou aos pardos, pretos e ao povo em geral um manifesto originalíssimo em versos, onde reconhece a inspiração haitiana de seu movimento (...). Imediatamente após esse levante o Major Agostinho Bezerra enviou, a fim de dar combate àqueles escravos sublevados, um batalhão que frustrou pelas armas os intentos de Emiliano Mundurucu e seus seguidores. Os versos que formam a originalíssima canção pertencem hoje ao folclore da região. (1959, p. 106)

Investigando este e outros eventos similares, Luiz Gerardo Silva (2016) propõe que se deva dar mais atenção aos "afrodescendentes livres" no Brasil, pois teriam sido os mais impactados pela "Revolução de São Domingos" (2016, p. 209). Apoiando-se nas teorias sociológicas de Norbert Elias, ele mostra que a historiografia, tanto brasileira como estrangeira, possui o hábito de ilustrar com personagens que não estavam escravizados uma série de argumentos sobre a suposta influência da Revolução Haitiana sobre escravizados no mundo atlântico (no episódio acima mencionado, ele argumenta, neste sentido, que Mundurucu era

\footnotetext{
${ }^{67}$ O líder dos soldados rebelados era o capitão do Batalhão de Pardos, Emiliano Felipe Benício Mundurucu, suposto autor dos versos. O próprio João Reis reproduz tais versos em outros trabalhos (1995, p. 28), assim como Carvalho (1998), Freyre, (2004, p. 135), Gomes (2002, p. 213), Gomes e Soares (2002, p. 138), Moura (1959, p. 107), Nascimento (2008, p. 128) e Silva (2016, p. 230). Morel (2017) segue mais detidamente a primeira publicação dos versos, assim como a biografia de Emiliano Mundurucu, que chegou a visitar o Haiti em 1825, antes de estabelecer-se na Venezuela, foragido das autoridades brasileiras.
} 
um funcionário público). Para Silva (2016), os eventos em São Domingos serviram de inspiração mais para a luta contra "o preconceito racial" e a desigualdade de direitos civis e políticos para os "homens livres de cor", que seriam os únicos "haitianistas" no Brasil (2016, p. 232). Portanto, o Haiti serviria não como um exemplo de revolução, ou mesmo de abolição do regime escravista, mas de acomodação política e jurídica para o estrato social de não brancos livres que possuíam "forte coesão social" e aspiravam participar da vida democrática e representativa sem precisar fazer "nenhuma referência a sua "cor" ou raça" (2016, p. 223). ${ }^{68}$

Washington Nascimento (2008) é outro historiador que concentra no conceito de Haitianismo múltiplos significados possíveis que a invocação da Revolução Haitiana poderia trazer no Brasil do século XIX. Apesar de não apresentar pesquisa documental própria, ele faz um bom apanhado dos debates sobre o tema, captando a mobilização daquilo que chama de Haitianismo como uma "matriz de sentido" tanto para o "imaginário do medo" quanto para as "referências elogiosas à Revolução Haitiana" (2008, p. 129; 132; 135). ${ }^{69}$

Sua análise destaca-se por perceber as ambivalências dos usos e táticas das respectivas agendas políticas do Haitianismo. Assim, ele é capaz de perceber que o discurso de medo sociorracial também serviu, paradoxalmente, para avançar propostas antiescravistas, tema já investigado por Azevedo $(2004)^{70}$ e Morel (2005), anteriormente. Ao reconhecer a dupla-função política que tal retórica podia desempenhar, é capaz de contestar o ceticismo positivista de Rafael Marquese

\footnotetext{
${ }^{68}$ Há outras formas de abordagens sociológicas, menos afeitas aos modelos empregados por Silva (2016) cuja apresentação soa um tanto esquemática. A reflexão de Adalberto Cardoso (2008), por exemplo, feita a partir de uma sociologia histórica, foca na produção de "inimigos internos" pelas elites e classes dominantes no Brasil, ao longo do tempo, e relaciona o "temor de uma rebelião escrava nos moldes ocorridos no Haiti" com a "crescente rebeldia dos escravos na segunda metade do século [XIX]" (2008, p. 84-85).

${ }^{69}$ Sua definição de Haitianismo é quase idêntica à de Reis (2000, p. 248), ainda que nenhum dos atores sustente esta amplitude geográfica alcançada pelo termo com dados empíricos que a comprovem. "Haitianismo foi o termo que circulou pelos quatro cantos da América e que era usado para definir a influência da Revolução Haitiana sobre a ação política dos negros, mulatos, escravos e livres em todo o mundo atlântico" (2008, p. 127). Apesar deste referente nos setores escravizados, seu texto apresenta uma maior quantidade de enunciações dos impactos sobre a elite branca brasileira do que sobre a população negra e a escravizada.

${ }^{70}$ Ambos mencionam uma mesma obra, publicada em 1821 pelo "[t]alvez o principal difusor do conjunto de ideias que depois veio a ser chamado como "haitianismo" (...) João Severiano Maciel da Costa. Ele era brasileiro, marquês de Queluz, governou a Guiana Francesa entre 1809 e 1819, foi membro da Assembleia Constituinte (1823), ministro do Império (1823-24), presidente da província da Bahia (1825-6) e ministro dos Negócios Estrangeiros e da Fazenda (1827)" (Nascimento, 2008, p. 131-132). Para Costa, "apenas 'felizes circunstâncias' tinham impedido até aquele momento insurreições do tipo de São Domingos" no Brasil (AZEVEDO, 2004, p. 32-33).
} 
(2004; 2006), historiador que questiona a própria existência do Haitianismo, tratado como mero recurso retórico. Algo que não representaria sentimentos reais, sendo desprovido de maiores efeitos. Tal perspectiva é contestada por mais de um estudioso do tema, como o próprio Nascimento (2008, p. 133-134) e, especialmente, por Ferreira e Gomes (2008, p. 154-160). ${ }^{71}$

\section{0 "novo Haiti" e o Haitianismo como medo branco no Brasil}

O Haiti e o Haitianismo, por outro lado, também foram abordados pela historiografia a partir da ênfase nos seus impactos sobre as elites políticas, econômicas e intelectuais brasileiras. Geralmente, nesta vertente, encontra-se descrições elaboradas do medo branco sendo enunciado por vozes próximas aos aparatos estatal e midiático, produzindo, na maioria das vezes, discursos que almejavam o incremento de práticas repressivas, vigilantes e agendas centralizadoras de poder no Brasil imperial. São ilustradas, assim, técnicas do que chamar-se-ia de governamentalidade de "uma sociedade controlada pelos dispositivos de segurança" (FOUCAULT, 1979, p. 291-293), mas que, devido ao seu inevitável recorte racial, também são, ao mesmo tempo, expressões da colonialidade do poder (QUIJANO, 2005) à moda brasileira.

Nesta acepção, o Haitianismo também é usado como catalisador dos impactos da Revolução Haitiana no Brasil e pode ser visto, por exemplo, em obras da história diplomática. O embaixador Gonçalo de Mello Mourão (2009) dedica um capítulo inteiro de seu estudo sobre a Revolução de 1817 (em Pernambuco) a mostrar como a "influência e repercussão da revolução haitiana no Brasil foi muito maior do que a geralmente propalada" (2009, p. 169). Sua conclusão é que os expedientes discursivos constituintes daquilo que ele denomina Haitianismo serviram ao propósito de fortalecer as agendas políticas mais conservadoras de sua época, não sendo mencionado nenhum impacto sobre os movimentos populares, de escravizados ou negros.

\footnotetext{
${ }^{71}$ A agenda de Rafael Marquese $(2004 ; 2006)$ é suavizar a presença do racismo na formação da nascente elite política brasileira, conforme declarado em Berbel e Marquese (2007), quando tentam provar a ausência de raça no debate político constituinte de 1821-24 e nas Cortes de Lisboa. Nishikawa (2005), segue o mesmo raciocínio para concluir que, portanto, tampouco poderia haver Haitianismo. Para ele, "os historiadores tendem a aumentar a importância do Haiti sobre seus impactos em outros mundos" e, portanto, o "impacto foi mais ideológico do que real" (2005, p. 11). Para uma resposta às proposições de Marquese, acusado de "daltonismo social", que versa justamente sobre "o tema do haitianismo", ver Ferreira e Gomes (2008, p. 154-160).
} 
Aquele exercício de fato, embora brevíssimo, de uma democracia racial inaudita nos fastos do mundo de então somente poderia, aos olhos dos contemporâneos, ser avaliada com base no que ocorrera e ocorria no Haiti. O que ocorrera e ocorria ali era a derrocada não somente do sistema colonial, mas da estrutura política como concebida por todas as aristocracias, oligarquias e plutocracias de então. A Revolução de 1817, ao engajar a participação ativa, política, administrativa e militar de negros escravos e libertos e mulatos, indistintamente, ao lado dos brancos, ao proclamar alto e bom som que "deseja uma emancipação, que não permita mais lavrar entre eles o cancro da escravidão" e que não pode "acreditar que os homens por mais, ou menos tostados degenerassem do original tipo de igualdade", não poderia indicar, naquela época, aos que não lhe eram simpáticos, senão um caminho em direção ao haitianismo. Os partidários da Monarquia rapidamente compreenderam essa lição, e a república foi imediatamente associada àquela noção de barbárie igualitária. Deste modo, a revolta haitiana, filtrada pelos acontecimentos de 1817, interferiria profundamente na história do Brasil, contribuindo para o fortalecimento das hostes monarquistas e para a caracterização do espírito republicano como extremista e condutor à desestruturação social, política e econômica. (2009, p. 172)

Interpretação similar é aquela avançada por Heloísa Starling e Lilia Schwarcz (2015). Embora tratando-se de uma obra generalista de História do Brasil, as autoras dão destaque em mais de uma passagem para "o fantasma ameaçador da Revolta de São Domingos", que "continuava rondando a imaginação das elites escravocratas brasileiras": pois "quanto aos dirigentes brasileiros, passaram a temer o Haiti como ao diabo" (2015, p. 228). Isto serviria de "pretexto para várias medidas restritivas, entre elas um modelo centralizador de poder após a independência" (2015, p. 228-229). Ao tratar de eventos que remontam à chegada da família real portuguesa ao Brasil em 1808, as autoras revelam a retórica civilizatória envolvida neste tipo de discurso, onde o genocídio dos não brancos aparece como política pública normal:

O governo também lidaria com especificidades geradas pela presença e cultura dos africanos e dos diversos grupos indígenas espalhados pela colônia. Por exemplo, no dia 13 de maio de 1808 o príncipe regente, por meio de carta régia, ordenava ao governador de Minas Gerais que iniciasse uma guerra ofensiva contra os índios Botocudo. Chamando os nativos de bárbaros, canibais e praticantes de atos atrozes - "ora assassinando os Portugueses e os índios mansos por meio de feridas, de que sorvem depois o sangue, ora dilacerando os corpos e comendo os seus tristes restos" - d. João pedia a eliminação sumária do grupo; em nome da "civilização" e da proteção de "uma sociedade pacífica e doce". Havia ainda o medo de rebeliões negras, fenômeno que ficou conhecido como "haitismo", ${ }^{72} \mathrm{em}$ alusão à tomada da colônia francesa do Haiti pelos negros. Esse movimento teve a capacidade de exportar o medo (por parte das elites) e a esperança (para os escravizados). (2015, p. 187)

${ }^{72}$ Esta grafia parece ser um erro de digitação desta edição, não uma variação proposital ou documental do conceito. 
Apesar de mencionarem esta esperança, as autoras dão mais ênfase ao medo branco e aquilo que era feito em seu nome. Elas sugerem um olhar desde as vidas urbanas cotidianas para mostrar a penetração desta problemática na opinião pública branca da época: "[n]o século XIX, quando os periódicos ainda eram poucos, mas as fofocas, muitas, o Haiti frequentou as manchetes e as boticas - local dileto para difusão das últimas novas”. O efeito era a criação de um clima de insegurança, pois “como não existiam notícias objetivas, sobrava o temor", dizem. Nesta ótica, concluem que "[o] Brasil se inventou, assim, como um anti-Haiti: por oposição, éramos todos brancos, cristãos e civilizados" (2015, p. 229).

Este Imaginário das elites do século XIX foi estudado por Célia Maria de Azevedo (2004), que traz uma série de enunciações daquilo que conceitua como "medo branco" (2004, p. 15-26), nos quais a alusão ao Haiti é feita por discursos de figuras proeminentes do Brasil imperial. Seu estudo seminal tem como objeto principal as parcelas mais progressistas da elite, no que tangia à questão da escravidão. São discursos que formulavam argumentos "emancipacionistas" e, posteriormente, "abolicionistas", mas tendo como base a exploração do medo de uma revolução como a haitiana no Brasil (2004, p. 30). A historiadora não menciona, no entanto, o conceito de Haitianismo para designar tais referências ao medo branco representado pelos acontecimentos do Haiti.

Também caberia ao novo país outra herança, igualmente decisiva, para que se começasse a pensar na necessidade de extinguir a escravidão. Era o grande medo suscitado pela sangrenta revolução em São Domingos, onde os negros não só haviam se rebelado contra a escravidão na última década do século XVIII e proclamado a independência em 1804, como também - sob a direção de Toussaint L'Ouverture - colocaram em prática os grandes princípios da Revolução Francesa, o que acarretou transtornos fatais para muitos senhores de escravos, suas famílias e propriedades.

Ora, perguntavam-se alguns assustados "grandes homens" que viviam no Brasil de então, se em São Domingos os negros finalmente conseguiram fazer o que sempre estiveram tentando fazer, isto é, subverter a ordem e acabar de vez com a tranquilidade dos ricos proprietários, por que não se repetiria o mesmo aqui? Garantias de que o Brasil seria diferente de outros países escravistas, uma espécie de país abençoado por Deus, não havia nenhuma, pois aqui, assim como em toda a América, os quilombos, os assaltos às fazendas, as pequenas revoltas individuais ou coletivas e as tentativas de grandes insurreições se sucederam desde o desembarque dos primeiros negros em meados de 1500. $\left(2004\right.$, p. 29) ${ }^{73}$

\footnotetext{
73 Já no prefácio, assinado por Peter Eisenberg [1987], lê-se que mesmo na campanha abolicionista radical "tentava-se, deste modo, tranquilizar as pessoas amedrontadas como o espectro de um novo Haiti assombrando o Brasil" (AZEVEDO, 2004, p. 12). O mesmo autor sustenta, em outro trabalho, que no "Sul cafeeiro, especialmente em São Paulo, a burguesia emergente protelou a abolição até
} 
Por sua vez, o trabalho sobre $O$ Medo na Cidade do Rio de Janeiro (2014), realizado por Vera Malaguti Batista, dedica-se à investigação da produção de inimigos internos no Brasil a partir dos discursos de medo e suas consequências em termos de redução de direitos. Além de invocar repetidas vezes o "espectro da Revolução Haitiana” (2014, p. 25), ela traz à luz documentos do século XIX contendo menções textuais ao Haitianismo, que a autora percebe como um marco nos dispositivos de controle e exercício de "biopoder, que inseriu o racismo nos mecanismos do Estado" (2014, p. 176). Seu olhar advém da criminologia crítica inspirada no antipunitivismo de Michel Foucault. Ela compara os discursos de medo do século XIX com os do final do século XX em "perspectiva diacrônica", de modo a captar "as permanências histórico-culturais das fantasias de controle total” (2014, p. 21; 124). Em sua pesquisa empírica, Malaguti Batista (2014) encontra episódios não mencionados por outros autores. Neles, o Haitianismo é explicitamente vinculado a campanhas de medo, uma "combinação explosiva" que “ia produzindo terror" (2014, p. 190). Em muitos casos, todavia, tais campanhas também eram denunciadas com ceticismo e ironia por personagens que desconfiavam de seus propósitos, como o jornal conservador Pão D’Assucar indica:

\footnotetext{
Forão suspensas as garantias constitucionais pela Assembléia Provincial do Rio de Janeiro em virtude da existência do Haitianismo, que, segundo a Mensagem da mesma Assembléia, consta a todos (menos a nós) e que as doutrinas haitianas são aqui apregoadas com impunidade; que há na Corte sociedades secretas neste sentido; e que tem cofres para os quaes contribue grande número de sócios de cor, livres e captivos (...) Nada cremos mais pernicionso que a propalação dessas ideias de haitianismo. (Pão D'Assucar, 07/04/1835 citado por MALAGUTI BATISTA, 2014, p. 190 $)^{74}$
}

\footnotetext{
que a pressão dos escravos e abolicionistas ameaçaram uma repetição das experiências de São Domingos e dos EUA" (EISENBERG, 1983, p. 127). O livro de Azevedo (2004) cobre um período extenso do século XIX. Mesmo sem ser este seu foco, ela encontra alusões ao Haiti até em 1883, enunciadas por Sylvio Romero, crítico literário, promotor, juiz e deputado. "[E]le afirmava enfaticamente que 'o negro é um ponto de vista vencido na escala etnográfica', e por isso, por ser ele incapaz, não-civilizado, sem noção de liberdade, a escravidão deveria continuar até que tivesse sucumbido no terreno econômico pela concorrência do trabalho livre personificado pelo imigrante europeu. Sua grande preocupação era de que 'o Brasil não é, não deve ser, o Haiti”' (2004, p. 60).

${ }^{74} \mathrm{O}$ envolvimento ativo do periódico Pão D'Assucar nos embates discursivos em torno do Haitianismo será analisado com detalhes no próximo capítulo, com recurso direto às fontes primárias. Fica o agradecimento à Malaguti Bastista (2014) por abrir um novo caminho de pesquisas para esta tese ao indicar este jornal, que oxigena os debates sobre o tema, em geral feito em cima dos mesmos episódios, repetidamente comentados pela historiografia, que reproduz fontes secundárias.
} 
Este episódio também é debatido pelo historiador Marcos Andrade (2012). Ao estudar a imprensa do Período Regencial, em especial o jornal Aurora Fluminense, de Evaristo da Veiga, ele faz valiosas contribuições para o entendimento do Haitianismo. O caso acima mencionado pelo Pão D'Assucar, rival da Aurora Fluminense, chegou a gerar uma Mensagem ao Trono alertando sobre a disseminação das "doutrinas haitianas" no Rio de Janeiro, texto que foi publicado na íntegra pelo Aurora, porta-voz das posições liberal-moderadas (2012, p. 140). O autor sugere que a disseminação do termo Haitianismo poderia estar ligada a uma tática para consolidar o poder do Partido Liberal Moderado, em especial a reeleição do Regente Diogo Feijó naquele ano. Mas que, ao mesmo tempo, poderia ser “instrumentalizada por distintos grupos políticos" e recomenda "cautela" em sua interpretação:

O fantasma de "haitianismo", aludido acima, rondava o interior das casas-grandes,
dos principais núcleos urbanos com grande contingente cativo e pairava na mente
das autoridades policiais e também poderia ser instrumentalizada de acordo com
os interesses de distintos grupos políticos (...) Esse temor tendia a se agravar em
contextos de ousadia e rebeldia escrava, como aconteceu em Carrancas, Minas
Gerais, e em Salvador, na Bahia. Mas foi especialmente após a Revolta dos Malês,
em janeiro de 1835 , que as referências ao "haitianismo" começaram a ser
mencionadas com alguma frequência nas folhas da Aurora. A entrada constante de
cativos e a ilegalidade do tráfico após a aprovação da lei de 1831 e, sem dúvida, a
rebeldia escrava, contribuíram para que a lembrança da revolta de São Domingos
fosse associada aos rumores e às revoltas escravas que de fato ocorreram durante
as Regências. Mas essas associações tem que ser interpretadas com cautela, uma
vez que eram utilizadas pelos interesses políticos em disputa e o prelo constituía o
espaço mais que conveniente para difundir e fomentar boatos em torno da
instrumentalização dos cativos e/ou pardos e referências ao "haitianismo" (...) A
instrumentalização dos cativos ou a difusão do temor ao "haitianismo", em
momentos de disputa entre elites, não constitui nenhuma novidade, seja em
conflitos de caráter mais restrito, envolvendo as disputas locais, ou mesmo em
contextos mais amplos das rebeliões ocorridas na províncias, particularmente no
período das Regências. (2012, p. 139-140) Historiadores dedicados ao estudo do segundo-reinado (1840-1889) do Império Brasileiro, como Ricardo Salles (2012), também dão destaque para o "limite social da vida política” representado pela Revolução Haitiana (2012, p. 45). Ao concluir seu trabalho sobre aquilo que classifica como "hegemonia senhorial", no sentido gramsciano, da classe dos escravistas da Bacia do Paraíba do Sul, que imprimiram sua "direção moral e intelectual ao processo de construção do Estado Imperial" (2012, p. 43), ele destaca o papel jogado pela percepção brasileira sobre o Haiti revolucionário: 
Nas sociedades americanas da segunda escravidão, o limite social da vida política foi muito mais demarcado e inelástico. Inicialmente, ele foi representado pelos efeitos e pela experiência adquirida com a Revolução Haitiana. Prevenir e evitar novas revoluções escravas foram preocupações constantes em todas as sociedades que possuíam escravos. Naquelas em que a escravidão, no entanto, era a base do desenvolvimento econômico e do poder político e social, essas preocupações tiveram que conviver com a expansão da própria escravidão. As soluções encontradas para lidar com essa situação variaram. Em Cuba, a manutenção da escravidão acabou reforçando os laços coloniais. No Sul dos Estados Unidos, mecanismos legais restringiram a escravidão ao espaço claramente delimitado da não cidadania. No Império do Brasil, constitui-se a única classe escravista que enfeixou, completamente em suas mãos, o poder econômico e o poder político. (2012, p. 45)

Ainda sobre o estudo das elites imperiais, o estudo de referência segue sendo o de José Murilo de Carvalho (2014), onde menciona-se textualmente o Haitianismo em duas passagens significativas, porém desconexas. A primeira diz respeito à hipótese central do autor quanto às causas da manutenção da unidade territorial no Brasil, frente à fragmentação que ocorrera na América espanhola. ${ }^{75} \mathrm{~A}$ segunda passagem, no entanto, trata da década de 1830 e as preocupações com equilíbrio racial da população brasileira. Fala-se de Haitianismo em meio a temores de uma possível "guerra de raças". O autor não comenta esta sutil elasticidade semântica e temporal do conceito por ele empregado:

Um fator deve ser mencionado, a escravidão (...). Pode-se expandir o argumento e propor que a unidade da ex-colônia também favorecia a manutenção da escravidão por evitar uma possível justaposição de países escravistas e não escravistas, provocada por eventual fragmentação. De fato, testemunhos da época deixam claro que havia entre a elite receio de revolta escrava, tendo-se cunhado a expressão haitianismo, referência à violenta revolta dos escravos da colônia francesa de Santo Domingo. (2014, p. 18)

(...) Esse grande influxo, aliado às turbulências regenciais, causou as primeiras preocupações com o equilíbrio racial da população e com perigo de uma guerra de raças ou, como se dizia, com o haitianismo. A revolta escrava de 1835 na Bahia gerou grandes receios de uma réplica no Rio de Janeiro. (2014, p. 295)

As narrativas em torno do Haiti mobilizadas por figuras destacadas da política nacional durante o processo de independência do Brasil também são objeto da atenção de Décio Freitas (1978). Para o historiador, a opção por uma via menos belicosa do que na América espanhola se dava porque "não faltavam exemplos

\footnotetext{
${ }^{75}$ A tese de Carvalho (2014) coloca maior peso explicativo, como é sabido, na unidade de formação e instrução profissional da elite estatal brasileira, mas considera a hipótese do Haitianismo como "plausível", ainda que merecedora de "qualificações" (2014, p. 18-19). Como visto, esta posição é mais do que plausível para Schwarcz e Sterling (2015), assim como também é para Décio Freitas (1978).
} 
vivos dos perigos potenciais de uma guerra contra a metrópole" e que, "[p]ior que tudo, não se podia descartar a hipótese de que a guerra desse de si um novo Haiti” $\left(1978\right.$, p. 46) ${ }^{76}$

\title{
3. Obras clássicas e abordagens inovadoras
}

Importantes autores do pensamento social brasileiro se utilizaram da contraposição entre Brasil e Haiti para estabelecer teses influentes nos debates sobre a escravidão na História do Brasil. São análises que enfatizam a diferença, em vez das semelhanças, entre as práticas de escravizados e escravizadores em ambos os países. Talvez por isto não usem o conceito de Haitianismo. Caio Prado Jr. (1979), por exemplo, opõe Brasil e Haiti ao reforçar a existência do medo branco, tão frequentemente mencionado na literatura sobre o tema, apontando-o como importante fator que colocava o "sistema [escravista] em crise":

\begin{abstract}
Os escravos, apesar de sua massa que representa cerca de um terço da população total, não terão neste processo, ao contrário do ocorrido em situações semelhantes noutras colônias americanas, como por exemplo em São Domingos (Haiti), um papel ativo e de vanguarda. Acompanharão por vezes a luta, participarão debilmente de alguns movimentos, despertando aliás com isto grande temor nas demais camadas da população. Mas não assumirão via de regra uma posição definida, nem sua ação terá continuidade e envergadura (...) Contudo, mesmo esta débil participação e até, na falta dela, a simples presença dessa massa de escravos surdamente hostis à ordem vigente num momento de agitação e convulsão social, era o bastante para desencadear a crise do sistema servil e pôr em equação o problema da escravidão. (1979, p. 142-143)
\end{abstract}

Emília Viotti da Costa aborda a questão de maneira diferente em seu clássico Da Senzala à Colônia (2010), enfatizando as infinitas atitudes de protesto, individual e coletivo, dos escravizados na região cafeeira do Vale do Paraíba e suas consequências para o regime escravista no Brasil. A rebeldia contra o cativeiro e os senhores ganha destaque em sua análise, fartamente documentada com base em

\footnotetext{
76 O historiador elabora este ponto: "Cônscios desses perigos, os estrategos da Independência vacilavam em empreender a jornada emancipadora. Entre as "sinistras intenções" dos lusos, advertia Barbacena à José Bonifácio, em carta de Londres, figurava a de promover "o levantamento dos negros". O cônsul inglês Chamberlain achava que havia "perigo para toda a população branca". Mareschal, encarregado de negócios da Áustria, fala na população branca "atemorizada pelo espírito da população negra". Armitage, que respirou fundo a atmosfera da época, concluiu que na hipótese de uma "guerra sanguinolenta e duradoura... a parte escrava teria pegado em armas, e a desordem e a destruição teriam assolado a mais bela porção da América Meridional” (...) O historiador Oliveira Lima, apologista da escravidão e do Império, falou no receio que os escravos praticassem contra os senhores "represálias como as do Haiti" (1978, p. 46).

O mesmo autor também faz referência ao Haiti em obra posterior, sobre a Cabanagem (1835-1840), grande revolta do Período Regencial que abalou a província do Grão-Pará e adjacentes, no norte do Brasil. Ver: Freitas (2005, p. 218-219).
} 
registros policiais e judiciais. Ao se referir ao esgotamento da força política dos escravistas, já em fins do século XIX, a historiadora encontra propostas similares às de Azevedo (2004), ou seja, que instavam os proprietários a aceitar a transição para o trabalho assalariado como forma de evitar algo pior, como no Haiti.

À vista disto, apelava-se para os senhores: deviam convencer-se da necessidade de uma modificação profunda nos seus hábitos. Olhassem para o sucedido nas Antilhas, onde a emancipação evoluíra de maneira diversa, conforme as regiões: nas áreas em que os proprietários haviam colaborado, tudo se processa facilmente; onde houvera resistência, o trabalho ficara completamente desorganizado. (2010, p. 373-374)

Gilberto Freyre (2004, p. 136), por sua vez, discute as repercussões dos "acontecimentos revolucionários" do Haiti para sustentar sua conhecida tese acerca de uma "doçura maior" nas relações inter-raciais no Brasil, devido às características particulares que a colonização lusitana teve nas Américas e na África, que ficou conhecida como teoria do luso-tropicalismo (2004, p. 136). Embora a proposição acerca da suposta democracia racial brasileira não seja seu objetivo específico nesta obra, que trata do Nordeste ${ }^{77}$ Freyre (2004) provê argumentos para fundamentá-la ao fazer extenso argumento sobre por que as repetidas alusões ao Haiti, que ele mesmo registra, não desembocaram em nenhuma revolução no Brasil. Em outras palavras, para Freyre (2004), seria pela existência da democracia racial brasileira que o Brasil não virou outro Haiti. ${ }^{78}$

Sua análise merece ser lida com atenção, apesar do tamanho, pois é pouco mencionada ou mesmo ignorada pela literatura sobre ambos os temas (Democracia Racial e Haitianismo). Freyre (2004) desloca momentaneamente o foco de atenção sobre o medo branco, assumido como um dado inconteste, para o "ódio do escravo contra o senhor, do preto contra o branco", extraindo destas "atitudes psíquicas" a diferença que separaria Brasil e Haiti. O "hibridismo" brasileiro seria o fator determinante desta distinção:

É um ponto a se estudar com minúcia, a repercussão dos grandes movimentos de rebeldia dos escravos das Antilhas, sobre as diferentes áreas escravocratas do Brasil. Particularmente sobre as áreas de civilização açucareira mais intensa, como

\footnotetext{
${ }^{77}$ Cf. FREYRE, Gilberto. Nordeste: Aspectos da Influência da Cana sobre a Vida e a Paisagem do Nordeste do Brasil. São Paulo: Cortez, 2004 (originalmente escrito em 1936).

${ }^{78}$ Argumento que seria retomado posteriormente por Marquese $(2004 ; 2006)$ e Nikishawa (2005), como visto. Para uma crítica da agenda política e intelectual de autores acusados de fomentar uma "ideologia da benignidade" da escravidão brasileira, a partir de contraposições com o Haiti, ver Cardoso (2008, p. 84).
} 
o extremo Nordeste ou o Recôncavo. As duas grandes civilizações do açúcar na América - a das Antilhas e a do Nordeste do Brasil - tendo seguido atitudes psíquicas e sociais diversas com relação aos escravos africanos importados para as suas plantações de cana, tiveram entretanto problemas comuns em face do negro e do mulato; e não deixou de haver repercussão dos acontecimentos revolucionários verificados na França e nos Estados Unidos, em Haiti e em São Domingos, sobre o nordeste do Brasil.

A ideologia libertária da Revolução Francesa e da Revolução Americana chegou aos dois sistemas escravocratas - o das Antilhas e o do Brasil - pelos meios mais surpreendentes e mais sutis. No Brasil, até por intermédio dos padres. Mas sem encontrar nunca entre nós ambiente tão favorável ao ódio do escravo contra o senhor, do preto contra o branco, como o que encontrou naquela outra parte da América, onde a monocultura do açúcar igualmente separa a população em senhores e escravos: mas escravos e senhores mais distanciados socialmente do que no nordeste do Brasil.

O motivo para essa diversidade de ambiente, já se disse que foi principalmente a doçura maior do português com relação à gente de cor; o hibridismo em que se abrandou tão cedo a colonização do Brasil, mesmo onde ela foi mais aristocrática pela sua origem e pela distância social imposta pela técnica de reprodução de senhores e escravos, a brancos e homens de cor. Algumas das famílias mais nobres já se recordou que, no Nordeste, tomaram, desde os primeiros anos, sangue indígena; outras, mais tarde, até sangue negroide ou ilhéu como, segundo bons depoimentos estrangeiros e a despeito de cartas de branquitude triunfalmente citadas por cronistas ingênuos, a família de João Fernandes Vieira. E a verdade é que a política portuguesa no Brasil sempre foi neste ponto, mais humana que a inglesa ou a francesa nas Antilhas. (2004, p. 135-136)

Mais adiante, Freyre (2004) retoma a oposição com o Haiti. Agora, mobiliza este referente comparativo para expandir sua reflexão sobre "o negro ou o mulato do Nordeste" e os motivos de suas atitudes políticas eventualmente radicais, que não seriam explicadas por "ódio radical de raça ou de classe", mas por “desajustamento psicológico”. Brasil e Haiti são novamente contrapostos:

Não se pode generalizar sobre o negro ou o mulato do Nordeste, dando-o como elemento por excelência perturbador da civilização aristocrática do açúcar: o mesmo grande e violento revolucionário que foi em São Domingos, por exemplo. Ou que foi o negro ou o quase-negro no Haiti. Decerto ele foi, aqui, em muitos casos, um insatisfeito, um mal ajustado, dentro do sistema terrivelmente simplista de senhores e escravos. Mas não por ódio radical de raça ou de classe; por desajustamento psicológico, principalmente. Este é que fez dele um introspectivo, não só individual como social. E em alguns casos um rebelado. (2004, p. 140-141)

Nem Freyre (2004) nem as fontes de época que ele apresenta fazem uso da palavra Haitianismo textualmente. Ele também registrara enunciações do medo branco ao mencionar episódios de lutas populares que fizeram alusão ao Haiti, como o já citado levante liderado por Emiliano Mundurucu, em 1824. Como fonte primária, Freyre (2004) agrega uma carta, de 1819, do governador de Pernambuco 
aos seus superiores em Lisboa na qual o governante presta contas sobre medidas tomadas contra a revolução que irrompera dois anos antes naquela província. É feito um relato sobre a sublevação dos "corpos de mestiços e negros" que, liderados pelo capitão Pedroso, tomaram Recife militarmente por alguns dias, em 1823. Em ambas, o Haiti serve como ilustração do temor sociorracial:

\begin{abstract}
Não foram todos os negros, nem todos os mulatos os que tomaram o partido dos rebeldes e se uniram a eles; porém, dos homens destas cores, aqueles que abraçaram a causa dos rebeldes, abraçaram-na de um modo excessivo, e insultante, e fizeram lembrar com frequência aos moradores desta capitania as cenas de $\mathrm{S}$. Domingos. Os homens mais abjetos desta classe, os mesmos, mendigos, insultaram seus antigos benfeitores, seus senhores, ou senhoras, e se prometiam com todo o despojo à posse de uma senhora, como acontecimento infalível (...) “... as notícias dos sanguinolentos sucessos da ilha de S. Domingos, onde os escravos revoltosos haviam triunfado dos senhores, circulavam amplamente comentadas e a muitos sorria a esperança da próxima desforra dos oprimidos com o estabelecimento entre nós de um regime análogo, sob os auspícios do prepotente governador de Armas", isto é do capitão Pedroso. (2004, p. 132; 134)
\end{abstract}

Tais alegorias de medo cuja referência é o Haiti não alteram, contudo, a perspectiva de Freyre (2004) sobre a diferença fundamental entre o Brasil e o país caribenho. Mesmo diante de tais enunciações do temor da repetição revolucionária, ou das seguidas analogias com o Haiti, o autor segue firme com sua proposição acerca de uma especificidade brasileira, positivamente valorada, sobre este tema. Haveria aqui uma técnica, ou tecnologia social, de gestão das diferenças sociais e raciais que seria superior à de lugares como o Haiti e os EUA. No Brasil, as relações raciais teriam origem numa escravidão com um grau comparativamente maior de doçura, mestiçagem e intimidade de relacionamentos entre as raças e classes sociais, acarretando em menor conflitividade sociorracial na era pós-colonial. ${ }^{79}$

Mais recentemente, o Haitianismo foi objeto de usos inovadores no pensamento social brasileiro. O geógrafo Carlos Walter Porto-Gonçalves, por exemplo, recupera o conceito e sugere ampliá-lo para novas temporalidades e espacialidades. Adepto das teorias decoloniais latino-americanas, ele trata do Haitianismo na apresentação à edição brasileira do famoso volume editado por

\footnotetext{
79 Para uma genealogia dos debates sobre a suposta democracia racial brasileira, ver Andrews (1997). Escapa ao apanhado deste autor, no entanto, que esta linha de argumentação de Freyre (2004) já havia sido desenvolvida cerca de cem anos antes, por volta de 1835, por intelectuais e políticos do Partido Liberal Moderado, como Evaristo da Veiga e Joaquim Candido Meirelles, analisados com detalhe no capítulo 4 .
} 
Edgardo Lander (2005) sobre a colonialidade do saber, assim como na obra de Ana Esther Ceceña (2006) sobre os desafios das emancipações em um contexto militarizado. Em ambas as oportunidades, Porto-Gonçalves $(2005,2006)$ traça um paralelo entre sua leitura do Haitianismo no século XIX e as políticas anticomunistas do século XX.

Ao contrário dos livros de história que, eurocentricamente, falam da história da liberdade a partir da Revolução Francesa ou da Revolução Americana ou, ainda, dos pressupostos do Iluminismo, foi no Haiti que, pela primeira vez, tentou-se a liberdade para todos, independentemente de se ser branco e europeu. Thomas Jefferson e Napoleão, assim como toda a elite crioula na América, tiveram tanto medo do haitianismo como, mais tarde, seus descendentes teriam do comunismo. (2005, p. 12)

Nesse contexto, o Haiti era um mau exemplo a ser confinado à ilha e se tornaria, na leitura dos brancos, uma ideologia perigosa, o haitianismo (...) A exacerbação dos nacionalismos coloniais nos anos 50 e 60 na Ásia, na África nos daria, na América, Domingo Perón, Getúlio Vargas, Jacobo Arbenz, a Revolução Boliviana de 52 e, em Cuba, em 1959, uma nova 'revolução impossível'. A partir daí o espectro do haitianismo de novo passa a nos rondar, agora sob o nome de comunismo. (2006, p. 158-159 - itálico no original)

Este uso inovador do conceito de Haitianismo é deveras pertinente, sendo ensaiado também por autores como Morel (2017). É inegável que ambas práticas discursivas estão relacionadas com políticas de medo, contenção (prévias) de revoluções sociais e movimentos populares. Mais ainda, há paralelos significativos entre os climas de perseguição e tecnologias de poder, como o estímulo a delações, disseminação de rumores que justificassem a escalada repressiva, assim como o uso eleitoral de tais expedientes (sem contar na sua mobilização para suspender processos eleitorais, instalando estados de exceção). Tamanha similaridade faz Porto-Gonçalves propor a expansão conceitual em direção ao "novo haitianismo":

As ditaduras militares de direita, em grande parte apoiadas pelos EUA, que já vinham se ensaiando contra o novo haitianismo cubano pelo menos desde 1964, no Brasil, iniciarão, em 1973, a primeira experiência neoliberal de que se tem notícia sob o massacre da experiência democrática e socialista do Chile por Augusto Pinochet (...) O primeiro momento do processo de crescimento das aglomerações sub-urbanas da região, nos anos 1950/60, foi experimentado pela população em meio a governos populistas, muitos de corte nacionalista, que, desde a revolução cubana e o medo do novo haitianismo que se seguiu, serão objetos de enormes pressões. (2006, p. 159; 181 - negrito adicionado)

No entanto, esta proposta conceitual, apesar de fecunda, difere daquela que será apresentada no capítulo 6 desta tese em um aspecto fundamental: a relegação 
da questão racial para um segundo plano neste neo-haitianismo de Porto Gonçalves (2006). Curiosamente, ele opera uma desracialização do conceito ao mesmo tempo em que invoca a colonialidade do poder como referencial teórico. Mas para Aníbal Quijano, "a ideia de raça é, com toda certeza, o mais eficaz instrumento de dominação social inventado nos últimos 500 anos" e nisto reside a sua "colonialidade, que se constituiu como a pedra fundamental do padrão de poder mundial capitalista, colonial/moderno e eurocentrado" (QUIJANO, 2000, p. 192).

Por isso, a inovação espaço-temporal de Porto-Gonçalves (2005, 2006) consegue captar parte do potencial heurístico do Haitianismo, mas acaba abrindo mão de um componente central. No capítulo 6 desta tese, será proposta uma análise do Haitianismo que também o traz para o presente, mas, desta vez, mediante uma genealogia que enfatiza sua reativação como tecnologia de poder voltada para o controle e regulação (incluindo o extermínio) de populações identificadas discursivamente como não brancas. Estas duas estratégias analíticas não são, contudo, mutuamente excludentes, podendo ser combinadas de modo promissor. ${ }^{80}$

\section{4. $O$ conceito de Haitianismo textualmente analisado}

A historiografia brasilianista norte-americana também abordou o tema do Haitianismo. E o fez diretamente, pesquisando documentos com sua evocação textual e propondo interpretações engenhosas. O melhor exemplo é Thomas Flory (1977). Em Race and Social Control in Independent Brazil, o historiador analisa as consequências deixadas pela maneira como se tratou a questão racial nos "anos formativos" do país independente (1977, p. 200). Ele sugere que, no início da década de 1830, experimentou-se uma repentina discussão pública sobre raça no Brasil, no bojo da crise política que levou à abdicação do imperador d. Pedro I em 7 de abril de 1831. Mais ainda, sua pesquisa com fontes primárias o leva a perceber que setores importantes da população branca estavam participando com afinco destas aguerridas discussões que marcaram a abertura dos conflitos políticos do Período Regencial (1831-1840). Neste período, conforme notado pelo autor, o

\footnotetext{
${ }^{80}$ A possibilidade de tal combinação é reforçada pelo fato de Porto-Gonçalves (2005) também tratar das intervenções internacionais no Haiti a partir de 2004, logo na continuação da passagem sobre o Haitianismo: "Se tanta festa se fez em, 1992, para comemorar os 500 anos do 12 de outubro de 1492; em 1976, os 200 anos do 4 de julho de 1776 e, 1989, os 200 anos do 14 de julho de 1789, os 200 anos de 1804 haitiano passou sem comemoração. Ou, pior, ali estavam, em 2004, as tropas estadunidenses para, com apoio da França e do Canadá, aplicar um coup d'etat de velho estilo, apeando do poder o presidente eleito na terra de Toussant L'Ouverture”' (2005, p. 12).
} 
conceito de Haitianismo seria forjado e usado amplamente. Mas, com relativa rapidez, caído em desuso.

É interessante notar que em seu estudo, onde o conceito de Haitianismo é encontrado textualmente em diversos documentos históricos analisados, nenhuma referência direta é feita ao Haiti ou à Revolução Haitiana, nem às suas possíveis repercussões ou impactos no Brasil. O tema de fundo deste debate racializado, acertadamente identificado por Flory (1977), era a "questão do nativismo" (1977, p. 206), ou seja, relativo à produção de concepções sobre a identidade nacional. Junto a este, agregavam-se outros temas relativos à políticas domésticas, desde a luta pela nomeação de cargos na burocracia estatal até a própria definição do regime de governo (monárquico ou republicano), ainda em disputa por distintos grupos políticos em luta pelo poder estatal no Período Regencial (Liberais Moderados, Liberais Exaltados e Restauradores). Nesta acepção, mais do que alusões à Revolução Haitiana em si, o Haitianismo significaria uma "provocação racista" para fins políticos locais e imediatos, podendo ser mobilizado por afiliações políticas variadas e até mesmo opostas.

In 1835 some Exaltado journalists accused Evaristo da Veiga and the Moderados of themselves inventing the Haitianism scare as a political tactic to gain white votes. And a more conservative sheet of 1833 advanced as a pet theory of its own that the Moderado government had been duped by the English into feigning a fear of Haitianism in order to drive foreigners and natives into conflicts which would eventually 'depopulate Brazil and ruin Portuguese commerce so that [England] may introduce Irish merchants and colonists'. Clearly, the race issue was made to serve many masters. (1977, p. 212 - itálico no original)

Sua análise de periódicos do Período Regencial leva-o a concluir que a retórica racial e as "provocações racistas" que criaram o termo Haitianismo coincidiam amplamente com as "crises internas do mundo político branco" (1977, p. 210). Mais ainda, o autor percebe como o Haitianismo é chave para o entendimento das "atitudes complexas" da elite política brasileira quando se tratava de explicar o tratamento discriminatório contra negros livres mesmo sob um regime político nominalmente liberal (1977, p. 199). Apesar de reconhecer que existem “dúvidas a respeito da origem do Haitianismo" (1977, p. 212), ele acerta novamente ao identificar o receio que a racialização explícita do debate político gerava em figuras como Evaristo da Veiga, "o mais respeitado liberal [moderado] da época”, 
conforme o classificou José Murilo de Carvalho (2014, p. 295) em sua própria menção ao Haitianismo. ${ }^{81}$

Flory (1977) conclui que o Haitianismo deixou de circular no léxico político brasileiro após a Revolta dos Malês em 1835, episódio que teria tornado demasiadamente reais os discursos sobre medo sociorracial que vinham sendo invocados com frequência até então. Ele sugere que a entrada em desuso do Haitianismo e das provocações racistas a que servia marcariam uma nova era no modo das elites políticas brasileiras debaterem o controle social dos negros e demais não brancos. A partir deste momento, segundo Flory (1977), optar-se-ia, de modo geral, por uma retórica racial mais cautelosa e cuidadosa - menos inflamatória ou explicitamente racializante - gerando o ocaso do Haitianismo e dispositivos conexos.

Jeffrey Needell (2006), no entanto, discorda frontalmente de Flory (1997) justamente neste ponto sobre Haitianismo, tema abordado brevemente em seu estudo sobre aquilo que chama de $O$ Partido da Ordem no Brasil imperial. Embora reconheça o mesmo sumiço do termo Haitianismo das páginas da imprensa política e dê destaque aos usos para fins de politicagem eleitoreira, sua conclusão aponta para mais permanências do que mudanças na mobilização discursiva dos temores raciais e escravistas após 1835. Ele sugere, ademais, que o Haitianismo seguiu sendo mobilizado na década de 1840, mesmo que fora da imprensa, na forma de rumor oral, novamente para fins eleitorais (ainda que ofereça apenas um exemplo disto, por ocasião da Revolta Liberal de 1842, em Minas Gerais): ${ }^{82}$

Flory claimed that the disappearance of racialized political discourse derived from the 1835 revolt, as alluded to in n.73, above. As already stated in that note, he supplies no direct evidence for this (...) Although Haitianism may have been leeched out of the political press after 1835, the concern, as Barman notes, survived through the 1840's. Paulino noted the Luzia's appeal to gente de cor (people of color) in the Liberal Revolt of 1842, an appeal based on spreading the rumor of plans to reduce them to slavery. Rocha reported being slurred with the accusation

\footnotetext{
${ }^{81}$ Flory diz: "This is not to suggest that Evaristo da Veiga and his followers believed that the mulatto press was trivial because it was a managed tactic rather than a groundswell. Certainly they worried a great deal about the damage that such irresponsible stirring of racial tensions could do, and as the years passed their worry deepened. What was described rather mildly as the 'intrigue of colors' in 1832 had been labelled the much more portentous 'Haitianism' by 1835 ” (1977, p. 210). No próximo capítulo, analisaremos diretamente as palavras de Evaristo da Veiga a respeito do assunto, assim como as acusações sobre sua suposta autoria e responsabilidade pela cunhagem do conceito de Haitianismo em 1831.

${ }^{82}$ Também deve-se notar que no glossário ao final de seu livro, Needell (2006) define "Haitianism" como "advocacy of a Haiti-style revolt", mesmo que seu argumento mostre que os usos do termo excediam tal definição (2006, p. 450).
} 
of Haitianism that same year, in an effort to destroy his electoral ambitions (...) The point remains, tough, that neither Haitianism nor the fear of slave rebellion has been shown to be of such pervasive importance as to move slaveholders against the African slave trade. (2006, p. 377)

Este olhar mais detido sobre os usos cotidianos do conceito de Haitianismo no próprio século XIX e as formas em que foi de fato empregado por cada agenda política que o mobilizou textualmente é muito relevante, ainda que não tenha sido priorizado pela maior parte da historiografia brasileira, mais interessada em elencar aquilo que percebia como ecos, repercussões, impactos, influência, recepções, ou reações à Revolução Haitiana no Brasil escravista. Somente recentemente começase a fazer outros tipos de indagações a seu respeito. Um novo estudo, atento e de fôlego, foi publicado pelo historiador Marco Morel em 2017, sob o título de $A$ Revolução do Haiti e o Brasil escravista: o que não deve ser dito. Este livro propõe uma análise do tema a partir de uma perspectiva que enfrenta a complexidade do objeto, rompendo com a dicotomia estruturante dos debates historiográficos que variavam entre os binarismos repúdio/repetição ou medo/inspiração provocados pela Revolução Haitiana no Brasil (2017, p. 21; 25).

Ao discutir o Haitianismo, Morel (2017) faz uma distinção importante entre "o conceito de época" e a "categoria analítica historiográfica", diferenciação poucas vezes percebida ou vista como relevante pelos analistas que o precederam. ${ }^{83}$ Ele sustenta, ao revisar documentos do século XIX, que o conceito de Haitianismo, surgido apenas em 1831, serviria a um propósito “acusatório" e tinha "característica pejorativa"; ao passo que boa parte dos historiadores tenderam a usá-lo num sentido "elogioso", a fim de destacar a "exemplos de protagonismo de trabalhadores escravizados" (2017, p. 22-24). Para o historiador, estes "dois significados - o conceito de época e a categoria analítica historiográfica - ainda se mesclam e pode-se considerar que estão fadados a conviverem, nem sempre harmoniosamente" (2017, p. 23). Desta forma, ele destaca-se frente à historiografia anterior por perceber que "o nó da questão se desloca" nas diferentes mobilizações discursivas

\footnotetext{
${ }^{83}$ Borba de Sá (2016), trabalhando em separado, já chamara atenção para esta disjunção durante apresentação de resultados de sua pesquisa de doutorado em congressos acadêmicos. A coincidência com Morel (2017), neste ponto, deve-se ao fato, possivelmente, de que os arquivos da era imperial estão mais acessíveis atualmente em função de avanços tecnológicos importantes em anos recentes, com a digitalização das bases de dado. Além disto, o atual contexto histórico dos autores, marcado pela presença de tropas brasileiras no Haiti, junto com o retorno de narrativas sobre o país caribenho ao debate político nacional, podem ter concorrido para propiciar um interesse semelhante na análise dos usos de referências ao Haiti no discurso político brasileiro.
} 
do Haitianismo, ao longo dos séculos, por diferentes vozes: “O contexto altera o texto" (2017, p. 23), diz.

Há um ponto importante para esclarecimento. Qual a definição de "haitianismo"? Este neologismo (com o perdão da rima) tem dois principais significados na história do Brasil. Em primeiro lugar, cronologicamente, foi uma expressão de época. Haitianismo (e seus derivados) tinha um sentido acusatório e fazia parte da lógica de medo e ocultação: a palavra passou a existir no Brasil no ano marcante de 1831, especialmente na Bahia e no Rio de Janeiro, e não era inocente. Antes do vocábulo, tais inculpações já existiam. Embora repetido à exaustão na imprensa, no Parlamento, em conversas particulares e até em processos judiciais, o termo não chegou a frequentar dicionários. Tinha característica pejorativa: indicava o incitamento à rebelião dos escravos, apontava uma iminente ação destruidora e violenta da ordem social e política, de conotações raciais, visando desqualificar adversários, em geral, inocentes de tais acusações. Associava automaticamente republicanismo, antirracismo, crítica à escravidão e abolicionismo, na intenção de enfraquecê-los. Ou seja pode-se dizer que, nesta linha, haitianismo tinha uma acepção anti-haitianista, paradoxalmente. Assumir explicitamente a condição de haitianista no Brasil da primeira metade do século XIX era um crime hediondo, pelas leis e pelos costumes predominantes. $(2017 \text {, p. } 22-23)^{84}$

Refletindo sobre seu próprio contexto histórico e motivações para abordar o tema, Morel (2017) menciona a MINUSTAH, de forma crítica. Ele destaca o retorno, em pleno século XXI, da prática de se disseminar rumores racializados envolvendo o Haiti, de modo a mobilizar o medo racial para fins políticos e eleitorais na sociedade brasileira. Além de conectar o estudo do Haitianismo com a interrogação da MINUSTAH, o autor sugere haver uma "mentalidade de larga duração quanto a rumores de Haitianismo (2017, p. 19):

Cabe assinalar que parte deste trabalho foi elaborada em momento peculiar: a presença militar brasileira no Haiti desde 2004. Embora fuja do recorte temático e do período escolhidos, tal episódio e seus significados compõem o tempo presente do historiador. Ainda que sob o manto discursivo de "ajuda humanitária" e combate ao "caos", a atuação militar brasileira no país caribenho, com o maior contingente na Minustah (United Nations Stabilization Mission in Haiti), teve, como motivação central as aspirações do Brasil em obter uma vaga permanente no Conselho de Segurança da ONU. Agindo como força auxiliar dos Estados Unidos (que, junto com a França, participou diretamente da intervenção que depôs o presidente eleito

\footnotetext{
${ }^{84}$ Sobre os usos do conceito pelos historiadores, ele enxerga novos propósitos e motivações: “Outra significação de haitianismo, desta vez tendencialmente positiva, surge na historiografia brasileira de fins do século XX e começo do XXI: indica a disposição dos protagonistas de seguirem (ou não) o exemplo da Revolução do Haiti. Evidentemente, sem a carga acusatória da época, mas trazendo questões que envolvem, em última instância, qualificações. O nó da questão se desloca. Ultrapassado um século da Abolição oficial da escravidão no Brasil, não é mais o embate direto em torno das transformações (ou não) de uma sociedade escravista, mas, agora, trata-se de empreender esforços interpretativos para dimensionar os sentidos e as heranças do escravismo na sociedade nacional" (2017, p. 23).
} 
Jean-Bertrand Aristide), o Brasil ajuda a manter não só a uma situação de excepcionalidade institucional como a controlar uma população majoritariamente pobre e miserável. A tentativa de legitimação desta atividade recebeu, inclusive, uma pitada de marketing através da promoção do futebol brasileiro (...) Em tal contexto, houve (e ainda há) um contingente expressivo de haitianos buscando refúgio no Brasil, legal ou ilegalmente. Foram recebidos de maneira desigual: algumas vezes tiveram a entrada proibida no país, em outras foram oficialmente bem-vindos, como na decisão do governo federal em setembro de 2015, quando se convocou abertamente a vinda dos haitianos ao país. O que gerou um rumor (ainda existem no século XXI, pelas "redes sociais" e além delas) de que o governo "comunista" (?) estaria formando um exército de 20 mil soldados haitianos no Brasil. Rumor que só pode ser encarado como humor, de mau gosto - expressando mentalidade de longa duração quanto a rumores de hatianismo no século XIX. (2017, p. 18-19)

Apesar destas considerações, Morel (2017) opta por seguir o caminho tradicional construído pela historiografia brasileira, no sentido de usar o conceito de Haitianismo para designar toda sorte de fenômenos e eventos que envolveram alguma alusão à Revolução Haitiana no Brasil escravista, mesmo aqueles ocorridos antes de 1931, quando ele mesmo verifica que o termo surgira. E segue fazendo-o para eventos posteriores à entrada em desuso desta prática discursiva peculiar. Tal uso expansivo deste conceito por Morel (2017), no entanto, é uma escolha consciente e cuidadosamente explicada pelo autor, diferentemente da literatura anterior que, em geral, repete tais equivalências de maneira irrefletida. Deste modo, sua análise ajuda a refinar a visão sobre o Haitianismo no Brasil. "Daí ser compreensível constatar que a historiografia brasileira ainda não tratou devidamente do tema" (2017, p. 25).

Quando discute as mobilizações textuais do conceito de Haitianismo, a distinção volta a aparecer, tornando nítidas as agendas políticas que, na visão do autor, estavam ligadas à sua produção e difusão discursiva. Ao fazê-lo, Morel (2017) é dos poucos a investigar a fundo a ação e os embates concretos em que se envolviam os protagonistas que de fato mais manipularam o conceito em sua época particular, chegando a apresentar uma hipótese própria sobre o episódio e as personagens envolvidos em sua criação originária. ${ }^{85} \mathrm{O}$ seguimento de disputas

\footnotetext{
${ }^{85}$ Para Morel (2017), o Haitianismo, como conceito, surge no bojo de uma discussão pública sobre raça entre dois jornais de Pernambuco (Astréa e Abelha Pernambucana), que se apropriaram de um episódio ocorrido em Junho de 1831 na Santa Casa de Misericórdia do Rio de Janeiro, quando registrara-se acalorado embate público entre dois de seus cirurgiões acerca da separação espacial racial entre os pacientes do hospital. Por defender a não divisão entre os doentes com base em sua cor de pele (e por ser ele mesmo um não branco, autodeclarado como "mulato"), o médico (e político) Joaquim Cândido Soares Meirelles foi acusado por um colega de fazer parte de uma
} 
pessoais e políticas serve de base para seu argumento social mais amplo, que entende a cunhagem de um conceito como Haitianismo como fruto de uma reação conservadora a um possível avanço progressista na questão da escravidão e do fim do tráfico.

Nesta visão, o termo haveria surgido no bojo do refluxo político capitaneado pelo projeto de poder do Partido Moderado, aprofundado com abdicação de d. Pedro I em 1831, ano em que, além da derrubada do monarca, aprovar-se-ia a primeira lei proibitiva do "infame comércio" de seres humanos escravizados (2017, p. 259). O Haitianismo serviria como um dispositivo de contenção de agendas consideradas demasiadamente radicais, proposição já defendida, como visto por Schwarcz e Sterling (2015) e Mello Mourão (2009).

Reiteradamente, entretanto, ele insere tal problemática no conjunto geral das “repercussões da Revolução do Haiti no Brasil" (2017, p. 258), mesmo diante das evidências em seu texto que mostram, pelo menos no caso do conceito específico do Haitianismo, usos e abusos cujas forças motoras parecem advir mais dos embates políticos domésticos e locais, do que de uma influência vinda do exterior. Esta postura o faz, inclusive, postular, após ressalvas metodológicas, a existência de um "modelo haitiano" em disputa com outros modelos de se fazer a independência e a construção do Estado e da nação no Brasil (2017, p. 27). A despeito disto, o autor enfatiza a "circularidade" envolvida nesta problemática, que "perpassando as diferenças, as alianças e os conflitos políticos e sociais", resultava em uma "paradoxal mistura de discussão e ocultação" (2017, p. 28). Por isso conclui ressaltando a ambivalência política em questão: "Entre as repercussões completamente negativas, e as positivas, havia nuances, interligações, variações e paradoxos, gerando um modelo ao mesmo tempo delimitado e multifacetado" (2017, p. 29). Assim, ele captura a complexidade desta discussão.

\footnotetext{
"Sociedade Gregoriana", em referência ao abade francês Henri Gregóire, conhecido por sua defesa da igualdade racial e independência do Haiti durante a Revolução Francesa. Esta desavença pessoal, que tornou-se embate político público, versava sobre a existência ou não de tal sociedade secreta, que também seria integrada por nomes conhecidos como Cipriano Barata, político baiano (branco) de tendências Liberais Exaltadas. A sociedade conspiraria para promover o "assassinato dos brancos e o cruzamento das raças", segundo folheto de denúncia que circulou na Corte Imperial naquele ano (2017, p. 258-303).
} 


\section{O Haiti nas fontes primárias sem o conceito de Haitianismo}

Nas fontes primárias estudadas durante esta investigação encontrou-se uma série de mobilizações discursivas do Haiti e da Revolução Haitiana que, no entanto, não empregaram o léxico específico do Haitianismo. São menções ao Haiti esparsamente pronunciadas em discursos políticos brasileiros ao longo de todo o século XIX. Mas não ao acaso, uma vez que são encontradas em concomitância com momentos de transição política e crises sociais de vulto, como a Independência, a Regência e a proclamação da República.

Diante disto, para finalizar este capítulo, serão apresentadas breves ocasiões em que a pesquisa documental sobre discursos oitocentistas encontrou narrativas brasileiras sobre o Haiti fora do âmbito nominal do Haitianismo, dando destaque àquelas que ainda não foram divulgadas pela historiografia existente, de modo a contribuir com a ampliação de sua base empírica. No próximo capítulo, serão analisados os resultados referentes unicamente às instâncias em que o conceito de Haitianismo, ou seus derivados, foram usados textualmente.

O jornal carioca Compilador Constitucional - Político e Literário traz, em 1822 (ano da declaração de independência), um artigo sobre um enfrentamento entre tropas de terra brasileiras e uma divisão militar portuguesa, em Salvador, Bahia. O redator ensaia comparações negativas com o Haiti e faz comentários sobre a qualidade do "sangue preto", indicativo do papel de "traidores inimigos do Brasil", ainda que o argumento seja voltado contra Portugueses brancos, defensores do absolutismo, chamados de "corcundas".

De parte a parte há boas mentiras: o que piamente acreditamos, como acontece a todo imparcial, que portanto, só é Sectário de Caráter da Boa Razão, e Justiça, e da UNIÃO, TRANQUILIDADE e CONSTITUIÇÃO, que se está fazendo em Portugal, como juramos. Sem isto, iríamos cair em anarquia irremediável, que é o que querem esses Velhos tontos anglo-maníacos, e mais corcundas venais, e traidores inimigos do Brasil, e da Constituição. Meus amigos, por esse lado não pega o carro, nem o carrinho, nem o carrão: o Povo já não crê em bruxas, nem mesmo das que tem sangue preto, ou de preto, que é tão bom como o dos brancos incendiários da mesma laia, ou piores; os quais com essas lembranças, e o dizerem que os Europeus são nossos amigos à Francesa (veja-se Reverbero Revolucional [sic] Constitucional de terça-feira da Páscoa de 1822) pretendem para a felicidade do Brasil fomentar nele as horrorosas cenas da América Espanhola, e S. Domingos,

e Haiti!!! Monstros traidores... que,

Onde, sem que seu Rei tenha notícia,

Fazem o que lhe dita sua malícia. ${ }^{86}$

${ }^{86}$ Compilador Constitucional - Político e Literário, $\mathrm{n}^{\circ}$ 15, 26/04/1822, p. 4 -itálico no original, negrito adicionado. 
Por sua vez, O Cruzeiro - Jornal Político, Literário e Mercantil, de Pernambuco, publicou uma série de artigos ao longo do ano 1829 nos quais fazia menções extremamente negativas e explicitamente racistas sobre o Haiti. Trata-se de um dos periódicos mais conservadores de seu tempo. Seu redator é o vigário Francisco Ferreira Barreto, que figura como um dos melhores exemplos do tipo de “repercussão" política e discursiva da Revolução Haitiana no Brasil que articula sua análise através das chaves binárias medo/rejeição frente a um possível exemplo/inspiração. Sua luta é contra o Liberalismo, mesmo aquele que seria chamado de Moderado no país. O apelo ao medo branco de seus pares é paradigmático, concluindo com o repetido lema: não "fazer do Brasil um novo Haiti”.

Muito mais diria a este respeito, porém calo-me por agora, pois é bastante o que tenho dito para encher de vergonha e de confusão os trombeteiros da anarquia religiosa e política. Vejam pois estes senhores (não nossos) Universal, Astrea e Companhia, que estamos cercados de escravos, e temam por sua própria segurança e vida, que eles não tomem ao pé da letra tanto Cativo, tanta igualdade e desaforo com que estão continuadamente berrando de todos os cantos deste Império; lembrem-se da Ilha de S. Domingos, e não queiram fazer do Brasil um novo Haiti - Quod Deus Avertat. Amen. ${ }^{87}$

Em outra oportunidade, $O$ Cruzeiro aprofundava sua luta contra o Liberalismo, novamente invocando o medo branco e fazendo referência ao Haiti. Neste outro artigo, o autor viria a fustigar os "defensores de direitos dos homens", tidos como responsáveis pela perda de "respeito" que os setores subalternos estavam demonstrando, em sua opinião. Ele demonstra-se indignado com um suposto brinde "à saúde de um criolinho" cujo pai, um militar "pardo", teria sido celebrado como futuro presidente da província de Pernambuco, pelos presentes. Mesmo com seu racismo abertamente enunciado, o autor diz perseguir o "bem da humanidade":

Confessemos que o abuso da liberdade é um mal contagioso. Fazer o que a lei não proíbe é o círculo em que gira somente a liberdade. Dar um passo fora desta raia é cair na licença, o oposto da liberdade, a maior de todas as pestes. O homem tocado deste mal (o liberal) é semelhante ao fogoso cavalo, que desenfreado corre furioso e cegamente pisando, atropelando, quebrando, matando, e finalmente vai ele mesmo precipitar-se no abismo, a que o arrasta a cegueira e o furor. Lancemos

87 O Cruzeiro, no 40, 25/06/1829, p. 3-4. Este artigo é uma reprodução do original publicado pelo Diário Fluminense, órgão ligado ao imperador d. Pedro I, parte da imprensa áulica da época. O próprio monarca costumava escrever no periódico, sob pseudônimos, atacando a jornais da oposição. Ver: Sodré (1999, p. 111). 
espaçosas vistas sobre o teatro do mundo e vejamos quanto, e quão lamentáveis males tem causado a inculcada liberdade (ou verdadeira licença). A França ainda hoje se horroriza da lembrança dos cadafalsos, das mortes, dos assassinatos, da guerra civil. Os navegantes a passarem pelas Antilhas apontam ainda para o Haiti e dizem: "Eis ali a sepultura de tantos mil homens brancos, que foram imolados pela licença dos negros". 88

Os discursos de medo que faziam referência ao Haiti atravessaram décadas e foi possível encontrá-los também nos anos 1850. O Correio Mercantil, do Rio de Janeiro, dedicou longo artigo a comparar o "horror" do Haiti com o Brasil. O país estaria em risco diante da política repressiva ao tráfico, inclusive em terra, adotada após a entrada em vigor da Lei Eusébio de Queirós, de 1850. Intitulado "Um Grande Perigo", o artigo é uma republicação de outro periódico, A Nação. Seu autor afirma que não quer ser confundido com os defensores do tráfico e acusa os membros do atual gabinete de terem sido comerciantes de escravizados. Trata-se de uma crítica vinda do novo Partido Liberal ao governo "saquarema", isto é, conservador, naquela altura do segundo-reinado. ${ }^{89}$

Ao mesmo tempo, considera o oferecimento de alforrias para escravizados que denunciassem cativeiros clandestinos e desembarques ilegais como algo "imoral", "funesto" e "louco". Ele tenta chamar atenção dos membros do ministério, que são "Brasileiros e pais de família". Os ministros estariam “desmoralizando a [instituição da] escravatura". Ainda que "a estupidez proverbial dos negros africanos" tenha garantido segurança "até hoje", diz ele, o risco do contato entre escravizados e não escravizados, incluindo a tropa, é algo comparado a catástrofes naturais, como vulcões e tempestades. Tal narrativa é sempre intercalada com imagens e lições extraídas do Haiti.

\footnotetext{
${ }^{88}$ O Cruzeiro, $\mathrm{n}^{\circ} 35,17 / 06 / 1829$, p. 1-2. Em outra edição, o jornal prossegue no tema: "Os homens de casta no nosso território são em um numero muitas vezes superior ao dos brancos: isto é; eles têm toda a força física: entregar-lhes-emos também a pequena moral, que nos cabe em sorte, já tão enfraquecida? (...) Ora eles se expressam para igualar os brancos; mas apenas tiverem conseguido essa vantagem, a luta mudará de natureza; todos os seus esforços serão para nos dominarem, e pagar assim dependência com dependência. Lancemos hum golpe de vista sobre a Guiné Americana (o Haiti) poucas pretensões ao principio, protestos de adesão á causa do Estado, mas estes protestos se desvaneceram à proporção que a força negra se aumentava, e a desgraçada Colônia Francesa acabou por ser um Estado de negros. Poderíamos desejar outro tanto no Brasil? (O Cruzeiro, $\mathrm{n}^{\circ} 138$, 29/10/1829, p. 1-2 - negrito adicionado). Para mais informações sobre as polêmicas d'O Cruzeiro envolvendo discursivamente o Haiti, ver Morel (2017, p. 260-274).

${ }^{89}$ Segundo José Murilo de Carvalho (2014), a tática dos "saquaremas" era esvaziar a plataforma política dos Liberais mediante o cumprimento de sua agenda (como o fim do tráfico) mas sob controle político conservador, implementando as reformas que seus adversários propunham (2014, p. 224-234). Para mais sobre a política dos conservadores no segundo-reinado e construção do Estado nacional, ver a obra de Ilmar Mattos, O Tempo Saquerema (2004), assim como o trabalho de Ricardo Salles (2012), supracitado.
} 
O estudo da sanguinolenta revolução do Haiti tem despertado no Brasil as mais graves considerações no animo de todos; desde muito tempo que se reflete e se fala nisso: jamais houve época que desafiasse tanto as reflexões e os discursos sobre tal ponto. E um perigo real: convém envidar todos os esforços para removêlo: falemos pois sobre ele, mas falemos muito rapidamente, como o aconselha a prudência. No Haiti os escravos se revoltaram em 1722 , foram porém com facilidade reprimidos. No Brasil tem aparecido tentativas parciais que de pronto se há conseguido sufocar: sintomas de insurreição por mais de uma vez tem despertado a autoridade adormecida. Pouco mais ou menos como no Haiti. Em 1790 as imprudências do governo francês lançam no Haiti as sementes da revolução, que rebenta um ano depois, e transborda e arrebata diante de si tudo que encontra: duas palavras resumem toda essa revolução: 'horror!... carnificina!...' E o primeiro culpado desse horror e dessa carnificina foi o governo francês. Deus salve o Brasil de tão medonho cataclismo! [...] Nós porém estamos dormindo sobre a cratera de um vulcão: esse vulcão é a multidão dos escravos que enchem as nossas cidades e recôncavo, e por consequência, para que nosso governo não se faça merecedor das mesmas acusações que caíram sobre o governo francês em 1791, preciso é que ele, no empenho de perseguir o tráfico em terra faça proceder às necessidades diligenciais com prudência e cautela, a fim de que, para prevenir um grande mal, não caia no erro de promover um outro mal, milhares de vezes mais pernicioso. ${ }^{90}$

As comparações com o Haiti em momentos de transição política e reformas sociais alcançam o fim do Império (1822-1889). Em 1893, o jornal Correio Paraense - Diário Noticioso, Comercial e Literário, assumia sua posição monarquista em matéria de capa na qual são feitas críticas ao regime republicano recém-inaugurado. O Haiti é mobilizado como (mau) exemplo dos perigos de se proclamar a república no Brasil. O autor, Tito Franco, considera haver uma "satânica tentativa" de fazer do país um segundo Haiti com este novo regime de governo, que estaria "escravizando os brasileiros".

Não somos nós - os monarquistas - que temos medo da república que aí está escravizando o povo e afligindo os povos (...) Cresce o número de bons cidadãos desiludidos que, por todos os modos, procuram evitar co-participação nesta república haitiana.

... Diante desta ruinosa situação - qual atitude imposta pelo verdadeiro patriotismo aos monarquistas? Impedir as desolações causadas pelas águas revolucionárias que se precipitaram em borbotões de enorme volume, desde que a gente de 15 de Novembro destruíra os diques que as represavam para serem como eram inteligentemente distribuídas e cuidadosamente aproveitadas? Quem dera! Diante do impossível, sofremos as consequiências desastrosas, que não podemos ainda evitar. Elas serão debeladas quando o mal for devorado pelo fogo de suas próprias

\footnotetext{
${ }^{90}$ Correio Mercantil, $\mathrm{n}^{\text {o }} 43,12 / 02 / 1853$, p. 2 - itálico no original, negrito adicionado.
} 
entranhas. O mal é a satânica tentativa de transformar o grande Império do Brasil em uma segunda república do Haiti. ${ }^{91}$

As menções ao Haiti, fora do escopo nominal do Haitianismo, nem sempre buscaram ativar políticas de medo ou imagens negativas do país caribenho. Morel (2005; 2017) e Reis (2008) mostraram exemplos de recepções positivas dos acontecimentos revolucionários por algumas expressões da elite letrada brasileira. Existem também passagens em que as referências ao Haiti podem ser consideradas como neutras, ou próximas disto, em termos de juízo de valor. Há muitas notícias comerciais sobre entradas e saídas de carregamentos navais, assim como menções ao preço do café e do açúcar nos mercados internacionais diante de acontecimentos no Haiti. ${ }^{92}$ São narrativas descritivas dos acontecimentos no Haiti que não perseguem nenhuma agenda política específica no Brasil, até porque em muitos casos eram reproduções de reportagens de periódicos estrangeiros. Ou que reverberam os interesses de algum grupo político do país onde foram originalmente publicados, como Inglaterra ou França. São encontrados, em geral, no início do século XIX, até mesmo antes da independência, como esta matéria de 1815 da Gazeta do Rio de Janeiro (órgão oficial do governo de d. João VI):

A este artigo ajuntaremos alguns acontecimentos de S. Domingos, por terem com esta Potência [França] imediata relação.

O Rei de Haiti, Henrique, vulgarmente conhecido como Cristóvão, em um Manifesto assinado por ele, e contra-assinado pelo seu Ministro e Secretário de Estado de Negócios Estrangeiros, Conde de Limonade, declara abertos e francos os seus portos a todas as nações por via de comércio, maldiz o infame Corso, que tantas desgraças fez sofrer a sua Pátria, congratula-se com a elevação de Luiz XVIII ao trono dos Bourbons; mas longe de prestar-lhe obediência, assevera a firme resolução de sustentar a sua independência.

Em outra Proclamação, exorta os seus vassalos a alegrarem-se pelos felizes acontecimentos, que tiveram lugar na França, e na Europa toda no fim de Abril passado. ${ }^{93}$

São as mensagens de alerta e medo que, no entanto, dominaram as comparações ou menções ao Haiti no discurso político brasileiro oitocentista. Com visto ao longo deste capítulo, nos momentos de transições políticas importantes tais

\footnotetext{
${ }^{91}$ Correio Paraense, $\mathrm{n}^{\circ} 422,04 / 10 / 1893$, p. 1 - negrito adicionado.

${ }^{92}$ Esta observação já havia sido feita por Soraya de Freitas (2011), que pesquisou o Haiti nas páginas dos primeiros periódicos brasileiros, entre 1808 e 1817.

${ }^{93}$ Gazeta do Rio de Janeiro, $\mathrm{n}^{\circ} 14,1815$, p. 7 - itálico no original, negrito adicionado. No mesmo ano, o jornal voltaria a comentar sobre a política doméstica e exterior haitiana, ao reproduzir artigos de periódicos franceses interessados na "restauração da colônia de S. Domingos" (Gazeta do Rio de Janeiro $\mathrm{n}^{\circ} 33,26 / 04 / 1815$, p. 4).
} 
recursos ao Haiti tendiam a aparecer com mais frequência. Por exemplo, durante a conjuntura do processo de independência, José Bonifácio de Andrada e Silva (2011), já na condição de deputado constituinte, apresenta sua famosa Representação à assembléia geral constituinte e legislativa do Império do Brasil sobre a escravatura, na qual recomenda a transição gradual para um regime pósescravista. Sua argumentação é ao estilo dos emancipacionistas de Azevedo (2004), pois defende o fim do regime escravista a partir do apelo ao medo sentido por seus pares, homens brancos e proprietários, "de uma revolução como a de São Domingos" (ANDRADA E SILVA, 2011, p. 181).

\begin{abstract}
Vós sabeis, senhores, que não pode haver indústria segura e verdadeira, nem agricultura florescente e grande com braços de escravos viciosos e boçais. Mostra a experiência e a razão que a riqueza só reina onde impera a liberdade e a justiça, e não onde mora o cativeiro e a corrupção. Se o mal está feito, não o aumentemos, senhores, multiplicando cada vez mais o número de nossos inimigos domésticos, desses vis escravos, que nada têm que perder, antes tudo que esperar de alguma revolução como a de São Domingos. Ouvi pois, torno a dizer, os gemidos da cara pátria, que implora socorro e patrocínio: pelejemos denodadamente a favor da razão e humanidade, e a favor de nossos próprios interesses. (2011, p. 181-182)
\end{abstract}

Um ano antes, o próprio d. Pedro, no Manifesto de 6 de agosto de 1822, acusava seus inimigos nas Cortes de Lisboa de começarem uma "guerra civil" no Brasil, no intuito de reviver as "horrorosas cenas de Haiti". Este manifesto faz parte da coleção Leis do Império. Como se vê, até nos mais altos escalões da nascente elite política brasileira fazia-se discursos referenciados no Haiti, para distintos fins. Grosso modo, a condição de antiexemplo preferencial daquilo que o Brasil deveria ser era mantida, segundo os enunciadores. O recurso ao Haiti é feito para mostrar o grau de torpeza do inimigo político de quem o menciona.

À vista de tudo isto, já não é mais possível que o Brasil lance um véu de eterno esquecimento sobre tantos insultos e atrocidades; nem é igualmente possível que ele possa jamais ter confiança nas Cortes de Lisboa, vendo-se a cada passo ludibriado, já dilacerado por uma guerra civil começada por essa iníqua gente, e até ameaçando com as cenas horrorosas de Haiti, que nossos furiosos inimigos muito desejam reviver. ${ }^{94}$

\footnotetext{
${ }^{94}$ Brasil - Coleção Leis do Império - 06/08/1822, p. 132, vol. 1 - negrito adicionado.
} 


\section{Considerações finais}

Após recorrer esta plural amostragem bibliográfica é possível notar que o Haitianismo é um conceito instável semanticamente, sendo reclamado por diversas interpretações nem sempre congruentes umas com as outras. Cada autor ou escola de pensamento que olha para o Haitianismo parece ter algo próprio a falar, dentro de seus debates particulares. De modo geral, mas nem sempre, é subsumido ao tema das repercussões da Revolução Haitiana no Brasil, até por autores que identificam sua especificidade discursiva, como Morel (2017).

O Haiti e o Haitianismo, assim, são mencionados para ilustrar argumentos que vão desde a forte presença e agência política de seres humanos racializados como negros e escravizados no Brasil imperial (por exemplo, nos debates sobre a escravidão, tráfico e abolição, de modo a contrapor a tendência de conferir protagonismo ou mesmo exclusiva agência ao movimento abolicionista branco), ${ }^{95}$ até proposições sobre as especificidades do processo de independência brasileira ${ }^{96}$ e de formação do Estado e da identidade nacional do país. ${ }^{97}$ Muitos o abordam como forma de ilustrar o racismo da nascente elite política e intelectual imperial, destacando sua presença nas formulações de medo branco. ${ }^{98}$ Contudo, também há quem discuta o tema buscando mostrar as alusões simpáticas ao Haiti revolucionário, incluindo entre os setores não escravizados ou proferidas por pessoas consideradas como brancas. ${ }^{99}$ Com efeito, ao fim, o Haiti e o Haitianismo são mencionados tanto como dispositivos facilitadores de agendas políticas conservadoras, centristas ou radicais, a depender do autor que o aborde e das agendas de pesquisa que o mobilizam discursivamente.

Estudos mais detidos percebem seu uso como insulto político ou campanhas de medo para fins eleitorais, ministeriais ou de perseguição ideológica, na forma de provocações e rumores racistas circulados pela imprensa e outros meios. ${ }^{100}$ Há quem o invoque para descrever aspectos posteriores e mesmo atuais da sociedade

\footnotetext{
95 Araújo et al. (2006); Bezerra Neto (2001); Ferreira e Gomes (2008); Gomes (2002); Gomes e Soares (2002); Moura (1959); Mott (1988); Reis (1995; 2000; 2014).

${ }^{96}$ Carvalho (2014); Freitas (1978); Mello Mourão (2009).

${ }^{97}$ Schwarcz e Sterling (2015); Flory (1977); Nascimento (2008).

98 Azevedo (2004); Batista (2014); Prado Jr. (1979).

${ }^{99}$ Morel (2005; 2017); Silva (2016).

100 Andrade (2012); Borba de Sá (2016); Flory (1977); Morel (2017).
} 
brasileira, como feito por geógrafos ${ }^{101}$ sociólogos ${ }^{102}$ e criminologistas críticos. ${ }^{103}$ Reiteradas vezes aplica-se a fórmula binária medo/inspiração, ou exemplo/repúdio, existindo até mesmo uma vertente que tenta questionar a própria relevância ou existência daquilo que é descrito como Haitianismo, na expectativa de diluir os efeitos do racismo na formação social brasileira, como, por exemplo, os discursos sobre democracia racial ${ }^{104}$ e os de uma suposta ausência de raça no debate político imperial, mesmo em meio à escravidão. ${ }^{105}$

Uma distinção crucial para compreender esta problemática é justamente aquela que identifica a separação entre, por um lado, os usos do Haiti e do Haitianismo no debate político brasileiro oitocentista e, por outro, os usos que sucessivas gerações de historiadores e outros analistas lhes deram. Frequentemente ambos foram tratados como se constituíssem um só objeto, quando na verdade são múltiplos, tanto entre seus verbalizadores no século XIX, quanto entre as diferentes abordagens historiográficas dos séculos XX e XXI. Algumas incongruências cronológicas e também espaciais lançam suspeitas quanto a utilização extensiva do conceito de Haitianismo. Não há registro de tal conceito haver figurado no léxico político cotidiano, ou na historiografia, de outras sociedades escravistas que também sofreram impactos e repercussões da Revolução Haitiana. É um produto do Brasil.

Trata-se de um conceito cuja trajetória meteórica no discurso político brasileiro é notável. As tão revisitadas "repercussões" da Revolução Haitiana de fato existiram desde fins do século XVIII nas narrativas políticas brasileiras e prosseguiram depois, mas o conceito de Haitianismo tem seu uso restrito ao curto período entre 1831 e 1836, quando praticamente todas as forças políticas mobilizaram-no com assiduidade e afinco. Sabendo que a Revolução no Haiti terminou em 1804, o que explicaria esse recorte temporal já distante no tempo frente ao objeto que supostamente repercute? E se as "repercussões" da Revolução Haitiana deram-se mundo afora, com destaque para as sociedades escravistas atlânticas (BLACKBURN, 2006; GEGGUS, 1989; GENOVESE, 1979; GÓMEZ,

\footnotetext{
${ }^{101}$ Porto-Gonçalves (2006).

102 Cardoso (2008); Silva (2016).

${ }^{103}$ Batista (2014).

${ }^{104}$ Freyre (2004).

105 Berbel e Marquese (2007); Marquese (2004; 2006); Nishikawa (2005).
} 
2006), por que somente no Brasil foi criado um neologismo próprio para expressar processos supostamente comuns?

Estar-se-ia perdendo algo de relevante que um olhar mais detido às enunciações do conceito pudesse sugerir? Como observado neste capítulo, somente a historiografia brasilianista norte-americana interessou-se, por exemplo, por interrogar o desuso do Haitianismo, suas causas e possíveis implicações para a vida política do Império. A maioria dos historiadores brasileiros, curiosamente, dá mais atenção à outras indagações e não oferece nenhuma hipótese sobre este ponto, uma vez que para eles o Haitianismo, de fato, nunca acabou: tais historiadores mantiveram-lhe vivo, transformando-o semanticamente até na forma de catacreses, para atender às suas respectivas agendas de pesquisa, ao passo que não observaram o fim de sua existência empírica na documentação primária da era imperial até muito recentemente. E também expandiram sua existência para espaços onde jamais fez parte do léxico político, ainda que não faltassem alusões e repercussões da Revolução Haitiana, as vezes sentida de forma até mais dramática do que no Brasil, como nas sociedades escravistas de Cuba e Jamaica, vizinhas à ilha revolucionária, conforme mostram os conhecidos trabalhos de Ada Ferrer (2012) e David Geggus (1981), respectivamente.

O próximo capítulo, que observa detalhadamente as fontes primárias em que mobilizações textuais do Haitianismo são encontradas, oferece um modo mais nítido de ver as marcas da colonialidade e do biopoder que permeavam este regime discursivo particular. Os múltiplos sentidos e usos vistos na historiografia foram tornados confusos pela amalgamação habitual, porém imprecisa, dentro do conceito de Haitianismo, para designar todo tipo de repercussão da Revolução Haitiana no Brasil quando, na verdade, a palavra tem uma história em si, mais curta e semanticamente mais precisa, ainda que flexível, do que as repetidas alusões ao seu nome tendem a sugerir. A história do Haitianismo e dos impactos da Revolução Haitiana no Brasil, portanto, não são exatamente a mesma coisa, como veremos a seguir, mesmo que o discurso de controle e vigilância estatal sobre populações racializadas como negras e perigosas, no entanto, lhes seja comum. 


\section{CAPÍTULO 4: Haitianismo: biopoder e colonialidade na produção do Brasil}

Para facilitar a apresentação de um considerável escopo de material empírico, este capítulo irá propor sua visualização a partir do que se identificou como seis modalidades de uso do conceito de Haitianismo nas fontes primárias do Brasil imperial. Tais modalidades foram definidas com base nos objetivos políticos de cada enunciação, assim como nas funções que poderia desempenhar nos embates e jogos de linguagem em que operava. São classificações artificiais, a título ilustrativo, de uma pluralidade de usos que, na realidade, se misturavam e eram empregados simultaneamente nas vozes de seus enunciadores: homens do mundo político e intelectual branco brasileiro dos anos 1830 .

Como será possível perceber, o Haitianismo estava e, ao mesmo tempo, não estava ligado à temática da Revolução Haitiana e sua possível repetição no Brasil imperial. Ainda que a referência ao Haiti seja inevitável diante da cunhagem de um tal significante, seu emprego esteve mais fortemente ligado à topografia discursiva das agendas políticas locais, especialmente no Rio de Janeiro, sede do Império. Ao rastrear-se as aparições do Haitianismo na imprensa política do Período Regencial, pode-se captar os efeitos de poder que produziu, do conturbado ano de $1831 \mathrm{em}$ diante. Isto significa compreender o que este conceito era capaz de fazer nos embates políticos em que era evocado, revelando, assim, a colonialidade e o biopoder envolvidos em tais lutas. É ver o Haitianismo em ação.

Ideias como raça e pátria, ordem, justiça e poder, permeadas pela discussão da escravidão e do tráfico de escravizados, estão amplamente presentes nas práticas discursivas dos acalorados debates onde o Haitianismo foi de fato empregado. Há também intrigas pessoais e eleitorais, que frequentemente dominavam o espaço discursivo deste complexo conceito, ao mesmo tempo polissêmico e com referências políticas e raciais autoevidentes. Seu uso varia, mas não ao acaso, como será visto. $\mathrm{O}$ enredo geral sempre contém motivos raciais, conspirativos, na forma de denúncias contra a conduta antiética (impolítica, se dizia na época) e arriscada dos adversários.

Além das disputas cotidianas, há temas de fundo que são de grande vulto neste momento particular de produção discursiva do Brasil pós-colonial. A unidade 
territorial, a forma e o regime de governo estavam em discussão entre as elites políticas e intelectuais. O debate era público e o embate violento. ${ }^{106}$ Era um momento de revoltas provinciais contra a sede de poder estatal no Rio de Janeiro e também contra as forças políticas que predominavam na Corte e províncias adjacentes. Revoltas como a Cabanagem, no norte do país, ameaçavam ainda mais por seu caráter popular, em que os setores não brancos e subalternizados, classificados como "indígenas" e "negros", ensejaram alusões à Revolução do Haiti. ${ }^{107} \mathrm{O}$ léxico do Haitianismo fez parte deste contexto, permeando as manchetes e pautas de veículos como a Aurora Fluminense, periódico de maior influência em seu tempo. ${ }^{108}$ Entretanto, em vez de somente advertir contra a repetição de um novo Haiti, o conceito foi ganhando vida própria, geralmente ligado à finalidades políticas imediatas, locais, pessoais.

No mesmo ano em que este vocábulo passa a ser usado, em 1831, também havia sido derrubado um imperador e estabelecida uma instável Regência Provisória devido à cisão dos grupos que se uniram temporariamente contra o regime de Pedro I, levando a perseguições, atentados, expurgos militares, denúncias de conspirações e golpes de Estado. Rumores de sublevações de regimentos militares e de instrumentalização política de escravizados foram frequentes. No segundo semestre, a atmosfera seguiu carregada, com episódios como a rebelião militar de 14 de julho e o Massacre do Teatro, em 28 de setembro, quando Liberais Exaltados foram executados por forças paramilitares de uma facção política rival, tudo em meio à discussão da primeira das leis contra o tráfico escravista, promulgada em novembro. ${ }^{109}$

\footnotetext{
${ }^{106}$ Segundo um estudioso deste período: “A política não se limitava a debates ideológicos e votações no Parlamento e editoriais de jornais, ou a rebeliões armadas alternadas com discussões e negociações. A política envolvia o exercício do poder, e para manter o poder nas mãos da minoria era fundamental defendê-lo das ameaças que vinham da maioria, fossem elas políticas ou sociais" (HOLLOWAY, 1997, p. 107).

107 Além dos periódicos vistos a seguir neste capítulo, a obra de Décio Freitas, A Miserável Revolução das Classes Infames (2005), contém fontes inéditas sobre a Cabanagem e também faz esta comparação com o Haiti (2005, p. 217-220).

${ }^{108}$ Para uma caracterização ampla da relação entre imprensa e política no Brasil no imediato pósindependência e durante o Período Regencial, ver História da Imprensa no Brasil, de Nelson Werneck Sodré (1999, p. 98-128). Ver também Andrade (2012), que discute o Haitianismo em sua apreciação da imprensa Liberal Moderada do mesmo período. Para uma discussão sobre a relação entre retórica e política, sob o prisma da "história intelectual", que trata de periódicos que mobilizaram intensamente o universo discursivo do Haitianismo, ver Carvalho (2000, p. 145-147). ${ }^{109}$ José Murilo de Carvalho (2014) faz um paralelo entre os embates em torno desta legislação, conhecida como "lei para inglês ver" na historiografia brasileira, e o Haitianismo (2014, p. 294295). Sobre os conflitos sociais no Rio de Janeiro sob a ótica da construção das forças policiais e de
} 
Utilizado com intensidade pelas três grandes forças do universo político branco da Era Regencial (Liberais Exaltados, Liberais Moderados e Restauradores), o Haitianismo parecia conferir ao seu enunciador um grande poder de atrair a atenção dos pares ou de adversários de quem empregava este conceito ou suas variantes. ${ }^{110}$ Envolvia uma acusação gravíssima, uma ofensa para qualquer uma das três forças políticas principais. Pois o apelo semântico e emocional do Haitianismo era justamente o de fazer recordar uma situação considerada além do limite tolerável das práticas políticas e da moralidade pública, já que o temor sociorracial (branco e proprietário) era comum às todas as forças, que não aceitavam, portanto, serem identificadas com traições à pátria na forma de incitamento de escravizados para fins políticos egoístas e imediatos. Tanto os mais radicais quanto até mesmo (os poucos) políticos autoconsiderados como não brancos ("pardos" ou "mulatos") demonstravam indignação caso fossem acusados de Haitianismo.

As fontes pesquisadas referem-se na sua maioria à jornais de época e também a discursos pronunciados nas casas legislativas imperiais. É exagero afirmar que "[a] vida política quase se resumia na imprensa" (Sodré, 1999, p. 111), mas é inegável que imprensa política se confundia com a própria classe política nesta época, que travava sua "guerra política" através de uma "guerra de retóricas" (CARVALHO, 2000, p. 146). O objetivo deste olhar sobre o acervo documental disponível é investigar mais detidamente expressões da colonialidade e mecanismos de biopoder em que o Haitianismo estava envolvido, de modo a permitir seu cruzamento analítico com as práticas discursivas em torno da MINUSTAH, analisada no capítulo 5.

\section{Suspensão ou redução de direitos}

Em uma sociedade escravista e patriarcal, como o Império Brasileiro, a suspensão ou redução de direitos civis e políticos só podia acontecer para quem já os tinha, ou seja, homens brancos, ou não negros, com renda suficiente para

\footnotetext{
segurança na cidade durante o Período Regencial, com destaque para o conturbado ano de 1831, ver Holloway (1997, p. 82-86).

${ }^{110}$ Essa nomenclatura das forças políticas é traduzida por um estudioso da imprensa política da época como esquerda liberal; direita liberal e direita conservadora, respectivamente: "Pouco a pouco, no tempo, mas acentuadamente, quanto às posições, a imprensa definiria o quadro de agitações que culminaria em 1831. A partir de 1827, aprofundando-se ano a ano, os periódicos dividem-se, quanto à orientação, refletindo a realidade. Como as forças políticas cindem-se, caracterizando as três componentes principais - direita conservadora, direita liberal e esquerda liberal - a imprensa acompanha a cisão" (SODRÉ, 1999, p. 110).
} 
participar do sistema eleitoral e da vida política de modo ativo. Neste espaço político e jurídico privilegiado, o Haitianismo foi um instrumento usado textualmente para justificar agendas políticas que visavam a redução de direitos, como observado pela capa do Pão D'Assucar - Jornal Político e Literário de 7 de abril de 1835, mencionada por Malaguti Batista (2014, p. 190). O redator denunciava que a propagação do medo do Haitianismo atendia a finalidades cerceadoras de direitos constitucionais pelo grupo político predominante na Assembleia Provincial do Rio de Janeiro e na Regência naquele instante, o Partido Liberal Moderado.

Foram suspensas as garantias pela Assembleia Provincial do Rio de Janeiro em virtude da existência do Haitianismo, que, segundo a Mensagem da mesma Assembleia, consta a todos, (menos a nós!) e que as doutrinas haitianas são aqui apregoadas com impunidade; que há na Corte Sociedades secretas neste sentido; e que tem cofres para os quais contribui grande número de sócios de cor, livres e cativos; e que os membros dessas sociedades nacionais e estrangeiros são indigitados pela voz pública \&c. Não sabemos por que nova política se pretende hoje manter em harmonia a grande família Brasileira! Consta a todos, e as autoridades dormem a este respeito! Consta a todos, e ninguém, apesar do perigo, se apresenta mostrando de que modo lhe tem constado que existem tais Sociedades, que possuem cofres \&c. Sabem-no os Deputados de uma Assembleia, e nem um só destes por um meio qualquer secreto comunica ao Governo a existência da coisa, que, segundo o nosso pensar, devera ser sempre em segredo, a fim de surpreender tal Sociedade! Se pois ninguém tem comunicado coisa alguma ao Governo, como vemos da resposta à Mensagem, apesar do - consta a todos - parece que justo fora, que a Assembleia Provincial em sua sabedoria, tendo ciência do objeto, e depois da Sessão secreta, o comunicasse secretamente ao Governo; o que neste caso nos parecia mais político nas circunstâncias atuais. É sem dúvida repreensível a indolência da Polícia da Corte, quando constando a todos, e com tantas particularidades, a existência das Sociedades haitianas, ela tudo ignore.

Nada cremos mais pernicioso, que a propalação dessas ideias de haitianismo; e até é para nós bem pasmosa a publicidade que se lhes tem dado, chegando-se a ponto de dizer-se, que existem semelhantes Sociedades secretas, quando melhor convinha, admitida a existência, prevenir-se ao Governo, e em silêncio, daquilo que se soubesse, visto que constando a todos, de uma ou de outra parte se achariam traços que encaminhassem ao conhecimento da realidade; e destarte cientificando o Governo acerca do objeto, ele surpreenderia tais Sociedades em suas reuniões. Mas não se havendo praticado assim, antes dando-se com semelhante publicidade sinal vivo à estas Sociedades para que se acastelassem, frustrou ao Governo os meios de surpreender facilmente os haitianos. Tanto esta publicidade nos parece má, que não só fez prevenir as Sociedades secretas, como mesmo, no caso de não existirem, despertou uma ideia até então não sugerida. Tantas medidas de cautela, tomadas como que a toque de sino; suspensões de garantias, e \&c. dão a perceber muito receio! Não julgamos isto bom: quiséramos medidas de prevenção: quiséramos vigilância a respeito; mas não tanta bulha. ${ }^{111}$

${ }^{111}$ A grafia de época foi atualizada pelo autor desta tese para os padrões atuais de modo a facilitar a compreensão dos argumentos. Os originais podem ser encontrados na Hemeroteca Digital ou microfilmados pela Biblioteca Nacional brasileira. Os nomes dos jornais consultados serão referidos 
Vale notar que este jornal é inequivocamente conservador, ligado aos interesses mercantis mais prósperos da Corte imperial, majoritariamente controlado por portugueses. No período compreendido entre a Abdicação de d. Pedro I em 1831 e sua morte em 1834, este grupo foi acusado de tentar a Restauração do regime do monarca e a subsequente reaproximação política com a ex-metrópole. Desta forma, é salutar que mesmo tal setor, poderoso e próspero, temia os efeitos de poder do Haitianismo, como a suspensão das garantias constitucionais numa atmosfera de perseguição política e pessoal ativa.

A referida Mensagem ao Trono, enviada pela Assembleia Provincial ao Governo Central em 17 de Março de 1835, que provocou tamanha desconfiança no editor do Pão de D'Assucar, fora publicada na íntegra pelo Aurora Fluminense, dias antes. Fala-se, de fato, de "doutrinas haitianas" em meio a uma dramática exposição de perigos de caráter sociorracial representado pelo "espírito de insurreição de alguns escravos" na capital do Império, que sofreria o efeito da Revolta dos Malês na Bahia, dois meses antes. A importância política desta retórica é, assim, possível de ser dimensionada, assim como seu poder de instigar os mecanismos de vigilância estatal, especialmente sobre corpos racializados como negros no Brasil pós-colonial. A suposta sociedade secreta era composta por "sócios de cor, livres e cativos", segundo a Mensagem enviada ao poder executivo:

\begin{abstract}
A Assembleia Legislativa do Rio de Janeiro não pode um só momento demorar-se em levar ao Trono de V.M.I. por esta sua respeitosa mensagem, os cuidados e os receios que súbita a tomaram e ocupam, de que a paz e a tranquilidade em que existia a Província, e em cujo remanso se propiciaram e prosseguiram seus trabalhos legislativos, venha ser interrompida e perturbada pelos últimos acontecimentos da Bahia, onde uma insurreição de escravos parece ameaçar não só a total ruína dessa bela porção do Império, mas de todas as outras Províncias, entre as quais não pode a do Rio de Janeiro deixar de ser a primeira em sentir o efeito de tão funesta causa, já pela proximidade do território, já pelo número desproporcional de escravos que emprega em sua opulenta e extensa lavoura, e já pela impolítica mistura de Africanos livres que entre nós se conservam. Estes receios, Senhor, não são infundados. A todos consta que as Doutrinas Haitianas são aqui pregadas com impunidade; que os escravos são aliciados com o engodo da liberdade, e concitados por espíritos vertiginosos, nacionais e estrangeiros, dentro e fora da Província, para romper nas mesmas comoções, de que estão os da Bahia dando funestíssimo exemplo: que há na Corte Sociedades secretas que trabalham sistematicamente neste sentido; que têm cofres para os quais contribui
\end{abstract}

no corpo do texto e as citações diretas serão referenciadas em notas de rodapé com as iniciais do periódico, o número ou volume, a data de publicação e a página de onde foi extraída. Neste caso: PA, $n^{\circ} 27,07 / 04 / 1835$, p. 1 - negrito adicionado. 
grande número de sócios de cor, livres e cativos; que destes cofres saem os subsídios com que se entretém e mantém Emissários, encarregados de propagar doutrinas subversivas pelos escravos das fazendas de lavoura, onde se introduzem a título de mascates ou pombeiros! Os membros dessas Sociedades, e seus fautores nacionais e estrangeiros, são indigitados pela voz pública... e todavia parece que a Administração policial da Corte ou tudo ignora, ou estranhamente, descuidada dorme sobre a cratera do vulcão! E entretanto o incêndio já lavra perto da porta! ${ }^{112}$

Segundo o Pão D'Assucar, tanto a mensagem quanto o decreto de suspensão de garantias constitucionais foram elaborados em uma "Comissão da Assembleia Provincial acerca do Haitianismo", ou "Comissão do Parecer sobre o Haitianismo". Ainda preocupado com a redução das liberdades civis e políticas, o redator deste jornal comemora o fato do ministro da Justiça, Alves Branco, ter desconsiderado a Mensagem da Assembleia Provincial, enfraquecendo a campanha de medo e também as eventuais ameaças insurrecionais:

Louvores sejam dados à Regência pela escolha dos atuais Ministros; e graças ao impávido Alves Branco, que com dois traços de pena nos preservou de males, que pouco sabemos calcular! Este digno Ministro, senhor da posição que ocupava, longe de dar vulto ao fantasma haitiano, que se erguia lá da Vila de Campos, ele esmaga a pés o pomo da discórdia, e toma medidas de cautela como convinha, sem dar a publicidade que deu o Presidente da Província em sua Mensagem (método novo de surpreender criminosos, e criminosos tais!); e por este modo desaparece o Haitianismo (...) Nós não somos Ministeriais, e conquanto nos achemos nas fileiras da Oposição, mesmo assim não podemos recusar os louvores que cabem aos nobres Ministros de 1835. Pensem bem os brasileiros nas consequências que se poderiam seguir d'esse Parecer da Comissão d'Assembleia Provincial acerca do Haitianismo, tendo além disso o consta a todos da Mensagem, e Suspensão de Garantias Constitucionais, que não diziam respeito à africanos, porque estes não são Cidadãos Brasileiros, se o $\operatorname{Exm}^{\circ}$ Alves Branco houvesse tido outra conduta sobre o objeto em questão! Progrida assim o Governo, coloque-se entre os Partidos, não tendo atenções a este ou aquele, na administração da justiça, que o Brasil pode ainda ser feliz; e a Nação que jamais foi ingrata, reconhecerá seus bons serviços. ${ }^{113}$

O decreto elaborado pela Comissão da Assembleia Provincial sobre Haitianismo foi levado à plenário e aprovado após três votações. Nele não há menção textual ao Haitianismo ou conceitos derivados, ainda que na Mensagem ao Trono sim. São oito artigos que suspendem ou reduzem os direitos assegurados pela constituição imperial, mediante uma demarcação explicitamente baseada em critérios raciais e políticos a fim de legalizar ações de exceção estatais contra ameaças consideradas subversivas. A criminalização da atividade política, sob tais critérios, é aprovada em 17 de março de 1835.

${ }^{112} \mathrm{AF}, \mathrm{n}^{\mathrm{o}} 1032,27 / 03 / 1835$, p. 2 - negrito adicionado.

${ }^{113} \mathrm{PA}, \mathrm{n}^{\circ} 32,28 / 04 / 1835$, pp. 2-3 - itálico no original, negrito adicionado. 
Art.1. Ficam suspensas em toda a Província do Rio de Janeiro até a primeira reunião ordinária ou extraordinária da Assembleia Legislativa Provincial, as formalidades do artigo 179, $\S \S 7,8$ e 9 da Constituição do Império, a fim de proceder-se sem as garantias dos seguintes parágrafos, contra todos os indivíduos sobre quem recaírem indícios veementes de que tentam perpetrar o crime de insurreição, e por este crime somente. Os que escreverem, e os que publicarem proclamações e quaisquer outros papéis, assim impressos como manuscritos, ou proferirem discursos diretamente tendentes a promover insurreição, serão punidos como cúmplices desde crime (...).

Art. 5. Fica proibido às Sociedades secretas, permitidas pelo art. 282 do Código Criminal, celebrar de noite as suas reuniões, sob pena de serem consideradas criminosas, e de se proceder contra elas nos termos do artigo citado, e do 284, ainda que tenham feito comunicação de forma legal ao Juiz de Paz respectivo.

Art. 6. Todas as associações secretas, onde for encontrado algum estrangeiro de cor, entrando nessa classe os Africanos libertos, e os que forem escravos, ficam declaradas criminosas: e todos os indivíduos que nelas forem apreendidos, serão reputados como achados em ato de tentativa de insurreição, ainda que a reunião se verifique de dia, e não exista outra alguma prova, que o simples fato da reunião em forma de associação, provada pelo auto legal do corpo de delito de apreensão. ${ }^{114}$

Esta polêmica sobre restrição de direitos foi retomada no mês seguinte pela imprensa política da capital imperial. Novamente o Pão D’Assucar abre seu editorial de capa, em maio de 1835, debatendo contra os jornais ligados ao Partido Liberal Moderado, no poder regencial e provincial naquele momento, a quem acusa de inventar termos pejorativos para "toda a oposição". Segundo esta percepção, o Haitianismo teria servido para difamar os Liberais Exaltados, ao passo que o neologismo Retrogredação identificaria pejorativamente aos antigos Restauradores (do reinado de d. Pedro I, morto um ano antes) e demais forças conservadoras. Mas este segundo termo teve vida mais curta, possivelmente indicando que o temor provocado pela ideia de recolonização europeia era menor, ou menos instigante de usos, do que aquele que cruzava os limites raciais da vida política e econômica. ${ }^{115}$ Mais adiante, o mesmo editorial rebate furiosamente a acusação de "retrógrado" e, ao fazê-lo, o redator fornece uma lista de ações de exceção e arbitrariedade estatais que estariam sendo tomadas pelos Moderados contra seus adversários políticos, em especial a suspensão do direito de Habeas Corpus. Ela ajuda a perceber o clima de tensão política e de exercício violento do poder de vigilância sobre membros das oposições e resistências em curso. Interessante notar que mesmo um autor conservador mostrava preocupação com os abusos sofridos

\footnotetext{
${ }^{114} \mathrm{O}$ decreto foi publicado na íntegra pelo Aurora Fluminense, $\mathrm{n}^{\mathrm{o}} 1.032,27 / 03 / 1835, \mathrm{p} .2$.

${ }^{115}$ Lê-se no jornal: "Não podendo mais valer a favorita da Restauração, fora necessário que se inventasse um outro motivo de cantiga: isto se fez; e surgiu o Haitianismo: mas não podendo este bem aproveitar, por não ser possível que toda a oposição fosse haitiana, recorreu-se à retrogredação; com a qual somos hoje apelidados pela Santa Moderação!’. PA, n 35, 08/10/1835, p. 1.
} 
também pelos Exaltados, adversários de seus adversários, naquele instante. $\mathrm{O}$ trecho refere-se ao duo discursivo Haitianismo e Retrogredação e, novamente, mostra sua ligação com práticas de redução de direitos e normalização das ações de exceção por parte do poder estatal.

Só pode ser retrógrado quem manda apedrejar sociedades permitidas por lei; arrombar casas a machado; despedaçar Tipografias, e esfaquear o Cidadão pacífico à porta de sua loja. Só pode ser retrógrado aquele Ministério, que manda sair para fora do Império a indivíduos presos pelo crime de conspiração, e depois tentativa, que se achavam entregues às Justiças, e que ainda não haviam sido sentenciados. Só pode ser retrógrado quem nega execução a mais santa das garantias sociais, o Habeas Corpus (...) retrógrado é aquele que assassina judicialmente o desgraçado, e que por cúmulo de perversidade, afirma haverem-se guardado todos os quesitos da Lei, quando lhe tem negado todos os recursos. ${ }^{116}$

Um exemplo notório dessa redução de direitos era a perseguição sofrida pelo veterano político (branco) Cipriano Barata, um dos ícones do Liberalismo Exaltado da época. Conforme já debatido por Morel (2017, p. 275-303), as arbitrariedades cometidas contra Barata foram envoltas nas mesmas acusações de Haitianismo que recaíram sobre alguns personagens políticos do Império, que pouca ligação tinham entre si. Mesmo assim, foram acusados de pertencerem a uma Sociedade Gregoriana ou Sociedade Haitiana, que conspiraria contra a ordem sociorracial escravista e proprietária no Brasil. ${ }^{117} \mathrm{O}$ jornal fundado por Barata, a Sentinela da Liberdade, em sua versão no Rio de Janeiro, para onde foi levado encarcerado, denunciava o uso do Haitianismo como estratégia de perseguição política e ideológica contra radicais, principalmente por parte da Aurora Fluminense, órgão de ponta dos Liberais Moderados.

Não tardará muito que a Branca Aurora ou seus companheiros, especialmente o Independente nos mimoseie com epítetos de fusco mal vestido, haitiano, cruzador, assim como esse papelão apelidou ao valente mártir da Pátria, o respeitável ancião BARATA! ${ }^{118}$

Não venha a Aurora meter medo ao Sentinela com haitianismos, e outras farsas, como estas, que esse tutu já não assusta por mau uso que dele fizeram. ${ }^{119}$

\footnotetext{
${ }^{116}$ PA, no $35,08 / 05 / 1835$, p. 1.

117 Morel $(2005 ; 2017)$ pesquisou detidamente a influência do abade francês Henri Grégoire no Brasil e as polêmicas envolvendo supostas sociedades geregorianas e possíveis seguidores de duas ideias no Brasil imperial. O Haitianismo está no cerne de tais discussões.

${ }^{118}$ SLRJ, $\mathrm{n}^{\circ} 06,12 / 12 / 1832$, p. 2 - itálico no original, negrito adicionado.

${ }^{119}$ SLRJ, no $13,17 / 01 / 1833$, p. 1 - negrito adicionado.
} 
A imprensa política do Partido Exaltado (ou Partido Nacional, como também se autoidentificavam) rebatia em peso tais acusações contra seus líderes políticos e representantes intelectuais. Por exemplo, o título da matéria de setembro de 1831 na capa do periódico O Jurujuba dos Farroupilhas é "MAIS HAITIANISMO”, em caixa alta. No texto, afirma-se que:

É do haitianismo em 31 que ainda vai tratar o Jurujuba, posto que os servos do Governo só querem que se diga serem os Snrs. Barata, Ezequiel, e a Nova Luz os únicos autores do velho-novo Haitianismo de 31. Já serviu-nos o bom folheto do Sr. Silva para irmos descobrindo os pérfidos haitianos de hoje...

... do Ministério de d. Pedro haviam partido ordens na Fragata Izabel (enviada pelo Sr. Paranaguá, amigo do Sr. Lino) para a prisão do Sr. Barata, as quais ordens a Regência Provisória conservou inadvertidamente; pois dá vistos de conveniência, e aprovação destes despotismos militares, e armadilhas tão disparatadas, só próprias do ex-imperador (e de quem lhe segue a pérfida política). ${ }^{120}$

$\mathrm{Na}$ voz deste locutor, o Haitianismo era um dispositivo discursivo construído para fazer crer que os Liberais Exaltados eram mais radicais ("anarquistas") do que de fato eram, com isto autorizando e legitimando sua perseguição política e pessoal, inclusive preventivamente. Após uma participação decisiva nas mobilizações populares e militares que exigiram a caída do imperador entre Março e Abril, houve receio quanto à influência das doutrinas Exaltadas entre os soldados de algumas unidades, gerando discussões sobre a dissolução destes corpos. Neste contexto, houve quem os responsabilizasse por uma tentativa fracassada de agitação das forças do Arsenal da Marinha do Rio de Janeiro no dia 14 de julho 1831, ou seja, justo no dia da Queda da Bastilha na Revolução Francesa, quando presos políticos foram libertados pelas massas revolucionárias em Paris. O Haitianismo, neste exemplo, mostra-se também em sua forma verbal ("haitianar") na resposta dos Liberais Exaltados.

(...) são os fuscos ambiciosos que lançam esse labéu sobre Barata, Queiroz, Ezequiel e Nova Luz que fazem brecha nos haitianos, quando pedem reformas à bem dos Pretos. O governo entende já que por aqui ninguém acredita que tenha Queiroz influência para haitianar tudo, e fazer, ainda mais, o 14 de Julho? O Povo se ri de tudo, e suspeita que... Oh leré... Reflita nisto o Sr. Governo; e digam ao Jurujuba dos farroupilhas se ainda acreditam no haitianismo, e anarquia, e 14 de Julho do Queiroz? ${ }^{121}$

${ }^{120} \mathrm{JF}, \mathrm{n}^{\circ} 5,23 / 09 / 1831$, p. 1-2 - itálico no original, negrito adicionado.

${ }^{121} \mathrm{JF}, \mathrm{n}^{\circ} 5,23 / 09 / 1831$, p. 3 - itálico no original, negrito adicionado. 
Outra influente folha Liberal Exaltada, a Nova Luz Brasileira, também trazia exemplos de arbitrariedades, redução ou cerceamento de direitos. Neste caso, um tribunal de exceção e paralelo ao Estado teria decido sobre a vida e a morte de opositores ao regime. A linguagem da Nova Luz por vezes confundia-se com aquela dos próprios rumores que corriam na época envolvendo o Haitianismo. ${ }^{122}$ Nota-se a associação entre ser "haitiana" e merecer pena de morte, naquele momento. Um automatismo que decide sobre vida e morte. E não é questionado pelo autor, que até mesmo o reforça, ainda que seja vítima de tal dispositivo de linguagem incriminador.

Formou-se novo gabinete secreto-misto: decretou-se aí, segundo corre, o assassínio dos Senhores Andradas. A Nova Luz teve igual sentença, que se proclamou o suprassumo da moderação, posto que era pena de morte a faca, ou tiro, ou água tufana. Le general encarregado desta brincadeira dos assassinos acima mencionados, e dos outros para Manoel de Carvalho, Chico doido, Reis \&c. , propôs para emenda à sentença, que por moderação, e piedade, se publicasse, $1^{\circ}$ que era haitiana a Nova Luz; $2^{\circ}$ que os Senhores Andradas haviam prometido entregar o Brasil à Pedro Bourbon. ${ }^{123}$

Observem que há pena de morte para o haitianismo; e que portanto os inimigos da sua Nova Luz já te-la-iam posto no patíbulo (e com razão) se tivessem provas: mas como não as tem são monstros que, caluniando a Nova Luz, e ocultando os autores de São João Marcos e Valença, se mostram coniventes, ou estúpidos. ${ }^{124}$

Interessa notar, sobretudo, que enunciações do Haitianismo girando em torno de agendas cerceadoras de direitos passaram a ser usados por diferentes forças políticas contra seus respectivos adversários. O Aurora Fluminense, em debate com outro adversário político, o jornal $O$ Estafeta, traz outro caso em que o "negócio do Haitianismo" teve como efeito discursivo o incremento do punitivismo e a redução de direitos civis e políticos, como a livre associação. Neste caso a dissolução e castigo de uma associação onde predominavam os Liberais Moderados naquele instante.

No n 14 torna o Estafeta longamente ao negócio do Haitianismo, e atribuiu todos os procedimentos da Assembleia Provincial do Rio de Janeiro a uma força invisível, emanada da Sociedade Defensora cuja dissolução e castigo o Estafeta reclama, para tranquilidade e segura regeneração do Brasil. ${ }^{125}$

\footnotetext{
122 Para uma análise da retórica deste jornal, interpretada como típica das "batalhas linguísticas" de sua época, ver Carvalho (2000, p. 146).

${ }^{123} \mathrm{NLB}, \mathrm{n}^{\mathrm{o}} 158,06 / 08 / 1831$. p. 5 - negrito adicionado.

${ }^{124} \mathrm{NLB}, \mathrm{n}^{\circ} 160,17 / 08 / 1831$, p. 8 - itálico no original, negrito adicionado.

${ }^{125}$ AF, ed. $1039,29 / 04 / 1835$, p. 1 - negrito adicionado.
} 
Percebe-se, assim, que o abuso de poder estatal ou paraestatal encontrava na linguagem do Haitianismo um facilitador para a prática de atos de exceção, incluindo execuções extrajudiciais. Esta conexão entre insultos políticos e práticas persecutórias, de vigilância e controle sobre vidas e corpos de opositores, é denunciada pelo jornal pernambucano Bandeira de Retalhos, de linha política Liberal Exaltada. O editor sustenta que tais expedientes já eram destinados a conter o avanço do liberalismo mais radical durante o reinado de d. Pedro I, "o tirano estrangeiro". Tais manobras discursivas estariam sendo mantidas ou reativadas pelos Liberais Moderados para perseguir seus atuais opositores à esquerda do espectro político, de acordo com estas formulações Exaltadas.

Aqui também se mantinha o hábito de classificar os adversários políticos como “inimigos do Brasil” nos discursos envolvendo o Haitianismo. A perseguição policial, anunciada pela intimidação discursiva e feita em nome da contenção do radicalismo político, era um dos efeitos de poder visíveis neste tipo de uso, em 1832. O redator alerta que seus correligionários estão sendo "mortos, presos, perseguidos e atacados", por denunciarem a "traição" dos Liberais Moderados à "gloriosa revolução de 7 de Abril" (quando expulsara-se o monarca tido como absolutista e antibrasileiro). A disputa, portanto, seria entre duas entidades discursivas frequentemente contrapostas nas narrativas onde aparece o Haitianismo: os "bons brasileiros" e os "inimigos do Brasil”. Daí entende-se sua construção identitária: “O Estrangeiro que ama o Brasil é bom, e honrado brasileiro. O Brasileiro que atraiçoa o Brasil é pérfido, e ingrato, estrangeiro".

Pergunta-vos mais quem foram, os que arrostravam a morte para salvar nesse dia o Brasil atraiçoado, menos do que agora, do ódio do Tirano? Foram os Alpoins; foram os Barcellares; foram os Caetanos; foram os Rodrigues, foram finalmente todos, a quem o Padre Feijó tem mortos, presos, perseguidos, e massacrados; foram todos os alistados no Heróico Batalhão da Pátria; o brioso, e incorruptível Exército dos Exaltados. Pergunta-vos ainda: quais eram as vozes espalhadas pelo Governo da Boa Vista contra os Liberadores desse tempo? Quais eram os apelidos que os colunas ${ }^{126}$ os honravam! Eram os mesmos com que os Moderados, Colunas de hoje, brindam aos Exaltados. Pedro I assoalhava, que os liberais queriam a pilhagem, assassínios, e o saque. Ele apregoava o Haitianismo; ele chamava aos Liberais, Republicanos, Anarquistas, farroupilhas, sem roupa de um para o outro dia. São estes os epítetos com que o Sr. Evaristo Aurora e sua corja brinda hoje os bons

\footnotetext{
${ }^{126}$ Colunas é o termo pelo qual eram designados os defensores do absolutismo durante e depois do reinado de d. Pedro I, quando teria sido criada a sociedade secreta Colunas do Trono para dar sustentação política ao regime do imperador.
} 
brasileiros, os Brasileiros, que não se vendem a taberneiros; os Brasileiros, que tendo indústria, e indústria pingue não compraram casas por patacões de prata. ${ }^{127}$

\section{Corpos negros no discurso do Haitianismo}

Embora a redução ou mesmo suspensão de direitos afetasse, como visto, ao mundo político branco como um todo, era sobre os corpos racializados como negros que a arbitrariedade estatal se transformava em violência física direta, em muitos casos brutal (BRITO, 2008). Há episódios nos documentos analisados que trazem esta dimensão à tona. Neles, o Haitianismo parecia servir como autorização prévia, que normalizava a coerção, o controle e o abuso de corpos identificados como matáveis e torturáveis dentro deste universo discursivo. O biopoder e a colonialidade expressavam-se conjuntamente, portanto, nesses corpos não brancos puníveis. Eram verdadeiros Homo Sacer, no sentido dado por Agamben (2002): aqueles que se pode matar sem cometer um assassinato.

As condições de possibilidade para fazer da exceção a regra eram facilmente ativadas em concomitância com a acusação de Haitiano ou Haitiana. Por exemplo, um jornal chamado $O$ Bacorinho, do Rio de Janeiro, trazia uma mostra disto no ano de 1836. O redator se considera independente e, por isto, vítima dos linchamentos e punições sumárias de todas as forças políticas. "Exaltados, Republicanos, restauradores, Andradistas, Chimangos ${ }^{128}$, tudo queria intervir no castigo malvado" que, no caso descrito, continha um “feixe de varas para trabalhar-lhe as nádegas". ${ }^{129}$

Dali dizia um sujeito da barafunda, e que tinha sido Chimango (e ainda era), olhe que esse ladrão está assim engraxado de preto porque é um refinado haitiano, e deve tomar 800 açoites de uma assentada (...) muitas outras inculpações, todas da natureza semelhante foram feitas ao Bacorinho, e em conformidade do Código foi ali mesmo na Praia condenado a levar 1200 vergalhadas por haitiano, e depois ir para a C. de Correção pelo estelionato. ${ }^{130}$

[E]sse diabo Andradista quis até surrar a Mestre Bacorinho por haitiano no Pau do Pelourinho em Niterói, porque mestre Bacorinho, metido nos cafundórios da barca, suado, e esbaforido, desembarcou na Praia Grande coberto de pó de carvão, muito esfrangalhado, que parecia mesmo um Cabundá gordo, e reforçado. ${ }^{131}$

Corpos negros, especialmente de pessoas escravizadas, podiam ser objeto de abusos e castigos físicos por parte do Estado devido apenas à rumores de Haitianismo. É o que informa o Jurujuba dos Farroupilhas em novembro de 1831.

\footnotetext{
${ }^{127} \mathrm{BR}, \mathrm{n}^{\mathrm{o}} 3,07 / 02 / 1832$, p. 4.

${ }^{128}$ Chimango era uma das maneiras de se referir aos Liberais Moderados.

${ }^{129} \mathrm{OB}, \mathrm{n}^{\mathrm{o}} 2,02 / 02 / 1836$, p. 2.

${ }^{130} \mathrm{OB}, \mathrm{n}^{\mathrm{o}} 2,02 / 02 / 1836$, p. 1-2 - itálico no original, negrito adicionado.

${ }^{131} \mathrm{OB}, \mathrm{n}^{\mathrm{o}} 1,29 / 01 / 1836$, p. 2 - negrito adicionado.
} 
A materialidade dos discursos em torno do Haitianismo ganha contornos palpáveis - e violentos. Neste caso, mil açoites "pela simples presunção d'Haitianismo", no interior da província do Rio de Janeiro, como informa o indignado editorial. Os que sofreram em seus corpos as punições físicas decididas por Tribunais do Estado brasileiro não possuem nomes mencionados, nem por este jornal Liberal Exaltado que deles se compadece. Mas têm cor e status neste regime discursivo: são "pretos" e "cativos".

Tal é o estado da Corte depois que tomou posse a Exma ${ }^{a}$. Regência Permanente pelo Sr. D. Pedro II; e bem disse a Nova Luz que é horrorosa quase sempre a história das Regências em Menoridades de Reis. Cutiladas em pretos cativos é coisa que já se vê sem que faça mossa na gente capitalista d'improviso: diz ela que é boa política espantá-los a ferro, e bacalhau ${ }^{132}$, para que não tenham eles novos intentos haitianos. Em Valença consta, que houve preto, que levou mais de mil açoites, pela simples presunção, d'Haitianismo (que é impotente aqui na Corte, ainda que malvada mão poderosa meneie essa alavanca): e o mesmo Juiz Ordinário, a quem ouvimos esta notícia na Cadeia desta Corte, asseverou diante de várias pessoas, que o haitianismo de Valença foi todo uma pura invenção. Quanto à invenção, podemos afirmar unicamente pelo dito daquele Juiz Ordinário; porém é preciso ter um coração moderado fingido para se não compadecer dos míseros africanos que levam mil açoites por simples suspeitos, e como em paga dos produtos, que para nós arrancam do seio da terra com o suor de seu rosto. Oh! Maldita seja para sempre a política que zomba dos Direitos da desgraça; que vê correr o sangue humano da gente desvalida, sem que sinta emoções exprimidas por lágrimas de dor, lágrimas, que não são d'hipócrita, por que são lágrimas choradas por gente pobre, que não tem que dar, por gente estúpida, que não sabe agradecer, nem distinguir seus benfeitores sinceros, e amigos da Justiça. Nós nunca pudemos crer que víssemos o que vemos, estando no Ministério o Sr. Feijó, que se dizia filantropo por natureza, e hábito. ${ }^{133}$

Este episódio de Valença, interior fluminense, ${ }^{134}$ onde teria havido um movimento de rebeldia dos escravizados na fazenda do Marquês de Baependi, é comentado por outros periódicos, como o Nova Luz Brasileira, também de linha Liberal Exaltada. Em meio a um duro debate com o Aurora Fluminense, revela-se um uso cotidiano do Haitianismo como sinônimo de Crime de Insurreição, mesmo que no Código Criminal de 1830 o termo não apareça textualmente. Este crime só poderia ser imputado a escravizados ou quem os “excitasse". ${ }^{135}$

\footnotetext{
${ }^{132}$ Bacalhau era o nome de um porrete, ou cassetete, usado pela Polícia da Corte para combater a vadiagem, ou seja, o fluxo descontrolado das populações e classes consideradas perigosas, racializadas como não-brancas, escravizadas ou não.

$133 \mathrm{JF}, \mathrm{n}^{\mathrm{o}} 15,16 / 11 / 1831$, p. 3-4 - itálico no original, negrito adicionado.

${ }^{134}$ Para uma análise do "protesto escravo" no Vale do Paraíba, principal região cafeeira do país no século XIX, ver a obra de referência de Viotti da Costa (2010, p. 347-376), citada no capítulo 3.

${ }^{135}$ Promulgado pouco antes da caída de d. Pedro I, o código criminal não poderia, portanto, ter usado textualmente o conceito de Haitianismo, que surgiria meses depois. Este tipo de uso pseudojurídico,
} 
Notem que Aurora fala contudo em haitianos, porém nunca tocou no Conde dos Arcos, e seus discípulos, nem nos fatos de S. João Marcos, e Valença, e S. Gonçalo por onde andou o Padre Malheiros, saído de bordo do Barco de Pedro Bourbon; mas atirando tudo para cima da sua Nova Luz, e para o ex-diplomata que não quer se vender aos aristocratas da Santa aliança. ${ }^{136}$

\section{Insulto político e pessoal: Haitiano como antibrasileiro}

Como visto, a agenda da redução ou suspensão de direitos estava vinculada a perseguições políticas e pessoais no início da Regência imperial brasileira. Cada facção política apresentava uma versão, um significado e um objetivo político próprio para a mobilização do Haitianismo. Nas palavras de um jornal Liberal Exaltado da época, convém "que cada um desses partidos tenha seu haitianismo às ordens". ${ }^{137}$ Neste contexto discursivo, o conceito e suas variantes, como o adjetivo Haitiano, ou Haitiana, também serviam como grave ofensa pessoal de turno nos jogos de linguagem do mundo político branco brasileiro.

Nesta modalidade de uso, Haitianismo não tem sempre uma carga racial tão explícita, mesmo que indiretamente esteja presente, junto como o racismo envolvido nestas locuções. Mas tanto brasileiros considerados inequivocamente como brancos, quanto europeus de dinastias como Bourbon, também foram insultados com o adjetivo pejorativo Haitiano (ou Haitiana) ${ }^{138}$ que aparece, assim, como antibrasileiro, antipatriota, traidor da causa do Brasil - mesmo que não se trate de alguém considerado negro ou revolucionário. Poderia referir-se a pessoas como os Liberais Moderados e suas referências políticas e culturais europeias, por exemplo. Como enunciado pelo Pão d'Assucar em 1835:

Assim, se existem haitianos, eles são somente aqueles homens que afugentam do Brasil a esses mesmos Portugueses e adotivos, levando-lhes a perseguição e a

no entanto, é frequente na época, quando se apelidava de Haitianismo o Crime de Insurreição, previsto no Capítulo IV, sob a seguinte redação: “Art. 113. Julgar-se-á cometido este crime reunindo-se vinte ou mais escravos, para haverem a liberdade por meio da força. Penas - aos cabeças - de morte no grau máximo; de galés perpétuas no médio; e por quinze anos no mínimo; aos mais açoites. Art. 114. Se os cabeças da insurreição forem pessoas livres, incorrerão nas mesmas penas impostas no artigo antecedente aos cabeças, quando são escravos. Art. 115. Ajudar, excitar ou aconselhar escravos a insurgirem-se, fornecendo-lhes armas, munições ou outros meios para o mesmo fim. Penas - de prisão com trabalho por vinte anos no grau máximo, por doze no médio e por oito no mínimo" (BRASIL, 1858, p. 48). A lei de 10 de junho de 1835, que endurece as penas após a Revolta dos Malês em fins de janeiro do mesmo ano, também foi associada ao Haitianismo na época. Ver: Brasil, Coleção Leis do Império, 1858, p. 124.

${ }^{136} \mathrm{NLB}, \mathrm{n}^{\circ} 160,17 / 08 / 1831$, p. 851-852 - negrito adicionado.

$137 \mathrm{JF}, \mathrm{n}^{\mathrm{o}} 10,07 / 10 / 1831$, p. 2.

${ }^{138}$ O "Haitianismo inglês", cunhado pelo Nova Luz Brasileira, $\mathrm{n}^{\circ}$ 147, que será visto adiante, reforça este uso. 
morte. São haitianos esses que toleram os insultos e ameaças dos Ingleses e Franceses que açoitam Brasileiros, e que vindo ao Brasil nos levam o ouro, deixando em seu lugar meia dúzia de trapos, e podres fitas. São haitianos esses que odeiam os Portugueses, e pelo contrário preferem homens de outras Nações que longe de construir edifícios públicos, e promover nosso aumento e prosperidade, chegam a ponto de mandar vir de seus países a própria comida já cozida, e a mesma roupa lavada que vestem! São haitianos somente os que promovem a divisão do Brasil, que o salpicam de sangue fraticida, que não desejam o perdão de leves erros políticos, e pelo contrário querem que graves atentados gozem de indulgência. Haitianos são unicamente esses moderados que tem apregoado a licença em vez de liberdade, a discórdia em lugar de patriotismo, e um sistema efêmero em vez de uma Monarquia Representativa sólida e duradoura, que faça a felicidade dos povos. Estes são os verdadeiros haitianos, que indiretamente conduzem as coisas ao termo do Haitianismo. ${ }^{139}$

Por sua vez, em 1831, o Jurujuba dos Farroupilhas afirmava, em relação a figuras ligadas a antiga administração portuguesa, agora próximas do governo Liberal Moderado da Regência Provisória, que "um preto escravo de um seleiro na Rua da Cadeia, e relacionado com Chalaça, fora achado com insígnias d'haitiano Bourbon". ${ }^{140}$ Em nova reportagem de capa, de outubro do mesmo ano, o jornal rebate, indignado, aos insultos e acusações recebidas de Evaristo da Veiga, redator do Aurora Fluminense. Mesmo para um Liberal Exaltado como João Batista Queiróz, redator do Jurujuba, a alcunha de "cidadão haitiano" era ofensiva demais:

Há três anos que o Sr. Evaristo d'Aurora me provoca de contínuo com as mais incríveis falsidades, e desaforos imundos; e isto faz só por entender que eu era e sou um dos muitos encarniçados inimigos desse Monstro Pedro I, divinizado pelo Farol filho de Mestre José, e amo do filho do ex-Mestre Saturnino, o Sr. Deputado Evaristo Ferreira da Veiga. Esta parva criatura burlesca, e grande víbora, às ordens do Sr. Torquemada qué casá, esse pedantesco empreendedor de palavrões ridículos, insignificantes, ou caluniosos, que espremidos nenhum suco deitam, julga-se autorizado para chamar-me Cidadão haitiano, e revolucionário; Cidadão anarquista d'espelunca com nome coberto de ignomínia; Cidadão que tem ódio à virtude, assim como os hidrófobos tem horror aos líquidos; Cidadão de maça e punhal, homem cruel, e bebedor de sangue, Paulista mais bárbaro ainda que Robespierre! $!^{141}$

O Aurora Fluminense, principal veículo do Partido Moderado, de fato estava envolvido em constantes polêmicas com adversários políticos, nas quais o tema do Haitianismo fazia-se presente. Com frequência, isto se dava na forma de acusações sem provas. O periódico era o de maior tiragem, duração e influência em sua época, literalmente ditando os termos do debate político da primeira metade da

\footnotetext{
${ }^{139} \mathrm{PA}, \mathrm{n}^{\mathrm{o}} 27,07 / 04 / 1835$, p. 2-3 - negrito adicionado.

${ }^{140} \mathrm{JF}, \mathrm{n}^{\circ} 5,23 / 09 / 1831$, p. 1 - itálico no original.

${ }^{141} \mathrm{JF}, \mathrm{n}^{\circ} 12,19 / 10 / 1831$, p. 1.
} 
Era Regencial (ANDRADE, 2012; FLORY, 1977; SODRÉ, 1999). Os termos eram os do regime discursivo do Haitianismo. E o insulto acusatório a forma de sua comunicação. Sobre Evaristo da Veiga, prossegue o Jurujuba:

[M] as quando se trata do seu querido Baependy, Meirelles e Barbacena o vil tartufo escreve (com as ventas pregadas na tal banca, pois é míope) que ainda não os pode denominar haitianos por falta de bastantes provas! E onde estão as provas contra João Baptista de Queiroz? ${ }^{142}$

Com efeito, o exemplo a seguir, novamente de uso difamatório, traz engenhosas formulações e táticas discursivas enunciadas pelos Liberais Moderados, em 1835, contra os Liberais Exaltados. Estes últimos ousavam denunciar o racismo e o preconceito racial no Brasil e por isto eram acusados pela Moderação de incitar ódio racial no país, i.e., de Haitianismo, nesta acepção. As inculpações não precisavam, portanto, apontar precisamente para a preparação de uma revolta concreta. Bastava ao redator da Aurora Fluminense interpretar desta forma alarmista a opiniões políticas adversárias. Como a de que os "homens de cor" seriam "desprezados ou perseguidos" no Brasil escravista, suficiente para Veiga encontrar "tintura de haitianismo":

O Sr. Redator da Novidade encheu-se de furor, porque atribuímos à sua Folha certa tintura de haitianismo, e entre grosseiros insultos, mais próprios (para falarmos a linguagem vulgar) de um muleque do que de um escritor público, ele nos pergunta onde é que na Novidade apareceu a tintura de haitianismo. Recorra o Sr. Redator a alguns de seus $n^{\circ} \mathrm{s}$ antecedentes em que procurou atiçar a rivalidade entre brancos e homens de cor, a pretexto de que os últimos são desprezados ou perseguidos, e o seu espanto deverá cessar. ${ }^{143}$

O próprio Evaristo da Veiga, que também era deputado, registra outros embates nas páginas de seu conhecido periódico, ao debochar da irritação dos adversários contra imputações de Haitianismo feitas nas páginas da Aurora Fluminense. À medida que a retórica derrogatória cresce, os ataques passam do político ao pessoal, em discursos onde a ironia servia a um propósito tático (CARVALHO, 2000). Ao comentar as novidades do "Jornalismo Holandês no Mês de Março" (em alusão aos periódicos que apoiavam a candidatura de Holanda Cavalcanti para Regente, em oposição à Diogo Feijó, candidato dos Moderados) ele reforça o efeito difamatório do Haitianismo em meio a guerra discursiva:

\footnotetext{
${ }^{142} \mathrm{JF}, \mathrm{n}^{\mathrm{o}} 12,19 / 10 / 1831$, p. 1 - negrito adicionado.

${ }^{143} \mathrm{AF}, \mathrm{n}^{\mathrm{o}} 1.032,27 / 03 / 1835$, p. 4 - itálico no original, negrito adicionado.
} 
Enquanto o Eleitor, a Novidade, e a Mulher do Simplício saídos todos da mesma fonte, não podem levar à paciência que se fale em haitianismo, que se tomem providências contra as tentativas desse crime, e um deles ameaça a quem quer que ouse tratar de haitiano a um cidadão honrado, entrelaçado com famílias não suspeitas; o Padre Mestre do Exaltado, lamenta a sorte de uma Nação que apenas saindo do berço se vê já presa de meia dúzia de ineptos; depois de fazer genuflexão a um dos Srs. Andradas, gaba a sentença da ilibação e incontaminalidade do herói da independência. ${ }^{144}$

Os insultos pessoais envolvendo o Haitianismo chegaram a gerar confusões no plenário do Parlamento Imperial. Um dos deputados envolvidos no bate-boca em questão é Joaquim Candido Soares Meirelles, a quem Marco Morel (2017) e muitos relatos da época atribuem participação nos eventos que levaram à cunhagem do conceito de Haitianismo. Os outros deputados envolvidos são José de Assis, do Ceará, e Pedro Fernandes Chaves, do Rio Grande do Sul, que fazem acusações e provocações racistas contra Meirelles em plena Câmara dos Deputados. Ao se defender, ele diz, segundo as notas taquigráficas dos Anais do Parlamento Brasileiro:

O Sr. MEIRELLES nota que não foi ele que chamou a discussão para o terreno em que se acha. Repete o que já disse em outra sessão, porque nisto insistiu o Sr. Pedro Chaves, que não se recorda que tivesse entrado na câmara uma só vez com o ânimo de ofender a quem quer que fosse, e referindo a ocasião em que deu o seu aparte: - Nesse tempo estava e bem tranquilo em Paris, - pergunta aos homens mais irritáveis, aos homens mais suscetíveis, em que podia esta parte ofender a quem quer que fosse, e menos a um partido todo inteiro? Observa que no partido que the é adverso, tem amigos muito íntimos, amigos que ele aprecia e que o apreciam, e por isto não podia dirigir um aparte com o ânimo de ofender a todo um partido, quando nele há indivíduos que são seus amigos. Mas quando mesmo tivesse o ânimo deliberado de ofender ao partido adverso, nem por isto se entenderia que se dirigia a uma pessoa particularmente, e menos ainda que essa pessoa fosse o $\mathrm{Sr}$. Pedro Chaves. A que propósito, pois, imediatamente que o orador deu este aparte, diria o Sr. Chaves - Era a ordem da sociedade haitiana?

Ontem, continua o orador, disse o nobre deputado que não se referia a mim, que o nobre deputado pelo Ceará foi quem pôs este aparte na minha cabeça. Senhores, eu não creio que sejamos tão inocentes, que hoje, na época em que nos achamos de 1831 pra cá, quando se fala em haitianismo, em sociedade haitiana, se não refira tudo isto a Meirelles. Se pois eu acredito que não ofendi com o meu aparte ao partido do nobre deputado, nem a indivíduo algum de que ele se compõe, e menos ainda ao nobre deputado, como disse ele, que desforçando-me eu de semelhante injúria, vim para esta casa com o ânimo deliberado de o atacar caluniar? ${ }^{145}$

Embora este embate aconteça em 1848, já no segundo reinado, ele refere-se a incidentes ocorridos na década anterior. O fato dos demais deputados terem se

\footnotetext{
${ }^{144} \mathrm{AF}, \mathrm{n}^{\mathrm{o}} 1034,01 / 04 / 1835$, p. 2 - negrito adicionado.

${ }^{145}$ Anais do Parlamento Brasileiro, sessão de 27/06/1848, p. 279-280 - negrito adicionado.
} 
insurgido contra a reativação de tais expedientes discursivos mostra que em 1848 o Haitianismo já não fazia mais parte do vocabulário político como era de hábito no início da Era Regencial. Prova disto é que o deputado Fernandes Chaves chegou a ser expulso do plenário por usar o Haitianismo nesta época, mesmo referindo-se a eventos de 1831, em seus ataques pessoais ao deputado Meirelles. ${ }^{146} \mathrm{O}$ acusado acredita que o objetivo político do ataque seria racista: "excluir sistematicamente os homens de cor". Para este tanto "é que se chama sobre eles desconfianças aviltantes, fingidos temores de massacres aéreos, inventados, urdidos e propalados pela soberba, pela intriga e pela perversidade, pela ignorância presunçosa". ${ }^{147}$ A desavença durou por três sessões seguidas, nos dias 17, 23 e 27 de junho de 1848.

Meirelles prossegue com a função política dessa "palavra mágica", o Haitianismo, para chegar à conclusão de que se trata de "charlatanismo". Para o deputado, no Brasil as condições estabelecidas pela colonização escravista portuguesa, "mais humana" e com "mais doçura" que a de outras potências europeias, impediam que aqui pudessem repetir-se as "desgraças que ocorreram na Ilha de S. Domingos". Sua preocupação principal era com a sua honra pessoal, mas também com os efeitos de poder que a verborragia haitianista teria gerado no mundo político, transformando "homens bons em feras": 148

\begin{abstract}
Os charlatães que inventaram essa palavra fizeram acreditar no país que existia uma sociedade de negros de que eu era chefe, que tinha por fim destruir toda uma raça para substituí-la por outra. Esse charlatanismo tem trazido a perversidade, tem constituído homens bons em feras, tem feito os maiores males possíveis: entretanto, convém explicar essa palavra, convém que o país que não é tão ilustrado, conheça o que ela vale, e que ela não pode ter a significação que a perversidade tem dado. A palavra - haitiano ou haitianismo - significa uma ordem que existe, ou existia, em um país que nunca teve nem tem relação com o que se passou ou se passa no nosso país (Apoiados.). ${ }^{149}$
\end{abstract}

Um dos tópicos da discussão entre os parlamentares foi uma menção de Meirelles, que se autoconsiderava "mulato"150, ao deputado Chaves sobre uma sentença que este último proferira quando era juiz em Porto Alegre, quando teria ordenado um número elevadíssimo de açoites para negros escravizados julgados culpados por tentativa de homicídio. Meirelles também o acusara de ser conivente

\footnotetext{
${ }^{146}$ Anais do Parlamento Brasileiro, sessão de 27/06/1848, p. 265.

${ }^{147}$ Anais do Parlamento Brasileiro, sessão de 27/06/1848, p. 265.

148 Anais do Parlamento Brasileiro, sessão de 27/06/1848, p. 280.

${ }^{149}$ Anais do Parlamento Brasileiro, sessão de 27/06/1848, p. 280 - negrito adicionado.

${ }^{150}$ Anais do Parlamento Brasileiro, sessão de 27/06/1848, p. 266.
} 
com a execução extrajudicial de um inocente. ${ }^{151}$ Além de insistir que as penas foram até brandas para o crime cometido (assassinato do próprio senhor), o deputado gaúcho insinua, em sua réplica, novamente o tema do Haiti, detendo-se de prolongar o debate, no entanto, por se tratar de assunto "delicado".

O orador não acompanhará o nobre deputado hoje nessa discussão relativamente a sociedade haitiana; isto tem em si alguma coisa de delicado. Não o acompanhará também na longa história que fez da nobreza do Haiti, limitar-se-á simplesmente a dizer algumas palavras em resposta a fatos que o deputado citou (...) Parece-me portanto evidente que este fato foi trazido unicamente com o fim premeditado de o ferir (apoiados), magoá-lo, e não só magoá-lo, como lançar uma pecha sobre a sua reputação. ${ }^{152}$

Vê-se que o Haitianismo fez parte de intrigas do mundo político oficial, predominantemente branco, mesmo que mantivesse a racialização do discurso sempre presente. E que se utilizavam de provocações racistas e acusações que apontavam para o limite sociorracial da vida política: a "revolução mais negra, e horrorosa", como definiu o Bússola da Liberdade - Periódico Político e Literário, em 1832, ao dedicar um detalhado editorial ao tema. Os insultos e acusações de conspiração são, como de costume, direcionados a Meirelles e outras figuras ligadas ao Partido Moderado.

Não podemos deixar de recomendar muito, e muito aos nossos leitores a leitura de dois pequenos folhetos, que correm impressos. Um do Sr. Meirelles contra o Sr. Silva, outro deste Cidadão Patriota em resposta, e desmascarando o Sr. Meirelles. A matéria contida ou debatida nestes dois folhetos é interessantíssima; nada menos é do que saber se é, ou não certo, que o Sr. Meirelles se ache a testa de uma revolução haitiana. A Fazenda do Sr. Baependy é apontada como o centro: por todas as Províncias se tem espalhado emissários, e traduções do Abade Gregoire, e principalmente para Minas, e Bahia. A nosso modo de pensar, não sabemos, como se safará desta arguição o Sr. Meirelles. ${ }^{153}$

Mais adiante, o periódico pernambucano classifica a Meirelles como um "bajulador da Regência", dentre outras ofensas, que concluíam que ele "tramava

\footnotetext{
${ }^{151}$ Ao defender-se, Chaves descreve o crime, da seguinte forma: "Dois outros escravos, a quem o orador aplicou esta pena, tinham cometido um dos maiores delitos que a nossa legislação reconhece; tinham matado traiçoeiramente a seu próprio senhor. Uma das escravas que dormia na casa, valendose da ocasião em que ele estava dormindo, abiu uma janela, e fez introduzir um escravo com quem tinha relações ilícitas, e ambos foram-se ao senhor que estava no melhor do sono, e com um machado lhe quebraram o crânio e o mataram". Notas taquigráficas dos Anais do Parlamento Brasileiro, sessão de 27/06/1848, p. 282.

${ }^{152}$ Anais do Parlamento Brasileiro, sessão de 27/06/1848, p. 282 - negrito adicionado.

${ }^{153} \mathrm{BL}, \mathrm{n}^{\circ}$ 53, 20/01/1832, p. 4 - negrito adicionado. Para mais informações sobre as desavenças pessoais e políticas entre dois cirurgiões da Santa Casa de Misericórdia do Rio de Janeiro (um dos quais era Meirelles), que teria levado a cunhagem do conceito Haitianismo, durante a troca de acusações públicas por meio de "folhetos” impressos, ver Morel (2017, p. 277-282).
} 
desta maneira contra a Pátria”. O editorial acusa a imprensa política ligada ao Partido Moderado de calar-se sobre o assunto, mostrando sua conivência com esse "crime" (Haitianismo). E denuncia a tática de distração da opinião pública baseada em atribuí-lo aos Liberais Exaltados. Ao final, reproduz-se trecho do folheto de Joaquim Silva contra Meirelles, que dizia ter sido convidado pelo seu colega para adentrar a confraria secreta de "Sócio Haitianos". Sua linguagem mostra o ambiente persecutório e conspirativo deste universo discursivo:

O Snr. Silva termina seu folheto, dirigindo-se ao Snr. Meirelles desta maneira "Saiba o Snr. Meirelles, que eu não ignoro, que estão divididos em Centúrias; que a fazenda do Snr. Baependy é o lugar para onde se hão ir refugiar os da Cidade: que sei de que casa saíram os barris de aguardente, que se deu à Tropa (à 14 de julho) e quem andou visitando as guardas na noite de 15 , e que por sinal caiu do cavalo na travessa do Paço: que fui sentenciado à morte, e que se me fizeram esperas: que os Sócios Haitianos tem adotado por sistema linguagem moderadíssima: mal dizerem de dia do que tramaram a noite, e menos cabarem uns aos outros para não serem conhecidos. Diga agora o Sr. Meirelles, o que quiser, porque não lhe responderei, senão no Júri." ${ }^{154}$

Mas esta linguagem carregada e tensa não é a única dentre as difamações pessoais envolvendo o termo. Algumas articulações políticas em torno de nomeações ministeriais também falavam em Haitianismo. Como notou um periódico político da época: "Diz a Aurora que toda guerra é por causa de empregos [públicos]". Segundo esta visão, os "fingidos sustos de haitianismo" seriam táticas para convencer os "brancos natos" a expurgar da máquina estatal os "mulatos" e "Europeus". Mas “o Sentinela, para sossego da Aurora, não foi, não é nem quer ser funcionário público". ${ }^{155}$

Em outra ocasião, no ano de 1834, o jornal A Mutuca Picante trazia uma seção intitulada "Boatos", onde o colunista faz pequenas notas, por vezes com humor, sobre a conjuntura política. Numa delas, o editor do jornal a Matraca dos Farroupilhas, João Batista de Queiroz, personagem acusado de Haitianismo pelos Moderados, é ao mesmo tempo alçado à categoria ministerial, ironizado por sua linha radical e, por fim, cobrado em termos da abnegação de sua remuneração para tal posto. Neste uso também difamatório, ainda que humorístico, o Haitianismo ressalta postura políticas e raciais consideradas censuráveis por quem pratica esta elocução:

\footnotetext{
${ }^{154} \mathrm{BL}, \mathrm{n}^{\mathrm{o}} 53,20 / 01 / 1832$, p. 4.

${ }^{155}$ SLRJ, no $13,17 / 01 / 1833$, p. 1-3.
} 
Há quem diga que o Sr. Baptista Matraca será nomeado Ministro para tratar com as Autoridades Africanas as condições, com que admitirão os pretos, que se exportarem do Brasil, em conformidade com a Lei de Novembro de 1831. O Haitianismo conhecido de $\mathrm{S}$. $\mathrm{S}^{\mathrm{a}}$ fará sem dúvida que, contentando-se para desempenho desta missão com a ajuda, noutros tempos gramada, não quererá aumentar, com grande ordenado, o peso que já causa um exército de Diplomatas, que povoam a Europa. ${ }^{156}$

\section{Segurança pública, militarização e exceção fiscal}

O Haitianismo também participava, como era de se esperar, dos discursos sobre segurança pública, principalmente no Rio de Janeiro. Chama atenção a articulação, em tais narrativas, de temores raciais e sociais com as agendas de controle populacional e incremento policial, reiteradamente propostas como solução para os perigos narrados. E mais de uma voz associa autorizações para o incremento da força repressiva com liberdade para gastos públicos, como se a exceção penal viesse acompanhada de exceção fiscal também.

Por exemplo, como visto na seção 1 deste capítulo, o projeto de lei produzido pela Comissão da Assembleia Provincial sobre o Haitianismo foi aprovado (em três discussões) e sua redação trazia chamados por "uma vigilante polícia" contra "Africanos" ou "estrangeiros de cor". Aqui também exceção jurídica vinha acompanhada da exceção econômica. Autorizavam-se "todas as despesas necessárias" para este fim devidamente securitizado. A agenda do controle, vigilância e incremento da musculatura do biopolítica estatal era concomitante a colonialidade deste exercício do poder, que a classificava a população conforme critérios de raça, ou "cor":

Art. 3. O Presidente da Província fica autorizado para fazer deportar para fora da mesma todos os estrangeiros de cor de um e outro sexo, compreendendo-se nesta classe os Africanos libertos; e com especialidade aqueles que divagam pela mesma Província, entretidos no tráfico de mascates e pombeiros.

Para este fim os Juízes de Paz, e mais autoridades que exercem com eles jurisdição policial cumulativa, farão prender os ditos estrangeiros de cor, onde que forem encontrados, e os remeterão com segurança à disposição do Presidente da Província.

Todos os Oficiais, Oficiais Inferiores, e Soldados da Guarda Nacional, ou de outro qualquer corpo de força armada, que se negarem à prestação de auxílio que lhes for requerido por alguma autoridade nos casos de tentativas de insurreição, serão presos mesmo antes de culpa formada, e punidos com as penas impostas no art. 128 do Código Criminal.

Art. 7. O Presidente da Província fica autorizado para fazer as despesas necessárias para execução desta Lei, e para manter uma vigilante Polícia de inspeção em todos

\footnotetext{
${ }^{156} \mathrm{MP}, \mathrm{n}^{\mathrm{0}} 10,17 / 10 / 1834$ - itálico no original, negrito adicionado.
} 
os lugares da Província onde julgar conveniente: devendo dar conta de tudo o quanto houver chegado a seu conhecimento e despendido a este respeito, à Assembleia Legislativa Provincial na sua primeira reunião ordinária ou extraordinária, em ofício reservado.

O Pão D'Assucar, que tão veementemente se indignara contra esta legislação, o linguajar e a atmosfera de Haitianismo, por outro lado, concorda com o espírito punitivista e controlador dos corpos racializados como negros. Em comentário à Revolta dos Malês, na Bahia, reproduzido do jornal A Gazeta Comercial, este periódico fornece um exemplo paradigmático de enunciação da governamentalidade em sua época, acompanhada das "medidas mais eficazes" sugeridas para lograr este fim, como "uma polícia ativa e vigilante". Após refletir sobre a origem do Haitianismo e usá-lo de maneira criativa por três páginas, encontra-se uma matéria intitulada "BAHIA" em que a linguagem é de enfrentamento militar permanente, conforme já alertado por Brito (2008):

Passemos agora a considerar por alguns momentos o perigo em que estivemos de ver nossas esposas e filhos mortos desapiedadamente por bárbaros Africanos, se um acidente feliz não estorvasse a execução de um intento tão cruel. Isto bem meditado deve nos horrorizar para que não sejamos tão frouxos e descuidados como até agora temos sido, em tomar a este respeito as medidas mais eficazes, para que outro igual rompimento não nos apanhe de improviso. Parece que as mais óbvias e imediatas que se devem tomar, é estabelecer primeiramente uma Polícia ativa e vigilante, que observe com cuidado todos os passos que os Africanos derem, que pareçam encaminhar-se a conjurações contra nossa existência, para que a tempo se previnam, empregando para este fim todos os meios que mais convenientes forem para se descobrirem intenções tão pavorosas: segundo, termos uma força armada suficiente, que pela sua disciplina, gente escolhida que se compuser, nos inspire confiança, e aos escravos infunda terror, e quando nos seja preciso possa rebater qualquer assalto, que da parte deles nos possa sobrevir. Mas estas providências, que lembramos, menos eficazes se tornarão se continuarmos a tolerar a introdução de novos escravos, porque, se a afoiteza e ousadia que tiveram os Africanos de acometerem pela primeira vez as nossas guardas e quartéis, proveio de se considerarem em avultado número, como é que permitiremos que eles se reforcem com mais recrutamento? ${ }^{157}$

Novamente exceção policial e fiscal aparecem juntas no discurso, autorizando-se "todos os meios convenientes". Note-se que a função da polícia é

${ }^{157} \mathrm{PA}, \mathrm{n}^{\mathrm{o}} 27,07 / 04 / 1835$, p. 3. 
apresentada como infundir terror aos negros e escravizados, para gerar sensação de segurança na sociedade branca e proprietária. Para tanto, mulheres e crianças são utilizadas como mecanismos de apelo discursivo dos males causados por "Bárbaros Africanos". Mais a frente, o autor volta a criticar o tráfico e defende uma "gradual libertação" dos escravizados. Sua preocupação é com o equilíbrio racial do Brasil. O tema é o relativo embranquecimento ou enegrecimento da sociedade brasileira, para que os brancos não ficassem em desvantagem numérica. Pode-se, assim, encaixá-lo no emancipacionismo descrito por Azevedo (2004) e como exemplar da biopolítica e da colonialidade envolvidas nos discursos do Haitianismo: o redator quer praticar uma engenharia sociorracial em escala internacional, atlântica, nada menos. Por isso entende-se que, após criticar a entrada no Rio de Janeiro de mais "Africanos" e "escravos" de outras províncias, ele acrescenta a ideia de ir gradualmente exportando-os de volta para a África, estabelecendo uma colônia brasileira lá para este fim (que ganha nova autorização fiscal neste discurso):

Por isso cumpre à nossa Assembleia Provincial, prover nos meios que lhe parecer mais acomodados a fazer exequível a Lei, que proíbe a entrada de novos escravos, tomando em muita consideração este objeto, não só como muito essencial à nossa segurança, mas como muito necessário para que não se afaste de nós a entrada de trabalhadores livres, que são os únicos que podem cooperar para o progresso, e melhoramento da nossa indústria, opulência, e civilização. Estas são as providências, que mais imediatamente nos parece se devem tomar em nossa defesa; mas que pesado encargo não será para nós se sempre nos virmos obrigados a estarmos em contínuos cuidados pela nossa conservação, e em armas para rebater agressões de escravos, se não principiarmos desde já a cogitar em outras, que tendam a diminuir essa temerosa multidão, que nos ameaça a quase todos os instantes, obrigando-nos a estarmos sempre alerta? O que nos ocorre é a gradual libertação dos mesmos, provendo ao mesmo tempo em África uma colônia para receber aqueles, que se forem libertando por alguma medida geral, medida esta, que os Americanos do Norte julgaram muito necessária para sua própria segurança: outra não menos eficaz, que nos cumpre tomar para que os Africanos não se afoitem mais a nos acometer, é procurarmos aumentar nossa população branca, animando a emigração de estrangeiros da Europa com partidos vantajosos, facilitando a sua naturalização, e igualando-os em direitos aos nascidos, como praticam os Estados Unidos da América do Norte, e as mesmas Repúblicas do Sul. ${ }^{158}$

A Mensagem ao Trono, do mesmo ano de 1835, fruto da mesma Comissão da Assembleia Provincial sobre o Haitianismo, faz, naturalmente, coro a tais discursos. Nela pede-se uma intervenção do Governo central na segurança pública fluminense após o suposto incidente de Haitianismo em Campos dos Goytacazes,

${ }^{158} \mathrm{PA}, \mathrm{n}^{\circ} 27,07 / 04 / 1835$, p. 3. 
principal zona produtiva e escravista da província do Rio de Janeiro. Ao fazê-lo, emprega-se as mesmas argumentações, em tom ainda mais alarmista, "excitando a vigilância, o zelo e a honra do Governo central". ${ }^{159}$ E, não surpreendentemente, a Mensagem termina reproduzindo o discurso da segurança pública ameaçada que, portanto, requer autorização para gastos excepcionais. Diz o texto: "Senhor, o crime não dorme: e este é de tal natureza que cumpre mais do que nunca que o Governo o esmague, e não se deixe prender por acanhadas considerações de despesa, ou de política. O Brasil ameaçado reclama justiça e energia." O tropo da ameaça dá o tom securitizante, acima da política, ao passo que o incremento da disciplina e do biopoder surgem como solução: mais controle sobre corpos e populações. São elaborações e formulações sobre demografia racial em forma de propostas de políticas públicas cujas tecnologias de controle e engenharia social alcançam, também, o nível internacional. A proposta de estabelecimento de uma colônia brasileira na África, como visto, insere-se neste exercício de biopoder e foi retomada pelo Aurora Fluminense num dos raros momentos em que este periódico e o Pão D'Assucar concordaram: no seu racismo expresso na forma de medo branco. Em artigo no qual menciona o "negócio do haitianismo", diz o Aurora:

\begin{abstract}
Sobre um projeto de lei apresentado na Assembleia Provincial da Bahia a respeito dos Africanos libertos, diz o Pão d'assucar algumas coisas que parecem razoáveis, sem embargo de que muitas dificuldades se oporiam à fundação dessa colônia que pretende estabelecer na Costa d'África. Mas como que arrependido de haver tido senso comum por espaço de algumas linhas, ele se apressa a reclamar a dissolução dos Corpos de Permanentes que hoje pertencem às províncias, a reorganização do exército, e a criação de Corpos de Suíços e Alemães, comandados por Oficiais Brasileiros. Forte sanha há de apagar até os vestígios da revolução de Abril, e de repor todas as coisas no estado em que existiam sob o governo de D. Pedro I! ${ }^{160}$
\end{abstract}

\title{
5. Eleições, conspirações e rusgas políticas: o Haitianismo em ação
}

O Haitianismo foi, em grande medida, associado a agendas políticas e manobras desleais nos embates entre os três principais grupos políticos do início da Era Regencial no Brasil. Cada força política possuía uma teoria própria sobre a origem do Haitianismo, fosse como palavra, rumor ou fabricação de revoltas de negros e escravizados como tática para lograr fins políticos imediatos. Nos

\footnotetext{
${ }^{159} \mathrm{AF}, \mathrm{n}^{\mathrm{o}} 1032,27 / 03 / 1835$, p. 4

${ }^{160} \mathrm{AF}, \mathrm{n}^{\mathrm{o}} 1039,29 / 04 / 1835$, p. 2.
} 
documentos pesquisados, não é demonstrado receio algum quanto a um movimento ou rebelião auto-organizada pelos próprios escravizados. Há uma brutal retirada ou negação da agência política dos setores subalternizados neste universo discursivo do Haitianismo, em linha com os alertas de Spivak (1988). O temor é quanto à possibilidade de serem utilizados como massa de manobra, de forma irresponsável, por alguma força ou facção do mundo político branco estabelecido. É neste sentido que se davam as frequentes trocas de acusações e teorias da conspiração sobre o Haitianismo na imprensa política brasileira.

Mesmo os que duvidavam do Haitianismo reproduziram esta linguagem e acusaram seus adversários de algum plano neste sentido. A polissemia, no entanto, não alterava as referências permanentes que o termo trazia: traições e conspirações que beiravam limite racial da vida política. Como veremos, mesmo os que tratavam o Haitianismo como invenção estavam convencidos do poder político que tais rumores podiam produzir. É importante tratar o discurso do Haitianismo, portanto, "em sua positividade", como sugere Morel (2017), "procurando compreender seus significados e usos naquele contexto, bem como personagens e questões envolvidas" (2017, p. 277).

Neste sentido, chama atenção a quantidade de acontecimentos em que o Haitianismo foi relacionado com a realização de campanhas eleitorais e foi tema de capa em dia de eleições no período Regencial. Uma das teorias compartilhada pelos extremos do espectro político branco era a de que o Haitianismo seria uma armação encenada e difundida algumas vezes, entre 1831 e 1835, por setores do Partido Moderado, a fim de espalhar um clima de terror que propiciasse a vitória eleitoral de um candidato considerado enérgico, como o famoso ministro da Justiça Diogo Feijó. Mas havia variações nas teorias e, também, criatividade, raiva e humor nas exposições das denúncias mútuas.

Por exemplo, A Voz do Beribi, periódico de Pernambuco, manifestava-se sobre a eleição regencial de 1835 afirmando haver um plano da Moderação para conquistar os setores mais conservadores da sociedade, a quem o "Sr. Feijó prometia continuar o comércio na Costa D’África”. O Haitianismo seria a contraparte de uma estratégia eleitoral, como prossegue o periódico:

Também por parte da Moderação se prometeu a continuação do tráfico da Costa d'África aos Srs. de Engenho como engodo para votarem no Sr. Feijó. A lembrança é digna do Aristarcho, e da sua gente, que dez vezes apanhada em mentira nem por 
isso se corrige. No Rio de Janeiro se disse, que a perseguição dos pretos, e assoalhamento do haitianismo era invenção dos Moderados para tornar necessário um regente enérgico, o Sr. Feijó. ${ }^{161}$

Esta também era a versão do Pão d'Assucar, sempre reticente quanto às agendas de poder dos Liberais Moderados encobertas sob o linguajar do Haitianismo. Logo após os resultados da mesma eleição, em abril de 1835, o jornal traz na sua capa o seguinte raciocínio:

Que é feito desse Haitianismo denunciado com o estrondo do trovão?! Que é feito dessas participações de Campos, Sessões Secretas, Mensagens, Força armada para Vila de S. Salvador, Suspensões de garantias Constitucionais, acres acusações ao Governo Central, por sua indolência no momento ameaçador? A que se reduziram, pois, tantos e tão espantosos terremotos haitianos?! Parece que 60 votos de Campos a favor do Reverendo Padre Feijó, foi a solução para o problema haitiano dos Goytacazes. ${ }^{162}$

O redator busca provar seu raciocínio mostrando que após terminado processo eleitoral, cessara também a disseminação de rumores sobre Haitianismo.

O silêncio das autoridades e da imprensa política seriam exemplos desta tática dos Moderados, desmascarada, supõe-se, neste momento, pelo Pão D'Assucar, com sarcasmo.

O consta a todos, mas todos em silêncio, não deu outro resultado que o mesmo silêncio, além dos 60 votos dos homens dos Campos, a quem o Céu lhes depare, para sua autoridade, o seu votado!... Não sabemos porque causa o Exmo. Sr. Presidente da Província, que deve estar inteirado de todos os trabalhos haitianos, visto o consta a todos, e com especialidade a S. Ex. Como intermediador da Mensagem e Chefe de Província, não tenha até agora apresentado um só resultado de suas diligências na indagação dos culpados, lugares de suas reuniões, e latitude de seus trabalhos. Confessamos com a ingênua simplicidade de nossa mesquinhez política, que toda essa peça haitiana tem sido para nós misteriosa: porque constando a todos, e ninguém denunciando em matéria de tanto melindre: tantas e tão particulares circunstâncias apresentadas no Manifesto, e ignorantismo do Governo, e de todas as Autoridades secundárias, quando o mesmo Manifesto se apresentava com toda a publicidade, como que já em campo aberto com o inimigo; e por fim o morno silêncio do Governo Provincial, é sem dúvida um arcano que o redator do Pão d'Assucar não pode penetrar!!! ${ }^{163}$

O Aurora Fluminense, veículo semioficial dos Moderados, respondia a cada acusação sobre este tipo de uso político eleitoreiro. Sobre esta mesma eleição, na

\footnotetext{
${ }^{161} \mathrm{VB}, \mathrm{n}^{\mathrm{o}} 16,19 / 06 / 1835$, p. 3 - negrito adicionado.

162 PA, no $30,22 / 04 / 1835$, p. 1 - negrito adicionado.

${ }^{163} \mathrm{PA}, \mathrm{n}^{\circ} 30,22 / 04 / 1835$, p. 1 - negrito adicionado.
} 
qual foram acusados de disseminar rumores ou mesmo de práticas de Haitianismo, o jornal rebatia desta forma, em sua matéria de capa:

É o haitianismo um invento da Moderação para dar votos à Feijó; os fatos melancólicos do Pará são devidos à Moderação e tem por fim dar ainda votos a Feijó. Qual o remédio específico contra estas cruéis enfermidades? Votar no Sr. Holanda Cavalcanti com quem não podem haver mais nem receios de haitianismo, nem atrocidades de 7 de Janeiro. = Assim discorrem pouco mais ou menos, o Eleitor, a Novidade, o Pão D'Assucar e outros; vejamos se discretamente. É a voz de haitianismo um invento dos Moderados? As providências emanadas da Assembleia Provincial do Rio de Janeiro são filhas da influência e arte da Moderação? Basta ler essas providências, basta saber que membros da Assembleia lhes deram iniciativa, para ver-se que semelhante imputação é ou mais pérfida intriga, ou o último recurso dos que se sentem apanhados nas suas ciladas. Os Srs. Clemente Pereira, Manoel José de Souza França e Joaquim José da Silva nunca pertenceram às fileiras da Moderação (...) Note a Novidade que as mesmas suspeitas, nascidas no Rio de Janeiro acerca da existência de uma sociedade haitiana, aparecem há tempo na Bahia e em Pernambuco, aonde contudo o partido Moderado não é o que prepondera, como se pode ver pelo espírito de suas deputações na Câmara temporária \&c. Como pois crer que estas suspeita, que os sintomas de insubordinação da escravatura, que o acontecimento último na Bahia, que a convicção sincera da Assembleia Legislativa do Rio de Janeiro e os resultados dessa convicção, sejam tudo manejos do partido Moderado, para eleição de Feijó? Sem Dúvida, vale isto dizer que todo o Mundo é inepto e sandeu, sendo a sagacidade, partilha exclusiva dos Moderados e do Sr. redator da Novidade. Tão estranha asserção cumpria ao menos que fosse provada. Vemos quanto a Novidade se empenha, por dissuadir a população de quaisquer temores a respeito das tentativas de haitianismo; mas também temos diante dos olhos o empenho com que os cúmplices da conjuração que custou a vida ao Presidente Lobo, afastavam do seu espírito todo o receio, ainda na véspera do rompimento, e a maneira porque o apanharam inerme e desapercebido. Se o haitianismo é puro invento da Moderação, para a eleição de Feijó, como explica a Novidade o vosso voto na Assembleia Provincial? Como, os de muitos membros que nunca fizeram parte do partido Moderado? ${ }^{164}$

Em outra edição, no mês anterior, o mesmo veículo já debatia contra outro periódico, $O$ Eleitor, no qual reafirma as justificativas para o temor do Haitianismo ao tentar negar que seja uma tática eleitoral de seu próprio partido:

Não sabemos o que tem com o negócio do haitianismo os papéis impressos na tipografia do Sr. Paula Britto; que é trave que não lhes passa da garganta para baixo. O Eleitor, novo jornal que tem por objeto sustentar a candidatura do Sr. Holanda Cavalcanti, declara que o boato de haitianismo é agora um engodo da invenção dos Moderados, para forçar os Eleitores a votar no Senador Feijó. Não há intriga mais mal armada! Serão moderados os Srs. Clemente Pereira, Souza França e Silva, assinados no Parecer da Comissão especial que propôs a Mensagem ao Poder executivo, e o Projeto de suspensão de garantias para o caso de insurreição, aprovados pela Assembleia Provincial do Rio de Janeiro? Serão esses Representantes da Província eco ou instrumentos do partido Moderado? O que se

${ }^{164}$ AF, vol. 8, n 1034, 01/04/1835, p. 1-2 - itálico no original, negrito adicionado. 
encontra nos papéis da tipografia do Sr. Paula Britto (ignoramos o porquê) é uma sensibilidade morbífica sobre o haitianismo, um grande medo de que se pateteiem planos que existem nesse sentido, e de que se tomem providências adequadas à importância e gravidade do assunto. Pretende o Eleitor que na sessão secreta da Assembleia Provincial mostrássemos grande audácia contra o haitianismo. Nada diremos nem podemos dizer, quanto ao que se passou na sessão secreta; mas para patentearmos o nosso horror contra semelhantes, detestáveis desígnios, não carecemos das trevas do segredo. Fa-lo-emos sempre em voz clara, alto, e bom som sem recearmos a punição que o Eleitor entende ser audácia grande de nossa parte. ${ }^{165}$

Argumentação que não é suficiente, entretanto, para convencer a quem possuía certeza que o Haitianismo era sim uma tática política da Moderação. O Pão d'Assucar, por exemplo, apresenta sua teoria sobre a origem e disseminação do termo, que teria sido cunhado em uma sessão da Sociedade Defensora da Liberdade e Independência Nacional, ${ }^{166}$ clube político formado em 29 de Março de 1831, uma semana antes da abdicação de d. Pedro I. Membros das três forças políticas frequentavam esta sociedade, mas a prevalência dos Moderados fez-se sentir tanto em suas fileiras quanto nas eleições daquele ano. A origem do rumor nada teria a ver com planos de restauração colonial (conforme sustentado por Liberais Exaltados e, ocasionalmente, pelos Moderados). Segundo esta voz, simpática aos portugueses, o Haitianismo surgira como sugestão de "um sócio" desta Sociedade:

Tratava a Sociedade Defensora sobre medidas relativamente ao Pará, quando apareceu um sócio requerendo, que na circular às Províncias se falasse no haitianismo. Este requerimento que por sua natureza era de grande importância, revolveu a coisa de todos os modos, e o haitianismo ali se desenrolou em toda a sua extensão. Valha-nos Deus, com tanto haitianismo! Entre todos os objetos daquela Sessão, nada houve para nós mais maravilhoso como o que disse um Sócio indagando a origem do haitianismo. Disse o nobre Sócio; que raivosos os Portugueses por haverem perdido o Brasil com a independência deste; e que tendo perdido a esperança de o reaver tinham recorrido à mais atroz vingança para com os Brasileiros, revoltando os Africanos contra os brancos; e acrescentou, que tanto sabia por lh'o haverem dito dois mesmos Portugueses! Nós não assistimos à Sessão da Defensora, mas temos ouvido isto geralmente.

Custa crer que hajam homens que assim se expliquem! Não se pejou aquele Sócio da Defensora quando disse, que dois Portugueses lhe haviam dito, que os Portugueses eram os fautores do haitianismo?! Será crível que sendo bem conhecido o tal defensor por seus feitos moderados, dois Portugueses lhe dissessem tanto, quando fosse verdadeira essa vingança?! ${ }^{167}$

\footnotetext{
165 AF, no 1032, 27/03/1835, p. 5 - itálico no original, negrito adicionado.

${ }^{166}$ Para mais sobre esta influente associação política, ver Basile (2006).

${ }^{167} \mathrm{PA}, \mathrm{n}^{\mathrm{o}} 27,07 / 04 / 1835$, p. 2 - negrito adicionado.
} 
O Bússola da Liberdade também entrava no jogo de especulações sobre o Haitianismo. Em longo artigo de 1832, o jornal reproduzia conversas com interlocutores anônimos nas quais rebate as imputações feitas contra políticos Liberais Exaltados, como Cipriano Barata, acusado (sem provas) de "dizer aos pretos que era tempo dos brancos limparem-lhes os sapatos", dentre outras provocações racistas. O Haitianismo seria um boato para "meter medo", dentro desta estratégia de conter ou desqualificar o suposto radicalismo político dos Exaltados.

Aqui lembrei-me de uma outra conversação que tive com outro amigo a respeito do Redator do Jurujuba, na qual me disse o amigo: este homem é perigoso. Por que? - perguntei eu - porque fala em Lampadosa, e dizem que promove haitianismo. Não creia nisso, lhe tornei, as suas ideias são-lhes administradas pelos marotos Lord Esporas e Pipa, e se não sabe o que é Lampadosa eu lhe digo, Lampadosa foi uma pequena sociedade secreta que minou a tirania de Pedro I, e da existência dela sabe Antonio Rodrigues Martins, sabia o muito honrado João Mendes Vianna, que muita gente que por serem empregados alguns dos seus sócios não referiu nomes, para que não sejam perseguidos; esta sociedade tendo principiado seus trabalhos, trataram os membros de ver que título devia ter, e um dos seus membros por chalaça disse seja a Irmandade da Lampadosa, todos aplaudiram, e pegou a graça; quanto ao haitianismo não tenha susto dele, nós não somos crianças para nos meterem medo com tutus: Replicou meu amigo - Mas ele defende a Robespierre, diz que foi humano \&c. - Que nos importa a nós que ele ache Robespierre humano? disse-lhe eu que a felicidade dele Redator foi não lhe cair nas unhas, e com isto tinha acabado a questão. ${ }^{168}$

Havia teorias que apontavam para autoria da Moderação no Haitianismo, mas que não o consideravam como simples boato ou factoide eleitoral, mesmo que o classifiquem como "fingido Haitianismo". São acusações mais graves, relativas à real tentativa de realizar atos sediciosos, golpistas, como provocar as diferentes tropas militares e forças policias. Isto de fato aconteceu, por exemplo, em 14 de julho de 1831 e novamente e Abril de 1832, no Rio de Janeiro. Em linguagem um tanto críptica, $O$ Rusguentinho entende que tais operações político-militares advinham de uma aliança entre Moderados e Restauradores, que seguiam “instruções secretas" da Santa Aliança para sustentar o "elemento monárquico" e evitar a disseminação da anarquia e do "elemento democrático" no Brasil.

${ }^{168} \mathrm{BL}, \mathrm{n}^{\text {o }}$ 51, 16/01/1832, p. 8 - negrito adicionado. A expressão “Tutu”, derivada do idioma quimbundo ou angolês, refere-se a um monstro ou bicho-papão em cantigas de embalar bebês de origem africana. Foi frequentemente associada ao risco de revoltas de negros e escravizados no Brasil imperial, especialmente na Bahia. Ver a Geografia de Mitos Brasileiros, de Câmara Cascudo (2002, p. 197). 
Note-se que em 31 certos sujeitinhos mandaram Pardos [ilegível] - vai jambo sinhá - , e depois fizeram que eles arruassem noturnamente como valentões de esquina para que a Polícia lhes fosse à mão, como aconteceu outro [dia] quando se legalizaram moderadamente duas Tipografias. Mal os arruadores de 31 aterraram a Cidade e Corte, julgando que serviam à Pátria por conselhos de Pó Fulminante, e do Reverendo discípulo do Belo Senhor, logo apareceu sessão secreta por causa do fingido haitianismo em que dizem haver figurado o Sr. Baependi. Resultou da sessão secreta encarregar-se Manoel Odorico de apresentar como Projeto seu a célebre Lei de Junho, ou a de Outubro; e logo se inventou Municipais Capitalistas com que Feijó ameaçou o Corpo Legislativo. Esses Municipais insultaram aos Srs. Oficiais Soldados de primeira linha com tanto afinco, que parecia haverem para isso recebido ordem superior: apenas o Exército perdeu a paciência houve quem lhes desse de conselho, que fizessem o seu "14 de Julho" que os perdeu, e no qual tiveram parte ativa os do Oriente da Polícia. ${ }^{169}$

O periódico Nova Luz Brasileira, de linha política Liberal Exaltada, grande tiragem e influência, avançava, em 1831, detalhes desta teoria sobre o Haitianismo, incorporada, em grande parte, pelos demais representantes das forças políticas mais radicais. De acordo com esta engenhosa hipótese, haveria um "plano horrível do Gabinete Inglês com a Santa Aliança" para promover uma "guerra civil” no Brasil mediante rumores de "revoltas de africanos". Esta seria uma das instruções secretas deixadas por d. Pedro I ao abandonar o país. O objetivo deste plano seria impedir que o Brasil entrasse para a "família Americana" ou "Terra Americana de Washington", ou seja, evitar que se adotasse a forma republicana de governo, passando a se "governar Americanamente", sem a "maldita reiunada e aristocracia Europeia". Para o Nova Luz, os "inimigos do Brasil" estariam em conluio para destruir nossa "liberdade Americana". O Haitianismo, nesta visão servia, portanto, para impedir que o republicanismo ${ }^{170}$ e o federalismo avançassem no Brasil no bojo do movimento político que expulsou o monarca, tese já proposta por Mello Mourão (2009), como visto no capítulo 3.

Em tal hipótese, ou a federação Republicana custará muito sangue, de que Deus nos livre; ou não se fará senão daqui a muitos anos, ou nunca mais como deseja a

\footnotetext{
${ }^{169} \mathrm{OR}, \mathrm{n}^{\circ} 4,21 / 12 / 1833$, p. 1 - negrito adicionado. Para uma descrição do movimento sedicioso de 14 de julho e demais conflitos entre os diferentes corpos policiais, militares e paramilitares da Corte entre 1831 e 1832, ver Holloway (1997, p. 73-107).

${ }^{170}$ Vale notar que o redator do Nova Luz, Ezequiel Correa dos Santos, em meio ao clima de perseguição política, evitava declarar-se abertamente republicano, mesmo que sua argumentação apontasse firmemente para esta preferência: “A Nova Luz não é nem Republicana, nem aristocrática, nem monárquica; mas não quer ver Carvalho, Maynard, Castro Alvares \&c. numa masmorra com Barata. A Nova Luz quer a Justiça, quer a Liberdade como a quiser a maioria da Nação Brasileira; mas uma maioria não factícia nem movida por manobras, ameaças, ouro, e traição da gente do Conde dos Arcos, da gente de Pedro de Alcântara, com a gente Europeia do Gabinete Inglês, e da santa aliança. A Nova Luz antes deseja federação com fateozim nacional”. NLB, nº 147, 17/06/1831, p. 3-5.
} 
Inglaterra, e os retrógrados e protetores dos membros do gabinete secreto, que fazem haitianadas, por nos tirarem os olhos do Grande WASHINGTON (...) a fim de formarem à sombra, e com apoio do tirano, essa aristocracia infernal, que ainda se pretende erigir entre nós depois do 7 de abril, e à força das manobras Inglesas, e a pretexto de opor barreiras ao haitianismo, que o promovem os protetores da gente do Conde dos Arcos, e do Pedro Vivas Bourbon (...) Estes é que podem mover haitianadas entre nós: estes ambiciosos Regentes em expectativa e por cabala misteriosa, é que tem interesse nas haitianadas, que eles promovem: estes é que tem nas mãos os fios desse labirinto do Conde dos Arcos; o que bem se prova até por lançarem os protetores do gabinete secreto tão feio labéu somente sobre os que derrubaram o tirano contra o voto talvez de jesuitada aristocrática. ${ }^{171}$

O jornal segue expondo sua teoria em um longo artigo. Nesta visão, faz sentido, portanto, falar de um "haitianismo inglês" sendo promovido no Brasil por um "gabinete secreto", que seria composto por Liberais Moderados e Restauradores e visaria armar toda uma série de conspirações ou ameaças de "desordens do Haiti" para alcançarem seu objetivo. A Revolução Haitiana não era um exemplo a ser louvado, mesmo por este Liberal Exaltado, que seguia inspirando-se na Revolução Francesa e acreditando que a "revolta no Haiti" fora insuflada pelos britânicos. Para ele, os que promovem o Haitianismo são "antibrasileiros".

Por ventura quando assim o queira entender a tola maldade que os irmãos brancos, pretos, e pardos, livres da Lampadoza, servirão de força suficiente para tamanho, e tão louco, e infame projeto; não se poderá retorquir com igualdade de razão que alguns da Sacristia do Rosário tem outro poderoso exército, ou irmandade para o proteger o haitianismo inglês, e do gabinete secreto?... Brasileiros, só malvados estúpidos, só escravos do gabinete secreto, e de S. James; só os inimigos da Paz, e Liberdade Brasileira; só os protetores de Cheira, João Bonifácio, Anemuria, Valente, Vilella, Alcântara, Rodrigo Lobo, Tilbury, José Pedro Fernandes, João Vieira de Carvalho, e demais infames absolutistas, e Empregos públicos ladrões, e anti-Brasileiros, que ainda comem os dinheiros nacionais depois do 7 de abril. ${ }^{172}$

Ao defender sua teoria, o editor do Nova Luz, Ezequiel Correa dos Santos, está ao mesmo tempo defendendo a si mesmo e seus colegas de tais acusações e das perseguições que estão sofrendo. Como era uma liderança intelectual dos Liberais Exaltados e defendia uma extinção gradual da escravidão, ele foi acusado pelo oficialismo de ser partidário do Haitianismo, junto com os homens "negros e pardos" que compunham a Irmandade Nossa Senhora de Lampadosa (MOREL, 2017, p. 293). ${ }^{173}$ No entanto, a colonialidade se faz sentir com mais força, uma vez

${ }^{171} \mathrm{NLB}, \mathrm{n}^{\circ} 147,17 / 06 / 1831$, p. 4 - negrito adicionado.

${ }^{172} \mathrm{NLB}, \mathrm{n}^{\mathrm{o}} 147,17 / 06 / 1831$, p. 8 - negrito adicionado.

${ }^{173}$ O historiador Marco Morel situa este embate político: "A história da Revolução do Haiti esteve em voga de maneira insistente, com réplicas, tréplicas e acusações recíprocas. Usado contra liberais Exaltados que eram críticos da escravidão, como os citados Ezequiel, Cipriano Barata e Borges da 
que o próprio acusado faz questão de mostrar que sente horror e pavor frente a uma ofensiva da "força africana". O eurocentrismo, portanto, emerge da própria linguagem pejorativa que o termo "haitianada" possui, que remete a algo considerado como "loucura".

Por ventura será temível essa haitianada no Rio de Janeiro não sendo protegida pelo gabinete secreto, e seus protetores influentes unidos aos ingleses, e santa aliança, que isso promoveram no Haiti, apodados depois pela barbaridade do General de Napoleão, que ainda não gelou o sangue no coração d'Aurora? Por ventura a Nova Luz tem tão pouco senso que não conheça a horribilidade, e parvoíce de uma tal loucura? Por ventura a Nova Luz tem à sua ordem exército, dinheiro, e força para proteger uma grande junção de força africana, com que destrua as da outra raça, e estabeleça um centro de operações militares, e políticas? Por ventura os indivíduos que aqui na Corte tem sido apontados na opinião pública como motores dessa manobra horrenda, e alguns malvados portugueses que por fora tem sido presos pelo mesmo crime tem alguma relação com a Nova Luz? ${ }^{174}$

O mesmo Nova Luz segue mobilizando o Haitianismo por edições subsequentes. Sua oposição ao governo dos Moderados fica cada vez mais forte, permeando as seções "VARIEDADES" E "CORRESPONDÊNCIA", respectivamente. $\mathrm{O}$ racismo segue presente em seu raciocínio que, vale lembrar, corresponde ao mais avançado iluminismo do mundo político branco de seu tempo. São mencionados dois rumores que mais marcaram o ambiente discursivo do Haitianismo: o folheto anônimo sobre o "Sonho do Pico de Itajurú" e a suposta rebelião de escravizados na fazenda do marquês de Baependi, em Valença, no interior do Rio de Janeiro, supostamente desarmada nos últimos instantes antes de sua eclosão.

Fonseca, acusados indistintamente de "haitianistas", o vocábulo assinalava a tendência de abolição imediata da escravidão de modo violento, acompanhada pela Proclamação da República e do extermínio da população branca (ou qualificada como tal). Eram nestes casos, acusações infundadas que visavam acuar e intimidar personagens da cena pública que, efetivamente, se posicionavam pela extinção gradual da escravidão e a favor da forma de governo republicana, mas tratavam tais assuntos de modo cauteloso e não pretendiam, naquele momento, uma ação direta e imediata para alterar a forma de governo, nem buscavam alianças com os escravos, pelo menos na capital do Império" (2017, p. 293).

${ }^{174}$ NLB, no $147,17 / 06 / 1831$, p. 6 - negrito adicionado.

175 Sobre o "Sonho do Pico de Itajurú", ver Azevedo (2004, p. 231-237). Trata-se de um folheto anônimo, impresso em 1831 no Rio de Janeiro, que causou muito impacto no mundo político pósabdicação. Ele trazia uma história mística na qual um profeta alertava sobre uma "onda negra" que levaria à ruína do Brasil em caso do poder estatal ser deslocado pelo "povo alucinado". O folheto fala de "extermínio de todos os Portugueses e Estrangeiros, sem exceção!" e de "união [dos negros] com mestiços para assassinar todos os Brancos brasileiros! Seguidamente, o massacre dos mestiços, e tomar posse das Mulheres, e bens de todos: Os filhos machos que tiverem das brancas serão mortos ao nascimento, e as filhas viverão" (2004, p. 235). 
Disto conclui o autor d'onde extraímos esta pequena variedade, que o Povo nunca se revolta, senão depois de ter sofrido muito, e que sempre o Governo é o culpado, e punível quando se revolta o Povo. Nós esperamos que certa gente, não diga que é puro haitianismo, e anarquia esta variedade tão pequenina (...)

Reflitam agora os Brasileiros não aristocratas, os Brasileiros que não querem subir ao mando sobre cadáveres, e sangue de infelizes, sobre a ruína do Brasil, e de sua Liberdade; e reflitam seriamente que é política de agora espedaçar dois milhões de desgraçados para não haver reformas; que se grita contra Republicanos; e os pretos de Baependi destinavam a horrenda carnagem para o dia da Independência Republicana dos Estados Unidos. Porém os pretos de Baependi não sabem história, e fora injustiça manifesta alcunhar Baependi republicano, ou de federalista antifaroleiro. Notem que os pretos de Baependi tencionavam poupar as caídas para casamento, como estava ordenado na explicação horrenda do Pico de Itajuru; e os pretos de Baependi não sabem ler. Reflitam que a Aurora, que faz artigos contra intitulados anarquistas, e haitianos da Nova Luz, nenhum artigo escreveu acerca da medonha explicação do Sonho do Itajuru (...) Notem que Aurora fala contudo em haitianos, porém nunca tocou no Conde dos Arcos, e seus discípulos, nem nos fatos de S. João Marcos, e Valença. ${ }^{176}$

Teoria similar foi resumida em Pernambuco, pelo jornal Bandeira de Retalhos, em 1832. Desta vez, coloca-se menos ênfase na intervenção internacional e confere-se mais agência às forças políticas domésticas. Sendo assim, o aparecimento do Haitianismo teria sido uma das "coincidências" que o redator suspeita terem sido fabricadas pelo Partido Moderado ao longo do ano de 1831. Nesta visão, a conspiração envolvendo o Haitianismo seria uma espécie de false flag operation, como se diz no jargão militar norte-americano. E somente deixou de ocorrer por ter sido descoberta e denunciada pela imprensa política Liberal Exaltada, verdadeiro alvo daquela agitação.

Agora mostrarei algumas coincidências do partido moderado amigo da lei, e da Ordem para ver se os fatos concordam com o título: apareceu a revolução de 7 de abril; que não foi feita pelo Regente Costa, Paula e Souza, Feijó, Evaristo, etc. etc. mas sim pelos malvados anarquistas (como os chama o Redator da Aurora). Subiram os moderados ao mando; quais seriam seus primeiros cuidados? Tratar de fomentar o 14 de Julho (esta matéria será desenvolvida n'outra ocasião) para com ele romperem o pacto secreto que tinham feito com o Senado, segundo a voz pública, e por meio deste desacreditarem os verdadeiros Catões do Brasil, um Castro Álvares, um João Pedro Mainard etc. e também os corajosos patriotas Rodrigues, Epifanio, Silva, Gomes, Reis, Ezequiel, Queiroz, e outros; e para melhor conseguirem os fins apareceu o Haitianismo, promovido por eles moderados, tanto, que, sendo um anarquista o que descobriu a horrenda conspiração, ficou por isto mal-visto, e o malvado moderado que a promoveu é do seio da Regência, e da súcia de Evaristo Ferreira da Veiga. Ainda desta vez falhou o plano, e preciso foi a segunda Bernarda da Ilha das Cobras para também nela ser envolvido o infeliz Velho Barata! Sim, Barata, tu devias ser assassinado por mãos

${ }^{176} \mathrm{NLB}, \mathrm{n}^{\circ} 160,17 / 08 / 1831$, p. 4-5, negrito adicionado. 
de vis assassinos do Clube do Redator da Aurora!!! em prêmio de 40 e tantos anos de serviços prestados à tua Pátria, a despeito de masmorras, ferros e tirania!!! Deus imortal, até quando a virtude e o patriotismo serão crimes para a moderação? ${ }^{177}$

O periódico Liberal Exaltado A Malagueta também reitera a opinião sobre a responsabilidade dos Liberais Moderados na disseminação deste linguajar, ao comentar de passagem que "ainda menos custa, ao Sr. Evaristo declamar contra o Haitianismo que ele mesmo promoveu, talvez sem querer". ${ }^{178}$ Antipatriotismo, perseguições e disputas políticas cotidianas também são mencionadas pelo periódico $O$ Rusguentinho, como visto acima. Nesta visão, concorda-se com a hipótese de que o Haitianismo fizesse parte, sobretudo, de uma estratégia conjunta dos Moderados e Restauradores.

O Brasil quer Liberdade, e paz: e há de tê-la, dêem as voltas que derem: a terrível anarquia que sofrem as monarquias da Europa já tem nos feito ver que anarquia não é moléstia de Repúblicas; e que também a sofrem Monarquias. Sete Províncias ao Norte, não querendo mais sofrer anarquia contra a Liberdade, nem agrilhoar o Brasil em cadeias de ouro fundidas, manhosa, e politicamente nos Empréstimos, e Tratados, estão ligadas para terem Liberdade, paz, Monarquia Americana não aristocrática e livre e comércio, sem anarquia, nem mamação, nem restauração, nem despotismo, Militar, ou Eclesiástico-inglês (Sr. Feijó) com Ditadura, ou República de tanga, e alfanje. Nós sabemos o que fazem Republicanos como Fructuoso, e Ditadores como Francia do Paraguai: nem com haitianismo, e Restauração e Instruções Secretas, Sr. Evaristo terão Rusgas e Maioria na futura Câmara os que nos querem dar Liberdade de Pedro I, ou Liberdade do Relatório de Feijó. Brasileiros! Vinguemo-nos de Chimangos, e Restauradores servindo a Liberdade sem Rusgas. Viva a Pátria. ${ }^{179}$

\section{Haitianismo e democracia racial}

O debate político da Era Regencial também se utilizou do Haitianismo, como era esperado, para encenar controvérsias diretamente ligadas à questão racial no Brasil pós-colonial. São feitas diversas proclamações sobre como os "pretos" e

\footnotetext{
${ }^{177}$ Em novo, e longo, artigo, a Nova Luz Brasileira volta a acusar a Aurora e os Liberais Moderados de promover o Haitianismo para perseguir os Exaltados: “A Aurora então pedia golpes de Estado ao que se criou, como esse da Bahia contra o Snr. Barata; e ensinava que se fosse caluniando, que as máscaras de carvão sempre sujam; e andou muito na balha o haitianismo da Lampadoza, mas não se falou em Baependi”. NLB, 158, 06/08/1831, p. 4. Sobre a rebelião da Ilha das Cobras no final de setembro de 1831, ver Holloway (1997, p. 90-92) que, no entanto, admite acriticamente a versão oficial sobre a participação de Cipriano Barata no incidente, quando teria convencido seus carcereiros e guardas a juntar-se à rebelião.

${ }^{178} \mathrm{AM}, \mathrm{n}^{\circ} 144,25 / 02 / 1832$, p. 3 - itálico no original.

${ }^{179} \mathrm{OR}, \mathrm{n}^{\circ} 04,21 / 12 / 1833$, p. 8 - negrito adicionado.
} 
"pardos" deveriam se comportar politicamente, segundo cada voz (branca) que os orientava a partir das respectivas imprensas partidárias. A colonialidade do poder fica mais explícita em tais exemplos.

Por outro lado, o Haitianismo também foi usado como dispositivo facilitador da unidade entre brancos durante momentos de disputa intra-elites. Em outros casos, o conceito era invocado para contrapor Brasil e Haiti no sentido de sugerir que as relações raciais e a própria escravidão seriam mais amenas no primeiro país do que no segundo. ${ }^{180}$ Mesmo que já contestada em sua época, com veremos, faz-se muita questão de enfatizar a ausência de discriminação racial explícita no texto da Constituição e das leis brasileiras, além de outros argumentos interessados em transmitir a ideia de no Brasil haveria uma capacidade de manejar os conflitos sociorraciais de maneira mais harmônica e eficiente do que em outros espaços. O Haitianismo participa, assim, da produção de um discurso sobre a identidade racial da nação e emerge como uma tecnologia de poder político.

Para alguns, haveria um saber ou cultura, juridicamente positivada, que faria do risco de Haitianismo no Brasil algo baixo, ou seus rumores infundados, justamente por conta desta embrionária democracia racial. Tudo em meio à escravidão branca sobre negros. Há uma engenharia social complexa e bemsucedida neste tipo de discurso, que encontra uma formulação paradigmática em artigo dedicado exclusivamente ao seu tema, pelo Aurora Fluminense, em 1835. O Liberalismo Moderado de Evaristo da Veiga encontra na defesa da propriedade privada escravocrata uma das provas desta suposta igualdade racial.

\section{RIO DE JANEIRO}

Tem-se procurado confundir $=$ haitiano com homem de cor $=$ haitianismo $=$ com um acidente em que nem a Constituição nem a Razão estabeleceram motivo de diferença. Sabemos bem quais são os fins daqueles que arranjam essa confusão estudada, e o afinco que sem emprega em reunir todos os pardos num só grupo a parte, fazendo-lhes acreditar que sua causa, os seus interesses são alheios aos do resto da Sociedade. No entanto, não cremos que tão funesta cizânia possa grassar entre nós: os pardos, no número dos quais há pessoas de consumadas instrução e muita gente de siso, não ignoram que eles não tem no Brasil as queixas que exasperaram por exemplo os homens de cor em S. Domingos, nem mesmo as que na América do Norte deve trazer o isolamento e desprezo em que está posta essa parte da população. No Brasil, as coisas se passam muito diversamente: quer no tempo do Governo absoluto, quer sob o regime constitucional, nenhuma diferença legal foi estabelecida entre os brancos e a gente de cor livre. Alguns prejuízos da educação a tal respeito, que acham origem na existência da escravatura e nas castas

${ }^{180}$ Como visto no capítulo anterior, este viria a ser justamente o argumento de Gilberto Freyre (2004), um século depois, assim como Marquese (2006) e Berbel e Marquese (2007), atualmente. 
a que a escravatura pertence, perdem todos os dias da sua força, e cedem o campo aos triunfos da Filosofia. Não há maior iniquidade do que confundir homem de cor com haitiano: dos homens de cor livres, muitos tem escravos, e são tão interessados como os nossos Cidadãos, em que as ideias do feroz haitianismo não triunfem. Pardos con[ilegível] nós em que o horror a semelhantes tentativas não pode ser excedido, e que tem mesmo prestado serviços importantes ao País, indicando as fontes do mal, e mostrando quais tem sido a sua marcha e os seus progressos; no entanto que sobre dois brancos, escritores bem conhecidos pela exageração de suas doutrinas, recaem justificáveis suspeitas de que trabalham em favor do haitianismo. Ao menos tem sido eles por vezes acusados de semelhante crime e não puderam até agora lavar-se da imputação. ${ }^{181}$

Nesta lógica, portanto, brancos podem ser "Haitianos", por serem radicais, mas nem todos os "pardos" são rebeldes em potencial. Apesar disto, ele reconhece que há uma "casta" a qual pertence a escravatura. Sua argumentação possui, portanto, pontos de silêncio ao naturalizar a escravidão sobre negros, uma vez que não ser escravizado era o primeiro privilégio racial dos brancos. Seu receio principal é de criar-se um Estado dentro do Estado, em caso de reunirem-se os não brancos todos num só grupo à parte da sociedade. Veiga prossegue com seu Liberalismo Moderado, cuja forma de racismo passa pelo esforço de negação da hierarquia racial da sociedade brasileira. Mesmo que tal hierarquia fique patente em seu texto inteiro, a começar pelo tema ao qual dedica sua reflexão. Tal negação, contudo, é de "interesse comum do Brasil, o da nossa pátria":

\begin{abstract}
Não equiparemos o que é filho ou de fanatismo político ou de depravação de alma, com um acidente de que ninguém é culpado, e que não torna menos estimáveis quantos são merecedores de estima ou por suas virtudes cívicas, ou por seus talentos. Não fazemos corte a esta ou aquela casta, a esta ou àquela classe da Sociedade, e bastante o havemos mostrado, combatendo sem cessar o espírito de classes que a Retrogredação tem querido manter contra o fim da Comunidade. Mas não podemos sofrer que a pretexto de defender os direitos e a causa dos homens de cor, se lhes esteja fazendo a mais cruel injúria, e se empenha numa tática perversa, para separá-los da massa Social, formando no Estado um novo Estado. Amalgamar todas as prevenções, todos os interesses mesquinhos em um pensamento e interesse comum que é o do Brasil, o da nossa pátria, deve ser todo o afã dos amigos da prosperidade do país e da justiça. Quem a isto prefere ou injustos ressentimentos, ou cálculos de ambição privada, não é digno do nome de patriota. Pode ser útil em Governo livre que a Nação se divida em partidos, contanto que estes não lancem mão da violência e dos meios ilegítimos; mas nunca pode deixar de ser aí funesto que a população se ache dividida em castas rivais, uma inimiga da outra, e cujo rancor muito venha assim a ser eterno, por que os acidentes da natureza que os separam, nem mudam, nem se modificam. Nada de confundir haitianos com homens de cor. ${ }^{182}$
\end{abstract}

${ }_{182}^{181} \mathrm{AF}, \mathrm{n}^{\mathrm{o}} 1036,06 / 04 / 1835$, p. 2 - itálico no original, negrito adicionado.

${ }^{182} \mathrm{AF}, \mathrm{n}^{\circ} 1036,06 / 04 / 1835$, p. 3 - negrito adicionado. 
O tortuoso argumento de Evaristo da Veiga é compreensível nos marcos de um liberalismo que é parte da mesma sociedade em que há escravidão racializada. Percebe-se o esforço discursivo de construir uma desracialização do Haitianismo (sintetizada na última frase) paralela à desracialização das relações jurídicas e econômicas Brasil, segundo tal lógica argumentativa. $\mathrm{O}$ redator do Aurora Fluminense já havia exibido esta postura em número anterior: "As nossas opiniões em semelhante matéria são muito conhecidas: se não somos haitianos, não queremos também por outro lado as diferenças de castas, e firme nas teses da nossa Constituição, aborrecemos miseráveis rivalidades de cores", ${ }^{183}$ afirmava. E como visto na seção 3 deste capítulo, o Aurora, $\mathrm{n}^{\circ} 1032$, já criminalizara a opinião do $A$ Novidade "que procurou atiçar a rivalidade entre brancos e homens de cor, a pretexto de que os últimos são desprezados ou perseguidos” no Brasil.

Debatendo diretamente sobre este ponto, o Sentinela da Liberdade no Rio de Janeiro afirma que "[a]o ouvir, e acreditar, na Aurora não há brancos no país, todos são, segundo ela, mulatos que se fingem brancos". ${ }^{184} \mathrm{O}$ jornal está rebatendo uma acusação, feita pelo rival, de que estaria "subi[indo] nas costas dos outros (mulatos) para tirar partido" para si. Ao desenvolver sua indignada resposta, o Sentinela argumenta que tanto conservadores quanto Liberais Exaltados já haviam se pronunciado contra a escravidão ou feito gestos em direção a maiores direitos para os "homens de cor", mas quando "um mulato advoga a causa de outro mulato", começa-se a falar em insurreição, Haitianismo e outras "intrigas" e "calúnias". Trata-se, portanto, de uma linha de demarcação exclusivamente racial, carregada de colonialidade no Brasil pós-colonial. Em operação, uma regulação do debate público, autorizando quem pode praticar atividade política e intelectual livremente; e vedando a quem não pode.

Coisa assas remarcável! O Sr. José Bonifácio de Andrada e Silva, o mais humano e melhor coração de todos os irmãos, fez um discurso para ser recitado na Assembléia Constituinte, discurso que corre impresso, no qual depois de haver ardente e filantropicamente sustentado a causa dos pretos escravos; diz: "se eles são homens como nós (isto é, brancos) se pensam e sentem como nós etc., não foi tratado de haitiano, não foi acusado de fautor da República de negros, não se tocou a chamada, nem se gritou às armas. Porém ele podia fazer, era sem suspeita. O Sr. João Batista de Queirós, branco, disse na Nova Luz e no Jurujuba que os homens de cor eram perseguidos, metidos em masmorras etc. Não houve alarma na Cidade; e não houve circulares aos Juízes de Paz para embaraçar a circulação do

183 AF, no $1032,27 / 03 / 1835$, p. 4.

${ }^{184}$ SLRJ, no $13,17 / 01 / 1833$, p. 1. 
haitianismo. O Sr. May, na sua Malagueta, escreveu diversos números advogando a causa dos homens de cor; disse que o governo os perseguia, que os metia na obscuridade: não houve rebate, não se gritou às armas! O Exaltado tem avançado as mesmas proposições, tem sustentado o mesmo princípio (...) [o] Sr. Feijó fez um Código em benefício dos escravos, faz nele brilhar os santos princípios de Religião, de Moral, e de humanidade, não é proclamado haitiano, não é tido como republicano no Haiti! Mas todos esses Srs. podem sentir, podem ser humanos, podem dar elastério às moles fibras de seu coração, porque não passam de sonhadores, de visionários, ou mesmo inconseqüentes! Um mulato advoga a causa de outro mulato, não ousa mesmo falar em seus pais, se os teve pretos, e o que se faz? Insurreição, às armas! Os negros se movem, às armas! Contra os haitianos! Ah, perfídia! Ah, perversidade! ${ }^{185}$

$\mathrm{O}$ argumento Liberal Moderado sobre igualdade racial no Brasil escravista é retomado, uma década depois, no bate-boca entre os parlamentares Fernandes Chaves (RS) e Joaquim Meirelles (RJ), que responde a incriminação de ser o inventor do Haitianismo (não da palavra, mas da suposta conspiração em 1831). ${ }^{186}$ Meirelles teria sido alvo de tal acusação por causa de episódios em que se colocou contra a discriminação racial em seu ambiente de trabalho, além de iniciativas filantrópicas como a criação de uma "escola para negros e pardos" pobres na capital do Império (MOREL, 2017, p. 292). Ao responder no plenário da Câmara dos Deputados, ele novamente tenta desracializar discursivamente o sistema jurídico brasileiro, ao passo que mostra indignação justamente pela suposição racial insultante imputada a ele e outros "mulatos de brio e honra":

Ora, se todos os que nascem no Brasil são cidadãos, quer sejam ingênuos ou libertos; se todo o cidadão pode ser admitido aos diversos cargos da nação sem outra diferença que não seja de seus talentos e virtudes, se a lei é igual para todos, quer proteja, quer castigue, se são abolidos todos os privilégios, os privilégios de casta, só sustentados os que estão ligados aos cargos por utilidade pública; como, senhores, se proclama em boa fé haitianismo no Brasil? Não se conhece pelo contrário mui palpavelmente o que não quer o nobre deputado pelo Rio Grande, e os que com ele pensam, é a execução da constituição do país, feita no país e para o país?

(...) Nada há, Sr. presidente, para um mulato de brio e honra, de mais aviltante, de mais insolente, de mais ignóbil, do que recear-se seja sinceramente, seja com hipocrisia, que os cidadãos homens de cor (com energia) se liguem a escravos (apoiados, muito bem) para obterem aquilo de que efetivamente gozam (apoiados; muito bem) sem revoluções de raças, sem massacres (apoiados; muito bem), como que os direitos que, como a todos os brasileiros, a constituição deu aos homens de cor não sejam mais do que suficientes para fazer a uns conter-se nos limites da obediência... ${ }^{187}$

${ }^{185}$ SLRJ, no $13,17 / 01 / 1833$, p. 2 - itálico no original, negrito adicionado.

${ }^{186}$ Para mais detalhes sobre esta hipótese acerca de Meirelles, ver Morel (2017, p. 258-303).

187 Anais do Parlamento Brasileiro, sessão de 23/06/1848, p. 265 - itálico no original, negrito adicionado. 
Em sessão posterior, Meirelles desenvolveria seu raciocínio sobre a quasedemocracia racial no Brasil escravista. Seu ponto de vista é baseado justamente no elogio da colonização portuguesa e seu legado para o Brasil pós-colonial. Fica nítida, outra vez, a colonialidade do poder manifesta pela própria tentativa de negar o racismo neste espaço, via afirmação de uma suposta neutralidade jurídica racial. Após afirmar, como visto, que "a palavra - haitiano ou haitianismo - significa uma ordem que existe, ou que existia em um país que nunca teve nem tem relação com o que se passou ou se passa no nosso país", Meirelles elabora seu posicionamento com imagens idílicas sobre as relações raciais luso-brasileiras e a conclusão de que estimular a segregação racial juridicamente era uma postura "impolítica":

"As colônias portuguesas e as colônias espanholas, principalmente as primeiras, foram sempre regidas pelas mesmas leis com que os portugueses eram governados. Esta nação foi a mais humana, foi aquela que governou com mais doçura as suas colônias. As outras nações que tem colônias na América as governaram, ou ainda as governam, com leis bárbaras e de exceção. Os portugueses davam às suas colônias os mesmos tribunais, e os próprios escravos eram julgados pelos mesmos códigos, e aplicavam-lhes as mesmas penas com certas diferenças. Os senhores não tinham direito de vida e morte sobre seus escravos: não havia diferença na legislação do Brasil entre tal ou tal espécie de cidadãos antes de sua independência, e muito menos depois dela; a única diferença era entre nobre e plebeu; havia nobres de todas as cores, havia nobres pretos, homens de cor e homens brancos. Não tenho ideia de nenhuma lei que fosse feita para o Brasil senão a lei pragmática do reinado de $\mathrm{D}$. João $\mathrm{V}$, que estabelecia diferença no vestuário para homens de cor e os pretos. Mas quatro meses depois de promulgada esta lei na metrópole, foi ela revogada por um alvará, porque se reconheceu a injustiça e a impolítica de tal legislação, que não chegou a ter execução no país.

$\mathrm{O}$ orador passa a narrar algumas disposições do regulamento excepcional por que eram regidas as colônias francesas nas Antilhas, e cita o motivo que deu lugar às desgraças que ocorreram na Ilha de S. Domingos, e pergunta que relação tem aquilo que ali se passou com o que tem passado no Brasil, onde nunca houve lei de exceção no tempo mesmo do absolutismo, e onde existe uma constituição em que não se diz uma só palavra a respeito de cidadãos desta ou daquela cor. ${ }^{188}$

Já o Jurujuba dos Farroupilhas, fiel à sua tese internacionalista sobre o "haitianismo inglês" e da Santa Aliança, queixava-se, como visto, das perseguições contra seus correligionários Exaltados, que estavam sendo acusados pelos Liberais Moderados de "haitianos, quando pedem reformas à bem dos Pretos"189. Mesmo assim, ele deixa nítido que sua política racial enxerga nos "homens livres" e nos "brancos" a parte mais importante da audiência que pretende cativar. ${ }^{190}$ E ratifica

\footnotetext{
${ }^{188}$ Anais do Parlamentos Brasileiro, sessão de 27/06/1848, p. 280 - negrito adicionado.

${ }^{189} \mathrm{JF}, \mathrm{n}^{\circ} 5,23 / 09 / 1831$, p. 3.

$190 \mathrm{JF}, \mathrm{n}^{\circ} 10,07 / 10 / 1831$, p. 3.
} 
sua sensação de indignação quanto a ofensa sofrida afirmando que "vida de escravo não é vida que eu viva". ${ }^{191}$ Em suma: não obstante seu radicalismo político, não quer ser classificado como escravizado, menos ainda como "Haitiano".

A racialização pejorativa embutida no uso do Haitianismo fica nítida em sua descrição como "República de Tanga e Alfanje", nesta detalhada formulação do Jurujuba. A colonialidade expressa-se, portanto, pela contraposição binária (arcaico/moderno) do Haiti com a ideia de Brasil que, por oposição, deveria ocupar o lugar hierarquicamente superior também no discurso Liberal Exaltado. O lado moderno caracteriza-se por "comércio, a lavoura, finanças", em oposição ao arcaísmo da "tanga e alfanje”. O que o autor busca evitar, embora sua linha política seja a mais radical de seu tempo, é o "espírito de classe" em caso de intentos ou rumores de Haitianismo. Sua teorização é elaborada (e criativa):

Convém que alguns pardos, e caboclos se finjam republicanos de tanga, e alfanje, e manobrem haitianismo, e forte perseguição aos chumbos, que estão a nosso soldo com os de Pedro II. Por quanto chegando a irritação a este ponto os homens de juízo, e patriotismo, que não querem vinganças, e anarquia, abandonam a causa pública, e logo os velhacos, e tolos da nossa confraria tomam a direção de tudo às nossas ordens, e Adeus Brasil, e vão de cima as Instruções Secretas. Havendo irritação, e vinganças, definha o comércio, lavoura, e finanças; e logo os homens deste ofício unem-se à nós contra a liberdade, que eles amaldiçoaram os chumbos, e os Brasileiros ricos se unem, e não dão aos pobres dinheiro a ganhar: os pobres com fome, irritados, se deixam iludir, por mais patriotismo puro que possuam: os Espiões da Santa Aliança darão dinheiro para manter a República militar de tanga, e alfanje: estes por ambição, e espírito de classe matam aos chichelos de Pedro II com a chumbada das tavernas: estes com os de Pedro II matam aos de Pedro I, e aos brancos, e pardos carvalhistas iludidos: assim evitamos a felicidade da Nação Brasileira; que cansada de tantos desastres, e tendo população muito mais pequena do que as Américas ex-Hespanholas se unem ao partido Bourbon e Orleans, e Meternique, e Welington, e fica arruinado o Comércio português, arruinada a liberdade brasileira, e arruinados os malvados chichelos de Pedro II, e se também ficarem por terra os de Pedro I com a chumbada, não se lhe dá disso a Santa Aliança, contanto que medre o monopólio estrangeiro, contanto que se crie aristocracia militar no Brasil, contanto que ele fique fraco, e retalhado, contanto que vençam as Instruções Secretas para revolucionar o Brasil, e as Américas, e nelas estabelecer famílias reiunas da Europa, ou pelo menos se arruinar, e atrasar as Américas por muitos anos. Homens brancos, e pardos livres, que sois amigos da liberdade, e prosperidade do Povo Brasileiro: homens livres de qualquer parte do Mundo, que habitais o Brasil, e amais a liberdade: uni-vos, abri os olhos à gente de bem; fazei ver que as vinganças nos perdem; e salvemos o Brasil para refúgio dos homens Livres. ${ }^{192}$

${ }^{191} \mathrm{JF}, \mathrm{n}^{\circ} 15,16 / 11 / 1831$, p. 5.

${ }^{192} \mathrm{JF}, \mathrm{n}^{\circ} 10,07 / 10 / 1831$, p. 2-3 - itálico no original, negrito adicionado. 
O também Liberal Exaltado Bandeira de Retalhos, de Pernambuco, trazia formulações semelhantes sobre o Haitianismo. Note-se que o tema da união entre as diferentes partes das elites, em função de um risco social e racial comum. Neste caso, acusa-se os Moderados de promover "intriga das cores" para angariar apoio dos antigos absolutistas, constituindo-se, portanto, em um dispositivo de colonialidade da forma de exercer poder naquele momento. Mas, ao fim, enunciase a mesma tese do Aurora Fluminense sobre igualdade jurídica racial no Brasil escravista, agora por um de seus opositores políticos também. Afinal, aqui os "pretos" não seriam tão maltratados como os "escravos dos Franceses do Haiti":

Vejamos o que se passa na nossa Província, logo depois da rusga de Olinda, que foi em uma sexta-feira e findou no Sábado, na qual não se perseguiu coluna e traidor algum, na segunda-feira seguinte apareceu o Sr. Thomaz Lins Caldas, e o Sr. Colló, dizendo aos Srs. Major Francisco Antonio, e José Tavares Gomes da Fonseca, que era preciso muita união visto que os pretos e as cores eram muito temíveis (note-se que então não se sabia nada da corte, e nem as intrigas e planos se tinham espalhado, e por conseguinte era obra já há muito encomendada, o plano velho do gabinete secreto, que ainda hoje trabalha) tudo com o fim de obstar que os Pernambucanos livres tratassem de punir as traições, e crimes, dos perversos absolutistas, e desta forma fazerem-se eles e os maus Portugueses necessários. Pergunto eu: quando existia o Tirano Pedro I e o partido colunático massacrando os liberais não haviam as mesmas cores? Haviam; e por que não temiam, e agora temem? É porque agora convém dividir para Imperar; pois conseguindo-se segurar o plano, enforcam brancos, pardos e pretos, e não há temor do Haitianismo: por tanto Brasileiros, não vos iludais com uma marcha tão cediça. Os pardos e pretos livres do Brazil gozam pela Constituição dos mesmos direitos e garantias que gozam os brancos, e por conseguinte não são os escravos dos Franceses do Haiti. ${ }^{193}$

O Rusguentinho também entrava fundo no debate racial, sentindo-se autorizado a dizer o que os "pardos bons" deveriam fazer ou deixar de fazer politicamente, e por quais líderes deviam guiar-se. Ao fazê-lo, este periódico ajuda a perceber a importância das reticências de Spivak (1988) e Said (2003) quanto a possibilidade das vozes subalternas se autorrepresentarem discursivamente, diante de uma brutal assimetria de forças e recursos que fala por ou sobre elas. Mesmo sendo opositor ao Liberalismo Moderado, este periódico recaía no mesmo

\footnotetext{
${ }^{193} \mathrm{O}$ jornal segue adiante completando seu raciocínio sobre "intriga das cores": "Tendes o exemplo de um Luiz Nogueira, Ângelo Bizoiro, José do Ó, Manoel da Paz, e Agostinho Alves Pinto, José Rabello, e outros que sendo pardos, e Agostinho preto, suas cinzas ainda hoje são respeitadas, e seus nomes com veneração lembrados; ora, dizei-nos: quem é Joaquim dos Santos, José Elesbão, Dornelles, Conceição, Teixeira, Brasil, e outros pardos que por suas virtudes e patriotismo se fazem dignos da estima e consideração de seus concidadãos? São pessoas que temamos? Não. Deixai portanto aos moderados a tarefa da intriga das cores, pois os que mais a atiçam são os que mais perto dela estão, e tratemos de unir-nos para fazer resistência constante aos moderados fingidos, que não são mais que colunas disfarçados" (BR, $\mathrm{n}^{\circ} 3,07 / 02 / 1832$, p. 15 - negrito adicionado).
} 
expediente político racista de enunciar, com autoridade conferida por sua própria posição discursiva, quais deveriam ser as posturas dos "pardos bons brasileiros". Assinala, ao fazê-lo, também as más condutas dos pardos, isto é, o Haitianismo.

Lembrem-se os Pardos, e Adotivos, que custa pouco intriga-los ao gosto dos futuros colonos Irlandeses do Conego Januario, chamando a uns haitianos, e a outros Lusitanos Restauradores de José Bonifácio. Lembrem-se os Pardos do que ouviram na discussão da intitulada Lei de serviços, e naturalização: lembrem-se os Pardos que nos promotores, e denunciantes das cantigas de Maio, do 14 de Julho, do 28 de Setembro, \&c. Havia muito Pardo, que se fingia medroso de haitianismo, e acusador de Barata como haitiano! Os Pardos bons Brasileiros, e liberais devem desconfiar muito de Pardo que finge ser branco, e dos Pardos que querem figurar, ou enriquecer: estes com os Restauradores d'Evaristo, e do Esbarra são os maiores inimigos do Brasil, e dos Pardos, que são bons Brasileiros, e Liberais, como são a maior parte destes nossos Patrícios. Pardo empertigado, ou dengue ora é haitiano, ora Evaristeiro, e sempre terrível inimigo dos bons Pardos aos quais ilude, vende com a mesma segurança com que furta o ladrão de casa. O Pardo bom Exaltado e Brasileiro Andradista deve sempre guiar-se pelo virtuoso patriota Barata, e fugir de Rusgas. ${ }^{194}$

É provável que se referisse à Joaquim Soares Cândido Meirelles quando menciona, de forma crítica, o "pardo que finge ser branco" e pretende "figurar" ou “enriquecer". Muitas vozes na época também o faziam e ele próprio admitia que seu nome estava ligado ao conceito. Meirelles era um famoso cirurgião e político da Corte, autoconsiderado "mulato". Chegou a ser médico pessoal do imperador. Em 1831 estava próximo dos Liberais Moderados, sendo um alvo dos Exaltados. Era visto com desconfiança por todos os lados: um "mulato" no mundo dos ricos, aristocratas e homens de Estado do Brasil pós-colonial desagradava a radicais e conservadores.

Nesta linha, o jornal $O$ Filho da Terra traz uma receita "contra o frenesi da Moderação" em que critica nominalmente a Meirelles e outros "pardos" em função de suas escolhas políticas. Novamente ensina-se aos não brancos como se comportar politicamente, repetindo as atitudes do Rusguentinho e do Aurora, vistas anteriormente. Após mencionar o "haitianismo e tudo quanto é péssimo", o jornal

\footnotetext{
${ }^{194} \mathrm{OR}, \mathrm{n}^{\circ}$ 4, 21/12/1833, p. 3-4 - negrito adicionado. O Rusguentinho vai adiante, na mesma edição, combinando nativismo e uma espécie de antirracismo que não questiona, contudo, a escravidão: "Um Brasileiro de pé no chão tem mais amor à Liberdade, e mais orgulho próprio de homem livre do que a maior parte dos Europeus de gravata lavada lá na Europa. Recordem-se do que aconteceu na rua do Ouvidor ao lindo Lord, Secretário de Lord Stuard. Cuidou o menino Lord que os Pardos no Brasil são tão destituídos de pundonor como os criados brancos na Europa, e tocou com um chicotinho num Pardo para lhe dizer que desse lugar ao seu carrinho; porém o Pardo Brasileiro caiulhe de cacete, e cabeçada com tanta gana, que o Lord ficou em lençóis de vinho e se não quis demorar na Terra dos Fluminenses" (OR, n 4, 21/12/1833, p. 8).
} 
acusa Meirelles de servir "de pau de cabeleira" para interesses alheios aos de sua etnia.

Recipe contra o frenesi da moderação - O Sr. Médico Joaquim Cândido, Cirurgião Jacinto, Padre Geraldo, \&c. usem de espelho e pente para verem, que são pardos, e não devem ser contra os seus patrícios Brasileiros nascidos no Brasil, visto que estes 3 Srs. estão servindo de paus de cabeleira para fortificar a facção Portuguesamoderada, que chama a todos os Brasileiros, quer brancos, quer pardos, de mulatos, e cabritos, o que nós somos, e não desonramos, e menos atraiçoamos os filhos da Terra. ${ }^{195}$

Variações dos mesmos temas circularam pelo mundo político brasileiro por anos. Em 1832, o periódico $O$ Exaltado, cujo titulo dispensa localizações no espectro político da época, vai descrevendo uma série de traições dos Moderados, que vão desde alianças com os Restauradores até práticas homicidas e aterrorizantes de sua milícia armada particular (as Guardas Municipais da Corte, pagas pelos “capitalistas" da sede imperial). ${ }^{196}$ O Haitianismo, neste caso, opera como dispositivo tático dos embates sobre que tipo de engenharia racial, ou "equilíbrio racial da população", seria desejável para o país, conforme já percebido por Carvalho (2014, p. 295). ${ }^{197}$ O jornal conclui que o Haitianismo é feito "para inculcar a necessidade de ficarem entre nós os brancos da Europa".

Sendo um debate sobre tecnologias de gestão e classificação racial de populações, tanto a colonialidade como o biopoder expressam-se, pois, neste tipo de discurso, que também apresenta Meirelles como "autor do Haitianismo":

(...) e processou o Sr. Major Miguel de Frias e Vasconcellos, Redator da Voz da Liberdade com testemunho de seu Compadre Meirelles, autor do Haitianismo, espalhado para meter medo aos Tolos; que comem araras; e lhes inculcar a necessidade de ficarem entre nós os brancos da Europa, para tirar casta branca com as nossas cabras, e fazer parede com os poucos brancos de cá v.g. Feijó, Evaristo, Saturnino, Januário, Geraldo, Teobaldo \&c. contra as nuvens negras, que possam descer dos picos do Itajurú... ${ }^{198}$

\footnotetext{
${ }^{195} \mathrm{FT}, \mathrm{n}^{\circ} 3,21 / 10 / 1831$, p. 8.

${ }^{196}$ Sobre as Guardas Municipais Permanentes, milícia paramilitar criada pelo governo de Liberais Moderados no início da Regência, ver Holloway (1997, p. 76-78). Este autor é simpático aos responsáveis por este desenvolvimento institucional paramilitar, em especial o ministro da Justiça à época, Diogo Antônio Feijó, que seria eleito regente posteriormente graças a sua reputação de ser capaz produzir controle do Estado e ordem. Vozes da época, no entanto, também acusam Feijó de autoritarismo, ao criar uma guarda pretoriana, subordinada diretamente à sua pasta, com a qual ameaçou e perseguiu ao próprio parlamento imperial e opositores políticos em episódios diversos. 197 José Murilo de Carvalho sugere uma equivalência semântica entre "equilíbrio racial", "guerra das raças" e "haitianismo" (2014, p. 295).

${ }^{198} \mathrm{OE}, \mathrm{n}^{\circ} 17,16 / 01 / 1832$ p. 4 - negrito adicionado.
} 
Por fim, o Pão D’Assucar também entra frontalmente na questão racial, enfatizando sua importância para as posições políticas adotadas. Em pelo menos duas oportunidades a forma de articular seu racismo aparece junto com o Haitianismo ou referências ao Haiti. Na primeira delas o argumento pressupõe que a "pátria" possui "cor", algo que, se esquecido, levaria à "catástrofe".

É já tempo de parar no vórtice obstinado de perseguições. Moderação insensata! voltai a vossa razão. Dizei-nos, moderados, pretendeis debelar o haitianismo, e buscais dilacerar os da vossa cor? É isto compatível com os meios de defesa para uma tal crise? Homens inconsequentes e cruéis, cessai um dia de mortificar a desgraçada Pátria, quase exangue por vossa causa. Vede que vós não escapareis à catástrofe: tremei por vós mesmos. ${ }^{199}$

A segunda ocasião é ainda mais instigante e reveladora da colonialidade, pois o racismo alcança seu paroxismo nesta argumentação que, surpreendentemente, termina sendo elogiosa ao Haiti. Aqui a palavra Haitiano não é usada de maneira pejorativa. A preocupação do autor é com a criação de "um sistema de homens de sua cor", em qualquer lugar, seja no Brasil ou no Haiti. O importante é a divisão racial entre as nações. O motivo seria a "segurança e prosperidade" da sociedade branca, que ele teme estejam sob ameaça no Brasil após a Revolta dos Malês, em 1835, nas imediações de Salvador, Bahia. Mesmo que na última frase o argumento não seja confirmado (recorrendo ao discurso sobre a especificidade brasileira no manejo racial), seu desenvolvimento não deixa dúvidas quanto à utopia biopolítica internacional do autor em produzir espaços políticos e jurídicos racial e nitidamente demarcados.

Os conselhos, que o amor da nossa Pátria nos inspira para tão afoitamente dá-los aos nossos Concidadãos, se fundam em verdades de tal intuição, que não escaparam aos pretos da ilha do Haiti, que pretendendo consolidar um sistema de homens de sua cor, determinaram que um dos artigos do seu Código Constitucional, que nenhum branco de qualquer Nação, que fosse, que pisasse o seu território, poderia ser Proprietário, nem Cidadão; permitindo ao mesmo tempo, que os Africanos ou os que procedessem de seu sangue, quer nascidos nas Colônias, quer em países estrangeiros, fossem reconhecidos Haitianos, e depois de um ano de residência gozassem dos Direitos de Cidadão; e cumpre mais notar que nesta República todo o Cidadão, quer seja nascido no próprio país, quer fora dele, pode pretender todos os cargos, ainda o de Supremo Chefe da Mesma República: é de espantar, que homens apenas saídos da escravidão doméstica fossem tão despidos de preocupações, e conhecessem também os seus interesses para abraçarem uma política tão acomodada à sua situação, quando nós que não temos saído de um estado tão abjeto, estamos tão preocupados com ideias pouco análogas à nossa segurança e prosperidade. Contudo, não alegamos este exemplo

${ }^{199} \mathrm{PA}, \mathrm{n}^{\mathrm{o}} 27,07 / 04 / 1835$, p. 3 - negrito adicionado. 
para que absolutamente o imitemos no nosso oposto sistema, excluindo aqueles, que por serem de diferente cor, nem por isso devemos deixar de admiti-los iguais direitos. ${ }^{200}$

\section{Considerações finais}

Neste capítulo, pôde-se observar as maneiras em que o termo Haitianismo foi textualmente mobilizado no contexto discursivo do Período Regencial (18311840) do Império Brasileiro. Época marcada por lutas políticas que envolveram o Haitianismo tanto nos embates eleitorais quanto em denúncias de perseguição política, encarceramento e até assassinato de adversários, tratados como "inimigos do Brasil" por quem empregava este expediente retórico. A palavra foi usada como sinônimo de crimes, principalmente o de Insurreição. E também esteve presente nos discursos sobre segurança pública que pediam mais investimentos nas forças policiais, controle e vigilância estatais. O Haitianismo chegou a ser indicado como motivo das suspensões de direitos constitucionais no Brasil imperial. Estava nas capas e manchetes dos jornais, em editoriais, colunas sobre conjuntura política e até em seções de humor.

Forças de ambos os extremos do espectro político acusavam o centro de promover uma cruzada contra seus adversários para consolidar seu poder no novo regime. A resposta vinha no mesmo nível, atiçando intrigas pessoais e políticas, em meio a ofensas de cunho racista, dentro de um mundo político predominantemente branco e proprietário. O Haitianismo também fez parte, como era de se esperar, em debates que tratavam diretamente da questão racial no Brasil pós-colonial, fosse como parte das batalhas discursivas sobre "intrigas de cores" e "guerras de raças", que versavam sobre tecnologias de engenharia racial, ou até mesmo como embasamento para discursos embrionários sobre uma suposta democracia racial no Brasil escravista.

Uma listagem de efeitos de poder cujas marcas se ligam com este tipo de discurso incluiria:

a) supressão ou redução de direitos civis e políticos;

b) violência e controle de corpos racializados como não brancos;

c) autorização para gastos com militarização da "segurança pública";

d) definição de traição e lealdade à ordem: desqualificação política da diferença/oposição;

${ }^{200} \mathrm{PA}, \mathrm{n}^{\mathrm{o}} 27,07 / 04 / 1835$, p. 4 - negrito adicionado. 
e) intrigas eleitorais e ministeriais, disputa por cargos na máquina estatal;

f) argumentos sobre identidade racial do país e conduta política de não brancos.

Ao contrário dos usos discursivos do Haiti vistos no capítulo anterior, aqui as narrativas não se dão em termos de "repercussões" ou "reflexos" da Revolução Haitiana no Brasil, enunciada a partir do binômio repetição/rejeição. Um olhar mais detido sobre o conceito e os jogos de linguagem em que estava envolvido mostrou que, quando que se trata do universo discursivo do Haitianismo stricto sensu, são as agendas políticas locais e cotidianas que prevaleceram. Nem tanto influência direta do Haiti, portanto, mas uma apropriação antropofágica, pelo imaginário branco brasileiro, sobre a Revolução Haitiana para usos inovadores no debate político da Era Regencial.

A partir de 1831, quando aparece no léxico político, o Haitianismo torna-se um dispositivo de linguagem que, apesar de polissêmico e utilizado por diferentes vozes do espectro partidário, designa, de modo geral, uma "traição" por parte de alguma força ou agente político. Indica o rompimento de uma espécie de pacto tácito acerca da não instrumentalização de escravizados para fins políticos imediatos, fosse por meio de golpes e sedições militares na Corte, ou meramente via o aproveitamento eleitoral que simples rumores neste sentido podiam proporcionar. Versava, portanto, sobre a disputa pelo exercício do poder, em paralelo à necessidade comum de expandir o aparato de segurança estatal para manter o controle sobre os escravizados e seus possíveis aliados, negros "livres" ou mesmo brancos radicais, chamados de "anarquistas". Os problemas da colonialidade do poder e da biopolítica estavam, portanto, no cerne da questão.

Mais do que o estalido de uma Revolução nos moldes da Haitiana em território brasileiro, o Haitianismo serviria, então, para designar aqueles traidores da pátria que ousam romper, discursiva ou conspirativamente, os limites sociorraciais da vida política. Se os escravizados são os inimigos internos, como se dizia, o adversário político que os alicia para fins egoístas deve ser tratado como traidor. Em momento de desunião entre as elites, tal recordação esteve em voga. Seu uso constante produziu o Haiti, ou o Haitiano, como alteridade constitutiva da identidade brasileira, do "bom brasileiro". É neste sentido, então, que se deve compreender as afirmações taxativas de Schwarcz e Sterling (2015) a respeito do 
tema, quando afirmaram: "O Brasil se inventou, assim, como um anti-Haiti: por oposição éramos todos brancos, cristãos e civilizados" (2015, p. 229).

O Haitiano é, portanto, o Outro no mundo político branco do nascente Brasil pós-colonial. Até os Liberais Exaltados repetiram este expediente em diversas ocasiões, mostrando que seu discurso compartilhava das mesmas contradições do restante do Liberalismo escravista brasileiro. Mesmo essa força política mais radical também se julgava autorizada a ensinar o que os "pardos" e "pretos" deveriam fazer politicamente, dizer quais líderes deveriam seguir e por quê. Dentre as razões apontadas, para não ser confundido com Haitiano ou acusado de Haitianismo.

Assim, esta operação discursiva representava aos adversários de uma forma que tornava justificável sua perseguição, controle e até extermínio. Trata-se do biopoder em sua forma mais drástica, implicando literalmente o poder sobre a vida ou o fim dela. No Brasil pós-colonial, era sobre os corpos negros que esta operação gerava efeitos de poder mais violentos e concretos, como nas situações de punições físicas em quantidade inimagináveis denunciadas pela imprensa Liberal Exaltada. Ou nas execuções sumárias em nome do Haitianismo denunciadas até no Parlamento, como visto na fala do deputado Joaquim Candido Meirelles, acusado ele mesmo de Haitianismo. Neste momento, o poder do Haitianismo brasileiro revela toda sua colonialidade, ao por em prática uma classificação social baseada na ideia de raça que distinguia aqueles que estavam preocupados com diminuições de direitos e difamações (como Meirelles e o redator do Pão D'Assucar), de um lado e, de outro, aqueles cuja preocupação era a perda da própria vida ou a integridade de seus corpos (como o Bacorinho).

Cumpre notar que o uso deste expediente discursivo na imprensa política imperial diminui bastante após 1835 ou 1836. A partir da análise da documentação, ganha força a tese de Flory (1977), sobre este ponto. ${ }^{201} \mathrm{O}$ historiador sugere que a Revolta dos Malês, em 1835, foi responsável pela mudança de postura das elites políticas brasileiras quanto à racialização explícita e agressiva dos embates políticos locais e nacionais. Para ele, após um ápice de racialização, quando o Haitianismo

\footnotetext{
201 Outros fatores certamente contribuíram para este desuso repentino do Haitianismo e a especulação sobre este ocaso foge aos objetivos desta pesquisa. No entanto, cabe notar que a segunda metade da década experimenta arrefecimento (ou derrota) gradativo dos conflitos e revoltas liberais, ao passo que crescia a recomposição das forças conservadoras que levariam ao Regresso a partir da década de 1840 (CARVALHO, 2014; SALLES, 2012).
} 
foi usado com muita intensidade, teria havido uma mudança radical nesta tendência, em direção a uma tentativa de desracializar o debate político brasileiro e construir um discurso sobre igualdade jurídica racial, dentre outras práticas negacionistas do racismo Brasileiro.

Assim como seria feito em 1936 por Gilberto Freyre (2004) um século depois, neste argumento já difundido em 1835 o Haiti era novamente o Outro, descrito como um lugar que não possuía as mesmas vantagens tecnológicas que o Brasil na gestão racial da vida social e política. Tal inflexão, parece ter tido um efeito importante na genealogia do Haitianismo, que passou de provocação racista aberta, como no Mutuca Picante, para base da defesa de uma embrionária democracia racial no Brasil escravista, feita pelo Aurora Fluminense e outros.

Um traço distintivo próprio da colonialidade particular do nascente Brasil pós-colonial parece ser que a defesa da democracia racial tinha como argumento a própria colonização, no caso a portuguesa, e suas peculiaridades: mais doçura, igualdade de condições jurídicas, nobreza não branca etc. Nessas condições discursivas, não surpreende encontrar tais vozes dizendo aos "pretos" e "pardos" como agir politicamente e ser socialmente, trazendo à tona o problema representacional descrito por Spivak (1988). O Haitianismo participa, assim, tanto dos mitos de agressividade e violência da população negra no Brasil, que precisa ser vigiada e contida; quanto seu inverso, os discursos da miscigenação, democracia racial, passividade, cordialidade (ANDREWS, 1997; CARDOSO, 2008).

Fala-se, ademais, em "humanidade" neste universo discursivo do Haitianismo, que também é permeado de apelos à razão, ao Liberalismo e referências à Revolução Francesa. Pede-se trato mais humano para com os castigados e apela-se a interesses narrados como universais, como a manutenção da ordem, frente a ameaças que precisam ser externalizadas e estrangeirizadas, como feito no caso do conceito de Haitianismo, para designar atentados subversivos impensáveis e inaceitáveis no jogo político interno e local. Todas as forças políticas pedem paz e criticam a guerra entre as províncias, entre as classes e "castas", ao passo que reproduzem interações conflituosas em todas essas três dimensões.

No próximo capítulo, serão analisados novos discursos brasileiros que versam sobre o Haiti, a paz, a defesa da humanidade e de princípios tidos como universais, em grande parte vinculados a inspirações políticas e filosóficas Liberais também. Mas agora, no século XXI, no contexto da participação brasileira na 
MINUSTAH, não se fala mais em Haitianismo, haitianar, haitianada, como visto neste capítulo sobre as fontes primárias do século XIX.

Hoje, o haitiano, ou haitiana, continua sendo objeto de alteridade no discurso político e internacional brasileiro. Segue sendo narrado como fonte de ameaça e, ao mesmo tempo, como objeto necessitado de cuidado e controle biopolítico. O tema racial e a colonialidade aparecem na forma de distinções culturais, comentários em que se evoca hierarquias civilizacionais e narrativas de modernização. Nestes discursos, encontra-se contraposições discursivas binárias que opõem Brasil e Haiti, o moderno e o arcaico, de maneira logocêntrica, e que podem ser observadas até mesmo nas vozes que praticam uma crítica da intervenção humanitária na ilha caribenha (SABARATNAM, 2013).

São discursos que se pretende descolonizar a partir da contribuição que o estudo do Haitianismo, com sorte, pode proporcionar para a releitura (hiper)crítica das atuais agendas e embates políticos que envolvem a mobilização discursiva do Haiti ocupado por tropos, tropas e agências internacionais no século XXI. 


\section{CAPÍTULO 5: MINUSTAH: colonialidade e biopoder em ação no Haiti}

\section{Origem da intervenção}

Em 29 de Fevereiro de 2004, o Conselho de Segurança das Nações Unidas (CSNU) aprovou a resolução $\mathrm{n}^{\circ} 1529$, autorizando o emprego de uma Força Interina Multinacional por um período de três meses no Haiti. No mesmo dia, o presidente norte-americano, George W. Bush, declarava à imprensa nos jardins da Casa Branca que estava enviado fuzileiros navais dos EUA para trazer ordem e estabilidade para o Haiti, como a parte principal desta Força. No documento do CSNU, são listados onze itens que, invocando o Capítulo VII da Carta da ONU, descreviam a natureza daquela intervenção multilateral provisória ${ }^{202}$.

O preâmbulo da resolução apresenta as razões que motivaram a intervenção. A situação no Haiti é descrita como "constituindo uma ameaça à paz e segurança internacionais", assim como à "estabilidade do Caribe", especialmente devido "ao potencial fluxo de pessoas em direção a outros Estados na sub-região". O curto texto fala três vezes em “deterioração da situação humanitária no Haiti”, deplorando as "perdas de vidas que já aconteceram" e expressando preocupação com a "violência continuada" no país. Define como uma necessidade a criação de um “ambiente de segurança no Haiti e na região" para garantir o respeito aos direitos humanos, "incluindo o bem-estar de civis", além de apoiar o trabalho de "missões humanitárias". 203

O documento foi aprovado horas após a partida para o exílio do presidente haitiano Jean Bertrand Aristide, designada como "renúncia" pelo texto do CSNU, mas negada pelo mandatário deposto, que afirma ter sido raptado e colocado contra sua vontade em uma aeronave militar dos Estados Unidos ${ }^{204}$. O último item da

202 Para o texto completo da resolução, ver (acesso em Junho/2018): https://www.securitycouncilreport.org/atf/cf/\%7b65BFCF9B-6D27-4E9C-8CD3CF6E4FF96FF9\%7d/Chap\%20VII\%20SRES\%201529.pdf.

${ }^{203}$ CSNU, resolução $\mathrm{n}^{\circ} 1.529$, p. 1 .

${ }^{204}$ Para uma análise das remoções de Aristide em 1991 e 2004, ver Hallward (2004, p. 7), que entende os casos a partir da comparação entre o presidente duas vezes deposto e o revolucionário Jean-Jacques Dessalines, líder da independência haitiana. Sobre as controvérsias envolvendo a deposição ou renúncia de Aristide e a conseqüente polêmica sobre a legalidade da MINUSTAH, ver o capítulo III da obra de Seitenfus (2016). Para uma investigação, publicada pelo jornal Haïti Liberté, que revela correspondência diplomática secreta dos EUA (vazada pelo wikileaks) nas quais admite-se participação na derrubada e exílio forçado de Aristide, considerado um risco para os interesses norte-americanos e para as políticas pró-mercado no Haiti, ver Herz e Ives (2011), 
resolução convida a Comunidade Internacional a "trabalhar com o povo do Haiti em um esforço de longo prazo para reconstruir as instituições democráticas do país", ajudando na formulação "de uma estratégia que promova desenvolvimento econômico e combata a pobreza". ${ }^{205}$ Além de exortar os Estados-membros da ONU a contribuir com pessoal, equipamentos e recursos financeiros, esta resolução já informa que o CSNU está pronto para estabelecer uma nova missão no prazo máximo de três meses. A nova missão, chamada de "estabilização", deverá substituir esta interina e ajudar na "continuação do processo político pacífico e constitucional” e na "manutenção da segurança e de um ambiente estável”, 206

Assim sendo, em 30 de abril do mesmo ano, o CSNU aprovaria nova resolução sobre o Haiti, $\mathrm{n}^{\circ}$ 1542, desta vez criando a Missão das Nações Unidas para Estabilização do Haiti (MINUSTAH), por um "período inicial de seis meses"207. A nova força seria composta por 6.700 soldados e 1.622 policiais, além de pessoal civil, local e estrangeiro. Segundo o comunicado de imprensa da ONU, a reunião do CNSU que aprovou a criação da MINUSTAH durou apenas três minutos, das 12:34 às 12:37, ilustrativa da unanimidade em sua aprovação. O texto remete à resolução anterior e informa como razões da continuidade e aprofundamento da intervenção a "existência de desafios à estabilidade política, social e econômica do Haiti”. E o faz invocando o Capítulo VII, uma vez que o Haiti segue tratado como "ameaça à paz e à segurança internacional na região" 208 .

Ainda que posteriormente reconheça-se que o Haiti não estava em guerra civil, a linguagem da resolução insere firmemente a missão no intervencionismo multilateral do pós-Guerra Fria, reafirmando o tradicional jargão de Desarmamento, Desmobilização e Reintegração (DDR), e a democratização, como principais objetivos da missão da ONU. São três grupos de metas específicas a

disponível em (acesso em Agosto de 2018): https://www.thenation.com/article/wikileaks-haitiaristide-files/. Para uma compilação de versões conflitantes, dois dias após a mudança de regime, ver reportagem da rede norte-americana $\mathrm{CNN}$, que traz denúncias, dentre outros, de congressistas dos EUA contra o que chamaram de "golpe" no Haiti e o suposto envolvimento do Sub-Secretário de Estado para América Latina à época, Roger Noriega, em tais eventos, disponível em (Acesso em Agosto 2018): http://edition.cnn.com/2004/WORLD/americas/03/01/aristide.claim/.

${ }^{205}$ CSNU, resolução $\mathrm{n}^{\circ} 1.529$, p. 3.

${ }^{206}$ CSNU, resolução $n^{\circ} 1.529$, p. 2.

${ }^{207}$ CSNU, resolução n ${ }^{\circ} 1.542$, p. 1. Para o texto completo da resolução, ver (acesso em Junho 2018): https://www.securitycouncilreport.org/atf/cf/\%7b65BFCF9B-6D27-4E9C-8CD3-

CF6E4FF96FF9\%7d/CAC\%20SRES\%201542.pdf. A MINUSTAH mantém uma página oficial na internet, em francês. Ver (acesso Setembro 2018): https://minustah.unmissions.org/.

${ }^{208}$ CSNU, resolução $n^{\circ} 1.542$, p. 1 . 
serem alcançadas pela MINUSTAH: (i) um "ambiente seguro e estável", que enfatiza a reforma do aparato policial haitiano; (ii) "processo político", que pretende realizar novas eleições sob supervisão internacional; e (iii) "direitos humanos", que possui um tom mais intimidador, prometendo "por fim à impunidade", destacando abusos de direitos de mulheres e crianças. No entanto, fala-se em colaboração com o governo interino, já depurado do partido político Fanmi Lavalas e da sua liderança, Aristide, mantido no exílio. ${ }^{209}$

No comunicado de imprensa da ONU sobre a resolução há um anexo intitulado "background", que procura situar o contexto no qual a decisão por aprofundar a intervenção estava sendo tomada. ${ }^{210}$ Nele afirma-se que o Haiti estaria preso a um "ciclo de violência e impunidade". E termina com declarações que contrariam a resolução anterior (que falava em renúncia) ao alegar que o presidente Aristide foi "forçado a deixar seu país em 29 de Fevereiro devido à insurgência armada". Mesmo com esta asserção, o anexo exorta o partido do presidente deposto, Fanmi Lavalas, a participar do processo de transição política e lamenta sua "notável exceção"211 nas assinaturas de um documento sobre consensos possíveis, firmado pelas demais forças políticas haitianas (que faziam oposição à Aristide). Em nenhum momento faz menção à restauração do mandato do presidente deposto como parte dos objetivos de restabelecimento da ordem e da democracia no país. ${ }^{212}$

\section{O discurso brasileiro sobre o sucesso da MINUSTAH}

As narrativas brasileiras sobre o Haiti no âmbito da MINUSTAH partilham, em grande medida, da linguagem própria à paz liberal encontrável nos documentos das Nações Unidas, como estes acima, dentre outros meios de difusão vistos no capítulo 2. Apresentam, contudo, fatores distintivos importantes na articulação de seus argumentos, invocando repetidas vezes aquilo que é descrito como laços de

\footnotetext{
${ }^{209}$ CNSU, resolução n ${ }^{\circ} 1.542$, p. 2-3.

${ }^{210}$ Para o comunicado de imprensa oficial da ONU, ver (acesso em julho de 2018): https://www.un.org/press/en/2004/sc8083.doc.htm.

${ }^{211}$ CNSU, resolução $n^{\circ} 1.542$, p. 3.

${ }^{212}$ Em 1993/94, a missão conjunta da ONU e da OEA no Haiti buscava evitar abusos de direitos humanos promovidos pela junta militar liderada por Raoul Cedras, general que havia deposto o mesmo Aristide, eleito presidente em 1991 após quatro décadas de ditadura duvalierista. Diferentemente do acontecido sob a MINUSTAH, naquele momento a restauração do mandato constitucional de Aristide era um objetivo declarado da Comunidade Internacional. Nos anos 1990, o retorno à legalidade e do presidente deposto foram conseguidos mediante intervenção armada norte-americana, propiciando que Aristide terminasse (os poucos meses restantes) de seu mandato e fizesse uma transição de poder pacífica e constitucional para o presidente eleito René Preval, até então seu aliado político. Ver: Câmara (1998) e Seitenfus (2016).
} 
identidade entre Brasil e Haiti (ou brasileiros e haitianos), mesmo que afirmem, concomitantemente, a diferença entre os dois entes discursivos, deixando nítida a hierarquia entre ambos. Ambas, identidade e diferença, são mediadas por construtos raciais. Tornam-se compreensíveis, por isto, por meio de abordagens como a de Roxanne Doty (1993) que situa a "raça" nos debates teóricos de RI como um "lugar onde foram constituídas fronteiras" a partir de "entendimentos particulares de identidade e diferença" (DOTY, 1993, p. 449). ${ }^{213}$

Este "hibridismo" (MORENO et al., 2012, p. 388), no qual o Brasil é - e ao mesmo tempo não é - semelhante ao Haiti, traduz-se, em tais apreciações, em uma melhor tecnologia de gestão daquele tipo de missão, como será visto nas páginas que se seguem. Tal habilidade seria fruto de um maior conhecimento, uma experiência acumulada e, sobretudo, uma sensibilidade mais adequada, capaz de negociações e improvisos, que os pacificadores brasileiros carregariam para a tarefa de estabilizar territórios-alvo cuja população - conforme alertado por vozes críticas - é identificada por traços bem delineados neste regime discursivo: pobres, negras e perigosas (BORBA DE SÁ et al., 2017).

Tal jogo de linguagem entre identidade e diferença é sistematizado por um estudioso da MINUSTAH que, após evocar a "matriz cultural africana em comum", apresenta os contornos desta tese sobre a maior capacidade brasileira de encontrar uma "solução" para o Haiti justamente a partir desta aparente "contradição" identitária (SOUZA NETO, 2012, p. 245).

Apesar do próprio Brasil enfrentar uma série de problemas sociais e de segurança semelhantes, embora em menor grau, à realidade haitiana, há um grande potencial na contribuição brasileira à reconstrução haitiana. A experiência brasileira no Haiti mostra que essa condição do Brasil não se constitui em contradição, mas sim permite que o país articule uma solução própria à crise haitiana, proporcionando uma cooperação equilibrada e com base em soluções conjuntas aos problemas que afetam a ambos os países. (SOUZA NETO, 2012, p. 249)

Não apenas na academia brasileira, mas em declarações, documentos e entrevistas de autoridades estatais (incluindo militares e diplomatas) e no âmbito das ONGs que trabalham em conjunto com as forças de pacificação do Brasil é

\footnotetext{
${ }^{213}$ Para uma introdução ao debate crítico sobre o tema da "raça" nas teorias de RI, feito por autores que recorrem à argumentos pós-coloniais ver, além de Doty (1993), Grovogui (2006), Krishna (2006), Persaud (2002) e Vitalis (2000). Este último dedica uma seção à discussão sobre "Normas Humanitárias e Racismo", na qual esboça uma crítica intra-construtivista aos colegas entusiastas das intervenções da paz liberal, especialmente Martha Finnemore [1996] (Vitalis, 2000, p. 336-342). Para uma abordagem decolonial sobre o tema da raça, ver Quijano $(2000 ; 2005)$.
} 
frequente este tipo de postura favorável ao "jeito brasileiro", ou "modelo brasileiro", de praticar operações de manutenção de paz (ABDENUR; CALL, 2017; BRAGA, 2017; CARVALHO, 2017; CLAUHS, 2013; KENKEL, 2011, p. 28-30; VIEIRA NETO, 2017). Todos convergem no sentido de concluir que "sem sombra de dúvida, o Brasil no Haiti é um caso de sucesso" (MENDONÇA, 2017, p. 65 negrito no original).

Tal literatura sustenta que "traços culturais" em comum transformam-se em “capacidades" aumentadas, que garantem maior eficácia para "estabilizar" locais como o Haiti: a pacificação brasileira seria "mais humana, progressista e responsável” (KALIL; NAPOLEÃO, 2015, p. 90; 109). Os militares do Brasil teriam uma "relação de confiança e contato direto com a população local", mostrando "humildade", sem "intimidação", estimulando o "contato com lideranças comunitárias civis da região" e "promovendo também atividades esportivas e culturais" (SOUZA NETO, 2012, p. 250-252). Defende-se que o "soft power brasileiro" é resultado da "proximidade cultural e a identificação que muitas vezes ocorre entre o povo haitiano e os 'capacetes azuis' brasileiros", levando à maior eficiência "ao utilizar-se da influência cultural para assegurar o cumprimento das metas da MINUSTAH” (VIANA, 2009, p. 32-34; KAWAGUTI, 2006). Há quem diga que o soldado brasileiro "é criativo e bem-humorado", capaz de desempenhar um "exercício de diplomacia cultural: ele reforça laços de camaradagem, ele reafirma um soft power sem pretensões impositivas, ele facilita o diálogo e a compreensão (CARVALHO, 2017, p. 48).

Ademais, argumenta-se que a participação do Brasil ajuda a aperfeiçoar as intervenções da paz liberal, na medida em que sua presença contrabalançaria a dominação das potências ocidentais, desenvolveria conhecimentos novos para o debate sobre segurança global (como os princípios de Responsabilidade Ao Proteger e da Não Indiferença), além de reforçar o elo entre segurança e desenvolvimento (ABDENUR; HAMANN, 2017; CEZNE; HAMANN, 2016; KENKEL, 2011; NASSER, 2012). Neste sentido, "as características e as representações simbólicas da presença brasileira se traduziriam por um comportamento mais ameno", fundamental para o "êxito da missão" (VALLER FILHO, 2007, p. 171). E tal combinação entre uso moderado da força, foco no desenvolvimento econômico e exportação de políticas sociais bem-sucedidas 
domesticamente fariam do "modelo brasileiro de pacificação" exportável para além do Haiti (KENKEL, 2011, p. 28-30).

Nesta linha, houve que defendesse o papel do Brasil na MINUSTAH como exemplo das benesses de um novo modelo de "ingerência solidária" (SEITENFUS, 2006, p. 7), “diplomacia solidária” (LULA DA SILVA, 2014) ou “cooperação sustentável" entre países do Sul global (HIRST, 2012, p. 20). A missão teria sido um exemplo de como o Brasil usa a cooperação técnica como instrumento de solidariedade (VALLER FILHO, 2007) e seria indicativa dos "avanços" vinculados com a "presença latino-americana, na qual se destacava a atuação do Brasil", marcada pela “diferenciação" frente aos outros atores da Comunidade Internacional presentes no Haiti (HIRST, 2012, p. 20-23). De fato, tornou-se um lugar comum afirmar que "o envolvimento brasileiro merece destaque por adotar uma postura diferente" (SOUZA NETO, 2012, p. 259). Chegou-se ao ponto de propor que o chamado modelo brasileiro de pacificação poderia ser chamado de "Pax Brasiliensis", dada sua singularidade e capacidade de colocar a "solidariedade" e o "humanismo" como interesses nacionais da política externa brasileira (NASSER, 2012, p. 213).

Nunca se deixa de ressaltar "afinidades de natureza cultural e étnica" (AMORIM, 2006, p. 2) entre Brasil e Haiti, como facilitadoras da missão. Cumpre notar que tais enunciados foram repetidos por amplo leque de vozes, mas sua origem está nas formulações oficiais do próprio governo brasileiro. Celso Amorim, ministro das Relações Exteriores e posteriormente da Defesa durante a MINUSTAH, mencionava que os brasileiros sempre agiram com "humildade e respeito aos haitianos" (AMORIM, 2010, p. 53). Por sua vez, o então presidente Lula da Silva foi provavelmente aquele que mais enfaticamente defendeu essa distinção da atuação brasileira. Em discurso durante a cerimônia de formatura de tropas brasileiras na capital haitiana, o mandatário salientava:

A Minustah vinha dando um exemplo extraordinário de como é possível garantir segurança sem esquecer as aspirações ao bem-estar e à dignidade deste povo. As tropas brasileiras são universalmente reconhecidas por sua capacidade de estabelecer laços de confiança e solidariedade seja onde estiverem. Seu êxito em levar paz e tranquilidade aos bairros pobres de Porto Príncipe é reconhecido, admirado e copiado. (LULA DA SILVA, 2010, p. 83)

Em outra oportunidade, ao discursar na Base Aérea de Brasília durante a cerimônia de honras fúnebres aos militares mortos no terremoto que assolou o Haiti 
em 2010, o então presidente elaborava ainda mais esta narrativa, acrescentando-lhe contornos explicitamente raciais, em meio a uma dramática exaltação deste modelo brasileiro:

\begin{abstract}
A tragédia que se abateu sobre o Haiti, no dia 12 de janeiro de 2010, foi um desses episódios em que o destino cego e implacável parece ter assumido as rédeas da condição humana. Nosso coração, que já estava partido pelo sofrimento desse povo-irmão, de raízes africanas como as nossas, recobriu-se duplamente de luto e dor nos dias que se seguiram (...). Estou falando de destemidos compatriotas que chegaram ao Haiti levando a seguinte mensagem àquela gente sofrida: "Vocês não estão sozinhos. Viemos aqui em nome do Brasil. Trazemos segurança para suas famílias, trazemos paz. Trazemos remédios, solidariedade e, acima de tudo, o respeito do povo brasileiro ao povo haitiano". Cada um desses homens reafirmou, durante sua vida, a vocação pacífica e solidária da nação brasileira. Sem nunca perder a firmeza e a coragem necessárias para combater a violência e a criminalidade que tanto assolavam o Haiti, nossos militares sempre souberam conviver harmoniosamente com a população local, e ganhar a sua estima. O soldado brasileiro nunca foi confundido com invasores estrangeiros. Muito pelo contrário: foi a sua mão amiga que criou a confiança mútua entre a Força de Paz das Nações Unidas e os justos anseios da sociedade haitiana. (LULA DA SILVA, 2010, p. 51)
\end{abstract}

As revistas de ciências militares brasileiras igualmente produziram versões deste mesmo argumento. Vozes e saberes das Forças Armadas são um componente indispensável na análise da discursividade em torno das particularidades que tornariam o Brasil melhor preparado para exercer biopoder sobre a população haitiana por causa de sua própria condição pós-colonial. Um tenente-coronel do Exército, por exemplo, ao apresentar sua pesquisa sobre o Trabalho Emocional [TE] dos combatentes em Missões de Paz, sustenta que:

A empatia do povo brasileiro, conhecida e cantada por muitos, favorece o sucesso no TE. É possível verificar que esse aspecto é percebido, geralmente, como um ponto que faz a diferença na missão, quando comparado com o trabalho de militares de outros países. (COSTA, 2013, p. 142-143) $)^{214}$

Não escapa aos militares, tampouco, formular tal argumento de maneira explicitamente racial, como no estudo de um membro da Escola de Comando e

\footnotetext{
${ }^{214}$ Há quem acrescente, neste ponto, uma maior adaptabilidade psíquica dos militares brasileiros a cenários como o Haiti, atestada inclusive por exames médicos: "Estudo recente da Fundação Oswaldo Cruz, da Universidade Federal do Rio de Janeiro e das Forças Armadas identificou que os militares brasileiros tendem a desenvolver pouco estresse pós-traumático no Haiti, pela familiaridade com situações de pobreza e miséria, semelhantes à realidade brasileira. Foi constatado ainda que os militares brasileiros desenvolvem menos o hormônio do estresse do que tropas de países desenvolvidos e que os soldados envolvidos em atividades de cunho humanitário conseguiam desenvolver o hormônio DHEA, considerado um hormônio antiestresse" (SOUZA NETO, 2012, p. 255).
} 
Estado-Maior do Exército (ECEME). Ele parte do "pressuposto de que da formação multiétnica do povo brasileiro sobressaem-se peculiaridades que, permeando o imaginário coletivo, facilitam o exercício da liderança em ambientes interculturais" (CLAUHS, 2013, p. 100). Recorrendo a obras de sociologia e antropologia cultural brasileira, notadamente às teses de Gilberto Freyre, Sérgio Buarque de Holanda, Renato Ortiz e Roberto da Matta, o autor desenvolve um argumento ancorado nas noções de "miscigenação", "miscibilidade étnica", "mistura de cores de peles", "hibridização da cultura", "plasticidade social", "fusão cultural", "solidariedade multiétnica ou multicultural" com as quais busca expressar sua tese sobre a vantagem brasileira, ou "jeitinho brasileiro", para liderar determinado tipo de missão, dada a "inteligência cultural” da "gente brasílica” (2013, p. 107-108).

Ele conclui que "assim, é possível inferir que, em meio a esse triangulo social das etnias, o ambíguo, o híbrido, passaram a ser reinterpretados como dados positivos da mestiçagem; uma síntese do melhor que pode existir no negro, no branco, no índio" (CLAUHS, 2013, p. 102). Um dos "discursos de sujeito coletivo" que o autor identifica em sua pesquisa "qualiquantitativa" com colegas de farda que participaram de missões de paz no exterior é formulado da seguinte forma:

\begin{abstract}
O brasileiro, ele tem facilidade em aceitar diferenças culturais. Isso, acho que fruto da característica de formação do nosso povo, onde a gente lida com a diversidade no dia a dia [...]. O brasileiro ele tem bastante facilidade, porque nós não temos preconceitos, por essa quantidade de raças, esse relacionamento que a gente tem, a falta de preconceitos que o Brasil sofre, então pra gente negro é igual índio, então isso contribui diretamente pra essa nossa flexibilidade e o jeito de ser do brasileiro, que é amigo, que respeita todo mundo [...] É porque o militar brasileiro ele se destaca em termos de humanidade, pelas suas características humanas. (CLAUHS, 2013, p. 106)
\end{abstract}

De fato, as formulações dos militares tendem a destacar esta linha argumentativa. Para o general Floriano Peixoto Viera Neto (2017), que foi comandante da MINUSTAH entre 2009 e 2010, "há uma vocação multifuncional do soldado brasileiro", que resulta em "uma verdade absoluta: O Brasil responde de forma excepcional aos chamamentos das operações de paz” (2017, p. 20-21). Já o contra-almirante Carlos Chagas Vianna Braga (2017) conclui que "o sucesso alcançado pelo Brasil pode ser atribuído a (...) uma indiscutível capacidade de adaptação para superar os grandes desafios que foram apresentados" (2017, p. 42). Em artigo recente no qual explica as "razões do sucesso da missão no Haiti", o coronel Marcos Mendonça (2017) reitera a suposta "característica marcante da 
personalidade do soldado brasileiro (mais afável e flexível que de outros países)". Ele destaca como principal, dentre as 21 causas apontadas, em primeiro lugar, "a forte identificação étnico-racial” (2017, p. 61) entre brasileiros e haitianos.

[A] descendência africana do Haiti, com a consequente origem comum escravocrata do povo haitiano e do soldado brasileiro, além da extrema pobreza daquele povo, possuem semelhanças em algumas regiões do nosso país, e nosso soldado percebe isso. Tudo isso se alia às dificuldades do dia-a-dia, tendo o povo haitiano que labutar para ter algo que comer, sujeitando-se ao emprego informal, ou ganhando pouco na informalidade, além da forte manipulação e exploração política às quais o povo é constantemente submetido. $(2017, \text { p. } 61)^{215}$

E, por fim, há também análises na teoria das RI, em colaboração com intelectuais militares, que destacaram, mediante abordagens pós-coloniais e da $\mathrm{Paz}$ Híbrida, a especificidade, eficácia empírica e superioridade normativa de uma intervenção majoritariamente composta e liderada por militares de países que já foram colônias europeias, como no caso do Brasil e demais países latinoamericanos durante a MINUSTAH (MORENO et al., 2012). Tais contingentes teriam "mostrado um engajamento alternativo com a diferença", um "comportamento conciliatório" e "maneiras inovadoras" de lidar com os dilemas encontrados, somente tornadas possíveis pelo "estabelecimento de relações mais empáticas", uma vez que "ao trazer para campo memórias compartilhadas de sofrimento" eles seriam capazes de "reconhecer seus Outros (pós-coloniais) internos". Esta "ambiguidade" do lugar de fala brasileiro sobre o Haiti produziria um hibridismo capaz até de "desestabilizar o imaginário civilizacional reproduzido pelo modelo da paz liberal" (MORENO et al., 2012, p. 383-384; 388).

Trata-se de um vasto e multifacetado rol de explicações que convergem para a originalidade do suposto "sucesso" brasileiro no Haiti sob a MINUSTAH. ${ }^{216}$ Explicações que também são reiteradas pelas vozes brasileiras in situ. Elas recorrem aos diferentes elementos elencados pelas literaturas simpáticas à intervenção a fim de articular suas falas e representações, dando mostras, assim, do poderio deste

\footnotetext{
${ }^{215} \mathrm{O}$ segundo fator de sucesso elencado pelo coronel, "[a] similaridade com os problemas de segurança pública", também é digno de nota: "a presença de grupos armados exercendo poder sobre uma determinada área ou região, onde a forte violência de gangues armadas produz fartura de exposição de corpos feridos e cadáveres. Essas características de Porto-Príncipe em nada chocaram o soldado brasileiro, que sabia lidar com esses problemas com desenvoltura e naturalidade" (MENDONÇA, 2017, p. 62).

${ }^{216}$ Para uma análise de reportagens contendo discursos sobre o suposto "sucesso" da atuação brasileira no Haiti como forma de legitimar a intervenção federal nas forças de segurança pública do Estado do Rio de Janeiro, em 2018, ver Borba de Sá (2018).
} 
regime discursivo, amplamente difundido. Serão observadas neste capítulo as narrativas de autoridades governamentais e funcionários da burocracia estatal, policiais e religiosos, cotejando-as com fontes da imprensa, academia e sociedade civil organizada. O destaque analítico é oferecido para as entrevistas originais feitas no Haiti com brasileiros que estavam no país caribenho a serviço da MINUSTAH ou atuando em colaboração com esta força de intervenção, pouco antes de seu término, em outubro de 2017.

Estas narrativas produzidas por vozes brasileiras entrevistadas em solo haitiano no âmbito da MINUSTAH serão apresentadas neste capítulo mediante uma subdivisão em três tropos que captam os modos de articular os discursos sobre o Haiti, conforme produzidos por seus enunciadores brasileiros: (i) discursos de caos e ordem; (ii) ontologias da alteridade; e (iii) teleologias da modernização que infantilizam e negam agência, inteligência ou competência ao Outro haitiano. Tais tropos permitem observar as expressões de colonialidade e biopoder (re)produzidas neste regime discursivo. Nele, pode-se notar como o problema da colonialidade se enreda com o do biopoder nos termos propostos por Santiago Castro-Gómez (2006), que afirma: "Foucault quer traçar uma genealogia do modo em que o discurso da superioridade física, étnica e moral de umas populações sobre outras se converte em um dispositivo biopolítico do Estado moderno" (2006, p. 158). ${ }^{217}$ Este capítulo provê exemplos originais deste tipo de formação discursiva que também opera como mecanismo de poder nas vozes brasileiras sobre o Haiti. ${ }^{218}$

\section{Narrativas de caos e produção da ordem}

As alegorias de anarquia, caos ou desordem envolvendo o Haiti são ativadas por vozes provenientes de diversas comunidades epistêmicas e forças sociais no Brasil. Na academia brasileira, um exemplo paradigmático desta ativação é oferecido por Seitenfus (2006), que foi um importante formulador de explicações sobre a importância de intervir em um Haiti descrito mediante linguagem

\footnotetext{
${ }^{217}$ Para uma discussão sobre o conceito de dispositivo na obra de Foucault, ver Agamben (2005).

${ }^{218}$ São analisados os resultados de seis entrevistas semiestruturadas (com questionário fixo, porém com condução flexível) realizadas pelo autor entre janeiro e fevereiro de 2017 no Haiti. Tendo em vista que se trata de uma abordagem qualitativa, a expressão numérica da amostra não almeja abarcar um índice quantitativamente representativo dos discursos existentes, mas captar nas enunciações disponíveis expressões de colonialidade e biopoder ilustrativas deste regime discursivo. Como não se trata de denúncia, a identidade dos entrevistados será mantida em anonimato, indicando-se somente a posição ou natureza do cargo exercido pelas vozes entrevistadas. Para uma discussão sobre metodologias qualitativas de pesquisas em Relações Internacionais baseadas em entrevistas, ver: Leander (2015) e Brinkmann e Kvale (1996).
} 
literalmente hobbesiana (antes de se transformar em ferrenho crítico da MINUSTAH, em anos mais recentes). Sua invocação do estado de natureza e da necessidade de imposição da ordem por forças exteriores poderia figurar como exemplo paradigmático nas críticas de Beier (2002), Blaney e Inayatullah (2004), Grovogui (2006) e Jahn (1999) aos usos do imaginário contratualista e sua relação com o colonialismo moderno e a colonialidade nas teorias de RI.

Trata-se da simples ausência de Estado. Da convivência desregrada entre seres humanos abandonados à sua própria sorte, sem nenhuma possibilidade de salvação individual, diante da perspectiva de guerra eterna de todos contra todos, fruto da histórica omissão das elites internas e transnacionais, que nada mais têm a retirar dessa depauperada terra. No Haiti paira no ar uma atmosfera de suspeição e de boatos que forma a vibrante tensão de instabilidade brutal. Somente o olhar e a presença física do estrangeiro têm evitado a explosão dessa panela de pressão, a aberta guerra civil, como já ocorreu em muitos momentos da história do Haiti. (SEITENFUS, 2006, p. 9 - negrito adicionado) $)^{219}$

Dez anos após o início da MINUSTAH, o ex-presidente Luís Inácio Lula da Silva (2014) publicava artigo sobre o Haiti em diversos meios, no qual fazia um balanço da missão naquela década. Ele exortava a Comunidade Internacional e a sociedade brasileira a continuarem seu apoio ao Haiti, que estaria diminuindo, de acordo com sua percepção. ${ }^{220}$ Fora sob sua presidência, em 2004, que o Brasil iniciara a participação na intervenção militar-humanitária na ilha caribenha. Seu argumento apoia-se nas tradicionais construções discursivas de estilo hobbesiano sobre o Haiti, que destacam um ambiente de caos que, por sua vez, necessita de imposição da ordem. Um estado de natureza que clama pela (re)criação do contrato social na forma de um Estado nacional sólido, ainda que mediante ajuda externa. $\mathrm{Na}$ impossibilidade deste contrato ser (re)feito, a governamentalidade exercida por agentes exteriores faz parte da solução ao problema descrito. ${ }^{221}$

\footnotetext{
${ }^{219}$ Para uma discussão sobre os imaginários de caos e barbárie geralmente atribuídos ao Haiti nas representações ocidentais e mesmo nas latino-americanas e caribenhas, ver o livro de Eliesse Scaramal, intitulado Haiti: fenomenologia de uma barbárie (GOIÂNIA: CÂNONE EDITORIAL, 2006).

${ }^{220}$ Para ler a íntegra do artigo de Lula da Silva, ver (acesso em junho 2018): https://brasil.elpais.com/brasil/2014/02/25/opinion/1393359908_575387.html

${ }^{221}$ Nos debates disciplinares de RI, Thomas Hobbes figura como representante canônico do imaginário do estado de natureza usado para explicar a chamada anarquia internacional (BEIER, 2002). Seu uso neste capítulo serve a um propósito metonímico para ilustrar a força do pensamento contratualista/soberanista, mas que de modo algum refere-se apenas à contribuição do filósofo político britânico. Vale notar que a rejeição do contrato social em prol da análise biopolítica foi realizada por Foucault (2006, p. 33) ao analisar justamente a sua "teoria da guerra" em função do "problema da raça". Para uma perspicaz análise latino-americana (fora dos debates de RI) do modelo hobbesiano que versa sobre o momento fundacional do Estado e suas complicações teóricas, ver Pousadela (2006).
} 
Vale a pena lembrar que, no primeiro semestre de 2004, o Haiti sofreu uma gravíssima crise política que resultou na queda do Presidente Jean-Bertrand Aristide e na disputa pelo poder entre diversos grupos armados, sacrificando brutalmente a população civil. A violência e os atentados aos direitos humanos se generalizaram. Gangues de delinquentes passaram a agir livremente em PortoPríncipe, apoderando-se inclusive de prédios e órgãos públicos. Alguns dos maiores bairros da capital, como Bel-Air e Cité Soleil, foram completamente dominados por facções criminosas. Na prática, o Estado democrático entrou em colapso, incapaz de garantir condições mínimas de segurança e estabilidade para que o país continuasse funcionando. (LULA DA SILVA, 2014, s/p)

Sua representação do Haiti, mais adiante, insiste neste imaginário composto por "drama humano", "gangues de delinqüentes" e "guerra civil"; males somente superados mediante o abandono deste estado de natureza pela instauração, ou restauração, do poder centralizado do Estado, expresso pelo "controle sobre todo território nacional". O risco da guerra civil (para Hobbes equivalente à "morte do Estado") $)^{222}$ é trazido como ilustrativo da tarefa que precisava ser desempenhada, de acordo com esta lógica argumentativa. Em outras palavras, se os haitianos são incapazes de fazer seu próprio contrato social, resta aos interventores geri-los a partir do emprego de técnicas de governamentalidade sobre o Outro.

Hoje a situação de segurança se transformou profundamente: os riscos de guerra civil foram neutralizados, a ordem pública restabelecida e os bandos de delinquentes derrotados. O país foi pacificado e o Estado reassumiu o controle de todo o território nacional. Além disso, a MINUSTAH tem contribuído para equipar e treinar uma força haitiana de segurança. As instituições democráticas voltaram a funcionar e estão se consolidando. (LULA DA SILVA, 2014, s/p)

O sucesso da transição descrita neste tipo de narrativa é creditado à MINUSTAH. Para Lula da Silva (2014), a composição da força, em sua maioria de soldados sul-americanos e comandados por generais brasileiros, explicaria este êxito. A atitude diferenciada destes interventores pós-coloniais, segundo tal lógica,

${ }^{222}$ Não à toa o ex-chanceler brasileiro Celso Amorim referiu-se ao papel da Comunidade Internacional como o "ventre" onde agitar-se-ia "a vida do novo Haiti", dados os sucessos da estabilização e reconstrução do Estado trazidos pela MINUSTAH, em sua opinião (AMORIM, 2006, p. 3). Hobbes (2012) desenvolve analogias organicistas e mecânicas para expor suas teses sobre o Estado moderno, onde lê-se que: "Na realidade, graças à arte criamos esse grande Leviatã a que chamamos República ou Estado (em latim, Civitas), que nada mais é que um homem artificial, bem mais alto e robusto que o natural, e que foi instituído para sua proteção e defesa; nele, a soberania é uma alma artificial que dá vida e movimento a todo o corpo; os magistrados e outros oficiais de justiça e execução são ligamentos artificiais; a recompensa e o castigo (mediante os quais cada ligamento e cada membro vinculado à sede da soberania é induzido a executar seu dever) são os nervos, que fazem o mesmo no corpo natural; a riqueza e a abundância de todos os membros particulares constituem sua potência; a salus populi (a segurança do povo) é seu objetivo; os conselheiros, que informam sobre tudo o que é preciso conhecer, são a memória; a equidade e as leis, uma razão e uma vontade artificiais; a concórdia é a saúde; a sedição, a enfermidade; a guerra civil, a morte" (2012, p. 15-16 - negrito adicionado). 
configura-se como uma "marca registrada" $(2014, \mathrm{~s} / \mathrm{p})$ desta tecnologia brasileira de produção da ordem e da paz mediante instauração de um Estado moderno, com nítidos traços liberais, porém com características particulares à uma nação do Sul, facilitadoras de tal empreitada.

Um general brasileiro comanda a componente militar da missão, que conta com soldados de dezenas de países, e é integrada majoritariamente por tropas de nações sul-americanas.

O Brasil e seus vizinhos aceitaram a convocação da ONU por um imperativo de solidariedade. Não podíamos ficar indiferentes à crise político-institucional e ao drama humano do Haiti. E o fizemos convictos de que a tarefa da MINUSTAH não se limitava à segurança, mas abrangia também o fortalecimento da democracia, a afirmação da soberania política do povo do Haiti e o apoio ao desenvolvimento socioeconômico do país. Daí a atitude respeitosa e não truculenta - de verdadeira parceria com a população local - que tornou-se sua marca registrada. (LULA DA SILVA, 2014, s/p)

Junto da atitude diferenciada dos interventores militares pós-coloniais, também são apresentadas ações na "área social” que englobam desde atividades filantrópicas até projetos de crescimento econômico, como explicações para o propalado sucesso haitiano da pacificação exterior brasileira. $\mathrm{O}$ ex-presidente defende já no subtítulo a gradual substituição "da vertente da segurança pela vertente do desenvolvimento" (LULA DA SILVA, 2014, s/p) O nexo entre segurança e desenvolvimento, que Duffield (2007) percebe como característica da paz liberal é, assim, ativado pelo discurso de Lula da Silva (2014), mesmo que seu objetivo seja justamente diferenciar as práticas brasileiras de construção da paz frente ao modelo ocidental tradicional. A crítica aos "países ricos" ajuda a ressaltar ainda mais esta particular maneira brasileira de articular suas intervenções humanitárias pós-coloniais. ${ }^{223}$

\footnotetext{
223“"Além de sua participação na MINUSTAH, para a qual contribui com o maior contingente de soldados, o Brasil tem colaborado intensamente com o povo do Haiti na área social. Com recursos próprios ou em parceria com outros países, implementou uma série de programas que vão desde campanhas nacionais de vacinação até o apoio direto à pequena e média empresas e à agricultura familiar, passando pela alimentação escolar e a formação profissional da juventude (...) Mas, infelizmente, nem todos os que se comprometeram com o Haiti cumpriram as suas promessas. A verdade é que a maioria dos países ricos tem ajudado muito pouco o Haiti” (LULA DA SILVA, 2014, s/p). Para uma análise teórica que também menciona vacinações e percebe a operação da colonialidade e do biopoder em tais "zonas de indistinção entre cooperação e conflito, diplomacia e governança" ver Constantinou e Opondo (2016, p. 310-315). A Revista de Ciências Militares do Exército Brasileiro traz abordagens que dialogam diretamente com estas práticas. Ver, por exemplo, o artigo intitulado A Medicina Veterinária Militar Brasileira em Operações de Paz: experiências colhidas na Missão da Organização das Nações Unidas para Estabilização do Haiti (BARROS et al., 2013).
} 
Não apenas no discurso acadêmico ou governamental esta transição hobbesiana, via intervenção exterior, é apresentada como obra e legado da MINUSTAH no Haiti. O livro do jornalista Luis Kawaguti, A República Negra (2006), também promove a mesma operação discursiva entre caos e ordem. Esta obra, lançada pelo maior conglomerado midiático do Brasil apenas dois anos após o início da missão, apresenta uma narrativa que oscila entre a representação discursiva do Haiti como ameaçador, por um lado, e como frágil, carente e incapacitado para sua autopoiese, por outro. Um lugar que precisa ser resgatado por ação exógena, assim como sua população. Na contracapa descreve-se a obra assim:

Fevereiro de 2004. Num Haiti mergulhado na violência, o presidente Jean-Bertrand Aristide é derrubado. Explodem conflitos armados entre grupos políticos rivais. O país está à beira da guerra civil e sua população precisa de ajuda. O quadro não poderia ser mais desafiador para a estréia do Brasil na liderança de uma missão de paz da Organização das Nações Unidas (...) Este livro conta o processo de resgate do Haiti - do caos absoluto à gradual retomada do estado de direito - e mostra como a participação brasileira tem influenciado a vida e o destino dos 8 milhões de habitantes do país mais pobre das Américas. ${ }^{224}$

As entrevistas realizadas durante a pesquisa de campo no Haiti também ativam este expediente discursivo baseado na transição securitizante acima descrita: do caos à ordem, conquistada pela eficiência da MINUSTAH sob comando brasileiro. O coronel que desempenhava, em 2017, a função de subcomandante do Batalhão Brasileiro (BRABAT) ${ }^{225}$, parte do Contingente Brasileiro da Força de Paz (CONTBRAS) descreve uma situação de desordem e vazio de poder encontrada pelas tropas brasileiras antes de avançar a solução produzida pelos

\footnotetext{
${ }^{224}$ Kawaguti (2006, contracapa). Uma forte crítica à narrativa que apresenta o Haiti como o país "mais pobre das Américas" está no instigante trabalho de Gina Ulysse (2015, p. 55): "To the West, Haiti is popularly known as "the poorest nation in the Western Hemisphere" - code for "poor and black. But invisible in this tagline are the wealth and culpability of the elite 3 percent of the populace, primarily descendants of European immigrants (many married Haitian women to bypass the constitution and become landowners)". Mais adiante, ela volta ao tema: "Others, like myself and die-hard Haitiphiles, have been preparing for the bombardment of "the poorest nation in the Western Hemisphere" taglines that accompany every segment. We know that the misery of those ding of cholera and of the homeless in tent cities is being further exposed in aggressive zooming shots to offer a more human side of the tragedy. As expected, features shied away from history, favoring sound bites on the Haitian government's failures since January 12, 2010. Unsurprisingly, not enough attention is being paid to the role that foreign nations and international institutions have and continue to play in our predicament" $(2015$, p. 60$)$.

${ }^{225}$ Brazilian Batallion, em inglês.
} 
militares. Antes "não tinha nada"226, mas depois da intervenção "você anda tranquilamente", afirma.

Em 2004 não tinha nada, o país não funcionava. Não era possível governar. As pessoas não andavam na rua, não andavam nas favelas, então era totalmente dominado pelo tráfico. Hoje isso acabou-se, você circula em qualquer área. Vocês foram à Cite Solei? [Não]. Onde tem lá a primeira... Era uma das favelas mais perigosas daqui. Hoje você anda na favela, a gente faz a segurança de manhã, a tarde e a noite, e você anda tranquilamente. Então a ONU tem a sua avalia, ela entra, ela sem dúvida, como falei, não tem nada melhor no mundo.

O subcomandante reitera este imaginário repetidas vezes ao longo da entrevista, cuja duração alcançou cerca de uma hora, na confortável sala montada dentro de um dos containers do BRABAT, em Porto-Príncipe. Apesar da insistência no sucesso da transição de "um país que parou de funcionar" para outro caracterizado por "segurança" e "tranqüilidade", ele próprio admite que este sucesso é "frágil”" e depende da presença ostensiva de militares e "demonstração de força” permanente. A estabilização, neste discurso, é temporária e dependente da presença estrangeira, revelando a incredulidade do enunciador quanto à resiliência da pacificação e sugerindo uma tendência ao retorno da guerra de todos contra todos no momento em que força militar se retirar do país.

Você pegar um país que parou de funcionar, fazer essa máquina voltar a funcionar, é um processo complexo. Nós militares, a gente só garante a segurança. Nossa missão é: manter o ambiente seguro e estável. Que é o que a gente está fazendo aqui. Patrulha de manhã, a tarde e a noite, e quando a coisa engrossa ali a gente aperta também, né. E mantém esse país, em que você tem a percepção de segurança, ela existe no país hoje. De tranqüilidade. Você pode falar que ela é volátil, que ela é frágil. Ela é. Enquanto nós estamos aqui, está garantido. Quando nós sairmos, eu não sei.

Ao contrario de Lula da Silva (2014) e Kawaguti (2006), o subcomandante assegura em duas oportunidades que no Haiti “não houve guerra civil”. Ele descreve os eventos que culminaram na derrocada de Aristide como "uma marcha caminhando de Gonaïves para Porto-Príncipe em 2004, que ia tomar o poder, porque o governo já não dominava nem toda a capital". Não tanto um caos generalizado, portanto, mas uma disputa entre grupos políticos rivais que minou o

\footnotetext{
226 Tais representações novamente dialogam com o imaginário hobbesiano, assim como com a mitologia cristã da Criação, ao enunciarem que "antes não tinha nada". Note-se que para Hobbes, "os pactos e convênios, mediante os quais as partes desse corpo político se criam, combinam e se unem entre si, assemelham-se àquele fiat ou "façamos o homem" pronunciado por Deus quando da Criação" (HOBBES, 2012, p. 16 - itálico no original).
} 
poder estatal, uma vez que "em várias áreas o governo não entrava". Situação agravada, em sua avaliação porque "não tinha exército", dissolvido ao fim do primeiro mandato de Aristide em 1994 "porque os golpes militares eram seguidos aqui”.

A narrativa do subcomandante insiste na necessidade de patrulhamento ostensivo e permanente, mesmo decorridos treze anos após os incidentes por ele descritos. “Agora, lógico, isso não é de graça. Reação-presença, demonstração de força, dissuasão o tempo todo". A capacidade bélica e a constância ininterrupta da militarização do cotidiano haitiano são enfatizadas pelo subcomandante: “o soldado está o tempo todo muito bem armado, muito bem equipado, na rua, na rua, na rua o tempo todo". A impressão que transmite é que só há ordem quando se tem armas nas ruas, em grande quantidade e, naturalmente, em mãos corretas: não haitianas.

Sua fala, no entanto, oscila significativamente ao identificar os "spoilers" que dificultam a produção da ordem no Haiti, ora admitindo que se trata de luta política, ora retomando a narrativa sobre os "desafios" proporcionados por "gangues". Esta última visão, das gangues, conforme visto no artigo de Lula da Silva (2014), está mais de acordo com a linha oficial do governo brasileiro. Embora seja a versão que prevaleça na maior parte do tempo de entrevista, sua conclusão insiste que era preciso tropas militares (e não somente policiais) para "controlar o país".

No entanto aqui não teve guerra civil para ter um peace agreement, o que tinha eram gangues que controlavam o país, boa parte do país. Então o desafio nosso foi um desafio que a gente chama no Brasil, por exemplo, de Garantia da Lei e da Ordem, é segurança pública. Ah então segurança pública não deveria ser polícia e não militares fazerem esse tipo de trabalho? Não aqui. Não aqui. Aqui precisava de uma estrutura de tropa pra realmente controlar o país. Agora nós estamos tentando passar para a segurança pública, aos pouquinhos, que é a Polícia Nacional Haitiana. Para que eles assumam esse trabalho. Mas inicialmente não tinha como você pegar uma polícia... Vou pegar a Polícia Militar de São Paulo e botar no Haiti: não tinha condições. Tinha que ser exército, né, dos países, como foi.

Tamanha desordem não é controlável apenas mediante esta militarização strictu sensu, conforme os proponentes do soft power brasileiro haviam alertado (CARVALHO, 2017; KALIL; NAPOLEÃO, 2015; MENDONÇA, 2017; VIANA, 2009). Para "realmente controlar o país", objetivo declarado das técnicas de governamentalidade empregadas, o subcomandante informa que também são necessários complementos extracoercitivos, na forma de um "trabalho de operações 
psicológicas". Neste momento, aparece um terceiro sujeito social em seu discurso, que igualmente atua como oponente da MINUSTAH: a população haitiana. Além de grupos políticos e gangues, houve enfrentamento contra civis desarmados, porém hostis, às tropas internacionais durante a intervenção no país. ${ }^{227}$

\begin{abstract}
A tropa levou muita pedrada, deu tiro de borracha etc. Posteriormente nós fizemos um trabalho de operações psicológicas mostrando para eles que nós não temos nada a ver com isso. Sabe, a gente está ali para fornecer segurança, pra fazer segurança de comboio humanitário, de alimentos. E a população entendeu e acabou.

(...) A gente mandou lá agora na região sul, sudoeste, eu estava lendo um relatório hoje do destacamento de operações psicológicas, que foi fazer um trabalho lá pra poder acalmar o pessoal lá, para pararem de hostilizar a tropa.
\end{abstract}

Frente a estes três tipos distintos de ameaças à ordem, seu relato conclui que a única maneira de realizar o mandato da missão é via "dissuasão permanente". Após mais de uma década de operações militares, o subcomandante informa que "tem resolvido 99,9\% do nosso trabalho aqui só com dissuasão. Só com demonstração de força, que é o ideal. E o nosso soldado, ele está preparado para isso". Apesar de admitir que "as gangues continuam existindo em função de um problema social", ele informa que foi alcançada uma espécie de coexistência pacífica entre elas e as tropas da MINUSTAH. Salta aos olhos a criminalização da pobreza que seu discurso naturaliza ao celebrar a recuperação do quase-monopólio estatal sobre a violência.

Há muitos anos que a gente vem numa situação que não tem mais o confronto. As gangues haitianas não procuram mais o confronto com a tropa. Porque eles já perceberam que não tem como. Então eles evitam o confronto, a confrontação (...) Há um problema social no país pela falta de uma economia, que ainda tem dificuldade de girar, é baseada aqui na economia informal. Isso então, em qualquer lugar de pobreza existe a gangue. Mas elas não têm nem de perto a força que elas tinham em 2004. Não dominam áreas, são alguns localizados ali, mas não dominam áreas e não interferem no nosso trabalho.

Ao contrário de estudiosos críticos da MINUSTAH como Lemay-Hérbert (2015), Seguy (2014) e Seitenfus (2016), o subcomandante considera que os problemas de governabilidade do Haiti são sempre oriundos de fatores domésticos, ao passo que as soluções são, naturalmente, advindas do exterior, incluindo os logros da frágil democracia política no país. Mediante assertivas que ilustram as teses de Chandler (2006) sobre a desresponsabilização dos interventores

\footnotetext{
${ }^{227}$ Sobre discussões acerca da Raiva ou Fúria colonial (do colonizado frente ao colonizador), ver:
} Chakravarti (2014), Fanon (2005) e Muppidi (2012). 
internacionais, sua narrativa assegura que "as confusões deles", haitianos, são as causas de qualquer fracasso na implementação do mandato da missão. ${ }^{228}$ Como se houvesse uma tendência natural à desordem no Haiti, caso deixado sozinho, seu discurso demonstra descrença quanto às possibilidades do país estabilizar-se por si mesmo ou dali por diante, sem ajuda externa, "afinal de contas essa é a quinta missão da ONU aqui. Que seja a última. Já tiveram quatro e o país voltou a quebrar".229

Pois é, porque aqui não foi um grupo que veio de fora para desestabilizar o Haiti. Foram de um problema social interno e que criou-se uma situação em que o governo não funcionava mais, não governava mais (...) Não, eu não considero que o Haiti é ingovernável não. O Haiti é um país entupido de demandas e de situações que podem ser melhor, mas é um país né. Tem instituições que tem que funcionar cada vez melhor, de maneira mais coordenada e tal, mas é um país. Um país que tem que melhorar. Não tenha dúvida. É um país com deficiências, mas é um país. E democrático. Tem eleição: nós não garantimos a eleição? Nós não vamos garantir agora domingo, o segundo turno? Não vamos fazer o presidente assumir no dia 07 de Fevereiro? Assim esperamos né. E quando não conseguimos, não é por causa da gente não. É por problema político interno deles aí, né, que dá as confusões deles aí. Porque pela gente, nós estamos garantindo, está tudo seguro.

Tais "confusões deles aí", isto é, dos haitianos, são tratadas como objeto de repressão militar (estrangeira), mas não de embates próprios ao jogo político como em qualquer outro lugar, mesmo que o país seja “democrático”. O intervencionismo da MINUSTAH mostra, neste momento, sua face explicitamente parcial ao se envolver nos assuntos políticos internos do Haiti, conforme já denunciado, dentre outros, por Lemay-Hebert (2015) e Seitenfus (2016). Segundo o subcomandante, que iniciara a entrevista falando sobre a derrubada violenta do governo de Aristide - posteriormente chancelada pela intervenção internacional - agora a função da tropa seria exatamente proibir esta mesma conduta. Referindo-se à cerimônia de posse presidencial que acontecia na mesma semana da entrevista, ele dispara: "quem fizer manifestação violenta a gente controla. A MINUSTAH controla. Nós temos meios para isso. Agora, então você veja que é um país democrático. Um presidente saiu e está entrando outro". A repressão seletiva a um setor político é,

${ }^{228}$ Em evento comemorativo dos 13 anos da MINUSTAH, no Rio de Janeiro, em 2017, a embaixatriz Roseana Kipman repetiu este tipo de argumentação ad nauseum para um auditório composto majoritariamente por militares, em meio a risadas sobre as anedotas sobre o suposto comportamento pitoresco e pouco civilizado dos haitianos, mostrando que a diplomacia brasileira compartilha deste tipo de discurso de culpabilização do Outro identificado por Chandler (2006).

${ }^{229}$ A MINUSTAH seria encerrada meses após a entrevista, mas não foi a última missão, como desejava o coronel. Ela foi substituída pela Missão das Nações Unidas de apoio à Justiça no Haiti (MINUJUSTH), também ancorada no capítulo VII da Carta da ONU. 
deste modo, apresentada como fator ilustrativo da modernização política trazida de fora para dentro do país: As armas são os "meios" que garantem a democracia no Haiti ocupado.

Ao fim, em que pese a predominância desta linha argumentativa, o subcomandante do BRABAT considera que o Estado no Haiti "não é falido", mas "é um Estado com deficiências". Em sua concepção, o que falta ao país é "arrecadação" para "garantir educação" e os demais itens por ele considerados como característicos de um moderno Estado nacional, todos ligados ao aparelho jurídico-penal estatal: "Law and order né, porque law and order é polícia na rua, é sistema carcerário, é judiciário funcionando. Ele tem que ter”. Enquanto tais dispositivos de biopoder não estiverem consolidados, a intervenção estrangeira tem como objetivo principal uma tarefa autorreferenciada, já explicitada nas duas resoluções do Conselho de Segurança da ONU que criaram a MINUSTAH: "o nosso papel aqui, militar, o que é? É só garantir a segurança para que as agências da ONU trabalhem".

Desta forma, conforme já percebido por autores como Chandler (2006), Duffield (2005, 2007) e Heathershaw (2008), o discurso das intervenções humanitárias - que engloba práticas e narrativas - termina servindo a si mesmo, dentro de uma lógica virtualmente autocentrada, que produz sua própria perpetuação no tempo e em novos espaços. ${ }^{230}$

Então tudo isso, eu diria para você, que o Brasil hoje projeta poder usando o poder militar, por meio do poder militar. O poder militar, a tropa brasileira no exterior, a desenvoltura, a capacidade de liderança, de planejamento, fez com que a gente avançasse com a credibilidade de que você pode considerar isso uma projeção de poder. A projeção de poder você pode conseguir através do poder científicotecnológico, do próprio tecido social, do militar, do político, do econômico. Nós conseguimos através do poder militar, essa projeção de poder. E essa credibilidade que a gente não pode perder, nunca, dentro da ONU. Tanto é que no dia em que fechar a MINUSTAH, o Brasil tem que mandar tropa pra outra frente. Isso já está sendo trabalhado, né, para que a gente não perca esse know-how e toda essa credibilidade. Isso em reflexos em diversas áreas. ${ }^{231}$

\footnotetext{
${ }^{230}$ Para uma exposição sistemática deste imaginário que defende expansão constante da participação brasileira em operações de paz, ver Cezne e Hamann (2016), Kenkel (2011) ou, especialmente, Abdenur e Hamann (2017), este último disponível em (acesso julho/2018):

http://diplomatique.org.br/o-futuro-do-brasil-nas-operacoes-de-manutencao-da-paz-da-onu/ Para uma resposta direta a este argumento, que enfatiza o risco da exportação das práticas brasileiras de controle e repressão de setores populares e identificados por sua negritude durante operações de pacificação via militarização, ver: Borba de Sá et al (2017) disponível em (acesso julho/2018): http://diplomatique.org.br/militarizacao-tipo-exportacao-o-perigo-da-industria-humanitariabrasileira/.

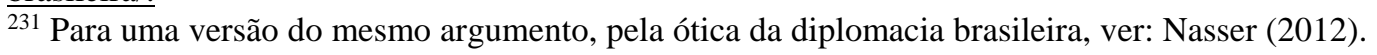


Uma narrativa similar foi encontrada na entrevista com o responsável pelo Escritório de Informações Públicas da MINUSTAH (MPIO) ${ }^{232}$ em Porto-Príncipe, um tenente-coronel da Força Aérea Brasileira (FAB), para quem os "stake-holders" de territórios sob intervenções humanitárias na África são apenas "tribos". ${ }^{233}$ Ele reitera a colonialidade presente no imaginário de violência sobre o Haiti para, em seguida, mencionar o "carisma" e a "maneira diferenciada" dos brasileiros atuarem em locais perigosos - negros e pobres - nos quais as pessoas estariam a matar-se barbaramente umas às outras, neste discurso:

Então, o Haiti é um país que ele enfrenta muitos casos de crimes, de assaltos, de homicídios. Recentemente a ONU estava até muito preocupada com a questão dos linchamentos que acontecem às vezes. Ou seja, pessoas querendo fazer justiça com as próprias mãos. Então é um país violento em geral (...). Há casos durante protestos, coisas assim de algumas viaturas nossas serem atacadas. É, há casos de jogarem pedras, de coquetel Molotov. Às vezes acontece, mas isso aí faz parte da missão (...) A gente pode dizer que o brasileiro, ele tem, o militar brasileiro, o civil também, eles têm uma maneira diferenciada, muitas vezes, de lidar com o pessoal daqui. Isso acabou gerando assim uma aceitação muito boa do militar aqui, um carisma muito grande que eles têm pela gente. Eu acredito que é isso.

Esta ênfase no aspecto disciplinar e no poderio bélico-político sobre populações também aparece na entrevista com um policial brasileiro servindo na MINUSTAH. Apesar de ter tido o comando do braço militar da missão e o maior número de soldados durante toda sua duração, o Brasil possuía, em 2017, somente três policiais atuando no Haiti como parte da Polícia das Nações Unidas (UNPOL), integrante da MINUSTAH. O policial argumenta que "aqui no Haiti não existem Forças Armadas no momento, então a única instituição armada do Estado é a Polícia Nacional Haitiana". Isto mostraria, segundo sua percepção, "que o empenho dos policiais é de extrema importância, principalmente aqui na MINUSTAH”. Em sua

\footnotetext{
${ }^{232}$ Sigla em inglês para MINUSTAH's Public Information Office. O tenente-coronel, apesar de estar lotado na repartição onde recebe-se jornalistas e pesquisadores, afirmou que não sabia responder a maioria das perguntas do questionário, por haver chegado há pouco tempo no Haiti. Foram 21 negativas em 39 minutos de entrevista, realizada no próprio MPIO do Campo Delta da MINUSTAH. ${ }^{233}$ Sobre a relação entre racismo e a ontologia que percebe apenas "tribos" em comunidades políticas não-ocidentais, no contexto de intervenções humanitárias, ver Vitalis (2000, p. 341). Publicações do Exército Brasileiro reforçam este imaginário sobre o Outro como objeto de interesse exótico: "Destarte, um treinamento multicultural deve transcender para análises culturais, conhecendo-se, por exemplo, os grupos étnicos em presença; seus valores culturais; sua religião, hábitos e costumes; padrões de comportamento a serem evidenciados, a fim de se vencer as barreiras identitárias; como utilizar um possível modus vivendi tribal ou comunitário em proveito das operações; como se relacionar com os civis e organismos humanitários em presença e, sobretudo, aplicar as características da formação multiétnica do povo em situações que exijam competências específicas para a prática de liderança multicultural” (CLAUHS, 2013, p. 109 - negrito adicionado).
} 
avaliação, a missão "foi sim um grande sucesso" em grande medida pela atuação policial como único "braço armado do Estado". Sua narrativa sobre a "história da MINUSTAH" informa que "havia um caos, sim, no passado", que teria sido solucionado pela intervenção estrangeira.

No que tange à criminalidade aqui, melhoramos muito na questão que diz respeito às gangues. No passado, não tão longínquo, existiam várias gangues ligadas ao tráfico de drogas (...). Aqui existiam certas gangues ligadas ao tráfico de droga, mas com a presença da MINUSTAH e a presença internacional de uma forma geral, as Forças Armadas, o BRABAT, e as outras forças armadas de outros países, reduziu bastante. Ainda temos problemas de segurança (...). Mas não há de se falar mais no caos total com relação à segurança, o que a gente notou no passado no país.

Esta transição hobbesiana - do caos à ordem via força policial ou militar estatal - assemelha-se ao discurso de Lula da Silva (2014), Kawaguti (2006), Seitenfus (2006), assim como do subcomandante do BRABAT no Haiti e do representante do escritório de comunicação pública da MINUSTAH. Novamente as vozes brasileiras apresentam os problemas de segurança como produto de fatores internos ao Haiti e, naturalmente, as soluções como externas. Quando perguntado se o Haiti provoca medo em outros países a resposta é direta: "sim". Conforme alertado, dentre outros, por Constantinou e Opondo (2016, p. 312) e Duffield (2001, p. 22-43), o policial repete a noção securitizante acerca do desenvolvimento econômico, própria à ótica da paz liberal, ao concluir taxativamente seu raciocínio: "o subdesenvolvimento, ele traz medo", diz. ${ }^{234}$

Segundo o policial, "aqui a gente é o quintal dos EUA" e esta potência tem motivos para se preocupar com "tráfico de drogas, comércio, rotas, né, de drogas. Esse tipo de coisa". Nesta visão, o subdesenvolvimento haitiano, endogenamente produzido, é o "que leva consigo problemas, né, problemas sociais, problemas em relação à segurança" até para fora de seu país. Na resposta seguinte, sobre as resoluções do Conselho de Segurança da ONU, ele insiste neste imaginário, elaborando-o ainda mais, de modo que a fornecer um exemplo daquilo que Persaud (2002, p. 56) identificou como a noção de "segurança civilizacional", ou seja, o

\footnotetext{
${ }^{234}$ Os autores mencionados observam: "The most troubling implication of this merging has been the blunt definition of development as a danger, a condition that breeds insecurity in both domestic and international spheres, thus legitimating the peace and war interventions of neoliberal governmentality and the contemplation of transforming entire societies" (DUFFIELD, 2001 citado por CONSTANTINOU; OPONDO, 2016, p. 312 - negrito adicionado).
} 
“medo da erosão civilizacional” (2002, p. 77-80). ${ }^{235}$ O Haiti é identificado pela sua pobreza e, sub-repticiamente, por sua negritude, o que conduz à uma comparação com países africanos e favelas. São lugares que exportam "problemas" na visão do policial brasileiro (que, vale notar, é branco).

Ó, em minha opinião, os países desenvolvidos, como por exemplo os EUA, eles não querem ter um Haiti no quintal da casa deles. Por que? Agora que eu vou te explicar porquê. Países pobres, onde existem conflitos internos, eles acabam exportando pras regiões próximas problemas. É o que a gente vê atualmente acontecendo na Europa, onde os países que vivenciam guerras, países pobres da África, estão mandando sua população para esses países. Então, é, no meu ponto de vista esta desestabilização poderia também ser nesse sentido.

(...) Também, imigração. Talvez uma chance de disseminação da criminalidade daqui. Uma exportação da criminalidade, de grupos armados, que a gente já teve aqui no passado. Ninguém quer conviver, ninguém quer conviver numa favela.

Esta afirmação é reiterada logo em seguida, com a qual fecha seu argumento causal entre subdesenvolvimento e insegurança, fornecendo uma ilustração paradigmática também para as teses de Escobar (1995), Duffield (2005) e Quijano (2000) acerca da securitização e criminalização de povos, saberes e modos de vida considerados não ocidentais. Seu medo sobre a "segurança civilizacional" do ocidente (Persaud, 2002, p. 56) serve como amostra da atualidade, ou atualização, das narrativas de medo branco identificadas por Azevedo (2004) em relação ao Haitianismo no século XIX. Pobreza e crime se espalham como bactérias ou vírus, ameaçando territórios de luxo que lhes são contíguos.

Todo mundo quer a zona sul do Rio de Janeiro. Essa que é a verdade. Eu não quero uma favela próxima da minha casa. Eu quero morar num bairro nobre, essa é a questão. Assim como no Rio de Janeiro. O problema que está numa favela, se você não tomar conta dele, ele pode espalhar ali pros bairros que estão ao redor. Que tipo de problema? Violência, subdesenvolvimento, é sempre uma ameaça ali que, apesar de não estar chegando em você, você vai ter sempre ela na mente.

Mesmo assim, o policial entrevistado demonstra confiança nas técnicas de governamentalidade empregadas pelo Brasil. O Haiti, para ele, "não é um país ingovernável não. Não existe lugar que não seja governável (...) Basta criarmos

\footnotetext{
${ }^{235}$ Randolph Persaud (2002) combina diferentes análises pós-positivistas para discutir uma das formas como se expressa o racismo hoje: a noção de segurança civilizacional. Seu estudo de caso refere-se aos grupos nativistas/supremacistas brancos dos EUA, que articulam um discurso de defesa contra a suposta ameaça proporcionada pelos imigrantes asiáticos e latino-americanos àquele país. Trata-se, portanto, de uma política de "manejo da cidadania cultural" (2002, p. 79), que aparece como necessária para garantir a "segurança identitária" (2002, p. 77), a "segurança cultural da América" (2002, p. 69), de modo a preservar a "segurança nacional-civilizacional" (2002, p. 80).
} 
condições para que o governo aqui possa exercer de fato a sua autoridade", informa. E tais condições referem-se ao nexo segurança-desenvolvimento percebido por Duffield (2007) no contexto das intervenções da paz liberal. Tal nexo, aprofundado teoricamente por Constantinou e Opondo (2016) como a fusão entre defesa, desenvolvimento e diplomacia, é descrito como uma "palavra-chave" pelo policial brasileiro da MINUSTAH:

Mas também para melhorar a ordem aqui a gente precisa de estrutura, a gente vê as ruas aqui, o estado deplorável que as vias estão, esgoto, sistema de saneamento básico, sistema de esgoto, coleta de lixo, então precisa todo um desenvolvimento. Acho que a palavra-chave é essa: desenvolver para garantir a segurança.

Ao responder à pergunta sobre o controle de protestos, o policial enuncia a transição de um estado pré-existente, repleto de imagens de violência, em direção a um tempo presente em que tais desafios à ordem estão superados, ou severamente mitigados. Mesmo que as forças estrangeiras atuem "não diretamente" na contenção de distúrbios políticos no país ocupado, sua narrativa sugere que o assessoramento externo é fator causal nesta transição para um estado pacificado, ainda que saliente a brevidade deste cenário no qual as técnicas de controle mostram-se exitosas. E acrescenta: "Sim, a gente ainda tem essa necessidade sim. Mas não é tão recorrente como no passado. Mas ainda tem, ainda existem sim, protestos violentos, queima de carro, atentado contra autoridades. Temos, sim". Uma ordem que não impõe por contrato social, mas pela força pura.

Não é apenas nos círculos militares e policiais brasileiros na MINUSTAH que se vocalizam narrativas de caos e ordem. Também na embaixada e no consulado do Brasil em Porto Príncipe este tipo de representação sobre o Haiti é reproduzido, por vezes até com mais intensidade quando narrado por vozes diplomáticas. É o caso, por exemplo, do vice-cônsul do Brasil em Porto Príncipe que, em uma entrevista de 55 minutos, mencionou a palavra "caos" (ou "caótico") por sete vezes, em meio a descrições elaboradas de seu medo branco. Ao ser perguntado porque a ONU estava presente no Haiti, ele responde diretamente: sem as forças estrangeiras, o Haiti "vira o caos mesmo".

Bom, primeiro pra se... eu falo aí um pouco pela MINUSTAH. A missão militar é para estabelecer a ordem. Eu tenho a impressão e eu tenho muito medo que ... porque ano passado muito foi dito que a MINUSTAH ia embora do Haiti e a gente ficou com medo, porque não sabe. Qualquer... volta e meia tem rebeliões assim, o pessoal vai pra rua e a gente fica com medo. Inclusive é aconselhado a não vir 
trabalhar. A ONU eu acho que está aqui pra garantir mesmo, junto com as forças de paz militares, pra garantir mesmo a paz. Porque... senão eu acho que vira o caos mesmo, sabe? Graças a Deus as missões de paz da ONU estão se mantendo.

O diplomata brasileiro prossegue nesta linha ao ser perguntado sobre o balanço da última década de missão no país. Aquele "caos" narrado com tanta certeza na resposta imediatamente anterior torna-se mera suposição logo em seguida, transformando-se em algo "que devia ser antes da missão da ONU aqui". ${ }^{236}$ Uma mera "impressão", não mais a confiança absoluta narrada inicialmente, que fica, assim, restrita, ao âmbito estritamente discursivo do imaginário hobbesiano enunciado anteriormente. Um discurso que precisa de imagens de caos e anarquia prévias à intervenção. De acordo com alguns analistas, o estado de natureza funcionaria como uma "ideologia dominante" na teoria das RI (JAHN, 1999, p. 434). Uma que também pode ser usada para legitimar colonialismos para dentro, conforme estudado por Beier (2002). Tal recurso mostra-se poderoso também para o diplomata brasileiro, que enfatiza a transição rumo à ordem proporcionada pela força armada estrangeira:

Olha, eu não peguei o início da coisa, então o caos devia ser muito pior. O caos social mesmo, saque, roubo e tudo o mais devia ser muito pior. Mas agora, pelo menos, você pode andar nas ruas. Eu acho que a grande diferença que foi proporcionada aí nesses 12 anos [de MINUSTAH] é uma certa estabilidade social, de ordem, de poder ir e vir, né?

Quanto mais o vice-cônsul avança em sua reflexão, mais a narrativa sobre “caos" ganha ares de suposição, assim como a diferença em relação ao passado vai sendo borrada, uma vez que os mesmos indícios de desordem permanecem visíveis ao seu olhar atual. Por outro lado, as conclusões e o sentido biopolítico de sua fala permanecem firmes, reafirmando a importância da intervenção externa para tirar o país desse estado de insegurança humana. Há destaque também para os riscos à propriedade privada, neste "caos social" de um regime de verdade que comprova a si mesmo, mediante repetições das ideias centrais, sem recorrer a indícios empíricos mais consistentes.

Porque eu acho que antes aqui o negócio era bem caótico mesmo. Essa é a minha avaliação. Acho que pra uma avaliação precisa... seria bom você perguntar a alguém que estivesse aqui a mais tempo, né, principalmente nessa área social. Mas assim é o que eu sinto. Quando eu saio daqui eu vou almoçar em casa, vou no

${ }^{236}$ Itálico adicionado. 
mercado. Eu não sei se isso antes da ONU aqui como é que era isso aqui. Você pode ver que qualquer lojinha, qualquer supermercado tem os guardas armados com escopeta, não é revólver, é escopeta! É que é pra dar um tiro e parar o cidadão mesmo, né, você não ter chance de se mexer, se locomover, de sobreviver. Eu acho que isso aí retrata um pouco o caos que devia ser antes da missão da ONU aqui, estabelecer a paz. Enfim, isso já é um sinal de como que devia ser. Eu moro num prédio, um condomínio que também os guardas são armados, sabe? E o meu condomínio não é nenhum condomínio de luxo, não, é um condomínio mediano. Tudo aqui tem guarda com escopeta. Eu tenho a impressão que na época que devia ser o caos social, devia ser assim... se você tivesse armado, era você ou ... mas é isso.

Quando perguntado sobre quem seria o principal inimigo da MINUSTAH no Haiti, o vice-cônsul identifica a população local como alvo: "Olha, eu acho que são os próprios haitianos, né". Imediatamente, ele complementa com uma distinção de classe menos afeita às abordagens contratualistas e mais próxima de teorias da dominação social e econômica em escala internacional, como as defendidas por Duffield (2007), Pugh (2005) e Taylor (2008): não seriam todos os haitianos a serem combatidos, mas um grupo social particular, proveniente de lugares específicos. Locais e pessoas que são confundidas com a própria criminalidade $\mathrm{em}$ si.

Eu acho que o principal inimigo seriam os próprios haitianos, favelados, enfim, que querem o domínio de alguma coisa, o narcotráfico ou alguma coisa nesse sentido. Eu estou te dando uma visão muito pessoal de tudo (...) Porque os haitianos, o pessoal da Cite Soleil, eles queriam que esse pessoal fosse embora. E na Cite Soleil, que é a maior favela, né, eles inclusive têm missões, a MINUSTAH faz intervenção nesses lugares.

Assim, percebe-se, por tais narrativas, que alegorias de caos que reclamam a imposição da ordem, da razão e da civilização são constantes nas vozes brasileiras atuando no Haiti ou refletindo sobre a participação brasileira na MINUSTAH. Também fica nítido que este cenário descrito como caótico está relacionado com o tipo de visão que se tem sobre determinados traços (raciais, sociais) que identificariam a população haitiana. Na próxima seção, tais alegorias ganham um viés explicitamente hierárquico, mediante a elaboração de ontologias de alteridade que distinguem brasileiros de haitianos em termos de cultura e comportamento.

\section{Posicionamento de sujeitos: Brasil/Haiti (Brasileiros/Haitianos)}

Conforme visto no capítulo 2, Meera Sabaratnam (2013) identifica até mesmo nos discursos críticos à paz liberal uma série de "avatares de eurocentrismo", sendo que um deles é o que a autora denomina "ontologias da 
alteridade" ou "ontologias da diferença" (2013, p. 266-268; 272-273). Trata-se do hábito de enfatizar as diferenças culturais entre os países que lideram e aqueles que recebem as intervenções humanitárias. Um tipo de discurso que transmite a ideia de superioridade cultural ou civilizacional, mesmo quando tenta-se disfarçar ou suavizar esta face, nem sempre oculta, das narrativas da paz liberal, incluindo sua versão pós-colonial.

Não surpreende, portanto, que nas vozes brasileiras presentes no Haiti, e trabalhando no âmbito da MINUSTAH, tais expedientes discursivos sejam ativados com frequência. Por exemplo, as revistas militares disponíveis para consulta pública no Campo Delta, em Porto Príncipe, ensinam que o "catolicismo" é a "religião oficial" do país, ao passo que apresentam o "vodu" como "práticas místicas" decorrentes da "influência africana" (BRAENGCOY, s/d, p. 2) ou "tradições vodus" (BRABAT19, 2014, p. 7; 59), que não alcançam o status de religião nestas publicações. Nelas também se encontra imagens de cerimônias cristãs dentro de bases militares da ONU no Haiti.

Esta prática tem sido desafiada por vozes decoloniais e pós-coloniais dentro dos debates da teoria de RI, que alertam para os efeitos de tais "ontologias coloniais da diferença" (Grovogui, 2006, p. 31), em que hierarquias, imagens e percepções eurocêntricas sobre o Outro são afirmadas em paralelo à própria diferenciação discursiva. Mais do que análises neutras ou propriamente comparativas, há quem compreenda tais gestos como "apelos à clichês raciais e noções simplistas de cultura", como Siba Grovogui (2006, p. 32). ${ }^{237}$

O subcomandante do BRABAT exemplifica esta postura antes mesmo da primeira pergunta da entrevista ser feita. Seu discurso demarca com fronteiras nítidas a separação ontológica entre o Brasil, de um lado, e Angola, Libéria e Moçambique, de outro. Ao contrário destes países, "o Brasil, ele tem uma história" e uma "tradição" nas intervenções da paz liberal, "participando de várias missões das Nações Unidas". Este posicionamento do Brasil no lado interventor é acompanhado de adjetivações e imagens negativas sobre o Outro representado

\footnotetext{
237 "To the extent that they are evoked, disciplinary ontologies of difference - of civilized/uncivilized; modern/traditional; citizen/native; providential states/failed states; democratic/non-democratic - are seldom based upon a comprehensive comparative investigation of Europe and other regions in regard to "historical traditions", "political morality", and "cultural dispositions." More often than not, such distinctions appeal to racial (or ethnic) clichés and oversimplified notions of culture" (GROVOGUI, 2006, p. 32).
} 
pelos três países africanos receptores, ou alvos, das intervenções: "Então, realmente quando ela [a ONU] entra, ela ajuda, ela evita massacres, ela evita genocídios" em locais onde até o "pós-guerra [é] violento ali naquela região".

Além dos constantes anglicismos e o emprego (desnecessário) de palavras em inglês durante sua exposição, o subcomandante equipara o Brasil aos Estados Unidos da América e demais países da OTAN em seu discurso. Ao contrario dos países-alvo, como o Haiti, os interventores possuem "áreas de interesse" que lhes confeririam uma autorização para intervir quando tais interesses estiverem em jogo. Atores que, de acordo com analistas críticos do "aparato diplomático-militar" contemporâneo, "possuem um alcance global, estão preocupados com a política da vida e tem interesse na governança global de 'regiões instáveis"”

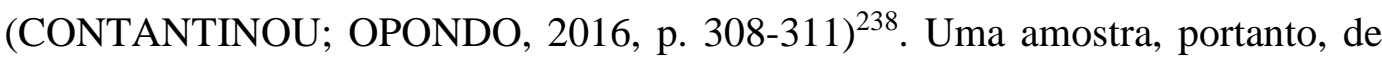
como "a biopolítica se enreda com a geopolítica" (CASTRO-GÓMEZ, 2006, p. 161). Ao fazê-lo, o coronel acaba fornecendo uma versão sobre a criação da MINUSTAH que difere da narrativa oficial da ONU e do governo brasileiro, ao passo que se encaixa confortavelmente nas proposições chamadas realistas da teoria de RI sobre o papel das instituições internacionais. ${ }^{239}$

E o Brasil, ele tem as suas áreas de interesse, né. Dentro das áreas de interesse você pode considerar que a América Latina é uma das principais. Onde o Brasil tem a sua liderança. América do Sul e, estendendo, até a América Latina. E o Brasil pretende ter cada vez mais uma projeção internacional, ele quer projetar poder, quer ser uma voz mais ativa no concerto internacional. Para isso, você tem que participar dos organismos internacionais. Como é que você pode querer ser alguém que é ouvido se você não dá a cara a tapa, se você não participa? Não é? Como nós não somos europeus, nós não nos preocupamos com a União Européia nem com a NATO, com a OTAN. Então o que nós temos é a ONU e como o Brasil é um dos signatários e sempre teve uma participação ativa, é... quando essa missão da ONU no Haiti surgiu foi quase que natural, e foi oferecido pro Brasil liderar, por que o americano ocupou aqui e falou: agora vou ter que ver, vou passar pra ONU. Por que o americano ele divide o mundo, não é? Como nós temos lá no Brasil o comando militar do sul, do norte, do leste; e o americano divide também. Então o comando sul norte-americano pega a América Latina. O problema estava no Haiti, ele mandou o comando sul dele que cuida da área, invadiu, pronto. E a ONU foi lá e substituiu, que foi o início da MINUSTAH.

\footnotetext{
${ }^{238}$ Conforme também notado pelos mesmos autores ao estudarem casos envolvendo a política norteamericana na África, mas que também servem para análise da presença do Brasil no Haiti hoje: “... the resultant interventions are at once geopolitical and biopolitical, strategic and ontological, governmental and diplomatic. The non-recognition or revulsion for the forms of political organization existing in other places contributes to engagement with territories that were traditionally considered ungovernable and intensifies concerns with the lives of foreign populations (2016, p. 310 - negrito adicionado).

239 Para uma argumentação realista acerca do papel das instituições internacionais como epifenômeno dos interesses das grandes potências, ver Grieco (1993) e Mearsheimer (1995).
} 
Nesta demarcação geo-ontológica, as linhas de insegurança (WALKER, 2006) do discurso vão construindo entidades binárias que expressam uma hierarquia nitidamente identificável entre países que influenciam e aqueles que são influenciados: "the West and the rest", nas palavras de Grovogui (2006, p. 32). Os primeiros, onde o Brasil estaria se inserindo, possuem "capacidade de planejamento, de condução, de liderança a ponto do Europeu e o americano considerarem normal ficarem subordinados à liderança brasileira", ${ }^{240}$ Já o Haiti, declarado como ameaça ao entorno regional pelas resoluções da ONU, representa o papel oposto: "Então realmente essa desestabilização [regional] eu acho que é um pouquinho de exagero né. O país não tem capacidade de influenciar outros países. O que acontece aqui dentro não tem essa capacidade".

A mesma negação de agência internacional do Haiti aparece na resposta à pergunta sobre o conceito de Haitianismo. O subcomandante (que desconhecia o termo) embarca em uma reflexão que explicita o logocentrismo subjacente à uma visão de mundo eurocêntrica. Após pedir esclarecimentos ("pra mim é um conceito novo, o que quer dizer isso?") ele contrapõe aquilo que vê como a inexpressividade internacional haitiana, ("uma ilhotazinha") com a "Revolução Francesa", esta sim, naturalmente influenciadora de acontecimentos em outras latitudes. Para ele, o Brasil nunca foi, nem poderia ser influenciado pelo Haiti.

Não, eu não. Pra mim isso é um termo novo. E não acho que a gente tenha tido
algum tipo de influência. A influência que nós tivemos na nossa própria
independência, foi reflexo de uma série de independências que vinham
acontecendo no início do século XIX e não especificamente aqui da independência
haitiana. E acredito que, ainda naquela época uma ilha aqui nessa região estava
muito distante, né, sem internet, no início do século XIX, pro que estava
acontecendo lá. Se pra chegar no Mato Grosso já era uma aventura pra Rondon,
imagina uma ilhota lá longe. Não foi a Revolução Francesa, né, a Revolução
Francesa demorou um tempinho pra fazer efeito, mas mesmo assim foi num local
que, né, França... O que acontece na França etc. Aqui era uma ilhotazinha, eu não
vejo nenhuma influência não. ${ }^{241}$
É importante salientar que esta ênfase nas representações de alteridade surgiu espontaneamente em seu discurso, em resposta a perguntas que não

\footnotetext{
${ }^{240} \mathrm{E}$ emenda: "Isso não é comum: eles se submeterem à liderança de um outro país que não seja considerado como os países de primeiro-mundo".

${ }^{241}$ A historiografia das repercussões da Revolução Haitiana sobre o Brasil foi discutida, como visto, no capítulo 3. Para o impacto da Revolução Haitiana na própria Revolução Francesa ver Blackburn (2006), Geggus (1989) e James (1989). Para uma análise da influência desta revolução sobre o pensamento filosófico ocidental a partir da silenciada relação entre "Hegel e Haiti", ver Buck-Morss (2011)
} 
necessariamente provocavam o entrevistado nesta direção. Quando indagado especificamente sobre a maior diferença entre Brasil e Haiti, sua resposta mantém a diferenciação ontológica de entre ambos, acrescentando-lhe uma metáfora indicadora da magnitude de tal diferença. Ao fazê-lo, ecoa os alertas de Walker (2013) quanto aos limites da imaginação política moderna para pensar as diferenças entre Estados: "Em termos de país, sem dúvida, a maior diferença é a capacidade econômica né. Sem dúvida, o Brasil é um gigante perto do Haiti”. ${ }^{242}$ Ao contrário do que seria o Brasil neste discurso, o Haiti é tido como economicamente arcaico, onde sobressai o patrimonialismo em vez de modernas relações entre Estado e mercado.

Por outro lado, quando instigado a refletir sobre as semelhanças entre Brasil e Haiti, o subcomandante encontra apenas traços afetivos de personalidade em comum, de tipo não intelectual, entre brasileiros e haitianos. Nada sobre política, sociedade ou mesmo um passado escravista compartilhado. Em seu discurso, o posicionamento dos sujeitos apresenta tamanha diferenciação que o único ponto em comum, extraído com dificuldade, é a “capacidade de ser amigável”. Interessa notar que o entrevistado mudou abruptamente de tema no meio de sua resposta sobre semelhanças, passando a dissertar sobre o "sucesso" da missão, quando na realidade a pergunta era sobre as parecenças entre Brasil e Haiti.

O mesmo imaginário reproduz-se na pergunta sobre a principal qualidade dos haitianos e haitianas. Novamente o entrevistado transparece certa dificuldade para encontrar uma resposta, buscando refúgio na facilidade de relacionamento entre os haitianos e os militares brasileiros atuando na ilha: "Eu diria que é a própria simpatia deles”. Sem perceber que tal simpatia pode ser fruto da subordinação ou mesmo subserviência e sujeição àqueles que portam armas e demonstram força nas ruas (conforme as palavras do próprio subcomandante no início da entrevista) ele celebra a docilidade dos corpos haitianos, ecoando os objetivos de disciplinamento descritos por Foucault (1987, p. 162-194). “O haitiano é muito simpático, ele é

\footnotetext{
${ }^{242}$ No sexto capítulo de sua obra de referência, Inside/Outside (2013), Walker é perspicaz ao captar este modo de articular a diferença entre Estados, ilustrativa da pobreza da teorização de RI sobre o espaço. Daí compreende-se o título de seu capítulo "O Estado territorial e o tema de Gulliver", em alusão à obra literária de Jonathan Swift, As Viagens de Gulliver, publicado originalmente em 1726, que simboliza, para este autor, a incapacidade do pensamento político ocidental de conceber a distinções entre Estados para além das diferenciações de magnitude. O Haiti pode ser lido, na fala do entrevistado, como ilustrativo de Lilliput, "a terra das pessoas minúsculas" (WALKER, 2013, p. 189-210). A magnitude territorial também foi apontada pelo tenente-coronel do MPIO como a diferença maior entre Brasil e Haiti, que "é nítida".
} 
muito friendly. Tanto é que a gente se dá muito bem com eles né. A gente se dá muito bem com o haitiano na rua etc.". A maior qualidade dos haitianos, portanto, é "se dar bem" com brasileiros armados à serviço militar nas ruas do país. ${ }^{243}$

Ao dissertar sobre as técnicas brasileiras de pacificação, o subcomandante do BRABAT faz uma longa digressão sobre a melhor capacidade dos brasileiros em gerir territórios e pessoas em situação de miséria. O segredo brasileiro em situações de claro exercício do poder, que Lula da Silva (2014) chamou de marca registrada, ecoa as narrativas sobre democracia racial expressas na contraposição entre Brasil e Haiti realizada por Gilberto Freyre (2004) e analisadas no capítulo 3, assim como as teses de Evaristo de Veiga e Cândido Meirelles sobre o Haitianismo, vistas no capítulo 4. Esquecendo-se que a pergunta era sobre semelhanças entre os dois países, ele ratifica uma vez mais a ontologia da diferença que coloca indubitavelmente o Brasil em uma posição de superioridade frente ao Outro haitiano, ainda que tente afirmar o contrário.

Então um dos nossos segredos, que inclusive já foi tema de palestras de nossos Force Commander nos EUA, tivemos Force Commander brasileiros que foram lá nos EUA fazer palestra sobre como nós conquistamos mentes e corações. Então o brasileiro, quando ele vai pra rua, e isso eu digo que a gente se assemelha ao haitiano, ele não vai como o superior que está ajudando o coitadinho. Ele olha o haitiano como um ser humano igualzinho, só que um cara que está mais necessitado. Mas nunca com um olhar de superioridade. Coisa que muitas vezes o europeu e o americano não conseguem esconder no seu olhar. Então isso eu vejo aqui, como já vi na Libéria, como já vi em outras missões da ONU, entendeu? Ajudar, ajudam, mas sempre com aquele ar de superioridade. E quem é ajudado, eles têm um orgulho. Ah, isso então é uma característica importante do haitiano, eles têm um orgulho do Haiti e um orgulho próprio muito grande (...) E uma das coisas que o líder local pediu, e ele reconheceu que o brasileiro não fazia isso, era pra ONU parar de doar comida jogando no chão. Está no relatório aqui do nosso DOP. O líder pediu pra não fazer isso. Né, pra entregar na mão, mas não jogando no chão pras crianças correrem e pegarem. Então você veja, eu quero ser ajudado. Mas eu quero ser ajudado como ser humano. E isso o brasileiro... ele fez questão de destacar, ele falou: eu nunca vi um brasileiro fazer isso, eu estou pedindo é pra outras situações aí, outro pessoal da ONU, civis também etc.

No escritório de informações da MINUSTAH (MPIO), entende-se que tal segredo brasileiro é racializado, conforme indicado pela colocação do tenente-

\footnotetext{
${ }^{243}$ A resposta do tenente-coronel do MPIO reproduz o mesmo olhar que celebra a docilidade de pessoas em posição subalterna: "Olha, eu tenho percebido que é um povo de coração muito bom, sabe? Tem muita gente, muita gente de coração bom. Você vê na expressão as vezes das pessoas que são pessoas puras, assim sabe? Então isso eu sinto muito. Assim, eles me passam muito isso. Os poucos contatos que a gente tem com alguns empregados e tudo, muito simpáticos! Essa é a impressão que eu tenho. De um povo muito bom, muito carismático, de bom coração".
} 
coronel da FAB sobre as semelhanças entre Brasil e Haiti. ${ }^{244}$ Este entrevistado enfatiza o motivo pelo qual os brasileiros estão mais aptos a desempenhar a missão de pacificação em locais como o Haiti, marcados por sua negritude neste tipo de discurso, que equipara africanos e negros a escravos, com naturalidade, repetindo o expediente ativado por Mendonça (2017, p. 61), visto acima.

\begin{abstract}
A gente vê que aqui tem muito, assim, tem muito uma cultura africana, uma cultura um pouco negra, uma cultura um pouco africana, porque a maioria da população aqui é de origem africana, é de origem escrava no passado, de origem negra. Que é uma coisa que a gente também tem muito no Brasil. O Brasil tem muito isso na sua história. Uma boa parte da população do Brasil é de origem africana. Então a gente vê um pouco dessa semelhança né? Isso daí.
\end{abstract}

$\mathrm{Na}$ entrevista com o policial brasileiro integrante da MINUSTAH, as ontologias da alteridade reaparecem. Cumpre notar que se trata de um profissional cuja inteligência e boa formação transparece de imediato. Seu discurso é mais cauteloso que o do subcomandante do BRABAT ou do representante do MPIO. Entretanto, ainda que se esquive de fazer afirmações grandiloquentes, sua fala vai aos poucos revelando os mesmos expedientes discursivos que enfatizam as diferenças entre Brasil e Haiti. Inicialmente, o entrevistado busca surpreender, ao inverter (aparentemente) os termos da contraposição hierárquica quando o tema é (in)segurança pública. "Ao meu ver, a situação no Brasil, no meu ponto de vista, ainda é bem mais grave". Mas nada falou sobre a inexistência de uma missão de estabilização em seu próprio país, dada essa gravidade maior.

As ontologias de alteridade ficam nítidas quando o policial responde diretamente sobre aquilo que percebe como maiores semelhanças e diferenças entre Brasil e Haiti. Sem a mesma engenhosidade do início da entrevista (até se confundindo quanto ao seu papel funcional ao colocar-se na posição de "turista") o entrevistado identifica uma "hostilidade" dos haitianos em relação aos estrangeiros.

\footnotetext{
${ }^{244} \mathrm{Na}$ literatura acadêmica também há formulações sobre o segredo brasileiro em tais cenários. Vinicius de Carvalho (2017) argumenta que a "arma secreta brasileira nas operações de paz" é um "diferencial cultural comum entre os soldados brasileiros que os colocam em situação privilegiada quando na necessidade de resolver situações de conflito, ou de evitar estas mesmas situações. Um suposto 'jeito brasileiro de fazer operações de paz' foi sempre muito relacionado ao aspecto cultural. Sem dúvida que a música é uma das ferramentas para esse diferencial cultural. Se entendermos isso sistemicamente, doutrinariamente, e não apenas como fornecedor de anedotas, poderemos perceber que operações de peacekeeping, peacebuilding e de peace enforcement não podem negligenciar este elemento. Difícil é, e talvez até impossível, ensinar isso a quem não o tem na sua essência e identidade" (2017, p. 49).
} 
Em seguida, o que haveria de comum com o Brasil, para ele, seria apenas a "beleza natural" (também destacada pelo tenente-coronel do MPIO).

Bom, quando eu cheguei na missão eu estranhei um pouco sobre a receptividade da população local, que não é igual no Brasil, sob o meu ponto de vista. No Brasil, as pessoas, os brasileiros, eles tendem a acolher mais o turista, o estrangeiro. Aqui eu notei essa diferença, mas temos que ter em mente, em minha opinião, que são mais de 10 anos, eu acredito que 12 anos, de presença estrangeira aqui. Eu não gostaria de ver na minha cidade, Uberlândia, tanques de guerra nas ruas, militares e policiais de outros países, sem eu ter o conhecimento do porquê daquilo. Então muitas pessoas que não tem o conhecimento do porquê da importância da missão, elas desenvolvem um sentimento de hostilidade contra a missão. Então isso foi um aspecto que eu pude notar a diferença daqui com o Brasil.

Agora um outro aspecto que pra mim é positivo, que se assemelha muito, é a beleza natural aqui do país. Tive uma pequena oportunidade de conhecer um pouco. A paisagem aqui, o meio ambiente é maravilhoso. Pra começar estamos no Caribe. É maravilhoso. Não só o mar, mas os rios, as montanhas aqui são fantásticas.

O policial revela que não possui experiência empírica própria que embase a impressão negativa sobre os haitianos e sua suposta "hostilidade" em relação aos "turistas" e "estrangeiros" em geral. Ao ser questionado se já sofreu ou presenciou algum momento dessa hostilidade com relação à presença estrangeira aqui, o entrevistado admite que "não". Sua impressão, deste modo, é puramente imaginária e, conforme suas próprias palavras, relacional ao que subentende como a maneira mais cordial, ao "jeito do brasileiro", inclusive de seus policiais militares, (notoriamente identificados mundo afora por sua brutalidade e letalidade). ${ }^{245}$

Não, a gente pode notar, quando a gente faz uma análise paralela, ao jeito do brasileiro, do policial brasileiro também, poder te recepcionar, a gente nota no contato diário com as pessoas, com a população local e também conversando com outras pessoas que já passaram por essas situações.

Aparentando desconforto com sua própria enunciação, o entrevistado volta a retrair-se quando solicitado a destacar a maior qualidade e o pior defeito dos haitianos. Em tom enigmático, ele se abstém de responder a ambas as perguntas.

\footnotetext{
${ }^{245}$ Por exemplo, em 2012, o Conselho de Direitos Humanos das Naç̃es Unidas fez uma série de recomendações (total de 170) ao Governo Brasileiro para diminuir a violência policial e as execuções extrajudiciais no país. Uma delas recomendava o fim das Polícias Militares (PMs) brasileiras. Ver (acesso em agosto de 2018): http://g1.globo.com/mundo/noticia/2012/05/paises-daonu-recomendam-fim-da-policia-militar-no-brasil.html.

As Nações Unidas acrescentaram uma nota de esclarecimento que informava que a posição do Conselho de Direitos Humanos era composta por sugestões advindas de todos os seus membros e que este ponto sobre o fim das PMs havia sido feito pela Dinamarca e não representava, necessariamente, a unanimidade daquele fórum. Ver (acesso em agosto de 2018): https://nacoesunidas.org/a-onu-nao-recomenda-o-fim-da-policia-militar-no-brasil/.
} 
Seu silêncio, no entanto, dá mostras daquilo que pretende omitir: a falta de qualidades dignas de menção e a gravidade dos defeitos que desejaria apontar. "Por ser honesto" (de fato o é), o policial prefere calar-se. Um silêncio que indica o poder de produzir uma História sobre do Haiti (TROUILLOT, 1995). ${ }^{246}$

[Na sua opinião, qual é a maior qualidade dos haitianos?]

- silêncio -

[E em seguida eu vou te perguntar o pior defeito]

Pô, é complicado. Eu vou ter que pensar mais um pouco. Eu te respondo no final. A questão da qualidade dos haitianos. Não que eles não tenham, tem muitas.

[Qual que você destacaria?]

Complicado eu também abordar o defeito e uma qualidade, porque depende do ponto de vista. Há defeitos que pra nós são defeitos, mas que para eles talvez sejam qualidades. E vice-versa. Então, se o senhor não se importar, eu vou me abster de citar esse defeito do haitiano.

Agora a qualidade... É, eu também vou me abster. Desculpa, eu não vou citar não. Por ser honesto, então eu prefiro não falar. Eu poderia citar muitas coisas aqui mas eu não estaria sendo honesto.

A "racionalidade específica" da colonialidade do poder é o "eurocentrismo"

(QUIJANO, 2005, p. 227). Esta racionalidade fica expressa de maneira exemplar na resposta que o policial brasileiro fornece quando questionado, logo em seguida, se o Haiti faz parte da civilização ocidental. Sua fala explicitamente exclui o Haiti do ocidente e da civilização, novamente trazendo a geografia como única exceção às suas ontologias da diferença:

No contexto geográfico, sim. No contexto econômico, político, cultural eu acho que ainda carece de alguns patamares para poder atingir a população ocidental. Acho que não faz parte ainda. No termo geográfico sim, mas no termo da palavra, esqueci o termo da língua portuguesa, no termo figurativo, eu acho que não, não faz parte ainda.

Tais "patamares" são típicos da "epistemologia colonial e sua nomenclatura" (GROVOGUI, 2006, p. 33) e referem-se às noções de etapas de desenvolvimento humano (MASLOW, 1943) ou social presentes nas teorias da modernização econômica (ROSTOW, 1961) e política (HUNTINGTON, 1968; LIPSET, 1959), que serão analisadas mais detidamente na próxima seção. Aqui,

\footnotetext{
${ }^{246}$ Para uma visão crítica ("truncada") da modernidade que baseia-se metodologicamente sobre "fragmentos sintomáticos" que giram "em torno de silêncios" e o que "não é dito" sobre o Haiti, ver Fischer (2004, p. 1-38). Para uma discussão construtivista sobre a invisibilidade da raça na teoria de RI que introduz conceitos sobre "silêncio e evasão", resultantes de uma "norma contra notar-se [o racismo]" que os próprios construtivistas seguiriam, ver Vitalis (2000, p. 333-337). Sobre "amnésia" e "abstração" nos estudos internacionais frente à problemática da raça, ver Krishna (2006, p. 89108).
} 
servem para ilustrar ontologias da alteridade que perpassam seu discurso. ${ }^{247}$ São dois tropos - da diferença e da modernização - que aparecem ligados na construção da modernidade (BLANEY; INAYATULLAH, 2004). Mais adiante, ele agrega uma dimensão de força/fraqueza ao rol de comparações hierarquizantes que inferiorizam o Haiti e os haitianos. Apesar de considerar o termo "Estado falido" como "impregnado de preconceito, de estereótipo", ele considera os haitianos como "mais fracos" do que os brasileiros, algo que confere à sua tarefa um tom abertamente missionário.

Eu acho que a nossa missão é de poder as vezes fazer parte dos países que são mais desenvolvidos, e eu vou citar até o Brasil, porque o Brasil é bem mais desenvolvido do que o Haiti. É, justamente, a gente recebeu durante a nossa história, e a nossa obrigação é poder ajudar nossos irmãos mais fracos. ${ }^{248}$

Outra diferença captada pelo olhar do policial brasileiro diz respeito à formação social haitiana, que possuiria uma estrutura de classes mais simples do que a brasileira. Além de fazer recordar dos alertas de Said (2003) quanto à autoridade discursiva sobre o Outro, o entrevistado também incorre no expediente descrito por Sabaratnam (2013) como by-pass de sujeitos políticos locais, ao negar existência de uma classe média haitiana (que não apenas existe, segundo vozes locais, como é politicamente ativa, por sinal). ${ }^{249}$ "O que acontece é que aqui é um pouco diferente do nosso país", explica. "Por que lá a gente enxerga uma classe média. Na minha opinião aqui não tem uma classe média, como existe no Brasil”".

As ontologias de alteridade também são constitutivas de olhares diplomáticos brasileiros sobre o Haiti. O vice-cônsul do Brasil em Porto Príncipe é outra voz que recorre a este expediente discursivo em sua entrevista. Desde antes da primeira pergunta o diplomata informa sobre uma classificação hierárquica entre

\footnotetext{
${ }^{247}$ Para uma crítica das teorias da modernização que as entendem como antecessoras intelectuais e políticas das agendas de state building típicas da paz liberal, ver Bhuta (2008, p. 529-532). Para uma abordagem pós-colonial das teorias da modernização, que aponta linhagem similar, ver Krishna (2009, p. 7-30).

${ }^{248}$ Esta dupla-noção, de dádiva/dever, conhecida como Fardo do Homem Branco, foi trazida pelo policial em termos que remetem à crítica pós-colonial de Grovogui (2006), que diz: "The belief that the West has been blessed with good kings, laws, and reason, while others have not, has intensified and ebbed according to shifting conjectures of power and ideology, including understandings of 'race', 'religions', 'custom' and 'civilization'” (2006, p. 32).

${ }^{249}$ Ulysse $(2015$, p. 55) informa que $12 \%$ da população haitiana pertenceria à uma classe média.
} 
os países, feita pelo Ministério das Relações Exteriores. Nesta ontologia, o Haiti é um "posto de sacrifício", enquanto os EUA são apresentados como um prêmio. ${ }^{250}$

$\mathrm{O}$ vice-cônsul brasileiro fornece uma série de exemplos deste expediente discursivo que produz uma entidade a partir da contraposição binária com outra. Algo também ativado quando o entrevistado tenta apresentar a única semelhança entre Brasil e Haiti, versando sobre as relações raciais e sociais que os dois espaços compartilhariam, como também fizera o tenente-coronel do MPIO. Esta única exceção afirma a alteridade, em vez de negá-la, pois o subtexto de sua resposta informa que em todo o resto o Brasil é superior e, portanto, diferente do Haiti, menos na "liberdade na miséria" de corpos descritos como negros. Vale ressaltar que a pergunta era justamente sobre a maior diferença e o entrevistado respondeu somente sobre semelhanças, em um aparente ato-falho, sintomático deste regime discursivo:

Eu acho que o Haiti e o Brasil têm em comum a herança de miséria deixada, legado europeu. O europeu quis explorar o Brasil e explorou, e enfim... Até é dito numa letra, de uma canção, um samba eternizado na voz do querido Jamelão: o negro vive na senzala e hoje vive livre na miséria da favela, né? Essa liberdade na miséria aqui eu acho que são os pontos que a gente encontra em comum entre o Haiti e o Brasil.

(...) A miséria eu acho que é o grande laço cultural e social que foi herdado dos europeus e que têm em comum. É engraçado, porque às vezes você anda em certas ruas aqui em Porto Príncipe ou mesmo quando você vai um pouco mais pro interior, a impressão que eu tenho é que eu tô em algum pedaço do Brasil, sabe? É incrível como é que... É um legado que se construiu aí além-mar, né? É ultra fora dos continentes, né, impressionante como é que o europeu, ele conseguiu, assim, romper, mas conseguiu ferrar mesmo... Eu observo isso, também, eu estive na África também e vejo que são traços, assim, herdados por nós, sabe? Impressionante!

O recurso a comparações com a África não surpreende, pois o entrevistado informou que já havia trabalhado em países daquele continente. No entanto, segue sendo representativo da colonialidade do olhar que busca, mesmo que instintivamente, comparar o Haiti com tais países em virtude da herança entendida em termos de sua negritude e sujeição frente ao colonialismo europeu. ${ }^{251}$ Em outra

250 "No Itamaraty existe uma coisa chamada remoção casada. Você vem com posto de sacrifício, fica 2 anos e depois você vai pra onde você quiser no mundo. Eu como tenho muita curiosidade, já conheço uma boa parte do mundo, não conheço os Estados Unidos, eu optei pra ir para os Estados Unidos", esclarece o vice-cônsul a este respeito.

${ }^{251}$ Sobre a "projeção da África como o contraponto da Europa e da civilização", ver Grovogui (2006), que afirma: "From the sixteenth onward, Africa firmly became the land of heathens, "black", and the symbol of international dysfunction: a land without laws, without kings, without faiths (...) 
oportunidade, o Haiti é novamente comparado a "países na África" e também ao Brasil. Novamente, este ímpeto comparativo serve à construção de entidades hierarquicamente dispostas (GROVOGUI, 2006, p. 32). Nesta ocasião, a diferenciação é feita em nome de perspectiva de futuro mediante metáforas de luz e escuridão.

Mas assim, em todas as nossas dificuldades no Brasil, com toda essa crise, a gente ainda tem uma perspectiva de melhora. Por mais distante, por mais que a luz esteja no fim do túnel, a gente tem isso, no Brasil. E eu vejo isso também em alguns países na África. E eu não vejo isso aqui, sabe, eu não vejo aqui a luz no fim do túnel. A falta de perspectiva é total.

(...) Então por aí você vê o que eu estou te falando, a falta de perspectiva aqui é muito grande. Eu não vejo como eu te disse, essa luz no fim do túnel, sabe?252

A operação discursiva que produz diferenças marcantes também é realizada por meio de demarcações temporais, que ajudam a transmitir o efeito semântico desejado. Assim como nos discursos sobre caos e ordem, o medo branco volta a ser o tema de fundo. E para explicá-lo, uma comparação espaço-temporal entre Porto Príncipe e o Rio de Janeiro, na qual a cidade brasileira aparece como um local onde determinados tipos de violência - por exemplo, contra a mulher - não seriam tão graves como no Haiti. ${ }^{253}$

Eu te confesso que eu tenho medo de sair à noite. Sete horas da noite aqui pra mim, não sei corresponde a, sei lá, uma hora bem tarde no Brasil. Tipo, não sei, Rio de Janeiro depois das dez horas da noite, onze horas, meia noite você não sai. Aqui eu já sinto medo quando escurece, sabe, eu não me arrisco a ir ao mercado, andar a pé. A minha mulher, por exemplo, ela não gosta de sair pra andar a pé, fazer caminhada, porque o pessoal aqui quando passa de carro, mesmo eu estando do lado dela eles mexem, falam gracinhas, enfim, seguem. As mulheres aqui são bem... As mulheres brasileiras, o pessoal do corpo diplomático, raríssimo elas dirigirem. E tem carteira, sabem dirigir e tudo, mas não pegam porque têm medo.

In contrast, the "West" became "white" and came to exemplify cultural adaptability, political competency, and ethical versatility. Related narratives are implicated in discourses and doctrines of subjects, rights and justice" (2006, p. 32).

252 Interessante notar que mais de uma década antes, em 2006, o chanceler brasileiro afirmava justamente o contrário. Para o chefe da diplomacia à época "a contribuição do Brasil foi importante para que, hoje, o Haiti tenha uma perspectiva de futuro" (AMORIM, 2006, s/p).

${ }^{253}$ O Brasil é, segundo a Organização Mundial da Saúde, o quinto país que mais comete feminicídios per capta no mundo (atrás de El Salvador, Colômbia, Guatemala e Rússia) e um dos que mais promove a violência contra a mulher. O Haiti não está nem entre os dez mais violentos do mundo em termos de gênero, de acordo com as Nações Unidas. Ver (acesso em agosto de 2018): https://nacoesunidas.org/onu-feminicidio-brasil-quinto-maior-mundo-diretrizes-nacionais-buscamsolucao/. No Brasil, ao longo de 2017, ano das entrevistas, uma mulher foi assassinada a cada duas horas e, em média, 135 foram vítimas de violência sexual (estupro) a cada dia, sem contar a subnotificação frequente neste tipo de crime. Ver (acesso em agosto de 2018):

https://www1.folha.uol.com.br/cotidiano/2017/10/1931609-brasil-registrou-135-estupros-e-12assassinatos-de-mulheres-por-dia-em-2016.shtml. 
O trânsito é muito louco e tem medo de ataque mesmo, sabe? Porque eles veem uma mulher branca, cara, sabe, dá medo. Eu faço tudo que eu tenho que fazer durante o dia.

$\mathrm{O}$ entrevistado segue avançando em visões homogeneizantes e estereotípicas sobre "o haitiano", reveladoras de certa colonialidade de seu olhar e do seu medo branco. Ao responder sobre os motivos que levaram o Conselho de Segurança da ONU a declarar o Haiti como ameaça ao seu entorno regional, o diplomata lança mão de expedientes narrativos sobre a excepcionalidade do Haiti. Tal prática já fora denunciada por Yarimar Bonilla (2013) e Michel-Rolph Trouillot (1990), que entendem a insistência na suposta excepcionalidade haitiana como um modo de forçar o esquecimento sobre o "mais longo experimento neocolonial na história do Ocidente" (TROUILLOT, 1990 citado por BONILLA, 2013, p. 153). ${ }^{254}$

Sinceramente eu não percebo esse risco pra região de conflitos aqui, porque o que eu percebo e aí se você for na República Dominicana, que é parte da mesma ilha, eles têm total aversão ao haitiano, né? Não sei, o haitiano, ele não é bem visto na região, sabe? Ele, eu acho que ele também... te falando também outra realidade. O imigrante mais problemático, né, que tem nos Estados Unidos, especificamente em Miami, é o haitiano. Ele é o cara mais isolado, porque é o mais difícil de lidar. Pra você ter uma ideia eu fiquei sabendo que o bairro haitiano que se tem em Miami, ninguém entra lá, só haitiano! Então é complicado, eu não vejo.

Logo adiante, entretanto, o vice-cônsul parece negar as visões excepcionalistas sobre os haitianos, respondendo que sua principal qualidade é que "são simpáticos" (como fizeram, antes deles, o coronel do BRABAT e o tenentecoronel do MPIO). Seguindo esta linha, o entrevistado agrega que ao contrário da Jamaica, onde existiria "racismo às avessas", no Haiti ele não vê isso. "Eles sempre tratam com muita cordialidade o brasileiro". O brasileiro é identificado como branco, portanto. Interessante notar que quando perguntado sobre o que os brasileiros mais poderiam ensinar aos haitianos, o diplomata responderia, mais

\footnotetext{
254 “Trouillot argues that these representations obscure Haiti's place in the world, casting it beyond the realm of analysis and comparison: 'When we are being told over and again that Haiti is unique, bizarre, unnatural, odd, queer, freakish, or grotesque, we are also being told, in varying degrees, that it is unnatural, erratic, and therefore unexplainable. We are being told that Haiti is so special that modes of investigation applicable to other societies are not relevant here'. Trouillot suggest that there are 'hidden agendas' - both intellectual and political - that underlie and are contingent on the various claims to Haiti's uniqueness. Exceptionalism, he argues, serves as a shield to mask the global processes and historical agents that have forged Haitian history: 'The more Haiti appears weird, the easier it is to forget that it represents the longest neocolonial experiment in the history of the West" (BONILLA, 2013, p. 152-153). A expressão mais conhecida deste argumento excepcionalista sobre o Haiti é feita por Samuel Huntington, que classifica o país como "kinless country", ou seja, não pertencente a "nenhuma das grandes civilizações mundiais" (HUNTINGTON citado por FISCHER, 2004, p. 7).
} 
adiante: "Eu acho que a cordialidade". Algo que segundo sua própria fala eles já possuiriam.

De qualquer modo, esta atitude cordial em relação aos brasileiros adviria do reconhecimento da força e da autoridade das armas, mesclado com a criatividade da diplomacia esportiva brasileira, junção analisada por Viana (2009, p. 32-34). Tal união entre consenso e coerção vai ao encontro das perspectivas gramscianas sobre as intervenções da paz liberal, como a de Taylor (2008), que ajuda a entender esta fusão, numa mesma resposta, de elementos aparentemente díspares. "Eles sempre tratam com muita admiração, essa coisa do futebol, né? Por eles terem consciência que o maior contingente de militares da MINUSTAH é de brasileiros, né?”. 255

Em seguida, o entrevistado faz longa digressão sobre a cultura haitiana percebida sob lentes exteriores e superiores, cujo olhar cria sua própria autoridade em concomitância com a explicação do Outro, conforme já alertado por Said (2003) e Spivak (1988). Vale lembrar que sua resposta deveria ser sobre a maior qualidade dos haitianos e haitianas, mas terminou como forte crítica (permeada por machismo) aos supostos defeitos da cultura de mendicância dos habitantes locais.

Por todo um, sei lá, toda essa vamos dizer, essa irmandade africana, que eles têm consciência que tem no Brasil também, né? Eu nunca fui agredido verbalmente ou em gesto, nada a partir de um haitiano. Mas assim, é aquela coisa, também, é o tipo da coisa que você não pode abrir muito, né, porque se você abrir muito daqui a pouco ele está te pedindo dinheiro. Aqui, a menina que trabalha aqui, que é recepcionista aqui no prédio, volta e meia ela pede dinheiro pra gente. É uma coisa, parece que é parte da cultura. Pedir dinheiro pra quem você não conhece. Fato interessante quando você conhece alguém. Os meninos que trabalham no meu prédio, que cuidam da faxina, isso é da cultura haitiana, né? Quando é aniversário deles, eles chegam pra você e falam: hoje é o meu aniversário. Mas assim, hoje é meu aniversário, assim: você vai me dar um presente? $\mathrm{Eu}$, quando cheguei aqui eu fui abordado por um motorista de uma diplomata. Ele é haitiano, o motorista. Só pelo fato de eu dar bom-dia todo dia, né? Ele chegou uma vez e me pediu: hoje é meu aniversário. Aí eu brincando com ele assim e cortando ao mesmo tempo eu falei: olha, no Brasil a gente tem hábito de dar presente só pra mulher! (risos) Mas, assim, é cultural deles, é normal isso. Não é visto como vergonha ou como algo louvável, é cultural.

\footnotetext{
${ }^{255}$ A respeito do 'Jogo da Paz', ver: Viana (2009, p. 32-34). Em 18/08/2004, quatro meses após a instalação da MINUSTAH, o governo brasileiro decidiu realizar um amistoso entre o Brasil e Haiti em Porto Príncipe, como modo de legitimar a intervenção. A descrição oficial deste episódio pela Confederação Brasileira de Futebol (CBF) destaca a contraposição entre a pobreza haitiana e o sucesso brasileiro, além do elo racial entre ambos países, hierarquicamente dispostos ("eles veem nos atletas negros do Brasil um exemplo de sucesso"). Ver (acesso em agosto de 2018): https://www.cbf.com.br/selecao-brasileira/torcedor/jogos-inesqueciveis/em-porto-principe.
} 
A reflexão cultural, ou culturalista, sobre o Haiti permanece até o fim da entrevista com o vice-cônsul, que incorpora assim a postura da "guerra culturalmente sensível" estudada por Maja Zehfuss (2012, p. 175-190). ${ }^{256}$ Ao responder à última pergunta, que versava sobre Haitianismo, o entrevistado novamente embarca em uma enunciação particular daquilo que percebe como traços característicos do Outro haitiano, construído a partir de um $E u$, identificado por "estrangeiros", de acordo com esta percepção, carregada de colonialidade. O diplomata admite que não vê "de outra maneira" o Haitianismo senão por este enfoque cultural, descrito em termos folclóricos que remetem à "admiração curiosa" descrita por Grovogui (2006, p. 29).

Haitianismo? Eu vejo de 2 maneiras: é uma tentativa de, sei lá, de sobrevivência cultural e política. Uma maneira que os haitianos têm, de alguma forma se inserir no contexto, lá no contexto mundial. Você poderia perceber essa coisa do haitianismo. Eu to entendendo a tua pergunta de uma maneira, muito, de uma forma muito cultural. Eu sinto esse haitianismo, por exemplo, quando eu vou aqui pra uma praia, um clube. Inclusive o melhor clube, uma melhor praia, um melhor clube da região, que se chama Decameron. E ali, apesar de ser um lugar frequentado muito pelos estrangeiros e pela elite local, você percebe nitidamente ali essa coisa do haitianismo de se promover... a cultura, a dança, a música, a comida, a culinária do Haiti! Você sente isso nesse clube, né? Dos artesanatos que são vendidos, os quadros que são pintados. Eu sinto o haitianismo, eu vejo por esse aspecto: artesanal, cultural, musical, artístico. Não vejo de outra maneira, sabe?

Houve outras enunciações de posicionamentos de sujeitos que mobilizaram ontologias da diferença ao longo das entrevistas feitas no trabalho de campo. Estas, no entanto, já parecem suficientes para demonstrar o ponto em questão, assim como a colonialidade que lhe é constitutiva. ${ }^{257}$ A próxima seção finaliza a análise das entrevistas com a apresentação dos enunciados que articulam estas diferenças, decerto hierarquizadas, em termos de temporalidade evolutiva linear.

\footnotetext{
${ }^{256}$ Em sua consideração final, após encerradas as perguntas, o vice-cônsul afirmou possuir "muita sensibilidade para perceber a cultura dos países" em que viveu, "e aqui no Haiti não seria diferente". No entanto, sua fala parece mais afeita aos "apelos por clichês raciais (ou étnicos) e versões supersimplificadas de cultura" aludidas por Grovogui (2006, p. 32). Por sua vez, Zehfuss (2012) alerta para o uso da antropologia como instrumento para aumentar a eficiência do militarismo norteamericano em operações no Sul global, mediante um melhor conhecimento da "cultura" local. Para uma abordagem que reivindica o "culturalismo" como um conhecimento que "abre espaço para que o campo da liderança opere de modo consistente nas missões de paz", ver Clauhs (2013, p. 99).

${ }^{257}$ Para uma discussão de fôlego sobre a construção de alteridades (Self/Other) entre Brasil e Haiti no âmbito da MINUSTAH, deve-se consultar também o trabalho de Maíra Gomes (2014), que aborda a questão a partir de uma mirada teórica pós-estruturalista.
} 


\section{Teleologias de modernização e amadurecimento do Outro}

Contrariando as percepções de Fischer (2004), James (1989), Genovese (1979), Mintz (1993), Munro e Shilliam (2011), Seguy (2014), Peck (2016), Porto-Gonçalves (2006) e Scott (2004) acerca da modernidade haitiana, ${ }^{258}$ sob muitos aspectos pioneira e anterior ao que é celebrado como indicativo da modernidade em outras partes (Estado nacional soberano; relações capitalistas de propriedade; direitos individuais, começando pela abolição do trabalho escravo; igualdade jurídica e racial; ideologia nacionalista), as vozes brasileiras sobre o Haiti trazem constantes imagens de arcaísmo, infantilidade ou subdesenvolvimento (político, econômico, sociocultural) que colocam o Haiti como temporalmente mais atrasado nas etapas implicitamente sugeridas em discursos que pregam a modernização, amadurecimento ou desenvolvimento do país e seus habitantes como solução para os problemas descritos. ${ }^{259}$

Ao fazê-lo, tais narrativas reproduzem a versão eurocêntrica da modernidade que esconde a colonialidade e a diferença colonial como fatores que impedem que tais etapas sejam percorridas linearmente por todas as formações sociais, ao mesmo tempo em que reafirmam este telos como único que deva ser buscado (BLANEY; INAYATULLAH, 2004; ESCOBAR, 1995; 2005; KRISHNA, 2009; QUIJANO, 2000; 2005). Lula da Silva (2014), por exemplo, já falava de um "salto histórico na infraestrutura do país"260 proporcionado pela cooperação para o desenvolvimento provida pelo Brasil, dando mostras deste imaginário etapista. Neste ambiente discursivo, não é raro deparar-se com metáforas que assemelham o Haiti e os haitianos a crianças, ou mesmo a bebês, em faixas etárias iniciais. O papel externo é, neste caso, naturalmente parental, de agentes que cuidam e ajudam a fazer crescer um ente discursivamente produzido como infantil. São imagens e percepções que conformam uma "taxonomia de afeto" ou "economia emocional" que coloca o ocidente como um adulto cuja função é cuidar de não ocidentais, menores de idade e incapazes (GROVOGUI, 2006, p. 34).

\footnotetext{
258 Raoul Peck (2016) é peremptório ao afirmar: "nosotros somos los que hemos inventado la modernidad!” (2016, p. 25), em resposta às considerações de Seitenfus (2016) sobre o tema. PortoGonçalves (2006) exclama que "somos modernos há 500 anos!” (2006, p. 153).

${ }^{259}$ Sobre a "modernidade colonial" e os discursos "da tradição teleológica" que diminuem ou negam as soberanias e comunidades políticas extra-européias como pré-modernas, ver Aching (2011, p. 2934). Sobre os discursos trataram como anômalas as formas de soberania existentes no Haiti e no Caribe, ver Bonilla (2013) e Trouillot (1990).

${ }^{260} \mathrm{~s} / \mathrm{p}$., itálico adicionado.
} 
O subcomandante do BRABAT apresenta uma dessas metáforas, de maneira sutil. "Você vê que a ONU entrou aqui, apesar da situação ainda da falta de recursos, instituições ainda começando a caminhar... é muito melhor do que 2004."261 Esta comparação subliminar com seres humanos em idade inicial é reiterada pelo tenente-coronel do MPIO, que transmite como natural a função parental de cuidado exercida pela MINUSTAH. "Então, o que obviamente se vê é que ela está presente até hoje porque ainda não se conseguiu ter essa certeza que está tudo estabilizado", antes de completar: "O país tem que ter condições de cuidar de si mesmo". ${ }^{262}$ Algo que o Haiti não pode ter neste regime bélico-discursivo.

Advérbios de tempo como ainda são frequentes em tais expedientes narrativos. ${ }^{263}$ Eles ajudam a produzir o efeito semântico de uma temporalidade em andamento, de um processo em execução, mas que ainda não atingiu o telos préestabelecido pelo próprio discurso modernizante. Esta diferença temporal, etapista, também pode ser entendida como uma ontologia da alteridade no sentido dado por Sabaratnam (2013) em sua crítica aos discursos envolvidos com a paz liberal. Trata-se, assim, de outro modo de articular o eurocentrismo e a colonialidade mediante discursos que enfatizam diferenças frente ao Outro haitiano, tido como mais atrasado ou jovem do que o Brasil e demais países "de primeiro mundo" que encabeçam as missões de paz multilaterais. O etapismo característico de tais teleologias é perceptível na entrevista com o subcomandante do BRABAT, que tenta explicar o lugar do Brasil nesta escala evolutiva. Uma que ordena e classifica os países dentro do cenário internacional. A posição de cada país pode variar, mas a colonialidade do saber (Lander, 2005), que oferece uma chave de entendimento para as diferenciações, permanece.

Então, o Brasil deixa de ser um país vaca de presépio na hora das votações e ele já está numa posição intermediária, entre aqueles países que decidem e aqueles que concordam. Então o Brasil as vezes tem um destaque maior, as vezes menor, mas ele já conseguiu sair da massa. ${ }^{264}$

\footnotetext{
${ }^{261}$ Itálico adicionado.

262 Itálico adicionado.

${ }^{263}$ Seguy (2015, p. 155) comenta sobre o uso da palavra "ainda" nos discursos modernos/coloniais.

${ }^{264}$ Itálico adicionado.
} 
Assim, ao contrário dos países como o Haiti, que são desprovidos de agência internacional, o Brasil, no discurso do subcomandante, recebeu a "oportunidade de liderar o componente naval de uma missão que foi sempre eminentemente européia, que foi a UNIFIL no Líbano". Sob esta ótica, o importante a ser destacado é a "capacidade brasileira" (frente à incapacidade haitiana) de atuar no ambiente multilateral e obter uma "posição intermediária", próxima dos europeus. ${ }^{265}$

Até autores hipercríticos à MINUSTAH, como Seitenfus (2016), reproduzem este imaginário em que o Haiti possuiria um grande atraso ou uma suposta inadaptabilidade constante à modernidade. Do outro lado - ou mais adiante na escala temporal modernizante - o "Brasil já conseguiu sair da massa" e teria como "ganho maior" em sua participação na MINUSTAH "esse ganho da gente estar se mostrando". Mostrando, portanto, a modernidade brasileira frente ao arcaísmo haitiano. "Isso, como eu te falei, tem reflexos em todas as áreas, inclusive no campo econômico". Para o entrevistado, "nunca um brasileiro iria liderar a OMC" sem essa oportunidade conferida pela liderança militar da MINUSTAH: "um poder acaba contribuindo para outro poder", diz sobre o tema. Nesta propagação internacional do poder brasileiro, o discurso do entrevistado omite que todo poder é sempre exercido contra, ou sobre, alguém geralmente descrito como necessitado, beneficiário ou incapaz de resistir a este exercício (FOUCAULT, 2006).

A disparidade temporal entre o Brasil interventor e o Haiti ocupado é indicada pela narrativa de transferência de agência de um país para outro, expressa em termos novamente gradualistas. Quando perguntado diretamente se acreditava que um dia o Haiti poderia alcançar os mesmos níveis de progresso e civilização de outros países das Américas, o subcomandante diz: "I hope so, né. I hope so. Só que você fazer um país funcionar é um processo complexo, como eu falei. As melhoras elas são a conta gotas né. Eu espero que sim”. Não há certeza sobre o sucesso do catch up desenvolvimentista ${ }^{266}$, nem sua duração; contudo sobre as

\footnotetext{
${ }^{265}$ Este tipo de representação estamental, hierárquica, não é exclusividade dos militares, tendo em vista que diplomatas de carreira brasileiros também usam metáforas (no caso, futebolísticas) como "primeira divisão das relações internacionais" em trabalhos sobre a presença do Brasil no Haiti (NASSER, 2012, p. 237).

${ }^{266}$ Para uma crítica da linguagem do catch up desenvolvimentista, ver o livro de Samir Amin [edição original de 1988], autor que é curiosamente ignorado pelas discussões pós-coloniais em voga nas teorias de RI, mas que produziu reflexões similares (por vezes mais profundas) sobre os mesmos temas, muito antes desta abordagem tornar-se moda. Cf. Amin, S. Eurocentrism - Modernity,
} 
aspirações teleológicas subjacentes ao discurso da modernização não existem grandes vacilações. Tal confirmação é expressa, sintomaticamente, via uma estética eurocêntrica (ou seja, em inglês): "I hope so".

O policial brasileiro entrevistado na base da MINUSTAH em Porto Príncipe (Campo Delta) igualmente faz uso de tais teleologias modernizadoras e infantilizações discursivas do Haiti e haitianos, em meio à descrições de saberes e técnicas de governamentalidade. Sua descrição do trabalho realizado enfatiza que se trata de uma transferência de capacidades intelectuais e experiência de controle de populações, ou seja, de "boas práticas policiais", termo repetido por três vezes no início da entrevista. É nítida a ênfase nos papéis de cada entidade binariamente construída, Brasil e Haiti: os primeiros tem a missão de assessorar, ensinar, planejar, ajudar, enfim, "dar um Norte” para aqueles que, como o Haiti, representam o Sul global no imaginário colonial-moderno. Repetindo o hábito eurocêntrico do subcomandante do BRABAT, o policial também inicia sua explicação sobre a relação da MINUSTAH com a Polícia Nacional Haitiana usando termos (desnecessários) em inglês. "Sim, a nossa relação aqui é de mentoring e advising".

\begin{abstract}
Nosso objetivo principal é ajudar na reconstrução da PNH no que tange ao assessoramento e ensino de técnicas, boas práticas policiais, filosofia de polícia comunitária, que a gente traz dos nossos países. (...) Nós podemos apenas assessorar e orientar a PHN, como eles devem agir. Dar um direcionamento para que ela melhore a sua capacidade de atuação no país.

(...) Conforme o tempo for passando eu acredito que com o empenho dos países que fazem parte da MINUSTAH, alcançaremos esse objetivo. Ela ainda carece de muito assessoramento.
\end{abstract}

Esta conclusão é repetida ao longo de sua entrevista, em formatos variados, que convergem no sentido de produzir um Haiti carente do assessoramento externo, especialmente dos recursos intelectuais vindos de lugares tidos como mais desenvolvidos, como o Brasil. Busca-se o "melhoramento das condições", no que tange ao contexto policial, "principalmente da mentalidade da Polícia Nacional Haitiana, que precisa ser melhorada, aperfeiçoada". ${ }^{267}$ Seus contrapartes haitianos são descritos como "aliados", mas "não estão em patamar de igualdade" com os policiais brasileiros, "precisam de ajuda para poder chegar lá". Esta é, em sua

Religion, and Democracy - A Critique of Eurocentrism and Culturalism. New York: Monthly Review Press, 2009 (p. 8; 23; 88; 102; 182; 268; 277).

${ }^{267}$ Itálico adicionado. 
opinião, uma das "dificuldades que tem que ser superadas" pela intervenção modernizadora da MINUSTAH no aparato policial local.

A infantilização do Outro atinge seu paroxismo nos momentos em que o entrevistado afirma - por cinco vezes ao longo da entrevista - que os haitianos são incapazes de "andar com as próprias pernas". Trata-se da produção de um objeto cuja característica distintiva seria sua infância ou fragilidade, ideia que substituiu (ou agregou-se) ao imaginário sobre Estados falidos nos discursos da paz liberal e que cria as condições de possibilidade, ou mesmo a necessidade ética, da intervenção (CHANDLER, 2006; NOGUEIRA, 2014). As perguntas tratavam de desenvolvimento econômico, mas conduziram à colonialidade do saber, expressa na forma de uma insuficiência total do Haiti para produzir a si mesmo.

Questão de desenvolvimento é difícil da gente poder opinar. Mas a gente nota que o país ele é muito dependente do desenvolvimento estrangeiro, de ajuda humanitária, e no meu ponto de vista ele ainda não tem autonomia para andar com as próprias pernas, na questão econômica. Ele carece ainda de um apoio e acompanhamento internacional.

(...) Mas conforme o desenvolvimento do tempo, eu creio sim, eu sou um cara otimista, que ele vai atingir o patamar dos outros países, mas para que cheguemos a isso necessitamos estar ajudando a esta nação, que ainda carece de uma ajuda internacional. Não apenas financeira, mas também assessoramento, na questão de desenvolvimento, nesse sentido.

Esta retórica paternalista é mantida na pergunta seguinte, sobre o que mais faltaria ao Haiti. Novamente a metáfora das pernas, ou melhor, de sua falta, é a que sobressai. Não resta dúvidas que, neste regime discursivo, a menoridade, ou insuficiência, haitiana são incontornáveis:

O que mais falta na minha opinião é uma condição de poder ser independente, de ter autonomia para andar com as próprias pernas. Acho que ainda não chegamos a esse ponto onde o Haiti vai poder, pode, ser autossuficiente. Ele ainda no meu ponto de vista depende ainda da ajuda dos outros. Acho que a partir do momento em que ele atingir essa autossuficiência, e aprender como ele vai andar com as próprias pernas, eu acho que a gente vai ter atingido o objetivo da missão.

O espírito condescendente também é educacional. O entrevistado entende sua tarefa como abertamente professoral, dando mostras de certa pedagogia da modernização, ou pedagogia da civilização, do Outro. "Cada um tem diferenças, de costume principalmente, mas eu creio que nós que somos de outros países temos que passar e ensinar o que há de melhor no jeito de cada um”, explica. E no seu caso específico, aquilo que os policiais brasileiros podem ensinar aos haitianos está 
diretamente ligado à falta ou deficiência identificada pela ideia de subdesenvolvimento generalizado do Outro, que é referido a partir de suas múltiplas carências. "E [ensinar] práticas policiais, no nosso caso, para essa nação, que ainda carece bastante desse desenvolvimento policial, desenvolvimento econômico, desenvolvimento em vários aspectos". Expressa, assim, a combinação entre o poder da razão pastoral (disciplinar) e da razão governamental (biopolítica), mediante "promessas de salvação" e "dispositivos de segurança" (CASTRO-GÓMEZ, 2006, p. 160).

Esta linha de raciocínio, ou "racionalidade específica" (QUIJANO, 2005, p. 227), prossegue até encontrar uma formulação-síntese que conecta a pobreza particular do Haiti com a missão eminentemente intelectual a ser desempenhada por quem é apresentado como mais desenvolvido. "Mas o maior problema do Haiti não é a pobreza", diz o policial, que emenda: "Pobreza no sentido de fome. Existe uma pobreza aqui maior, que é a pobreza de desenvolvimento. Às vezes da necessidade de uma assessoria estrangeira igual a gente está fazendo". ${ }^{268} \mathrm{Na}$ quarta vez que se utiliza da metáfora etária sobre "andar com as próprias pernas", a fim de representar alegoricamente as insuficiência haitianas, o policial entrevistado chega a confundir-se e, literalmente, troca os pés pelas mãos em seu discurso, mal conseguindo completar seu próprio argumento:

E, a falta também de autonomia industrial. Ele ainda é um país que não consegue andar com as próprias mãos e acaba tem... gerencia, é... uma camada mais rica da população acaba ficando no controle sobre o produto que é... não é produto produzido aqui, mas é o dinheiro que o país arrecada, o orçamento. ${ }^{269}$

Por fim, o etapismo linear da colonialidade do saber fica ainda mais nítido quando o policial entrevistado lança mão de analogias organicistas e cognitivas para, novamente de forma paternal e professoral, referir-se ao desenvolvimento da "inteligência" do Outro. A pergunta era se o Haiti era um Estado falido ou não.

Às vezes no nosso ponto de vista não deu certo. Mas as vezes é o país que pra eles está bom, ou que carece de desenvolvimento, mas que necessita de seu tempo. Assim como uma pessoa tem mais facilidade pra poder se desenvolver em termos de inteligência, de relacionamento com outras pessoas, existem pessoas que tem

\footnotetext{
${ }^{268}$ Itálico adicionado.

${ }^{269}$ Itálico adicionado. A quinta vez que o policial se vale da metáfora fragilizante/infantilizante da falta de pernas é quando defende a continuidade da missão (que seria encerrada oito meses após a entrevista): "Sim, sim. No meu ponto de vista não é o momento de deixar a missão. Porque eles não têm a capacidade ainda de andar com a própria perna", afirma.
} 
mais dificuldade. E não é que essa pessoa é uma pessoa falida e não deu certo. Ela precisa de ajuda.

O vice-cônsul brasileiro em Porto Príncipe, por sua vez, fornece ampla gama de exemplos de mobilização das teleologias da modernização que apresentam o Haiti como arcaico se comparado a espaços como o Brasil, que estaria mais à frente nesta linearidade evolutiva. Tal "perspectiva temporal da história" concebe o Outro como "uma categoria naturalmente diferente", como "inferiores" e "anteriores" (QUIJANO, 2005, p. 238). A comparação com Moçambique serve para enfatizar o quão atrasado estaria o Haiti, especialmente em termos econômicos, pois ainda não teria alcançado nem mesmo a condição de "país em desenvolvimento".

Eu vou... Engraçado eu estive em Moçambique, Maputo. Pobre também, mas em Moçambique eu noto que existe uma coisa, já, uma política desenvolvimentista. Você percebe que eles têm um... É um país em desenvolvimento. E aqui eu não percebo isso. Eu não percebo um traço que, porra... E olha que muito dinheiro é injetado aqui. Já foi e continua sendo. E acho que isso vai pro bolso de alguém. Não tenho a menor dúvida disso.

O diplomata acredita que são os próprios "governantes" haitianos os culpados pela malversação dos fundos "injetados" pela comunidade internacional no país, ecoando os alertas de Chandler (2006) sobre a evasão de responsabilidades típicas dos países promotores da paz liberal. O entrevistado acredita, ademais, que a "democracia ainda não é muito respeitada" no Haiti, indicando que a modernização que o país precisaria seria também política, em sua visão. "Eu acho que o maior exemplo que a gente pode dar no campo político é a coisa da nossa democracia. Que isso possa de alguma forma ser passado para eles”. Desta forma, tanto no âmbito econômico, como no político, o Haiti aparece em seu discurso como ainda fora de seu caminho e inerte. Mais atrasado do que os atrasados, mais jovem que os jovens, mais infantil do que as crianças: "Eu acho que aqui está tudo na fase embrionária ainda. Eu não poderia dizer que é um Estado falido, porque não... Ele não aconteceu de fato ainda, sabe?".270

Assim, transmite-se a ideia de que um tal lugar precisa indubitavelmente da intervenção modernizadora, uma vez que nem faz parte ainda da linha de progresso histórico imaginada pelas teleologias eurocêntricas, sobretudo as de tradição liberal e sua concepção contratualista de Estado. Nelas, o Haiti é situado firmemente em

${ }^{270}$ Itálico adicionado. 
estágio anterior ao contrato social. "Eu acho que quando você fala de Estado falido, Estado fracassado, é porque de alguma forma ele já tentou ou já foi alguma vez um Estado né?". ${ }^{271}$ O Haiti, se deixado a sós, portanto, permanece pré-contratual, estático. Nesta racionalidade familiar aos estudiosos de teoria das RI, somente um Estado soberano, e reconhecido como tal, seria capaz de propiciar a temporalidade evolutiva no âmbito doméstico (Walker, 2013) que, no discurso do entrevistado, faltaria ao Haiti. De acordo com Mignolo (2003), tal negação da contemporaneidade é uma das principais estratégias da colonialidade do poder. ${ }^{272}$

Se em termos políticos a anterioridade Haitiana é suprema, ou excepcional, do ponto de vista econômico o diplomata acredita que é possível estimar uma diferença temporal entre os respectivos níveis de desenvolvimento de Brasil e Haiti. “Ah, a gente bota um chute, assim, um século. Um século tranquilamente. Um século e eu estou sendo otimista". A diferença expressa em termos de temporalidade linear e evolutiva reaparece quando a pergunta é levemente modificada no sentido de questionar se o Haiti um dia alcançará os mesmos níveis de progresso e modernização que os outros países das Américas. Para o vice-cônsul, a resposta é negativa, ainda que o telos modernizante seja reafirmado, justamente como fizera o subcomandante do BRABAT. "Eu acredito que não, mas eu te confesso que é o meu desejo. Eu desejo isso para esse povo". Conforme notado por um investigador descolonial, deve-se estudar "a colonialidade alojada nas próprias estruturas do desejo que um sujeito cultiva e alimenta" (CASTRO-GÓMEZ, 2006, p. 171). A explicação do vice-cônsul recria as ontologias da alteridade trabalhadas na seção anterior, agora sob a roupagem discursiva do desenvolvimento e sua caracterização do Outro como aberração pré-moderna:

Mas assim, eu acho que tá muito longe ainda, né? Você fala assim em progresso tecnológico, é tudo muito rudimentar aqui ainda, né? Eu vou te dar um exemplo: aqui você pode comprar TV $4 \mathrm{k}$, mas a provedora ainda é analógica. E enfim, embora já se tenha aqui na área o que pode-se chamar de tecnologia, é, coisa da fibra ótica, né, computador... Mas assim eu acho que até isso chegar! Por exemplo,

\footnotetext{
${ }^{271}$ Conforme visto no capítulo 2, Seguy (2014) sugere uma visão diametralmente oposta sobre esta metafísica de presença e ausência do Estado moderno no Haiti. O mesmo autor também alerta sobre os discursos franceses (de Victor Hugo a Nicolas Sarkosy) que percebem a África como desprovida de História, até que os Europeus a iniciem (SEGUY, 2015, p. 153-155).

272 "O tempo linear da história universal entrincheirou-se, ademais, na própria ideia de missão civilizadora: ser civilizado é ser moderno e ser moderno significa estar no presente. Assim, a negação da contemporaneidade tornou-se uma das estratégias mais poderosas para a colonialidade do poder na subalternização das línguas, saberes e culturas" (MIGNOLO, 2003, p. 385).
} 
hoje essas tecnologias como são muito mais abrangentes, até o pobre no Brasil tem acesso a essas! Isso aqui ainda é coisa de ficção científica pro haitiano. ${ }^{273}$

A caracterização do Outro haitiano como pré-moderno reaparece, como seria esperado, na pergunta sobre o pior defeito dos habitantes locais. Segundo o entrevistado, uma série de hábitos, que podem ser lidos como exóticos, são visíveis, de modo a sugerir que o ethos de missão civilizadora é de fato integrante das posturas brasileiras sobre o Haiti ocupado (BLANCO; GUERRA, 2017). Os piores defeitos viriam da "cultura deles" e seus comportamentos cotidianos:

Cara, o pior defeito é você andar no trânsito. Eles são terríveis! E o pior defeito eu acho que é isso, é um pouco, né, essa coisa de você querer dinheiro, querer alguma coisa sem conhecer a pessoa! Eu acho um traço terrível da cultura deles, né? Não sei outro defeito, é cultura, por exemplo; chegar e mijar na rua. Eles fazem isso sem cerimônia, pode estar passando uma mulher com criança, eles tiram a calça e mijam na rua onde estiver. Eu acho que esses aí são os 2 defeitos, né? Essa coisa de pedir dinheiro... É isso!

Diante de tal assertiva, não surpreende que o diplomata admire o trabalho das igrejas evangélicas, tanto brasileiras como norte-americanas, atuando no Haiti. "Eles estão aqui com a missão meramente social mesmo de ajudar". Para ele não há "má intenção" nem "picaretagem" envolvendo a atuação de missionários cristãos no país. ${ }^{274}$ "Eu sinto que os brasileiros de ordem religiosa que estão aqui estão

\footnotetext{
${ }^{273}$ Outro aspecto econômico que mostraria o atraso haitiano diria respeito à formação de sua classe dominante, que neste discurso atende ao intento de mostrar que a forma de capitalismo existente no Haiti também seria arcaica, ainda em seu estágio mercantil, ao qual corresponderia o patrimonialismo de sua elite. Ao responder sobe onde estão os ricos no Haiti, o diplomata informa: "Olha, eu acho que a fonte de riqueza aqui, isso aí eu posso te dizer com uma certa propriedade, tá? É o pessoal, vamos dizer assim, a burguesia comercial que no fundo começou seus negócios aqui com capital oriundo de alguma coisa política, de algum cargo político. Só pra você ter uma ideia a academia que eu frequento é do filho do ex-presidente. Então você vê que é um comércio, mas a fonte disso vem da onde? O pai que era o presidente, foi presidente do Haiti." O presidente em questão é Michel Martelly, que governou o país entre 2011 e 2016, com amplo apoio norteamericano e da MINUSTAH.

${ }^{274}$ Diversos casos de escândalos envolvendo missionários cristãos no Haiti já foram denunciados e comprovados. O mais recente a declarar-se culpado foi James Arbaugh, condenado em julho de 2018 a 23 anos de prisão pelo abuso de pelo menos 21 menores de idade durante seu projeto intitulado "Walking Together for Christ Haiti". Meses antes, outro missionário cristão dos EUA, Daniel Pye, recebeu pena de 40 anos de prisão por gerenciar um orfanato em Jacmel, cidade costeira ao sul do Haiti, no qual eram cometidos abusos contra os menores sob custódia. Para mais, ver (acesso Agosto de 2018): http://www.foxnews.com/us/2018/07/24/haiti-missionary-sentenced-to23-years-for-child-sex-abuse.html

Em 2010, o famoso pastor evangélico Pat Robertson fez declarações públicas em seu programa de televisão em que culpava os haitianos pelo terremoto sofrido dias antes. Sua acusação era que os haitianos teriam literalmente feito um pacto com o diabo para derrotarem os franceses durante a guerra de independência. A religiosidade vodu também seria manifestação deste elo com forças diabólicas, que desencadeiam a fúria divida (do Deus cristão) manifesta em termos de catástrofes ambientais e sociais. A adoção do cristianismo neopetencostal seria a única salvação para o país, de acordo com esta visão. Ver, a respeito (acesso agosto de 2018):
} 
dando uma grande contribuição ao quadro social". E, novamente, esta contribuição estrangeira é narrada em termos de melhoramento de traços incivilizados da cultura local. "Em termos de educação, em termos de saúde, de higiene e de bem-estar, sabe? Estão, assim, ensinando mesmo, sabe? Então é messiânica, sabe, a missão”. Impossível ser mais didático que o vice-cônsul.

Logo antes, o entrevistado também respondera afirmativamente à pergunta se o Brasil e a ONU resgataram o Haiti: "Sim, com certeza, com certeza". Afinal, um país tão atrasado e, portanto, inferior aos demais, precisaria da ajuda dos mais maduros. Sua resposta é igualmente afirmativa para a pergunta sobre o Brasil ser uma espécie de irmão para o Haiti. "Sim, justamente por essas coisas que eu te falei, essa irmandade africana, com certeza”. Entre irmãos, contudo, há diferenças de capacidades, inclusive as intelectuais. Ao ser indagado sobre o pertencimento do Haiti à civilização ocidental, ele oferece o seguinte raciocínio, que inclui ao mesmo tempo em que exclui. Não fica nítido como o diplomata encara seu próprio pertencimento àquilo que chama de "visão branco-europeia", parecendo filiar-se ao terceiro espaço teorizado como "in-between" por Homi Bhabha (1996, p. 53) e utilizado como ferramenta metodológica por Moreno et al. (2012, p. 382) para analisar as negociações entre os locais e a presença internacional no Haiti:

\begin{abstract}
Sim, com certeza, né? Apesar de, na visão branco-europeia, vamos dizer assim, eles não terem dado a sua contribuição com a inteligência humana, eu os vejo como parte, sim, né? Eu te digo isso, assim... Não sei, eu posso estar dando exemplos aqui um pouco estapafúrdios, mas por exemplo: eu sou músico também e eu tenho aulas com um professor de guitarra e ele é haitiano. E ele conhece os grandes nomes, grandes guitarristas que eu conheço! E ele conhece as técnicas, de teoria musical e enfim, tudo isso que envolve aí a sutil arte de tocar guitarra e ele tem conhecimento! Eu não sei como ele buscou isso aqui! (...) Quer dizer, como não ver um haitiano como parte de uma civilização ocidental sendo que ele tem todo cabedal teórico. Eu vejo, eu vejo, sim, sabe? Eles não podem ter dado ainda uma grande contribuição para o mundo aí da ciência, enfim, mas eu os vejo como parte integrante, sim!
\end{abstract}

Essa falta de contribuição intelectual ao Ocidente ${ }^{275}$ corresponde à outras faltas, de caráter material, observada pelo diplomata brasileiro. "Não tem sistema

https://www.telegraph.co.uk/news/worldnews/centralamericaandthecaribbean/haiti/6986130/Haitiearthquake-US-televangelist-says-pact-with-devil-cursed-country.html

275 Para uma visão contraria, ver Susan Buck-Morss (2011) sobre a relação entre Hegel e o Haiti. Ver também Joana Gorjão Henriques (2017) que, em discussão similar, se insurge contra o modo "como os africanos e a África são retratados pela História, como sua contribuição é sistematicamente ignorada pelo Ocidente" (2017, p. 12). Franck Seguy (2015) aponta para o mesmo problema da modernidade/colonialidade ao contestar as narrativas sobre a necessidade da Europa para dar início à História na África. 
de esgotos"; "não tem lazer aqui", diz o vice-cônsul, impressionado com o tamanho da falta no Haiti. “A gente vai de vez em quando para uma praia distante. Não tem... não tem nada. Eu não sei como te eu expresso isso em palavras, essa falta de tudo que tem aqui”. O que tem é a falta, nesta narrativa articulada via metafísicas entre presenças e ausências. "As pessoas não têm perspectiva, elas andam pra cima e pra baixo a vagar e passam os dias assim, porque não tem o que fazer, não tem trabalho, não tem nada”. Não tem nada. E, como visto, a pior falta é a de futuro:

Acho que a falta da perspectiva, né? Você pode citar aí, esgoto, casa com chuveiro, geladeira... Isso aí é... mas é a falta de perspectiva, a falta de melhora, falta de você poder... pô, eu vou poder ter um emprego, um trabalho.

(...) A falta de perspectiva eu acho que é uma coisa, é terrível, né, porque você estar numa situação vivenciando um momento, uma crise ou o desemprego, alguma coisa, mas a falta de perspectiva, ela eterniza isso.

Em uma situação assim descrita, pode-se entender o grau de poder que a biodiplomacia (CONSTANTINOU; OPONDO, 2016) brasileira atinge no Haiti, a partir de projetos de cooperação para o desenvolvimento imbricados com as atividades militares e diplomáticas. O discurso do vice-cônsul pode ser lido assim. ${ }^{276}$ Além dele, a mesma autora que apresenta os projetos da cooperação internacional como uma "segunda revolução haitiana" também admite que esta “missão impossível” resultou, principalmente desde o terremoto de 2010, em um "de facto sistema de tutela" (HIRST, 2012, p. 21; 23). ${ }^{277}$ Esta biodiplomacia brasileira ganha ilustrações numéricas, por exemplo, na Revista BRABAT 19, que traz os seguintes indicadores sobre o impacto desta ação multidimensional:

Além da parte de segurança, o BRABAT 19 também realiza diversas ações de caráter humanitário, que vão desde cortes de cabelo para as crianças até a distribuição de água potável. Essas ações são conhecidas pela sigla em inglês

\footnotetext{
${ }^{276}$ De fato, na linha oficial da política externa brasileira para o Haiti, esta fusão tripla foi sempre a pedra angular do discurso sobre a participação destacada na MINUSTAH. O ministro Celso Amorim (que passou pelas pastas de Relações Exteriores e Defesa durante o período da missão), sintetizou assim esta linha: “... procuramos trabalhar simultaneamente em três vertentes interdependentes e igualmente importantes: a manutenção da ordem e da segurança; o diálogo político, com vistas à reconciliação nacional; e a promoção do desenvolvimento econômico e social. Creio que estamos no caminho certo" (AMORIM, 2006, p. 2).

277 Em consonância direta com os três componentes da biodiplomacia identificados por Constantinou e Opondo (2016), defesa, desenvolvimento e diplomacia, ela arremata de modo a defender este modo de cooperação Sul-Sul: "Se no período anterior era por vezes difusa a fronteira entre ações de assistência e de estabilização, nas quais se apoiavam mutuamente técnicos de agências especializadas do governo brasileiro e os contingentes militares, a partir das urgências impostas pela crise humanitária haitiana pós-sismo a sobreposição de tarefas tornou quase impossível diferenciar tarefas de assistência técnica das ações que atendem às necessidades na área de segurança pública" (HIRST, 2012, p. 23).
} 
CIMIC ou Atividades de Cooperação Cívico-Militar ou CIMIC [sic.]. Desde que o BRABAT 19 iniciou suas atividades, já foram realizadas cerca de 1500 CIMICs, que beneficiaram mais de 70 mil pessoas. (BRABAT 19, 2014, p. 48)

Em todo caso, apesar de implicar criticamente o colonialismo europeu, sobretudo o francês, nas mazelas socioeconômicas apontadas por seu discurso sobre o Haiti, o vice-cônsul brasileiro afirma que "não saberia dizer, assim, a fonte de pobreza, a maior fonte de pobreza". Seria uma tarefa árdua demais neste espaço construído discursivamente por sua falta de recursos materiais e intelectuais: "É difícil dizer quando o país todo é muito miserável, né?". Por fim, a colonialidade das vozes políticas brasileiras no Haiti ganha sua expressão mais nítida com o emprego de nova metáfora que infantiliza os haitianos, ao classificá-los como desejosos de "mimos" de seus ex-colonizadores:

Isso aí remonta ao passado, aquela eterna vontade de ser mimado pelo colonizador, no caso aqui o francês, né? Isso aí é percebido não só no mundo, vamos dizer assim, o mundo negro africano. Mas isso aí é percebido em outras culturas. Por exemplo, na cultura árabe você pega o marroquino, o tunisiano e o argelino, eles até hoje querem assim, ser mimado pelo colonizador francês! E isso ocorre aqui também! Ao mesmo tempo que eles têm aversão, eles querem de alguma forma ter algumas benesses do colonizador. Eu não saberia te dizer, assim, sociologicamente falando, se isso acontece no Brasil.

A confusão entre as noções de direito e mimo é compreensível dentro de tal regime discursivo, que classifica a população mundial a partir de geoidentidades (“negros", “árabes”) concebidas mediante a ideia de raça (QUIJANO, 2000; 2005). Tal enfoque culturalista, típico dos discursos modernizantes, faz parte, como visto, de diversas narrativas brasileiras sobre o Haiti ocupado pela MINUSTAH.

A noção de etapas de desenvolvimento econômico, político ou individual e a infantilização dos haitianos ou do próprio Haiti a partir de uma série de metáforas temporais e etárias é constante nas vozes dos entrevistados. A colonialidade do poder é transmitida como natural por tais vias narrativas. E a retirada ou negação de agência aos haitianos é ampla, excetuando-se os momentos em que é preciso responsabilizá-los pelos fracassos dos planos ou metas de desenvolvimento concebidos no exterior. O Haiti, neste regime discursivo, não é responsável por seu próprio futuro. ${ }^{278}$

\footnotetext{
${ }^{278}$ Tal agência externa substitui, como notado por especialistas no tema, aquela negada aos locais: "The project thus established civil-military partnerships - engaging 'ungoverned' communities, or people that could not 'properly govern' their lives, habitats and livestock - fostering their endangered livelihoods (CONSTANTINOU; OPONDO, 2016, p. 308).
} 
Autoridades do Estado brasileiro, como visto, estimularam tal discurso. Lula da Silva (2014), afirma que estamos em um "processo de devolução ao povo haitiano da responsabilidade plena por sua segurança”. ${ }^{279}$ E conclui seu pronunciamento com uma pergunta retórica e contundente: "Será que não está na hora das Nações Unidas convocarem uma nova Conferencia sobre o Haiti, para discutirmos francamente o que foi feito nesses dez anos e o que fazer daqui para frente?". O mundo deve seguir decidindo e planejando o futuro do Haiti, de acordo com esta narrativa avançada não apenas por vozes provenientes das grandes potências, mas também advindas de lugares de fala pós-coloniais, por importantes atores políticos de países como o Brasil. De fato, parece que "testemunhamos uma nova forma, pós-colonial e mais insidiosa, de governamentalização" (CONSTANTINOU; OPONDO, 2016, p. 312).

\section{Considerações finais}

Os entrevistados para a confecção deste capítulo eram perceptivelmente inteligentes, bem-formados e exitosos dentro de suas respectivas carreiras e funções. O tempo cedido para esta investigação é merecedor de nosso agradecimento. Conforme indicado por Heathershaw (2008), nenhum deles parecia ser uma pessoa cínica (salvo uma única exceção). Pelo contrário, aparentavam ser comprometidos e, sobretudo, crentes no valor de seu trabalho, encarado de fato como uma verdadeira missão por diplomatas, militares, freiras ou policiais brasileiros à serviço da MINUSTAH, ou a ela conectados, no Haiti. Fica nítido como estas vozes entendem seu papel como sinceramente benigno, altruísta e solidário, visando apenas o melhoramento do Outro, da maneira menos violenta possível. Como sintetizado pelo então chanceler Celso Amorim: "Creio que a contribuição do Brasil foi importante para que, hoje, o Haiti tenha uma perspectiva de futuro" (2006, p. 2); sempre ressaltando que "estamos ajudando ao Haiti, não a nós mesmos" (2010, p. 53). E justamente este aspecto é de grande interesse para a presente pesquisa, uma vez que remete de imediato aos alertas de Said (2003) sobre o discurso do Orientalismo como prática de poder. ${ }^{280}$ São igualmente relevantes,

\footnotetext{
${ }^{279}$ Itálico adicionado.

${ }^{280}$ Para as razões que levam Edward Said (2003) a estudar o Orientalismo como relação de poder, apoiando-se na noção foucaultiana de discurso, conferir Said (2003, p. 3-4). Para uma crítica posterior, do mesmo autor, às escolhas políticas e teóricas de Foucault, que é acusado de ignorar o “contexto imperial de suas próprias teorias”, ver Said (1994, p. 29-30; 335-336).
} 
por tal motivo, para a investigação sobre o Haitianismo brasileiro e as vozes brasileiras sobre o Haiti no contexto da MINUSTAH:

Every single empire in its official discourse has said that it is not like all the others, that its circumstances are special, that it has a mission to enlighten, civilize, bring order and democracy, and that it uses force only as a last resort. And, sadder still, there always is a chorus of willing intellectuals to say calming words about benign or altruistic empires, as if one shouldn't trust the evidence of one's eyes watching the destruction and the misery and death brought by the latest mission civilizatrice. (SAID, 2003, p. xvi - itálico no original)

Nossa análise hipercrítica, portanto, não versa sobre atitudes ou valores pessoais revelados pelas respostas às perguntas do questionário desta investigação. O foco é, antes de tudo, no regime discursivo que torna tais narrativas e posturas frente ao Haiti como possíveis, ativáveis e disponíveis para serem empregadas por quem é convidado a expressar-se sobre tal realidade. Por este motivo a identidade dos entrevistados não foi revelada, apenas indicando-se (e insistindo) sobre seus respectivos cargos funcionais de modo a salientar seu pertencimento a relevantes setores do Estado e do debate público no Brasil.

Expressões de racismo aberto foram cautelosamente evitadas pelos entrevistados, que escolhiam cuidadosamente as palavras para expor seus pensamentos, encenando assim o "gracioso e generoso gesto liberal" (VITALIS, 2000, p. 353). Entretanto, a classificação da população mundial a partir da ideia de raça, ou seja, a colonialidade de seus saberes, emerge com força à medida em que as reflexões avançam e o regime discursivo do qual fazem parte se apresenta. Algumas verdades sobre a índole dos haitianos, hábitos que causam estranheza, sua cultura diferente e até mesmo os traços que são encontráveis em comum com o Brasil e os brasileiros são reveladores desta colonialidade das narrativas que não jazem escondidas nas profundezas, mas figuram na própria superfície do discurso.

A insistência nos temas da negritude e da incapacidade dos haitianos para gerirem-se autonomamente confirmam, em conjunto, a validade desta chave-deleitura para analisar as vozes brasileiras sobre o Haiti. É deste modo que vão sendo construídas, pouco a pouco, imagens e representações diversas do Outro haitiano que, todavia, convergem para a reafirmação de ontologias de alteridade, muitas vezes elaboradas a partir de teleologias de modernização aplicáveis à objetos 
identificados por seu atraso pessoal, coletivo ou nacional em termos políticos, econômicos, intelectuais ou culturais. A razão humanitária brasileira assemelha-se, assim, à "razão colonial” e sua "taxonomia do afeto", descritas por Grovogui (2006) nos seguintes termos:

This means that colonial reason was guided by passion, and not the other way round. [Anne Laura] Stoler further argues that the rationality of the colonial state was frequently used to produce a taxonomy of affect: an emotional economy that distinguished the West (likened to an adult guardian of children - godfearing believer, civilized moralizer, or rational modernizer) in order to oppose it to the non-West, whose inhabitants are then likened to children, heathens, barbarians, irrational beings. (2006, p. 34 - itálico no original)

Ao mesmo tempo, esta colonialidade dos olhares brasileiros é mobilizada em concomitância a expressões da necessidade de exercer poder disciplinar e biopolítico sobre a população haitiana, entendida como desviante de padrões de comportamento tidos como normais. Frente à anormalidade ou anomalias haitianas - pessoais ou sociais - resta a tarefa, quiçá mesmo uma obrigação ética, de normalizá-los, à força, se preciso. E, para tanto, é suficiente seguir como referente a padronização e a escala de valores oferecida pela "nova moral internacional" e seu liberalismo interventor (VIANNA, 1947, p. 106).

Afinal, conforme assinalado, dentre outros, por Castro-Gómez (2006), Constantinou e Opondo (2016), Duffield (2007) e Heathershaw (2008), a governamentalidade presente no projeto da paz liberal expressa-se não apenas pelo exercício do poder de intervir, disciplinar e controlar uma dada população. Em outras palavras, não apenas o poder, em última instancia, sobre a morte, que os militares da força da ONU possuem no país ocupado, mediante o mandato baseado no capítulo VII de sua Carta. Mas sobretudo - e ainda mais precisamente - mediante técnicas de produção, permissão e melhoramento da vida em espaços tidos como não assegurados por si mesmos, como o Haiti. Um lugar que após a intervenção militar comandada pelo Brasil estaria hoje "mais seguro e próspero (AMORIM, 2010 , p. 53). Este seria um projeto que promove a "militarização da diplomacia e do desenvolvimento e a diplomatização das Forças Armadas" em locais considerados como "espaços desgovernados" ou com "espaços fluidamente governáveis" (CONSTANTINOU; OPONDO, 2016, p. 308), que precisam, por isto, da fusão entre defesa, desenvolvimento e diplomacia, ou "biodiplomacia": 
Whereas biopolitics has expanded its reach and deepened its governmental methods to multiple domains around the globe - not only enhancing conditions of living but also determining who is made to live and who is let to die-biodiplomacy underscores the continuous negotiation of life that accompanies this global expansion and that has brought shifts in strategies of control, discourses of legitimization and forms of co-optation and cohabitation beyond governance. (2016, p. 309)

Não somente permitir a vida, portanto, mas determinar como ela deve ser vivida, de acordo com o regime de verdade vigente no âmbito das intervenções militar-humanitárias atuais, incluindo aquelas animadas por Estados pós-coloniais, como o Brasil. A maior capacidade brasileira em desempenhar tal tarefa, ou missão, foi insistentemente afirmada por vozes in situ que destacaram alguma técnica, dom ou proximidade cultural (racial) que facilitaria o exercício do poder normalizador frente ao Outro durante operações do regime bélico-discursivo da paz liberal sob comando brasileiro, reiterando o argumento de intelectuais e especialistas favoráveis à intervenção (ABDENUR; CAL, 2017; BRAGA, 2017; CEZNE; HAMANN, 2016; CLAUHS, 2013; HISRT, 2012; KALIL; NAPOLEÃO, 2015; KAWAGUTI, 2006; MORENO et al., 2012; NASSER, 2012; SOUZA NETO, 2012; VALLER FILHO, 2007; VIANA, 2009). Um deles salienta a "exportabilidade" deste "modelo brasileiro" de pacificação Sul-Sul (KENKEL, 2011, p. 30), fruto de uma paz liberal pós-colonial. ${ }^{281}$

O intensamente propalado sucesso termina recaindo sobre o mesmo expediente argumentativo acerca das especificidades pacificadoras brasileiras, que se tornam dispositivos a serem reproduzidos para tarefas de natureza semelhante alhures. Para isto, reitera-se sempre que o Brasil é mais competente para este tipo de missão, dados seus atributos socioculturais e raciais. Tal eficiência do Brasil, no entanto, é celebrada automaticamente sem que os efeitos de poder decorrentes de tais práticas e atitudes sejam suficientemente percebidos e interrogados. ${ }^{282} \mathrm{O}$ exaustivamente mencionado sucesso das políticas brasileiras de pacificação no Haiti, fruto de hibridismos entre identidades e diferenças, baseia-se, deste modo, na

\footnotetext{
281 "A further forte of the burgeoning Brazilian model is the export of technologies and techniques used in the country's own domestic context in situations of underdevelopment and violence (...) Taken holistically, this approach represents a distinct Brazilian contribution to the development of peacebuilding paradigms" (KENKEL, 2011, p. 29-30).

${ }^{282}$ Como visto no capítulo 2, um diplomata entusiasta da intervenção no Haiti e do emergente modelo brasileiro empregado em missões da paz liberal admite, sem reservas, que "existe certo fetiche em relação às operações de paz", acrescentando que reconhecia em si mesmo a fascinação que lhe produzia esta "mística orientalista" e a "sedução salvacionista" proporcionadas pelo tema (NASSER, 2012, p. 213).
} 
ideia de que o gerenciamento de populações classificadas como negras e empobrecidas é uma tecnologia distintiva e valiosa possuída pelo Brasil, cujas raízes epistêmicas e empáticas seriam históricas e culturais, senão mesmo genéticas. Afinal, trata-se de um "povo-irmão, de raízes africanas como as nossas" (LULA DA SILVA, 2010, p. 51).

Em outras palavras - mas ainda de acordo com este mesmo discurso - o que destacaria o Brasil frente aos demais proponentes de intervenções humanitárias da paz liberal seria justamente sua eficácia em combinar, ao mesmo tempo, governamentalidade e colonialidade no exercício do poder: o biopoder do Estado brasileiro é narrado como melhor justamente por seus atributos pós-coloniais. Por tais motivos, uma genealogia do biopoder no Brasil pós-colonial deveria levar à incorporação do Haitianismo como parte desta trajetória de bem-sucedidas tecnologias de disciplinamento, dominação e normalização do Outro, ao mesmo tempo interno e externo, desenvolvidos pela modernidade/colonialidade brasileira. É a isto que se dedica o próximo capítulo da presente investigação. 


\section{CAPÍTULO 6: A MINUSTAH como Haitianismo}

Com o intuito de mapear as diferentes emergências do Haiti no discurso político brasileiro, os capítulos anteriores dedicaram sua atenção, por um lado, às instâncias de produção discursiva do Haitianismo e, por outro, aos esforços de articulação de uma narrativa em torno de um modelo brasileiro de condução das intervenções humanitárias, que teria na MINUSTAH seu exemplo principal ou mesmo fundacional. Ainda que estas duas instâncias de emergência não sejam as únicas mobilizações significativas do Haiti, trata-se de "acontecimentos discursivos" (FOUCAULT, 2016, p. 37) cujo apelo e poder são inegáveis diante da vasta difusão experimentada por ambas em diferentes espaços sociais de produção do saber, como a imprensa, academia, órgãos estatais e também os não governamentais.

É necessário, contudo, buscar analisar tais instâncias mediante uma abordagem teórico-metodológica capaz de interrogá-las criticamente de modo incisivo, a fim de contribuir com o desenvolvimento de ferramentas de enfrentamento do exercício do poder do qual participam. Uma abordagem particularmente frutífera para este intento pode ser ensaiada a partir das indicações fornecidas pelos trabalhos de Michel Foucault acerca das relações entre produção social de conhecimento e poder político.

Mesmo não sendo o único meio possível de encarar tal desafio analítico, as reflexões do filósofo francês têm o potencial de equipar os investigadores interessados em conceber o Haitianismo como discurso, uma vez que permitem interrogar os efeitos de poder ativados em sua produção. Não se trata, pois, de fazer a exegese de um autor ou de um instrumental teórico em particular, expediente muitas vezes repetido para fins diversos, mas que termina por recair no inescapável dogmatismo inerente a qualquer "method-driven social science" (WENDT, 1999, p. 40). Trata-se, isto sim, de armar-se para a batalha com os melhores meios que cada um encontra à disposição em seu tempo e lugar.

Nas páginas que se seguem, este embate será articulado em três seções. Inicialmente, será colocada em suspenso a pretensa unidade discursiva até agora sugerida sob a rubrica de 'discursos brasileiros sobre o Haiti', de modo a investigar as práticas discursivas sob análise mediante uma arqueologia do saber que revele 
as camadas daquilo que aparentam ser duas formações discursivas distintas e separadas por mais de um século. Em seguida, após delimitar tais regularidades discursivas a partir das regras de formação de seus diferentes elementos, ou níveis, será proposto dar um passo adiante, em direção a uma genealogia do Haitianismo que dê ênfase à noção de 'emergência', permitindo articular uma história deste dispositivo sem recair na "ingenuidade das cronologias" (FOUCAULT, 2016, p. 30).

Balizadas desta forma tático-metodológica, será possível avançar na proposição central desta tese acerca das relações entre o Haitianismo e as narrativas sobre a MINUSTAH, no sentido de compreender como os mecanismos de subjetivação existentes no primeiro caso são reativados pelos discursos constitutivos do segundo. Esta operação lança luz sobre um feixe de relações até então invisíveis entre as práticas discursivas estudadas e permite questionar a separação ontológica entre ambas, trazendo à tona os efeitos de poder, ao mesmo tempo biopolíticos e coloniais, acarretados pelo emprego da razão humanitária atual em operações de pacificação supostamente menos violentas do que as tradicionalmente observadas em intervenções da paz liberal.

Ao fim, serão indicadas novas modalidades de investigação a partir das trilhas abertas pela presente abordagem, enfatizando a possibilidade de pensar o Haitianismo para além das narrativas sobre o Haiti, assim como um instrumento de incisão crítica sobre práticas políticas que atravessam a dicotomia interno/externo constitutiva da teorização das Relações Internacionais e que tampouco deve ficar restrito ao âmbito da modernidade/colonialidade brasileira, já que informa, mais amplamente, todo o discurso humanitário pós-colonial.

\section{Regularidades e formações discursivas: a arqueologia do Haitianismo}

Edward Said (2003) afirmou ter encontrado nas discussões de Michel Foucault sobre a noção de discurso um instrumento útil para a abordagem do Orientalismo. A mesma utilidade parece ser encontrada, pela presente investigação, para efetuar a análise do Haitianismo. O que significa, então, tratar o Haitianismo como discurso? Em A Arqueologia do Saber (2016) há uma reflexão metodológica cujo objetivo é propor uma abordagem mais consistente; algo que conseguisse dar coerência e fornecer rigor teórico àquilo que fora produzido em trabalhos anteriores. Diante das críticas que vinha sofrendo até então, Foucault (2016) 
apresenta um esforço de teorização que encontra, dentre outras, na noção de Formação Discursiva uma ferramenta analítica com a qual consegue refinar seus métodos de investigação das relações entre saber e poder.

Para compreender a noção de Formação Discursiva é preciso colocar em suspenso as unidades geralmente apresentadas pelas ciências sociais como autoevidentes sem, no entanto, esquivar-se da busca por determinadas "regularidades discursivas", delimitáveis e finitas (FOUCAULT, 2016, p. 24). Isto implica abandonar de saída conceitos como "tradição", "influência", "desenvolvimento", “evolução", “espírito” ou "síntese” (2016, p. 25-26). Tampouco deve-se lançar mão de outras formas tradicionais de conferir unidade, expressas por noções como "a obra", "o livro" ou pelas categorias de "a ciência", "a literatura", "a política" ou "a economia" (2016, p. 27-31). Tais agrupamentos ou recortes são deveras familiares, mas carregam consigo o risco da reprodução de “continuidades irrefletidas" (2016, p. 30) às quais é preciso renunciar.

Em outras palavras, a regularidade não se dá pela aparente semelhança temática ou semântica, pela assinatura de um mesmo autor ou sequer pela categorização epistemológica em campos do saber delimitados por uma essência interna comum. No caso da presente tese, a regularidade discursiva não deveria, portanto, estar baseada no emprego de um significante ou signo linguístico em comum, como Haiti. Mais ainda, não se deve confundir o método arqueológico com uma busca por origens comuns no passado, como se isto garantisse a almejada regularidade discursiva: "não é preciso remeter o discurso à longínqua presença da origem: é preciso tratá-lo no jogo de sua instância" (2016, p. 31).

Tratar os discursos no jogo de sua instância é tarefa árdua, uma vez que implica em romper com hábitos e modalidades de agrupamento que se tornaram intuitivos. No entanto, caso bem-sucedidas, as recusas envolvidas nesta operação prometem recompensas valiosas. "Uma vez suspensas essas formas imediatas de continuidade, todo um domínio encontra-se, de fato, liberado" (2016, p. 32), diz.

Trata-se de um domínio imenso, mas que se pode definir: é constituído pelo conjunto de todos os enunciados efetivos (quer tenham sido falados ou escritos), em sua dispersão de acontecimentos e na instância própria de cada um. Antes de se ocupar, com toda certeza, de uma ciência, ou de romances, ou de discursos políticos, ou da obra um autor, ou mesmo de um livro, o material que temos a tratar, em sua neutralidade inicial, é uma população de acontecimentos no espaço do discurso em geral. 
Aparece, assim, o projeto de uma descrição dos acontecimentos discursivos como horizonte para a busca das unidades que aí se formam" (2016, p. 32-33 - itálico no original).

Desta forma, ao suspender-se aquilo que parecia conferir unidade aos discursos políticos brasileiros sobre o Haiti, abrem-se novos horizontes de investigação. À primeira vista, duas formações discursivas distintas parecem emergir, uma no século XIX, outra no século XXI. Segundo Foucault (2016, p. 47) deve-se procurar nas "regras de formação" que informam as práticas discursivas a especificidade que confere regularidade a cada uma delas, a partir da inter-relação entre quatro elementos, ou níveis, do discurso: objetos; modalidades enunciativas; conceitos; e estratégias teóricas ou escolhas temáticas.

Novamente, não se trata de meramente buscar semelhanças, "ilhas de coerência" ou uma "estrutura interna" composta por estes quatro níveis, mas, inversamente, estudar suas "formas de repartição" e descrever seus "sistemas de dispersão" (2016, p. 46). A regularidade assim concebida permite capturar "uma ordem, correlações, posições e funcionamentos, transformações” destes quatro elementos, ou níveis, de uma dada Formação, também chamada, por este motivo, de "repartição discursiva" (2016, p. 47). Estas noções evitam, segundo ele, "palavras demasiado carregadas de condições e consequências, inadequadas, aliás, para designar semelhante dispersão, tais como "ciência", ou "ideologia", ou "teoria", ou "domínio de objetividade"” (2016, p. 47).

Os capítulos anteriores forneceram um apanhado descritivo de uma população de acontecimentos discursivos, que agora podem ser relidos mediantes os sistemas de dispersão e as formas de repartição resultantes das relações entre objetos, modalidades enunciativas, conceitos e escolhas temáticas. Mesmo estando fora do escopo desta investigação a descrição exaustiva de todas as regras de formação das regularidades discursivas sob estudo, já é possível estabelecer "um conjunto de regras que são imanentes a uma prática e a definem em sua especificidade" (2016, p. 57). Esta mirada permite, ademais, dar inteligibilidade à aparente cacofonia e às contradições observadas tanto nas narrativas sobre o Haitianismo do século XIX, estudadas nos capítulos 3 e 4, quanto naquelas sobre o jeito brasileiro de comandar operações de paz, vistas no capítulo 5. 


\subsection{Formação discursiva dos saberes do Haitianismo - século XIX}

No discurso dos historiadores existe uma série de dispersões importantes entre si. Elas são ainda mais salientes se forem contrastados os usos emanados da historiografia com os enunciados encontrados nas fontes primárias do Período Regencial. Por exemplo, vê-se uma repartição entre abordagens historiográficas que entendem o Haitianismo predominantemente como medo branco, como em Azevedo (2004) e Carvalho (2014), frente àquelas que o definem, sobretudo, como inspiração negra, como em Gomes e Soares (2002) ou Mott (1988). Cumpre notar que, nestes casos, os mesmos enunciados dão origem à escolhas temáticas bastante heterogêneas, assim como à constituição de distintos objetos e sujeitos que capturaram as atenções dos referidos pesquisadores: por um lado, os dilemas envolvidos na construção do Estado e a delimitação racial da nacionalidade pelas elites imperiais; por outro, as estratégias de luta e resistência ao escravismo póscolonial brasileiro por parte de quem ousava desafiar a colonialidade e o biopoder inerentes à esta mesma construção nacional. Tamanha dispersão discursiva, contudo, pôde, por vezes, fazer usos de conceitos compartilhados - como Haitianismo - ainda que atribuindo-lhe significações opostas em suas respectivas tentativas de produção de conhecimento histórico, que transitaram, assim, entre a espacialidade restrita do território brasileiro e aquela que toma como unidade de análise o Atlântico Negro como um todo.

Também se observa deslocamentos de objetos e estratégias teóricas quando cada geração ou escola da historiografia define o conceito a partir de temas repartidos entre as supostas "repercussões" ou "influências" da Revolução Haitiana sobre a sociedade brasileira versus a apropriação doméstica, consciente e até instrumental, de motifs da política internacional por atores políticos locais. Nesta dispersão discursiva, o Haitianismo perde consistência conceitual ou coerência interna (deixando de ter uma essência ontológica estática) para servir aos propósitos investigativos díspares da História Diplomática de Mello Mourão (2009), que olha do externo para o interno, e da historiografia brasilianista de Flory (1978), que lança olhar em sentido inverso.

Ao lado destes, a repartição cresce em complexidade com as abordagens positivistas de Marquese (2006), Nishikawa (2005) e Youssef (2009) que buscam negar a própria existência do Haitianismo no Brasil imperial a partir da agenda de suavizar os piores efeitos da escravidão brasileira se comparada a outros regimes 
escravistas do Caribe. Esta postura revisionista (ou negacionista) os obriga a ignorar certas fontes e desautorizar a outros enunciados como falsos, amparando-se na controversa tese de ausência de raça (BERBEL; MARQUESE, 2007) nos debates políticos imperiais. Reativam, assim, escolhas temáticas surpreendentes que repartem o campo de investigações de forma radical, mas que seguem relacionando-se com as demais correntes historiográficas por meio de debates acirrados, por exemplo, com Ferreira e Gomes (2008).

Mais ainda, ao trabalhar com flexibilidade suficiente para abarcar tanto a temática das repercussões quanto a que evita tratar a política local como epifenômeno de um acontecimento externo, Morel $(2005,2017)$ é capaz de sugerir uma reformulação dos termos dos debates. Ele propõe não apenas um novo modo de sistematizá-los, mas também introduz novos problemas de pesquisa (temas e objetos), a partir do resgate de modalidades enunciativas simpáticas à Revolução Haitiana e elogiosas de seus líderes. São enunciados ignorados, silenciados ou que haviam passado despercebidos pela literatura especializada, mas que foram proferidos por figuras de destaque do mundo político branco brasileiro, desde a crise do regime colonial em diante.

As práticas discursivas do Haitianismo que produzem como enunciadores os próprios historiadores também conduzem a sistemas com forte dispersão espaço-temporal dos objetos pesquisados que, de outra forma, poderiam ser encarados como meros erros de análise ou simplesmente falta de rigor no trato com as fontes documentais. Ainda que erros, correções e reformulações façam parte do processo de produção de formações discursivas, as enunciações de historiadores que estendem o conceito de Haitianismo para locais onde nunca foi de fato empregado (pelo menos não acompanhadas de demonstração empírica), assim como para temporalidades anteriores à sua cunhagem (ou posteriores à sua caída em desuso) podem ser encarados como estratégicas teóricas desenvolvidas a partir do discurso que produz seus enunciadores acadêmicos mediante movimentos de deslocamento, mais ou menos conscientes. ${ }^{283}$

Assim, quando Schwarcz e Sterling (2015) ou Carvalho (2014) dão vida ao conceito nos anos politicamente cruciais de 1808 ou 1822, respectivamente, mostra-

\footnotetext{
283 Dissertando sobre as regularidades discursivas, Foucault (2016) sugere que "consideremos o conjunto dos enunciados que escolheram como 'objeto' o sujeito dos discursos (seu próprio sujeito) e que se dispuseram a desenvolvê-lo como campo de conhecimentos” (2016, p. 37).
} 
-se o poder de uma prática discursiva que somente desvelaria empiricamente seus significantes mais conhecidos (Haitianismo, haitianar, haitianada) a partir de 1831, outra data decisiva nos embates domésticos e internacionais envolvendo o Brasil. Esta presença conceitual extemporânea ajuda-os a avançar suas respectivas teses (sobre a invenção sociocultural e a unidade territorial do país) sendo, portanto, compreensível enquanto estratégia teórica. De modo análogo, ao insistirem no Haitianismo como termo que circulou pelos quatro cantos do continente, Washington Nascimento (2008) e João José Reis (2000) dispersam espacialmente o conceito mediante atos de força discursivos oriundos de citações repetidas entre fontes secundárias, sem amparo documental mais sólido. Entretanto, ao agirem de tal modo, suas enunciações ajudam a evitar narrativas excessivamente internalistas que insistissem sobre supostas particularidades brasileiras, permitindo que gerações subsequentes de investigadores cultivem suspeitas saudáveis sobre as agendas políticas que se beneficiam deste tipo de enunciados e temáticas, cujas unidades de análise são exclusivamente nacionais.

Quando se incorporam os documentos de época pesquisados nesta investigação aos debates historiográficos, os sistemas de repartição atingem um grau de enredamento ainda mais acentuado e, ao mesmo tempo, difícil de agrupar. São camadas, ou modalidades, de enunciados que apresentam, pelo menos, seis direções discursivas e que fazem da topografia discursiva do Haitianismo um terreno, no mínimo, acidentado. Se por um lado as intrigas políticas e difamações pessoais conectam-se facilmente com objetivos eleitorais e ministeriais, por outro, quando se trata da punição física sobre corpos racializados como negros, ou dos argumentos sobre uma embrionária democracia racial dentro do ordenamento jurídico imperial escravista, os deslocamentos de enunciadores, conceitos e objetos do discurso são brutais.

No primeiro caso há uma operação de subjetivação bem delineável, realizada a partir da identificação do "Haitiano" com os adversários de turno tanto de Liberais Exaltados, Liberais Moderados ou Restauradores, o que trazia seus enunciadores para posições de subjetividade definidas como patrióticas, uma vez que a pecha de Haitianismo, neste caso, era usada para definir potenciais traidores da jovem nação. Por anos seguidos, importantes vozes políticas mobilizaram um conjunto delimitado de conceitos envolvendo o Haiti (Haitiano, Haitianar, Haitianada, Haitianismo) para marcar suas posições dentro de um espectro político 
trifásico, mediante estratégias de deslocamento temático impressas, por exemplo, nas páginas da Nova Luz Brasileira, Aurora Fluminense e Pão d'Assúcar, respectivamente. A cada personagem-objeto da acusação de "malvado Haitiano" produzia-se, por oposição, um novo modelo de sujeito, o "brasileiro de bem".

Repartição ainda mais acentuada se dá na relação entre os enunciados cujas escolhas temáticas estão voltadas para o debate racial propriamente dito, dispersas entre enunciados de violência abismal versus benevolência racialmente concedida. As "1.200 vergalhadas por [ser] haitiano" denunciadas pelo Bacorinho, junto com os 800 açoites sumários pela acusação de "refinado haitiano", são exemplos raros de enunciações cujo lugar-de-fala apresenta uma voz autenticamente subalterna representando a si mesma. Tal subjetivação própria das vítimas de violência também se ampara em conceitos derivados do Haitianismo para tratar, por sua vez, como objetos do discurso aqueles que eram seus algozes, no caso quase todas as facções do mundo político branco da época, "Exaltados, Republicanos, restauradores, Andradistas e Chimangos", invertendo a relação sujeito-objeto hegemônica. Mantendo a escolha temática, mas recuperando os papéis de sujeito e objeto mais frequentes, O Jururuba dos Farroupilhas denuncia que "houve preto que levou mais de mil açoites pela presunção d'Haitianismo" em outra ocasião, só que mediante um enunciado que desloca o conceito de modo a produzir uma subjetivação destinada a mostrar um lugar-de-fala privilegiado, branco, porém compadecido e moralmente indignado ante o sofrimento do Outro, "preto" e "escravo", devido à injustiça do caso (sem, contudo, questionar o regime escravista em si, ao menos não de forma direta).

Por outro lado, a formação discursiva do Haitianismo valeu-se frequentemente de enunciados pautados pela negação ou relativização desta mesma violência e discriminação raciais. Os esforços de Evaristo da Veiga para restringir o Haitianismo à uma chave política desracializada são ilustrativos dos deslocamentos aos quais o conceito foi submetido e, também, dos enunciados e objetos heterogêneos que tal discurso produziu. A equação "não se deve confundir = haitiano com homem de cor = haitianismo", que abre e fecha o artigo do Aurora Fluminense, apresenta na forma de variáveis semi-matemáticas as repartições e dispersões que este enunciador podia fazer a partir de seu "lugar institucional" de proprietário de tipografia e jornal, seu "status" de "personagem" como jornalista e deputado proeminente e, finalmente, sua "posição de sujeito" que "questiona", 
“observa", "anota" e é capaz de propor uma "organização do campo perceptivo totalmente diferente" (FOUCAULT, 2016, p. 61-63).

É assim que sua intervenção opera tanto o embranquecimento dos "homens de cor" ("tão interessados como nossos Cidadãos em que as ideias do feroz haitianismo não triunfem") simultaneamente ao movimento de enegrecer a "dois brancos, escritores bem conhecidos pela exageração de suas doutrinas”, sobre os quais "recaem justificáveis suspeitas de que trabalham em favor do haitianismo". A política de subjetivação do texto de Veiga, a partir do ambivalente conceito de Haitianismo, fica patente pela produção discursiva de um Outro dócil e domesticado, cujos interesses seriam os mesmos da classe proprietária branca, já que "dos homens de cor livres, muitos tem escravos". Transformando a exceção em regra e ignorando que no Haiti tais relações de propriedade escravocrata entre não brancos também eram possíveis (em escala bem mais ampla do que no Brasil, aliás), ele difunde enunciados que produzem sujeitos objetificados, que não falam por si mesmos, sob a alegação de que "os pardos (...) não tem no Brasil as queixas que exasperaram os homens de cor em S. Domingos". Logo, o Haitianismo, não seria um fenômeno racial, mas fruto de doutrinas políticas radicais sem qualquer relação com "as castas a que a escravatura pertence". Tal pertencimento passa, todavia, batido, excluindo maiores indagações. (Se a escravidão era desracializada, por que não havia um escravizado branco sequer?)

Seu grande adversário político, o Pão D’Assúcar, repartia este expediente discursivo mediante o traço de fronteiras políticas que produziam novos deslocamentos dos objetos do Haitianismo, reformulando a política de subjetivação do Aurora Fluminense. É desta forma que se insurge contra os Liberais que apresentariam postura antilusitana: "São haitianos esses que odeiam os Portugueses". Não se trata de simples xenofobia, pois também “[s]ão haitianos esses que toleram os insultos e ameaças dos Ingleses e Franceses que açoitam Brasileiros", e mais, que "preferem homens de outras nações (...) e chegam a ponto de mandar vir de seus países a própria comida já cozida e a roupa lavada que vestem!”. O insulto a sujeitos produzidos discursivamente mediante sua subserviência internacional também é racial, senão seria suficiente chamar os adversários de antipatrióticos (como o faz ao dizer que promovem a "discórdia em vez de patriotismo"). 
No entanto, ainda que se dirija à facções do mundo político branco, é mediante o conceito de Haitianismo que são desqualificados, literalmente denegrindo-os: "São haitianos somente os que promovem a divisão do Brasil". Por caminhos distintos, reativa-se aquela subjetivação que produzira o "haitianismo inglês" do jornalismo Liberal Exaltado da Nova Luz Brasileira. Todos, ao fim, embranquecem a possíveis aliados, enquanto escurecem a adversários e inimigos. A divisão amigo/inimigo que Carl Schmitt (2007, p. 26) identifica como distintiva do momento político per se deve possuir cores, ou raças, no mundo pós-colonial, mesmo quando a discussão é travada apenas entre homens brancos. O Outro precisa ser racializado, até quando tenta-se fazer o contrário. ${ }^{284}$

\subsection{Formação discursiva do modelo brasileiro de paz}

Por sua vez, as práticas discursivas observadas nos discursos brasileiros no âmbito da MINUSTAH apresentam um feixe de relações entre objetos, modalidades enunciativas, conceitos e escolhas temáticas ou estratégias teóricas que produzem uma população de acontecimentos discursivos cuja regularidade também pode ser vista em termos de um sistema de dispersão ou repartição entre tais elementos. O capítulo 5 já os apresentou em função de três modalidades enunciativas, agrupadas sob os tropos da ordem/caos, ontologias da diferença e teleologias modernizantes que infantilizam o Outro. É possível, no entanto, identificar outras repartições, deslocamentos, re-elaborações, negações e questionamentos que concorrem para a produção de uma formação discursiva capaz de ativar subjetivações duradouras. A principal delas versa sobre um jeito próprio dos brasileiros pacificarem o Outro.

Em paralelo aos enunciados de caos que clamam pela imposição da ordem, observou-se uma formidável oscilação entre o modo de caracterizar os objetos da pacificação: ora o Haitiano é descrito como violento, que ataca os comboios da ONU ou mesmo o selvagem que pratica linchamentos contra seus compatriotas; ora é amigável e simpático, especialmente no trato com brasileiros. Conceitos como guerra civil são a cada entrevista revisitados e re-elaborados, geralmente em busca de uma estratégia teórica ou temática que justificasse uma intervenção militar

\footnotetext{
${ }^{284}$ Interessante notar que Schmitt (2007) já caracteriza o inimigo político como o Outro, antes desta prática tornar-se comum na teoria social contemporânea, em especial nos estudos pós-coloniais. "But he is, nevertheless, the other, the stranger; and it is sufficient for his nature that he is, in a specially intense way, existentially something different and alien, so that in the extreme case conflicts with him are possible" (2007, p. 27).
} 
admitida como sui generis diante da impossibilidade de enquadrar os conflitos políticos e sociais haitianos no arcabouço conceitual típico da paz liberal até então.

Nesses movimentos, faz-se um esforço para ocultar tanto a existência de uma vida política local madura e complexa, quanto a relação de determinadas forças sociais haitianas com atores externos que promoveram (e financiaram) a MINUSTAH por 13 anos seguidos. O "povo" haitiano é narrado como objeto da intervenção, mas o partido Fanmi Lavalas e o ex-presidente Aristide são sintomaticamente excluídos dos enunciados enquanto alvos políticos diretos dos interventores. Indicativo do "by-pass" dos sujeitos políticos locais, alertado por Sabaratnam (2013), toda oposição, manifestações, armadas ou pacíficas, contra a MINUSTAH são creditadas à ação de "gangues", "traficantes" ou "criminosos", dentre outros conceitos destinados a produzir sujeitos caracterizados como apolíticos. São os "locais", possuidores de "tradições", "índole” ou "cultura" (e que a abordagem da Paz Híbrida contrapõe aos "internacionais", "ocidentais", "liberais", "racionais" ou "modernos").

Repartições e dispersões também emanam de enunciados marcados por incansáveis jogos de identidade e diferença, ajustados aos interesses específicos de cada entrevistado. Muitos chegam a se confundir ao responderem sobre semelhanças quando a pergunta era sobre as diferenças entre brasileiros e haitianos (ou inversamente, apresentando percepções acerca das diferenças quando a pergunta era exclusivamente sobre semelhanças). Tais enunciados entrecruzados formam objetos maleáveis que, no entanto, convergem para a produção de dois tipos de sujeitos bem distintos: um que controla e protege; outro que "ainda não sabe andar com as próprias pernas", conforme insistentemente advertido pelo policial brasileiro da MINUSTAH.

As enunciações neste sentido se dão mediante o emprego de conceitos diversos, mas as posições de sujeito que sobressaem são inegavelmente repetitivas das "taxonomias do afeto" descritas por Grovogui (2006). Os haitianos seriam juvenis, suas instituições ainda estariam engatinhando, seu pertencimento à modernidade e à civilização ocidental é questionável, sua capacidade de autogoverno amplamente desacreditada e suas dificuldades exclusivamente atribuídas a fatores endógenos, sem conexão com o histórico colonial e de intervenções de grandes potências no país: "são confusões deles aí", como sintetizado pelo subcomandante do Batalhão Brasileiro. Por sua parte, os brasileiros 
são sempre contrapostos a estes haitianos atrasados e infantis. O Brasil tem credibilidade na ONU, seus militares e diplomatas são respeitados por europeus e norte-americanos, possui uma economia industrial desenvolvida, já "saiu da massa" dos países do Terceiro Mundo e galgou uma "posição intermediária" no cenário internacional. Um verdadeiro “anti-Haiti”, como percebido por Schwarcz e Sterling (2015) em seu comentário sobre o Haitianismo.

Esta hierarquia entre os sujeitos produzidos neste discurso - ou melhor, entre um sujeito brasileiro e um objeto haitiano - criam as condições para um exercício do poder que é narrado como normativamente superior e pragmaticamente mais eficaz do que aquele exercido diretamente pelas grandes potências ocidentais. Devido à formação multiétnica do povo brasileiro, sua miscigenação de raças, seu passado colonial, ao fato de estar acostumado a encarar situações de pobreza e segregação racial domesticamente, enfim, por causa de alguma característica distintiva do ethos da "gente brasílica" (CLAUHS, 2013, p. 108) o brasileiro é discursivamente construído como um sujeito benevolente, cordial, uma espécie de pai piedoso, que exerce sua autoridade sem autoritarismo, sempre com o mínimo de violência possível e sem outro intuito que não a vontade sincera de ser solidário até quando pratica ingerência armada sobre Outros.

São seres dotados, genética ou socialmente, de um hibridismo que os permite agir sem o mesmo racismo de franceses ou norte-americanos em suas respectivas ocupações militares do Haiti, mesmo que os enunciados, objetos, conceitos e escolhas temáticas das vozes brasileiras racializem a diferença a todo momento, a fim de assegurar para si certo espaço de conforto civilizacional (PERSAUD, 2002). Afinal, "ninguém quer morar perto de uma favela", como bem sintetiza o policial brasileiro à serviço da MINUSTAH.

Assim, o que uma mirada para a arqueologia destas formações discursivas mostra é uma série de regras de formação de objetos, modalidades enunciativas, conceitos e estratégicas teóricas que, mediante múltiplas relações de descontinuidade, vão produzindo regimes de verdade cujo poder é atestado pela rápida difusão experimentada tanto pelas práticas discursivas do Haitianismo, no século XIX, quanto pelas que giram em torno da militarização humanitária póscolonial, no século XXI. Ao suspender-se a pretensa unidade oferecida pelo manto do 'Haiti no discurso político brasileiro' foi-se capaz de perceber uma população 
de acontecimentos discursivos cujas regularidades se produzem pelos sistemas de dispersão, ou repartição, entre estes quatro níveis, ou elementos, do discurso.

Observou-se, a princípio, duas formações discursivas singulares. Entretanto, uma análise mais detida sobre as regras de formação de cada uma também revelou que, não obstante o abandono da unidade temática anterior, é possível identificar certa regularidade na maneira em que as próprias práticas discursivas constroem seus respectivos regimes de verdade. A rigor, não se trata simplesmente de vozes brasileiras sobre o Haiti, mas de modos de desenvolver tecnologias e sistematizar conhecimentos sobre como controlar e gerir um Outro caracterizado como um objeto populacional racializado, a fim de obter sucesso nos intentos de construção de Estados pós-coloniais.

Em outras palavras, ao entender-se "o próprio discurso enquanto prática" (FOUCAULT, 2016, p. 56) foi possível realizar uma arqueologia daquilo que foi apresentado como - tomando de empréstimo um jargão empresarial utilizado pela MINUSTAH - um conjunto de boas práticas tanto de soberania como de governamentalidade. Nestes movimentos, emerge um sujeito político brasileiro especialmente capacitado para tal desafio: firme, porém humanizado, que consegue sucesso via uma escravidão duradoura, porém menos racializada e mais doce que as demais; ou longas intervenções militares, ainda que menos violentas e supostamente menos racistas que a maioria das outras na paz liberal.

A problemática do Haitianismo e a do humanitarismo militarizado pós-colonial não precisam, portanto, serem mantidas isoladas uma da outra. Pelo contrário, mesmo que haja diferenças óbvias nos elementos do discurso de cada, também é certo que existem jogos de relações que podem ser feitos com certa liberdade.

Relações entre os enunciados (mesmo que escapem à consciência do autor; mesmo que se trate de enunciados que não têm o mesmo autor; mesmo que os autores não se conheçam); relações entre grupos de enunciados assim estabelecidos (mesmo que esses grupos não remetam aos mesmos domínios nem à domínios vizinhos; mesmo que não tenham o mesmo nível formal; mesmo que não constituam o lugar de trocas que podem ser determinadas); relações entre enunciados ou grupos de enunciados e acontecimentos de uma ordem inteiramente diferente (técnica, econômica, social, política). Fazer aparecer, em sua pureza, o espaço em que se desenvolvem os acontecimentos discursivos não é tentar restabelecê-lo em um isolamento que nada poderia superar; não é fechá-lo em si mesmo; é tornar-se livre para descrever, nele e fora dele, jogos de relações. (FOUCAULT, 2016, p. 35) 
Assim, em se tratando de práticas relacionáveis, ainda que mediante regras de formação próprias, continua fazendo sentido tratá-las como formações discursivas realmente tão distintas? Mais ainda, se os efeitos de poder destas práticas, i. e., a produção de um sujeito Brasileiro benévolo e o controle do Outro racializado por um Estado pós-colonial, são aparentemente os mesmos, por que não dar um passo adiante no sentido de entendê-las como constitutivas de uma mesma formação discursiva? A próxima seção faz justamente isso, ao transitar da arqueologia para a genealogia do Haitianismo, ainda na companhia das reflexões teóricas de Michel Foucault.

\section{Emergência e descontinuidade: rumo à genealogia do Haitianismo}

Transitar da arqueologia para a genealogia do Haitianismo não significa trocar de método ou introduzir um novo arcabouço teórico. Trata-se, isto sim, de fazer da análise de discursos efetuada previamente um instrumento de luta contra os mecanismos e dispositivos pelos quais o poder é exercido. ${ }^{285}$ Desta forma, ao propor que as narrativas sobre o Haitianismo oitocentista junto àquelas sobre um modelo pós-colonial de intervenção desenvolvido pelo Brasil com sua ocupação militar do Haiti formem parte de uma mesma formação discursiva, o passo que está sendo dado não é no sentido de seguir analisando a discursividade local de cada uma destas irrupções, mas de enfrentar os efeitos de poder inerentes à constituição de um regime de verdade que se estabeleceu sobre o suposto sucesso do Brasil na MINUSTAH. Afinal, "o saber não é feito para compreender, ele é feito para cortar" (FOUCAULT, 1979, p. 28).

É justamente para cortar ao máximo este regime de verdade oficialmente cunhado por burocratas governamentais e repetido ad nauseam por acadêmicos de Relações Internacionais, jornalistas e funcionários de ONGs que se torna necessário empregar uma tática de combate adequada.

\footnotetext{
285 Para uma diferenciação entre as noções de mecanismo e dispositivo, que é mais amplo e engloba a primeira, ver a discussão pormenorizada de Giorgio Agamben (2005) sobre a terminologia de Foucault. Ele os diferencia assim: "Os dispositivos são precisamente o que na estratégia foucaultiana ocupa o lugar dos Universais [para Hegel]: não simplesmente esta ou aquela medida de segurança, esta ou aquela tecnologia do poder, e nem mesmo uma maioria obtida por abstração; de preferência, como dizia na entrevista de 1977 [Dits e ecrits], 'a rede' (le reseau) que se estabelece entre estes elementos (...) uma série de práticas e de mecanismos (ao mesmo tempo linguísticos e não linguísticos, jurídicos, técnicos e militares) com o objetivo de fazer frente a uma urgência e obter um efeito (2005, p. 11).
} 
Enquanto a arqueologia é o método próprio à análise da discursividade local, a genealogia é a tática que, a partir da discursividade local assim descrita, ativa os saberes libertos da sujeição que emergem desta discursividade. (FOUCAULT, 1979 , p. 172 - negrito adicionado)

Assim, evita-se o risco de ser simplesmente mais um brasileiro falando sobre o Haiti. Ou pior, tentando dar voz aos haitianos para que expressem uma contraverdade sobre a ocupação militar de seu país. Ambas as tarefas já foram feitas, desde o início da intervenção, não faltando exemplos de tentativas neste sentido. ${ }^{286}$ Porém, o impacto destas iniciativas foi limitado: tanto as votações do Senado haitiano que exigiam a saída das tropas, quanto as tentativas de dar voz à resistência haitiana foram subsumidas pelo discurso oficial, dada a brutal assimetria de forças, meios de difusão e também aos problemas inerentes em colocar-se na posição de dar voz ou falar pelo Outro subalternizado (Spivak, 1988). A participação de diversos governos latino-americanos identificados com forças de esquerda em seus países também tornou mais difícil a organização de um grande movimento continental de rechaço à esta operação de latino-americanizar o Haiti, conforme expresso pelo ex-chanceler e Ministro da Defesa brasileiro Celso Amorim (2006). Em que pese suas possíveis boas intenções, não lhe ocorreu, no entanto, que a MINUSTAH pode ter agido, uma vez mais, para evitar exatamente o processo inverso: o de haitianizar a América Latina.

Em Nietzsche, a Genealogia e a História, Foucault (1979) oferece sugestões sobre como pensar relações de poder no tempo sem recair naquilo que chama provocativamente de "história dos historiadores" (1979, p. 26). Seria inadequado, pois, tentar sugerir uma história de contínua e ininterrupta relação de alteridade entre Brasil e Haiti na qual o primeiro fosse o grande protagonista da dominação ou portador de uma obsessão paranoica com o segundo, que atravessasse séculos, desde suas respectivas independências, sem modificar-se.

A genealogia não pretende recuar no tempo para restabelecer uma grande continuidade para além da dispersão do esquecimento; sua tarefa não é a de mostrar que o passado ainda está lá, bem vivo no presente, animando-o ainda em segredo, depois de ter imposto a todos os obstáculos do percurso uma forma delineada desde

\footnotetext{
286 Ainda em 2005, uma Missão Internacional de Investigação e Solidariedade com o Haiti foi realizada por organizações da sociedade civil latino-americana e caribenha com o intuito de colher registros e apresentar denúncias quanto às violações de direitos humanos ocorridas já no primeiro ano de atuação da MINUSTAH. O relatório final, intitulado Haiti: Soberania e Dignidade (2007), é um dos muitos documentos produzidos pelas várias campanhas de retirada das tropas que buscaram fazer um contraponto aos discursos oficiais durante todos os anos de duração da intervenção, como visto no capítulo 2 .
} 
o início. Nada que se assemelhe à evolução de uma espécie, ao destino de um povo (1979, p. 21).

Com efeito, seria por demais simplório tentar fazer crer que tudo não passa de um eterno embate trans-histórico entre um modelo revolucionário haitiano e seu contraparte conservador brasileiro, como se tais entes, ou sujeitos do discurso, tivessem uma estabilidade ontológica definida por alguma essência interna de cada um. Isto posto, tais inadequações não significam que seja impossível traçar uma genealogia destas relações de poder que emergem com as práticas discursivas aqui estudadas. "Trata-se de fazer da história uma contramemória e de desdobrar consequentemente toda uma outra forma do tempo" (1979, p. 33).

Esta contramemória começa justamente por relembrar da existência do Haitianismo como acontecimento discursivo de peso na História do Brasil. Um dado que pareceria óbvio para iniciar qualquer estudo sobre a MINUSTAH, mas que nenhum dos entrevistados sabia exatamente o que era, assim como quase nenhum dos artigos ou reportagens simpáticos à pacificação exitosa do Haiti teve a coragem de mencionar. Fazê-lo agora é uma forma de promover a "insurreição dos saberes subjugados" que Foucault (2006, p. 21) definia como objetivo tático da genealogia. Portanto, a simples recuperação da existência - e, mais ainda, o estudo sistemático - do Haitianismo podem colocar em xeque aquilo que é vendido como a novidade distintiva brasileira nas operações de paz.

Reemergir não significa o desenrolar de uma continuidade imutável ou mesmo uma repetição idêntica às manifestações anteriores. A noção de emergência de um acontecimento discursivo permite abordar justamente esta irrupção de práticas singulares, mas que podem ser reativadas sob formas novas, dentro de formações discursivas com "escalas cronológicas bastante vastas" (FOUCAULT, 2016, p. 37). ${ }^{287}$ Por exemplo, o tom fraterno e condescendente de Evaristo da Veiga

\footnotetext{
287 Ele diz: "Na verdade, a supressão sistemática das unidades inteiramente aceitas permite, inicialmente, restituir ao enunciado sua singularidade de acontecimento e mostrar que a descontinuidade não é somente um desses grandes acidentes que produzem uma falha na geologia da história, mas já no simples fato do enunciado; faz-se, assim, com que ele surja em sua irrupção histórica; o que se tenta observar é essa incisão que ele constitui, essa irredutível - e muito frequentemente minúscula - emergência (...) Trata-se de um acontecimento estranho, por certo: inicialmente porque está ligado, de um lado, a um gesto de escrita ou à articulação de uma palavra, mas, por outro lado, abre para si mesmo uma existência remanescente no campo de uma memória, ou na materialidade dos manuscritos, dos livros e de qualquer forma de registro; em seguida, porque é único como todo acontecimento, mas está aberto à repetição, à transformação, à reativação; finalmente por que está ligado não apenas a situações que o provocam, e a consequências por ele ocasionadas, mas, ao mesmo tempo, e segundo uma modalidade inteiramente diferente, a enunciados que o precedem e o seguem (FOUCAULT, 2016, p. 34-35 - negrito adicionado).
} 
com os "homens de cor" ordeiros e pacíficos, junto ao olhar piedoso do Jurujuba dos Farroupilhas contra os castigos físicos a negros escravizados pelo mero rumor de Haitianismo transmitem, em seu tempo e lugar, uma afetividade inter-racial (certamente vertical, hierárquica) que remete, ou melhor, é reativada pelas declarações de afeto aos haitianos feitas pelos militares, policiais e diplomatas brasileiros durante a intervenção da MINUSTAH. Tais manifestações sentimentais positivas são intercaladas, em cada uma das instâncias de irrupção, por lacunas ou mesmo negações desta afetividade romântica, quando os mesmos enunciadores procuram salvaguardar-se contra a violência ou esperteza do Outro, também encarados como uma ameaça que deve provocar medo e cautela em quem interage com eles. Este retorno, portanto, também acontece com os sentimentos negativos presentes no discurso daquilo que agora pode-se começar a chamar de uma genealogia do Haitianismo.

\footnotetext{
Daí, para a genealogia, um indispensável demorar-se: marcar a singularidade dos acontecimentos, longe de toda finalidade monótona; espreitá-los lá onde menos se os esperava e naquilo que é tido como não possuindo história - os sentimentos, o amor, a consciência, os instintos; aprender seu retorno não para traçar a curva lenta de uma evolução, mas para reencontrar as diferentes cenas onde eles desempenharam papéis distintos; e até para definir o ponto de sua lacuna, o momento em que eles não aconteceram. (FOUCAULT, 1979, p. 15)
}

Estas diferentes cenas formam, contudo, o mesmo drama, sob a ótica da genealogia. "Em certo sentido, a peça representada nesse teatro sem lugar é sempre a mesma: é a aquela que repetem indefinidamente os dominadores e os dominados" (1979, p. 24). Assim, observa-se a emergência de acontecimentos discursivos que se inter-relacionam mediante as práticas e efeitos de poder comungados pelas narrativas haitianistas de ontem com a razão humanitária haitianista atual. Um deles diz respeito à noção de modelo: no século XIX, queria-se evitar a transposição de um "modelo haitiano" (MOREL, 2017, p. 25-26) para o Brasil escravista; no século XXI, por sua vez, fala-se muito na "exportabilidade do modelo brasileiro" de pacificação para locais como o Haiti (KENKEL, 2011, p. 28-30).

Fundamentalmente, ambas as emergências são repletas de colonialidade e biopoder, como visto ao longo desta tese. Um exercício do poder cujo alvo é o Outro racializado. É salutar que ambas também se apresentem como duas originalidades brasileiras: o país que desenvolveu um modelo próprio de pacificação do Haiti é o único espaço político que produzira um inovador léxico 
envolvendo esta mesma ilha caribenha. Desta maneira, tais irrupções recorrem a um local identificado por sua desordem e negritude (SCARAMAL, 2006) como um objeto de alteridade frente ao qual afirma-se a existência de um sujeito brasileiro, ordeiro e não tão negro assim, ainda que o suficiente para entender e gerir o contato necessário com o Outro. Mas branco o suficiente para ditar-lhe ordens a partir de uma posição de autoridade e superioridade civilizacional.

Mais que isso, em ambas as irrupções, há narrativas que se pretendem amistosas aos subalternos, mas que revelam esta mirada hierárquica: no século XIX os Liberais Exaltados do Nova Luz Brasileira e Jurujuba dos Farroupilhas pediam "reformas a bem dos pretos" e defendiam os que eram castigados por suspeita de Haitianismo, mas ao mesmo tempo afirmavam que eram estúpidos, analfabetos e ignorantes. No século XXI, o vice-cônsul do Brasil no Haiti e o policial entrevistado na MINUSTAH colocam em dúvida a presença do Haiti na civilização ocidental, sua bagagem intelectual, a própria inteligência e maturidade dos haitianos, como visto no capítulo anterior, mesmo que afirmam seu afeto por eles a todo instante.

Outra reativação importante é a relevância dos rumores sobre revoltas populares de populações negras em ambas as emergências discursivas do Haitianismo. O poder dos boatos em provocar reações de medo na população branca e mobilização de tropas foi marcante nas duas irrupções estudadas aqui. Como visto no capítulo 3, "[n]o século XIX, quando os periódicos ainda eram poucos, mas as fofocas, muitas, o Haiti frequentou as manchetes e as boticas", dizem Schwarcz e Sterling (2015), acrescentando que "como não haviam notícias objetivas, sobrava o temor" (2015, p. 228). Em linha similar, Malaguti Batista (2014) e Morel (2017) enfatizaram o poder dos rumores sobre Haitianismo em produzir resultados políticos e militares. E como visto no capítulo 4, os boatos eram o suficiente para levar ao açoite, prisão e morte de negros acusados de Haitianismo, além de colocar os regimentos militares da Corte em prontidão. Também no âmbito da MINUSTAH, esta prática se repetia. Como informa um oficial de inteligência brasileiro que atuou no Estado Maior da missão logo em seu início, houve repetidas situações que chamam a atenção pelas similaridades com a primeira irrupção de Haitianismo:

O resultado direto é que a missão ficava extremamente vulnerável a rumores e agendas externas. Por inúmeras vezes, a Força Militar foi empregada diante de informes sobre situações iminentes que, invariavelmente, não ocorriam. Contudo, 
sem ter como confirmar a veracidade, não havia outra solução que não o emprego da tropa. Tal situação, principalmente durante os momentos de maior tensão, causou elevado desgaste à tropa. (BRAGA, 2017, p. 40)

Há também inversões importantes nos enunciados que compõem a genealogia do Haitianismo, pois "[a]s diferentes emergências que se podem demarcar não são figuras sucessivas de uma mesma significação; são efeitos de substituição, reposição e deslocamento, conquistas disfarçadas, inversões sistemáticas" (FOUCAULT, 1979, p. 26). Antes queria-se ser diferente do Haiti, ou seja, evitar a qualquer modo uma repetição da Revolução Haitiana em terras brasileiras. Havia uma busca constante por convencer que o regime escravista no Brasil era mais suave do que nas Antilhas. Hoje, inversamente, insiste-se na semelhança, sobretudo racial ("irmandade africana"), entre as duas nações, como se houvesse, no discurso, uma vontade de ser parecido com o Haiti. Embora tanto as enunciações de identidade como de diferença sejam amplamente questionáveis, pela forma como são construídas e apresentadas, seus efeitos de poder atendem a uma lógica similar. Especialmente no sentido da subjetivação do $E u$ brasileiro, dotado de uma capacidade controladora não violenta, mesmo ao afirmar sua força.

As inversões prosseguem: se antes o Haitianismo servia para estrangeirizar a diferença, tratando como externo, ou importado, a um perigo que era interno e autóctone - fruto de seu próprio sistema escravista - agora ele busca nacionalizar a esta mesma diferença, sugerindo que o Outro encontrado no exterior seria, na verdade, irmão ou quase-idêntico ao Outro doméstico. A missão é, portanto, domesticá-los, expulsá-los; ou, se preciso, exterminá-los. Em todo caso, há uma reativação importante também no que se refere aos infindáveis jogos de linguagem entre interno e externo nas duas ocasiões estudadas, em linha com os alertas de Walker (2013) sobre a política de poder do Estado soberano moderno.

Tanto repetições quanto inversões fazem parte, assim, deste delineamento da genealogia do Haitianismo. É relevante notar que em termos de efeitos de poder, a instância máxima alcançada por estes jogos discursivos é a produção, reprodução ou fortalecimento de Estados pós-coloniais. Seja o Brasil pós-independência e pósabdicação na década de 1830; seja o Haiti atual, que precisaria ser refundado ou ter um novo começo, segundo as palavras de Bush (2004) $)^{288}$ ou Amorim (2006). No

\footnotetext{
${ }^{288}$ As declarações do então presidente Bush estão em reportagem de Polgreen \& Weiner (2004).
} 
primeiro caso, operava principalmente a lógica hobbesiana da soberania. ${ }^{289}$ No segundo, predominaria a razão governamental em face da suposta incapacidade haitiana de firmar seu próprio contrato social autonomamente. ${ }^{290}$ Ademais, a intervenção humanitária sobre o Haiti ao mesmo tempo promove e demonstra a força do Estado pós-colonial brasileiro para além de suas fronteiras, dando mostras do grau de fortalecimento estatal obtido, verdadeiro sucesso que ora projeta-se para fora: nas palavras do subcomandante do BRABAT, vistas no capítulo anterior, a MINUSTAH significaria, sobretudo, "projeção de poder" do Brasil. O general Vieira Neto (2017) não apenas concorda, mas ratifica que:

O engajamento do Brasil neste tipo de ajuda internacional pode continuar a ocorrer, sem prejuízo das capacidades deixadas em território nacional. Esse julgamento merece consideração além do que venha a ser apresentado como dificuldades momentâneas, de forma que a decisão possa ser adotada pelo Brasil em correspondência com o que se espera a seu respeito, em âmbito interno e externo, como um Estado forte, estável, absolutamente soberano e sintonizado com as causas mais relevantes elencadas pela comunidade internacional. (2017, p. 23 - negrito adicionado)

Por isto, não surpreende que se perceba um aguçado ufanismo informando a ambas irrupções estudadas nesta genealogia do Haitianismo, já que a celebração do Estado brasileiro é fonte e efeito destas práticas discursivas. Seus enunciadores ocupam posições de sujeito razoavelmente comuns, conformados pelos lugares-defala institucionais da burocracia estatal, da imprensa e do bacharelato. Contudo, se a existência de discursos ufanistas não surpreende na atmosfera nativista do imediato pós-abdicação do monarca face a Revolução de 7 de abril de 1831; ou que tampouco seja surpreendente que vozes da caserna e da diplomacia professem um nacionalismo axiomático, não deixa de causar estranheza a naturalidade com que acadêmicos (os bacharéis de hoje) de Relações Internacionais, inclusive os que afirmam teorizar criticamente, reforcem o mesmo regime de verdade patriótico que marca indelevelmente a história do Haitianismo. Cortada pela genealogia, esta

\footnotetext{
${ }^{289}$ Ver a respeito a discussão de Ilmar Rohloff de Mattos (2005) sobre a identificação da noção de Império do Brasil com Nação Brasileira e a importância de uma cabeça que dirigisse este novo corpo político soberano em construção na primeira metade do século XIX. Evaristo da Veiga é citado como um dos principais arquitetos e artífices deste processo, marcado tanto por heranças coloniais como por inovações. Para Hobbes (2012, p. 15-16), "a soberania é uma alma artificial” do "corpo político".

${ }^{290}$ Ver, a respeito, o volume editado por Larner e Walter (2004), sobre Governamentalidade Global.
} 
historicidade nacionalista é impugnada junto com o sujeito nacional assim produzido.

\begin{abstract}
A história, genealogicamente dirigida, não tem por fim reencontrar as raízes de nossa identidade, mas ao contrário, se obstinar em dissipá-la; ela não pretende demarcar o território único de onde nós viemos, essa primeira pátria à qual os metafísicos prometem que nós retornaremos; ela pretende fazer aparecer todas as descontinuidades que nos atravessam. (FOUCAULT, 1979, p. 35)
\end{abstract}

Para dissipar esta identidade, sempre reafirmada pelas irrupções de Haitianismo, é preciso duvidar das narrativas sobre as origens e formações de um povo, deste sujeito soberano que é base, aliás, para toda forma de nacionalismo do tipo estudado na presente pesquisa. Assim sendo, quando Foucault (1979, p. 32) afirma que o europeu "não tem identidade" porque "ele ignora as raças que se misturaram nele", seu objetivo é nítido: busca retalhar o senso de pureza racial de seus conterrâneos. No caso do Brasil, onde o mito de fundação das raízes de nossa identidade não é o da pureza, mas o da miscigenação racial tripartite, a tarefa passa a ser justamente interrogar e enfrentar os efeitos de poder deste discurso sobre o hibridismo racial do brasileiro. Expediente que foi ativado com intensidade nos debates sobre Haitianismo, tanto nos jornais como no parlamento imperial brasileiro:

\begin{abstract}
A palavra - haitiano ou haitianismo - significa uma ordem de coisas que existe, ou existia em um país que nunca teve nem tem relação com o que se passou em nosso país. As colônias portuguesas e as colônias espanholas, principalmente as primeiras foram sempre regidas pelas mesmas leis que os portugueses eram governados. Esta nação foi a mais humana, foi aquela que governou com mais doçura a suas colônias (...) Os senhores não tinham direito de vida e morte sobre seus escravos; não havia diferença na legislação do Brasil entre tal ou tal espécie de cidadãos antes de sua independência, e muito menos depois dela; a única diferença era entre quem era nobre ou plebeu; havia nobres de todas as cores, havia nobres pretos, homens de cor e homens brancos. (Anais do Parlamento Brasileiro, 27/06/1848, p. 280)
\end{abstract}

[O]s pardos, no número dos quais há pessoas de consumada instrução e muita gente de siso, não ignoram que eles não têm no Brasil as queixas que exasperaram por exemplo os homens de cor em S. Domingos (...) No Brasil, as coisas se passam muito diversamente: quer no tempo do governo absoluto, quer sob o regime constitucional, nenhuma diferença legal foi estabelecida entre os brancos e a gente de cor livre. Alguns prejuízos da educação a tal respeito, que acham origem na existência da escravatura e nas castas a que a escravatura pertence, perdem todos os dias da sua força, e cedem o campo aos triunfos da Filosofia. Não há maior iniquiidade do que confundir homem de cor com haitiano: dos homens de cor livres, muitos tem escravos, e são tão interessados como os nossos Cidadãos, em que a as idéias do feroz haitianismo não triunfem. (Aurora Fluminense, 06/04/1835, p. 3). 
Em outras palavras, deve-se ter em conta que, ao contrário da Europa, no Brasil o poder é exercido mediante dispositivos discursivos que celebram a mistura, em vez da pureza, de raças. Historiadores do Haitianismo já denunciaram $A$ Miragem da Miscigenação contida neste tipo de argumento, que não raro requer boas doses de "daltonismo social" (FERREIRA; GOMES, 2008, p. 154). A formulação da intelectualidade militar sobre este ponto é sintomática desta operação haitianista que recorre ao mito da fusão pacífica das raças (ignorando o estupro colonial e o genocídio epistêmico, por exemplo) para fundamentar a melhor capacidade brasileira de pacificar locais como o Haiti hoje. Como visto no capítulo anterior, fala-se muito em "traduzir as vantagens de uma formação multiétnica em emprego de tropa ou em eficaz atuação de civis e militares brasileiros em missões de paz" (CLAUHS, 2013, p. 101). Esta argumentação é taxativa quanto ao elo entre uma colonialidade específica e uma suposta adequação às intervenções humanitárias atuais.

Partindo-se, pois, de perspectivas de causas e efeitos, foi possível depreender que a miscigenação, ocorrida em larga escala no universo relacional brasileiro, aliada ao sincretismo religioso, à tolerância, à alteridade e à empatia, têm facilitado o respeito à diversidade de valores de outros povos - aspecto fundamental, segundo a ONU, para o labor em favor da paz em circunstâncias de adversidade. (2013, p. 108)

Isto é feito no Brasil justo no momento em que a própria intelectualidade portuguesa ataca frontalmente as bases deste discurso favorável ao lusotropicalismo colonizador. Em Racismo em Português: o lado esquecido do colonialismo, Joana Gorjão Henriques (2017) relembra que "conhecimento é poder" a fim de desmontar o mito fundacional que sustenta as teses sobre o jeitinho brasileiro de pacificação, aquele que começa pela "narrativa do colonizador benevolente" (2017, p. 18):

Como é possível que, até hoje, nunca tenha existido um museu da Escravatura em Portugal? Porque não nos é ensinado na escola que existiu um apartheid em Angola e em Moçambique, alimentado por Portugal? Porque insistimos num olhar benevolente sobre um Portugal que não hesitou em promover o trabalho escravo até 1974? Vamos perpetuar a narrativa de um colonizador que não discriminava porque se miscigenou com as populações locais, quando sabemos que essa mistura foi feita à custa do estupro, que Portugal obrigava essas pessoas a despirem-se de sua identidade africana, a mudarem de nome, a alisarem o cabelo ou a esconderem a sua língua? Até quando iremos contribuir para uma mentalidade acrítica sobre um dos fenómenos mais violentos da nossa História? Finalmente: o que é que esta 
perspectiva da brandura de olhar diz sobre nós próprios, portugueses? (2017, p. 16$17)^{291}$

Até mesmo a intelectualidade militar lusitana, hoje em dia, já avança no processo de revisão e abandono desta visão idílica sobre sua própria colonização. Tal versão fora mobilizada pelo salazarismo quando o regime autoritário do Estado Novo se encontrava isolado internacionalmente e diante de uma obstinada guerra por libertação em suas colônias ultramarinas na segunda metade do século XX. A Revista Militar de Portugal publicou artigo crítico a este ideário da "colonização híbrida" (SANTOS, 2014, p. 10) intitulado O Luso-Tropicalismo enquanto modelo ideológico da colonização portuguesa, onde enfrenta-se esta política de justificação do colonialismo tardio que foi feito mediante a adoção das teses de Gilberto Freyre.

A doutrina do luso-tropicalismo, apadrinhada pelo Estado Novo, explicava o "sucesso" da expansão portuguesa pelo carácter cristocêntrico do povo português, pela predisposição do português para a colonização híbrida e escravocrata, e pela capacidade que mostrou para se unir aos povos das regiões tropicais através da miscigenação e interpenetração cultural, assente em três abordagens: miscigenação (facilitada pela apetência para a mobilidade e aclimatabilidade), reciprocidade cultural e "missão" evangelizadora. Ainda, postulava como verdadeira e positiva a realidade pluricontinental e multirracial da nação portuguesa (CABRAL, 2010, p. 11), e apresentava o colonialismo português como o mais filantrópico de todos, com base no primado da efetiva integração (por parte do colonizador) de fatores de diferenciação (sociais, raciais, culturais, políticos, económicos, gastronómicos, educacionais, de indumentária, princípios de medicina tradicional, etc.) (...) O lusotropicalismo nunca foi incorporado plenamente no discurso oficial, contrastava em grande medida com a prática de gestão colonial, e o regime salazarista só usou o luso-tropicalismo para justificar a persistência do sistema colonial quando se intensificaram as pressões externas. Não passou de uma aspiração, de um mito, "inventado de costas voltadas para os factos históricos e para a realidade concreta" (CASTELO, 1999, p. 140), que "forneceu ao regime um sustento ideológico de grande rentabilidade política e a que grande parte da intelligentzia portuguesa se rendeu acriticamente, ou por desconhecimento da situação do terreno, ou por conveniência e conivência política" (PEREIRA, 1998, p. XXXI). Tanto é que, acabou-se a submissão a um regime político colonial, mas continuaram a persistir formas de colonização económicas e ideológicas. (SANTOS, 2014, p. 10)

Não obstante tais movimentos de "contramemória" (FOUCAULT, 1979, p. 33), o discurso sobre a característica distintiva, mais humana, do modelo brasileiro

\footnotetext{
291 Ainda que o livro de Henriques (2017) seja baseado em estudos de caso sobre as colônias africanas, a autora argumenta na introdução à edição brasileira que "a publicação deste livro no Brasil é, de certa forma, um passo natural”, já que "[e]sta relação de invisibilidade, de silenciamento sistemático, de discriminação activa da população negra em Portugal tem as suas raízes no processo da colonização e da escravatura, do qual o Brasil também ainda hoje sente os efeitos" (2017, p. 9). Sobre o estupro como mecanismo de colonização e alguns de seus efeitos psíquicos sobre os povos colonizados, ver também Fanon (2005, p. 293-298).
} 
de intervenção insiste em recorrer à herança colonial para erigir sua própria defesa, assim como os discursos sobre Haitianismo no século XIX já o faziam com relação ao sistema escravista nacional. Neste sentido, terminam sendo mais coloniais do que os próprios colonizadores. Em artigo intitulado Os Impactos da Formação Multiétnica na Liderança Militar Brasileira em Missões de Paz, o tenente-coronel Ândrei Clauhs (2013), doutor em ciências militares, elabora tal ponto com tamanha precisão que é preciso analisá-lo mais detidamente, uma vez que seu texto ativa com exatidão a prática discursiva em questão. Entendido enquanto genealogia, o Haitianismo reemerge, assim, nesta narrativa que relaciona o escravista protetor e já miscigenado com o interventor militar possuidor de "inteligência cultural" no Haiti (CLAUHS, 2013, p. 107). Um jogo de relações entre o que poder-se-ia chamar de discurso haitianista sobre uma escravibranda e uma intervenbranda. Ou, simplesmente, de Paz Haitianista:

Estudos acerca da formação multiétnica do povo brasileiro encontram amparo no consenso de autores nacionais e estrangeiros. De suas obras pode-se inferir que o Brasil se constituiu por meio da mestiçagem, da fusão de três etnias fundamentais: o branco, o negro e o índio (ORTIZ, 2006, p. 19). Corroborando esse pensamento, Sérgio Buarque de Holanda (1995) em sua obra Raízes do Brasil, remete o leitor à plasticidade social dos próprios colonizadores portugueses, que, à época do descobrimento do Brasil, já eram mestiços e, portanto, não tiveram problema algum em se misturar aos gentios da nova terra (HOLANDA, op. cit., p. 53).

Indo mais adiante, esse mesmo autor mostra que a mesma plasticidade social pôde ser observada, já na sociedade colonial brasileira, ao afirmar que o escravo negro não era uma simples fonte de energia braçal. Freqüentemente, suas relações com os senhores de engenho oscilavam do status de dependente para o de protegido e, algumas vezes, até mesmo de solidário e confidente. "Sua influência penetrava sinuosamente o recesso doméstico, agindo como dissolvente de qualquer idéia de separação de castas" (op. cit., p. 55).

Essas assertivas permitem que se chegue a outra, igualmente importante, de que a miscigenação, a mistura que produziu o mestiço, ocorreu em larga escala no solo brasileiro (DA MATTA, 2004, p. 22) produzindo um povo híbrido e gregário. Em concordância com essas idéias, no livro Casa-Grande \& Senzala, Gilberto Freyre (2006) abordou a visão de uma sociedade escravocrata, na qual as três etnias fundamentais presentes, embora lapidadas por práticas culturais diversas, atenuaram suas diferenças por meio da hibridização e da miscibilidade étnica, o que significou não só a mistura de cores de peles, mas também um intercâmbio de culturas que passaram a viver em conjunto, legando para os tempos modernos a capacidade de adaptação do povo brasileiro, seja em terrenos físicos diferentes, seja em ambientes sociais distintos.

Assim, é possível inferir que, em meio a esse triângulo social inicial das etnias, o ambíguo, o híbrido, passaram a ser interpretados como dados positivos da mestiçagem; uma síntese do melhor que pode existir no negro, no branco e no índio. (CLAUHS, 2013, p. 102 - Negrito adicionado) 
Assim, adaptando os alertas de Foucault (1979; 2006) para o caso em questão, vê-se a gravidade do que está em jogo em tais formulações sobre a identidade brasileira. Após enfatizar insistentemente a "fusão cultural" que resulta em "solidariedade multiétnica ou multicultural", esta leitura particular de clássicos da sociologia e antropologia nacionais "apresenta como sendo 'o jeitinho brasileiro', um estilo profundamente original e brasileiro de viver" (CLAUHS, 2013, p. 102) como fundamento de uma melhor política bélico-cultural, "a partir da exploração dos principais caracteres evidenciados pela formação multiétnica do povo brasileiro, que facilitam o desenvolvimento da liderança multicultural" (2013, p. 103). Não se trata apenas de aproveitar heranças históricas, mas de promover ativamente um processo de formação de comandantes militares pós-coloniais.

[S]endo a liderança também classificável no domínio afetivo dos objetivos educacionais, é passível de ser desenvolvida por meio do processo ensinoaprendizado, em que o treinamento multicultural servirá como guia de ação para o desenvolvimento de líderes (COSTA, 2009). Desse modo, essa práxis da liderança multicultural (ROBBINS, 2005) pode oferecer aos instrutores do CCOPAB uma ferramenta que permite remodelar o treinamento por meio de uma "cultura multivalenciada linguisticamente e na qual os indivíduos possam conceber a identidade como uma montagem polivalente de posições de sujeitos contraditórios". (MCLAREN, 2000) (2013, p. 103)

Não se tratam de trechos extraídos ao acaso ou retirados de seu contexto, mas exemplos que se referem ao ponto central de uma argumentação (decerto repetitiva) que insiste sobre o nexo entre "as raízes de nossa identidade", como diria Foucault (1979, p. 35), e as tecnologias de poder postas em prática sobre o Outro, descrito como culturalmente diverso. É salutar que apesar de tanta ênfase na miscigenação racial, o autor afirme que estas cheguem a uma "fusão" ou "síntese" racial de um sujeito brasileiro ou "povo brasílico" (CLAUHS, 2013, p. 102; 104). Outros enunciados acerca da "diplomacia cultural" dos soldados brasileiros também reivindicam uma "essência e identidade" próprias como sendo o "diferencial cultural", que seria a "arma secreta" dos militares deste país (CARVALHO, 2017, p. 49). Ora, é justamente aquilo que é transmitido como síntese, fusão ou essência da identidade brasileira que a genealogia tem a obrigação de retalhar, fazendo "aparecer todas as descontinuidades que nos atravessam" 
(FOUCAULT, 1979, p. 35) para melhor combater esta política racial e militar, que opera tanto dentro quanto fora das fronteiras nacionais. ${ }^{292}$

Não resta dúvidas sobre os efeitos de poder desta prática discursiva que cria - e recria - um sujeito brasileiro, ao mesmo tempo híbrido e sintetizado, capaz, segundo o discurso do Haitianismo, de gerenciar uma escravidão racializada, porém benévola, e um intervencionismo militar poderoso, mas devidamente humanizado. Assim como Foucault percebe que primeiro faz-se experimentos sobre os corpos daqueles considerados loucos para em seguida teorizar-se sobre o que é a loucura, neste caso pratica-se a brutalidade escravista e militarista para, em seguida, construir-se uma prática pedagógica acerca destes sujeitos e objetos do poder. É sobre a importância deste tipo de manifestação discursiva de afetividade, como as acima descritas (que apresentam os "senhores de engenho" na forma de um sujeito "solidário e confidente" dos escravizados), que Castro-Gómez (2007) chama atenção para as contribuições de Foucault para a análise da colonialidade do poder. Em outras palavras, deve-se indagar as "tecnologias do eu", ou seja, "práticas que afetam a produção de subjetividade" onde se jogam a "corporalidade, a afetividade, a intimidade" e que são perpassadas por "fluxos de crenças e desejos" (2007, p. 165-166). Tecnologias patenteadas com orgulho e já passíveis de exportação.

[O] entendimento do sofrimento alheio, aliado ao espírito de cooperação na busca por soluções criativas, ajuda a traduzir o "jeitinho brasileiro" em cientificismo. Jeito esse que, conforme se pôde verificar, já está presente no dia-a-dia do brasileiro, haja vista que a atividade que desempenham nas favelas do Haiti, por exemplo, executam também nas comunidades brasileiras, como no Complexo do Alemão, no Rio de Janeiro, o que permite a identificação com esse tipo de atividade (...) bem como a possibilidade de estender os estudos realizados a outros países que atuam sob a égide das Nações Unidas, com foco no caráter nacional de sua gente, que lhes confere identidade própria e peculiaridades que certamente se enquadram no contexto das missões de paz, com vistas ao melhor desempenho quando em funções de liderança. (CLAUHS, 2013, p. 104; 108)

O Haitianismo, assim, não está preso ao século XIX. E, menos ainda, às fronteiras nacionais, sejam elas haitianas ou brasileiras. Como prática discursiva

\footnotetext{
${ }^{292}$ Cumpre notar que a mera evocação das três raças por si só não leva automaticamente a uma ativação da colonialidade do poder. Por isso, é importante uma análise extensiva e detalhada do regime discursivo em que opera. Um exemplo contrário, que representa indubitavelmente uma postura decolonial e que ainda assim invoca a mesma identidade racial tripartite, pode ser encontrado na famosa canção de autoria de Mauro Duarte e Paulo César Pinheiro, intitulada justamente $O$ Canto das Três Raças (1976), eternizada pela voz de Clara Nunes. Nesta canção de protesto, a evocação racial serve ao propósito de afirmar as descontinuidades que nos atravessam, denunciando justamente aquilo que as versões românticas da miscigenação buscam ocultar.
} 
que cria as condições de possibilidade, o conhecimento e as próprias tecnologias para o exercício do biopoder pós-colonial ele segue presente em emergências e ativações múltiplas. Entendidas por meio de análises genealógicas, tais irrupções podem ser conectadas pelos feixes de relações que estabelecem entre si, mesmo na forma de inversões, deslocamentos e modificações que impedem a postulação de uma continuidade linear e teleológica. Como feito, por exemplo, pela inspiradora análise foucaultiana de Malaguti Batista (2014) sobre os "discursos que matam", ao mostrar dois tempos de uma história, que já tratava do Haitianismo como parte dos “medos impressos" por ela estudados (2014, p. 169).

A presente investigação - tributária em grande medida da sua - espera ter mostrado, mediante a análise de duas histórias num só tempo, a possibilidade e o risco de reativações destes dispositivos. Nada garante que o Haitianismo, enquanto prática de poder, continuará a emergir, assim como não está pré-determinado que seu fim tenha definitivamente chegado por algum motivo transcendental ou metahistórico. É a própria política, seus jogos de forças, os intermináveis combates da "guerra continuada por outros meios" (FOUCAULT, 2006, p. 30) que decidirão o quão longe esta genealogia poderá chegar.

A próxima seção destina-se a contribuir com a resistência a este exercício do poder - de biopoder pós-colonial - a partir da abordagem destas práticas discursivas, definitivamente como Haitianismo, incluindo aquelas de cunho estritamente bélico. São recuperados trabalhos que já iniciaram este caminho e levantadas interrogações sobre que tipo de sucesso tem sido alcançado. Questionamentos que não têm sido feitos o suficiente e que podem, com sorte, ensejar novas análises hipercríticas das relações entre poder e saber estabelecidas pelo alegado modelo brasileiro de gerenciamento de pessoas e locais identificados, no discurso da paz haitianista, por sua negritude, pobreza, inferioridade civilizacional ou subdesenvolvimento. Pessoas que são vigiadas, mas também protegidas, como alega Clauhs (2013, p. 102) com relação ao "escravo negro" no Brasil colonial. E que hoje são objeto da Responsabilidade de Proteger, mesmo quando não tenham solicitado tal proteção.

\section{A MINUSTAH como Haitianismo}

Não é coincidência que o intelectual militar que expõe a genealogia do Haitianismo com mais perfeição seja o mesmo que termine seu argumento 
defendendo a utilidade deste tipo de operação de subjetivação de "a-gentes" (CLAUHS, 2013, p. 109) treinados para atuar em locais como o Haiti também para fins de pacificação doméstica no Brasil. Em outras palavras, os jogos de relações temporais que levam do século XIX ao XXI também produzem elos geoespaciais entre a militarização das favelas cariocas e as de Porto-Príncipe, mediante a produção de sujeitos capacitados para missões de controle de populações caracterizadas por sua alteridade, em meio às modalidades enunciativas que emergem na genealogia do Haitianismo.

Por isso, esta tese se apresenta como válida até mesmo para que sejam aprofundadas novas pesquisas dentro do próprio País ou fora dele, por instituições que se ressintam de estudos sobre interculturalidade e ethos, por exemplo, como é o caso do exercício de liderança dos "a-gentes" que atuam nas Unidades de Polícia Pacificadora (UPP) na cidade do Rio de Janeiro, e que certamente apresentarão desempenho mais satisfatório na implantação da paz ao conhecerem e perceberem o modo de ser e de agir dos seres humanos que habitam as comunidades locais. (CLAUHS, 2013, p. 109)

De fato, as comparações entre os modelos de pacificação empregados por tropas brasileiras no Haiti e os programas de segurança pública fluminenses são comuns. Não faltam exemplos de reportagens que apontaram o intercâmbio de experiências entre os dois casos, assim como foram inúmeras as vezes em que se empregou a palavra "laboratório"293 para descrever (mediante uma metáfora científica) o desenvolvimento de saberes e tecnologias que a intervenção militar no Haiti poderia trazer para o Rio de Janeiro - e deste ente federativo para o resto do país. Orgulhosamente, generais, diplomatas, secretários de segurança, chefes de polícia, jornalistas e acadêmicos afirmaram repetidamente que as UPPs cariocas haviam aprendido lições com a ocupação do Haiti ou, inversamente, que a MINUSTAH havia se beneficiado da expertise galgada por décadas de

\footnotetext{
${ }^{293}$ Dentre outras, ver as declarações do então embaixador brasileiro no Haiti, Igor Kipman, que expunha sem rodeios, em 2012, que o "Haiti é um laboratório para nós, nas áreas militar e civil, de governo e de sociedade civil". Disponível em (acesso em Novembro/2018):

http://g1.globo.com/mundo/noticia/2012/02/haiti-se-tornou-laboratorio-para-o-brasil-diz-

embaixador.html. Sobre o uso do Rio de Janeiro como "laboratório para o Brasil", ver as declarações do general Walter Braga Netto ao anunciar para a imprensa o início da intervenção militar federal no estado em 2018. Disponível em (acesso em Novembro/2018):

https://g1.globo.com/rj/rio-de-janeiro/noticia/autoridades-detalham-medidas-da-intervencaofederal-o-rio-de-janeiro.ghtml. Para uma crítica pós-colonial ao discurso sobre laboratórios em intervenções internacionais, ver Hönke e Müller (2016), especialmente o capítulo 4, intitulado "Beyond the laboratory thesis".
} 
militarização doméstica. Muitos não se entendiam sobre qual a relação de causa e efeito correta a ser apontada em tais nexos. ${ }^{294}$

$\mathrm{O}$ que escapou à maioria dos observadores e comentaristas, incluindo os críticos, é que esta causalidade circular indica a emergência de expedientes discursivos já ativados pela formação discursiva do Haitianismo desde muito antes. $\mathrm{O}$ tropo do aprender para não repetir (uma revolução de negros escravizados) faz parte da mesma genealogia do experimentar para reproduzir, que usa o Haiti para o ensaio de políticas de controle bélico e cultural desde a inauguração da MINUSTAH. São relações que ajudam na captura da colonialidade do poder envolvida em tais procedimentos, que vão e voltam transpondo modelos entre metrópoles e colônias; entre países que comandam e aqueles que são alvos de intervenções. Estes bumerangues são apontados por Foucault (2006) em seus estudos sobre a emergência do discurso de "pureza da raça", quando surgiria um "racismo de Estado: um racismo que uma sociedade irá exercer sobre si mesma" (2006, p. 74).

\begin{abstract}
Nunca devemos nos esquecer que a colonização, com as suas técnicas e as suas armas políticas e jurídicas, transpôs obviamente modelos europeus para outros continentes, mas conheceu também numerosos efeitos de retorno nos mecanismos de poder no Ocidente, sobre os aparelhos, as instituições e as técnicas de poder. Houve toda uma série de modelos coloniais que foram trazidos para o Ocidente, o que fez com que este pudesse praticar também sobre si mesmo qualquer coisa como uma colonização, um colonialismo interno. (2006, p. 114)
\end{abstract}

Portanto, admitindo-se a genealogia do Haitianismo como pertinente, é possível redimensionar estes movimentos circulares - de circulação dos modelos de exercício do poder - que estão presentes nos enunciados que apregoam o vínculo entre UPPs e demais pacificações domésticas (como as realizadas pelas próprias Forças Armadas, nos Complexos da Maré e do Alemão) com a pacificação exterior promovida pela MINUSTAH nas favelas da capital haitiana, especialmente nas

\footnotetext{
${ }^{294}$ Dentre muitas, ver reportagem que afirma ser a MINUSTAH uma inspiração paras as políticas empregadas no Rio de Janeiro. "A PM visitou o Haiti para ver como se fazia, e assim surgiu o conceito de UPP. O Exército tem usado as experiências do Haiti no Complexo do Alemão e na Maré", diz um coronel entrevistado. Disponível em (acesso novembro de 2018):

https://www.dw.com/pt-br/miss\%C3\%A3o-no-haiti-torna-brasil-refer\%C3\%AAncia-emtreinamento-de-for\%C3\%A7as-de-paz/a-18141833. Ver também a página oficial das UPPs, que propõe uma causalidade inversa, na qual são os modelos do Rio de Janeiro que seriam exportados para o Haiti. Disponível em (acesso em novembro 2018):

http://www.upprj.com/index.php/acontece/acontece-selecionado/prefeito-de-cite-soleil-visita-uppfazendinha-no-complexo-do-alemaeo/CPP. Para trabalhos acadêmicos que exaltam este intercâmbio, ver Kenkel (2011) e Souza Neto (2012).
} 
agora conhecidas Cité Soleil e Bel-Air. Com a libertação dos saberes subjugados referentes ao Haitianismo é possível dar-se conta que já na época de sua primeira irrupção, no início da era pós-colonial brasileira, a grande tarefa (auto)imposta aos construtores da nação era justamente a de realizar uma "expansão para dentro" do próprio Império (MATTOS, 2005, p. 26). Uma espécie de colonialismo doméstico que visava "dominar as demais nações" (2005, p. 26), não brancas, existentes naquele território e que valeu-se do Haitianismo justamente como uma das formas de pacificar as revoltas que ameaçavam a frágil unidade política e territorial do novo Estado, como mostraram Freitas (2005), Gomes e Soares (2002) e Bezerra Neto (2001) em relação à Cabanagem, no Pará, por exemplo.

Recentemente, começaram a surgir análises críticas, ou mesmo hipercríticas, da MINUSTAH que abordam justamente esta circularidade entre os projetos de pacificação interiores e exteriores brasileiros, especialmente entre as UPPs do Rio de Janeiro e a força de estabilização do Haiti. Markus-Michael Müller (2016) oferece uma poderosa crítica contra o discurso de "laboratórios", especialmente focada na romantização do "jeito brasileiro" de comandar operações de paz. Mesmo que seja apenas um capítulo de um livro que ele mesmo organiza, ${ }^{295}$ seu trabalho oferece uma contribuição inestimável para o debate, uma vez que insere aquilo que identifica como estratégias de contrainsurgência pós-coloniais dentro dos propósitos da paz liberal. Sua conclusão se aproxima da análise levada a cabo pela presente investigação. Ainda que por caminhos distintos, ele afirma que:

$[\mathrm{P}]$ ostcolonial countries like Brazil have entered the global policing lab by using other postcolonies, in this case Haiti, as veritable workshops for the testing and refining of their own 'domestic' policing approaches. In this regard the findings of this chapter not only highlight the need of decentring the "laboratory model" (Bilgin, this volume). They also challenge the dominant, and overly positive, assessments regarding the Brazilian MINUSTAH experience, and the 'Brazilian way of peacekeeping'. Far from being less 'coercive', 'imperialist', or more culturally 'sensitive', this chapter has shown that Brazil's MINUSTAH experience created a transnational field of urban counterinsurgent order-making through pacification-driven policing of the 'urban other', in Haiti and at home. And like all forms of liberal counterinsurgency, these practices are marked by the unresolvable contradiction between "illiberal methods and liberal discourse, between bloody hands and honeyed tongues, between weapons of war and emancipatory hyperbole". (2016, p. 88-89)

\footnotetext{
${ }^{295}$ MÜLLER, Markus-Michael; HÖNKE, Jana (Eds.) The Global Making of Policing: postcolonial
} perspectives. London and New York: Routledge, 2016. 
Sem o Haitianismo, contudo, o alcance da crítica de Müller (2016) fica mais restrito do que poderia ser, além de não perceber que a especificidade própria deste dispositivo de poder - o tão propalado hibridismo - existe de fato, não sendo mero adereço simbólico destinado a encobrir as mesmas práticas da paz liberal, como sua análise supõe. Pois é justamente o hibridismo que pode explicar aquilo que ele vê como a "contradição irresolúvel”, acima citada. Müller (2016) faz breves comparações históricas com as práticas policiais e militares brasileiras de outras épocas. Mas caso fizesse uso das armas que a genealogia do Haitianismo proporciona, seu estudo poderia avançar mais nos paralelos com o histórico de militarização do Rio de Janeiro e dar-se conta que os nexos entre as políticas de contrainsurgência vão muito além da estratégia chamada de Clear-Build-Hold $(\mathrm{CBH})$, que está no centro de sua argumentação.

Desconhecendo a problemática do Haitianismo (especialmente suas fontes primárias), Müller (2016) é obrigado a aceitar acriticamente as posições altamente questionáveis do historiador brasilianista Thomas Holloway (1997), para quem o padre, ministro da Justiça e Regente do Império Diogo Antônio Feijó era um defensor "do que hoje chamamos direitos humanos" e que, portanto, não merecia ser chamado de "autoritário arbitrário" (1997, p. 94) por sua atuação no fatídico ano de 1831, quando surge o conceito de Haitianismo. ${ }^{296}$ Isto reduz o problema e as comparações históricas a uma chave estritamente bélica, deixando de lado as implicações (bio)políticas mais amplas que tais estratégias envolvem. Em outras palavras, deixa de ver que não se trata somente da herança de uma cultura policialmilitar racista e elitista, afeita à contrainsurgência, mas também de uma maneira própria de produção do Estado pós-colonial. ${ }^{297}$

Supõe ainda que o tipo de "militarismo humanitário" (GREENBURG, 2013, p. 60), que ele entende corretamente como uma herança da participação brasileira na MINUSTAH, seja um legado absoluto cuja continuidade no tempo é dada como

\footnotetext{
${ }^{296}$ Como visto no capítulo 4 , já na época havia muita discordância quanto ao modus operandi de Feijó a frente do ministério da justiça e da Regência. O Jurujuba dos Farroupilhas, por exemplo, busca desconstruir sua fama de filantropo, que é reproduzida por parte da historiografia sobre ele. ${ }^{297}$ Müller (2016), apesar do trabalho de qualidade que apresenta, é induzido por sua confiança em fontes secundárias, a outros erros de interpretação. É assim que ele acredita que o slogan Braço Forte, Mão Amiga, estampado nas instalações do BRABAT em Porto-Príncipe tenha sido algo inventado por razão da operação no Haiti, quando sabe-se que se trata de algo bem mais antigo, que remonta à redemocratização do Brasil (a frase surgiu em 1992), quando o Exército buscava alterar sua imagem junto à população brasileira. Ver, a respeito (acesso em Novembro/2018): http://eblog.eb.mil.br/index.php/menu-easyblog/exercito-brasileiro-braco-forte-mao-amiga.html.
} 
certa. Assim, deixando de avançar em sua própria hipótese, ele não vislumbra que a falência do projeto das UPPs aconteceria em paralelo ao fim da própria MINUSTAH, mesmo que tenha percebido que o início daquela tenha coincidido com a primeira grande operação de $\mathrm{CBH}$ em Cité Soleil. Ao entender a MINUSTAH como Haitianismo, poder-se-ia perceber que não foi apenas o retorno para solo doméstico de uma prática refinada no exterior, mas de um jogo de legitimações mútuas que estava em cena. Não uma repercussão dos acontecimentos no Haiti, mas uma apropriação para fins de política local dos eventos narrados sobre lá e vice-versa. Caso contrário, o fim de uma não levaria ao abandono quase imediato da outra política pacificadora, admitindo-se que não se tratou de mera coincidência. O Haitianismo elucida melhor este fim mútuo.

Com efeito, há um emaranhado de relações mais intenso entre os discursos humanitários e a duração das práticas biopolíticas na genealogia do Haitianismo. A suave retórica racial de respeito aos "pardos" de Evaristo da Veiga teve seu auge 1835, mas a escravidão enquanto regime continuou por mais de meio século depois, pontuada por paliativos como as Leis Eusébio de Queirós (1850), do Ventre Livre (1871) e a dos Sexagenários (1885). No Rio de Janeiro, o término de facto das UPPs e sua propaganda de "nova cultura de métodos policiais mais pacíficos" (SILVA, 2012, p. 181) deu lugar a uma intervenção militar federal em 2018, que abandona em parte a linguagem afável, afirmando ser necessário o "sacrifício dos poderes constitucionais, das instituições e, eventualmente, da população" (INFORMEX, 2018, p. 1). Outra vez mais, o humanismo acaba, mas o militarismo racializado prossegue, pontuado por novos planos-piloto, sob novas siglas, indicativas de uma pretendida humanização, mesclada com ameaças de atos de exceção.

Müller (2016) deixa de perceber estes bumerangues, transições e deslocamentos mútuos entre os discursos pacifistas e os abertamente homicidas, supondo que os primeiros sempre prevaleçam, como se fossem simplesmente uma máscara retórica para uma prática policial-militar que operaria de forma contrária. No entanto, os jogos de relações são mais complexos, pois as práticas discursivas humanitárias se alternam com as mais explicitamente cruéis (as que ameaçam "sacrificar" a população, que apelidam seus blindados de "caveirão", dentre outras morbidades). Ao tratar como simples verniz simbólico aquilo que é parte de um dispositivo mais sofisticado - do "próprio discurso enquanto prática" (FOUCAULT, 2016, p. 56) - Müller (2016) deixa de perceber o ponto nevrálgico 
deste exercício do poder, que é o fato de que nesta prática discursiva uma modalidade enunciativa não funcionaria tanto sem a outra: seu poder advém justamente desta ambivalência. Fosse mera mascarada, hipocrisia ou ideologia, entendida como falsa consciência, um discurso que disfarça a realidade, seria mais fácil se contrapor a ele. Porém, o dispositivo de poder em operação - nas operações da MINUSTAH e UPPs - é um tanto mais complexo que isso: entendidas como Haitianismo, percebe-se que seu poder está justamente no hibridismo real de suas formulações discursivas e táticas.

A própria noção de Policiamento de Proximidade é denunciada como “perversa" (PRADAL, 2013) por críticos das atuais políticas de pacificação do Rio de Janeiro justamente pela mesma ambivalência entre afabilidade e violência extrema. Ela encontra outras emergências relevantes, caso vistas pela genealogia do Haitianismo. Na mesma edição em que denuncia a suspensão de garantias constitucionais “em virtude da existência do Haitianismo", o Pão D'Assucar faz um chamado contra o "perigo em que estivemos de ver nossas esposas e filhos mortos desapiedadamente por bárbaros Africanos", conclamando as autoridades a "estabelecer uma Polícia ativa e vigilante, que observe com cuidado todos os passos que os Africanos derem". O editor afirma ser preciso "termos uma força armada suficiente, que pela sua disciplina e gente escolhida de que se compuser, nos inspire confiança e aos escravos infunda terror". ${ }^{298}$ Deste modo, lendo-se a MINUSTAH e as UPPs como Haitianismo, pode-se captar mais habilmente as rápidas transições entre os discursos da militarização humanitária para o da militarização pura $e$ simples. Ambas as formas, no entanto, almejam o incremento da vigilância e controle seja agressiva ou amigavelmente.

Deste modo, entender as complexas formas (híbridas, ambivalentes, circulares) que produzem a militarização pós-colonial como cenas na genealogia do Haitianismo equipa aqueles que pretendem - ou precisam - resistir a seu poder diariamente. Estar-se-ia melhor preparado para lidar com a transição incorporada pela figura do General Augusto Heleno, por exemplo, celebrado como comedido no uso da força no Haiti por Kawaguti (2006) e Seitenfus (2016), mas que também afirma que "os bandidos perderam o respeito" e que "o sujeito que estiver com

${ }^{298} \mathrm{PA}, \mathrm{n}^{\circ} 27$ de $07 / 04 / 1835$, p. 3. 
armas (...) precisa ser alvejado, para que vidas sejam economizadas". ${ }^{299}$ Afinal, na formação discursiva do Haitianismo, é em nome da vida que se justifica a morte. Como visto no capítulo 3, o jornal O Cruzeiro usava ipsis litteris a mesma formulação, ao esbravejar contra os negros e escravizados que estariam "perdendo o respeito" ao abusar da liberdade, transformando-a em "licença". Seu clamor por um endurecimento do regime escravista também era feito em nome do "bem da humanidade".

O tratamento dispensado ao Outro pelo Pão D'Assúcar em 1835, ao classificá-los como "bárbaros africanos", evoca o imaginário de barbarismo e inferioridade civilizacional usualmente direcionado ao Haiti hoje em dia (SCARAMAL, 2006), sendo reativado pelo general Heleno, que declara à imprensa sem meias-palavras: "chegou a hora de formar cidadãos e não criar funkeiros". 300 A cultura do Outro (favelado, negro) é novamente contraposta aos direitos civis dos bons brasileiros. $\mathrm{O}$ mesmo general (criador do modelo brasileiro de atuação militar no Haiti) critica aquilo que chama de "ideologias contaminadas", reativando as práticas discursivas da Mensagem ao Trono de 1835 que fala de "doutrinas subversivas", isto é, “doutrinas haitianas”. As inversões no seio da formação discursiva do Haitianismo precisam estar presentes. O mesmo governador do Rio de Janeiro, Sérgio Cabral Filho, celebrado pela imprensa por criar o modelo pacificador mais humano das UPPs em 2008, também afirmava em 2007 que as favelas eram "fábricas de produzir marginal". ${ }^{301}$ Ao defender o aborto para mães faveladas como forma de diminuir a violência, ele racializava explicitamente seu discurso, além de identificar a pobreza como fonte de perigo em si, como também realizado pelo policial brasileiro da MINUSTAH : "existem "dois brasis", um de padrão de países nórdicos, como a Suécia, e outro com nível de pobreza comparável

\footnotetext{
${ }^{299}$ Os castigos sumários ou execuções extrajudiciais também fizeram parte da primeira emergência do Haitianismo, como visto pelas denúncias e relatos do Bacorinho e pela afirmação do Nova Luz sobre "pena de morte para Haitianismo", mesmo que este "crime" nunca tivesse constado do Código Criminal de 1830. Mas nem por isso deixou-se de torturar e assassinar inimigos internos em seu nome. Desnecessário lembrar que ser morador de uma favela também não é um crime, mesmo que durante as incursões policiais e militares esta condição acabe levando, muitas vezes, à morte de inocentes.

${ }^{300}$ Estas declarações do general Augusto Heleno Ribeiro Pereira estão na entrevista à Coluna do Fraga, de 02/02/2018, do portal Notícias R7, disponível em (acesso em abril/2018): https://noticias.r7.com/prisma/coluna-do-fraga/intervencao-no-rio-tem-que-ser-curta-econtundente-diz-general-20022018.

301 Ver reportagem completa em (acesso em dezembro/2018):

https://www1.folha.uol.com.br/fsp/cotidian/ff2510200701.htm.
} 
a países miseráveis africanos". ${ }^{302}$ Doutrina errada, cor da pele errada, cultura errada: eis os inimigos que o Haitianismo precisava - e precisa - domesticar, estabilizar, pacificar, normalizar. E também exterminar ou mesmo impedir que nasçam.

Ler a MINUSTAH e as UPPs como Haitianismo permite desconstruir os regimes de verdade que se criaram em torno destas políticas de (in)segurança. Sem o Haitianismo é possível, ou até fácil, aceitar a benignidade do discurso emanado dos próprios enunciadores deste 'modelo brasileiro'. Por outro lado, com o Haitianismo em conta, é difícil não se dar conta que o propalado sucesso não diz respeito somente às operações em curso no Haiti ou nas favelas cariocas hoje em dia, mas que faz parte de dispositivos de produção de um sujeito pós-colonial cuja função é ser mais eficiente na tarefa de estabilizar, conter e gerir o Outro, preventivamente se preciso, dado que a raça e a classe social deste justificam por si sós a necessidade da reafirmação da soberania e da governamentalidade, ora via militarismo humanizado, ora sem humanização alguma.

Não se trata de negar o sucesso, nem os elos com o Rio de Janeiro, mas de ver os perigos envolvidos em tais manifestações. Na verdade, trata-se de uma formação discursiva que logra se estabilizar (mesmo que provisoriamente) justamente porque circula em diferentes espaços e, assim, produz efeitos de poder que se cristalizam. Portanto, seria um erro negar o sucesso, pura e simplesmente. Por outro lado, celebrá-lo acriticamente ou reproduzi-lo como forma de resgate que dê novo fôlego à razão humanitária, é outra coisa. Isto sim precisa ser contestado.

Assim, colocando-se de ponta-cabeça os discursos sobre a MINUSTAH analisados nesta tese, percebe-se que não se pode partir deles, como desejam seus proponentes, como se fossem uma inovação; menos ainda aceitar que exista uma verdadeira unidade neste 'modelo' atual: é preciso, pois, resistir a esta sugestão e tratar de fazer a arqueologia desta formação discursiva para ver que as três modalidades enunciativas abordadas no capítulo 5 são, elas mesmas, expressões de Haitianismo. Por meio de uma genealogia destas práticas discursivas, elas deixam de ser novidades (benignas) e passam à condição de re-emergências no presente das

\footnotetext{
302 Sobre a "securitização do subdesenvolvimento", que invariavelmente apela à comparações com a África, Duffield (2007) comenta de maneira apropriada à declaração de Cabral Filho: "It not only fosters fear and unease, it tends to divide the continent from the rest of the world, favours policies of containment and is encouraging the militarization of the continent" (2007, p. 4).
} 
práticas de subjetivação deste sujeito brasileiro que o domina o Outro, a ameaça haitiana, o favelado haitiano, ou carioca, mas que se parece com aquele, assim como o Complexo do Alemão, que é sempre assemelhado à Cité Soleil ou Bel-Air. Em suma, ler a MINUSTAH como Haitianismo revela a reiterada produção de um sujeito sociorracialmente híbrido como o único capaz de gerir os desafios próprios ao mundo pós-colonial. O regime de verdade da MINUSTAH, deste modo, só é viável porque existe a formação discursiva do Haitianismo como condição de possibilidade para o exercício de sua colonialidade e biopoder. Portanto, não existe humanitarismo pós-colonial, como modelo inovador; existe Haitianismo, como prática de gestão sociorracial.

É como Haitianismo que se deve entender a normalização do Outro liderada pelos dois pacificadores mais famosos desta genealogia: o Duque de Caxias e o General Heleno. Houvesse abordado o Haitianismo em seu estudo sobre a Polícia no Rio de Janeiro do século XIX, quiçá o próprio Holloway (1997) e seus leitores poderiam ter uma visão diferente sobre os acontecimentos e atores daqueles anos repletos de conflitos. O regente Feijó não é o único ostensivamente humanizado nesta narrativa: o retrato do jovem Luís Alves de Lima e Silva (futuro Duque de Caxias) pintado por Holloway (1997, p. 98-100) é tão romântico como aquele que Kawaguti (2006) faz de Heleno. Até nesta obra do historiador brasilianista (que apresenta-se como crítica e reivindica Foucault em sua introdução) Caxias aparece como um herói desde 1831, quando ainda sob a patente de major de polícia no Rio de Janeiro, sufocou sua primeira revolta "a ferro e fogo", em uma narrativa que legitima amplamente suas ações militares de exceção contra oponentes políticos, negros e escravizados na Corte Imperial (HOLLOWAY, 1997, p. 99).

Alçado ao posto de comandante da Polícia Militar do Rio de Janeiro em $1832,{ }^{303}$ ele seguiu exercendo este cargo até 1839 . Vê-se, assim, que o Haitianismo e a atuação de Caxias - o pacificador dos Outros - foram notadamente

\footnotetext{
${ }^{303}$ Em 1831, diante da crise política na capital do Império e da luta intensa pelo poder, os Liberais Moderados criaram uma força armada de tipo pretoriano (sob comando exclusivo do então ministro da Justiça, Diogo Feijó), denominada Corpo de Guardas Municipais Permanentes, que deveria garantir a ordem (política e social) na Corte, já que algumas unidades militares eram fiéis a outras forças políticas (Exaltados e Restauradores), havendo episódios e boatos constantes sobre sedições e motins. Os Guardas Municipais, oficializados somente no mês de outubro, mas já atuantes desde antes, eram compostos e pagos por comerciantes e proprietários do Rio de Janeiro. Foram responsáveis por ameaças ao próprio Parlamento, caso não aprovasse as medidas do Executivo, e por chacinas de oponentes, como o Massacre do Teatro, em 28 de setembro, além da constante perseguição às chamadas classes perigosas. Foi esta força que deu origem à Polícia Militar, razão pela qual habitualmente se lhe atribui este nome retroativamente.
} 
concomitantes: emergem no mesmo tempo e espaço, o Rio de Janeiro do Período Regencial. Pacificada a Corte, ambos deixam de aí existir, podendo ser reativados em outras espacialidades. O problema do Haitianismo é que ele funciona; é eficiente, obtém sucesso. Pode emergir somente quando necessário, sob novas formas e pretextos, intercalado por lacunas e não emergências em sua genealogia.

Assim como nas narrativas sobre a MINUSTAH, há nas anedotas sobre Caxias, desde o início de sua carreira, uma ênfase em sua suposta humanidade pacificadora, capaz de fazer um "gesto de magnanimidade" contra um oponente desarmado, conforme insiste Holloway (1997, p. 100). Com efeito, há diversos feixes de relações envolvendo as narrativas elogiosas das pacificações de Caxias e do general Heleno, o primeiro Force Commander da MINUSTAH. Ambos são descritos como criadores de doutrinas inovadoras e bem-sucedidas, mesmo que a violência de suas incursões armadas contra o Outro, doméstico ou exterior, fosse o que deveria marcar suas trajetórias. O Haitianismo ajuda a suspeitar porque não foi como assassinos de Estado que eles entraram para a História, mas como heróis humanizados. Já no século XIX, esta prática discursiva podia variar, como visto nos capítulos 3 e 4, entre as agendas mais conservadoras (até homicidas) e as mais radicais de seu tempo, sempre sustentadas por apelos à humanidade e à razão.

Portanto, entender a própria MINUSTAH como Haitianismo é uma eficaz maneira de resistir ao poder dos discursos que seguem operando a conversão de chacinas policial-militares, perseguições e controle sociorracial da diferença como se fossem atos humanitários, necessários e legais. ${ }^{304}$ Por exemplo, a operação de guerra no Complexo do Alemão em 2010, quando foram empregados $60 \%$ de soldados que tinham passagem pelo Haiti ${ }^{305}$, que exterminou jovens diante de câmeras de televisão e mesmo assim foi declarada como "Força de Paz". ${ }^{306}$ Não

\footnotetext{
${ }^{304}$ Ver entrevista do general Fernando Sardenberg, comandante da "Força de Paz" no Complexo do Alemão em 2010, saudado pela imprensa como o responsável pela pacificação das favelas haitianas no primeiro ano da missão, quando Heleno era o comandante geral da missão. Disponível em (acesso em dezembro/2018):

https://oglobo.globo.com/rio/comandante-da-forca-de-paz-no-complexo-do-alemao-promete-rigorcontra-abusos-por-parte-de-2913179.

305 Ver reportagem em que o comandante militar da operação diz ser "triste ter que combater jovens que não se inseriram no contexto social”, disponível em (acesso em dezembro/2018): https://extra.globo.com/noticias/rio/general-da-brigada-paraquedista-que-ja-comandou-as-tropasbrasileiras-no-haiti-vai-comandar-forca-de-paz-no-alemao-184189.html.

306 Ver reportagem sobre o tema, que entrevista a ativistas de Direitos Humanos do Coletivo Papo Reto, do Complexo do Alemão, disponível em (acesso em dezembro/2018): https://www.vice.com/pt br/article/53mevd/a-pacificacao-do-complexo-do-alemao-deu-certo.
} 
eram para Caxias, nem são para Heleno. Mas é preciso muito esforço para combatêlos, dado seu sucesso biopolítico e a legião de seguidores que lhes confere status privilegiado, autoridade e salvo-conduto discursivo até hoje. ${ }^{307}$

\section{Paz Híbrida ou Paz Haitianista?}

O único trabalho de fôlego que aborda criticamente a imagem heroica produzida sobre Caxias (e sobre o marechal Rondon) para fazer uma releitura das narrativas sobre a MINUSTAH é justamente aquele que percebe como tais acontecimentos discursivos são cruciais para a estabilização de uma "identidade conciliadora, mediadora, integracionista e pacifista que, por meio de determinadas práticas e discursos de 'pacificação', busca-se projetar para o Brasil, e para o soldado brasileiro" (GOMES, 2014, p. 177). A tese de Maíra Gomes (2014), mencionada no capítulo 2, captura com precisão este aspecto da operação políticodiscursiva da qual o Haitianismo faz parte, ainda que não aborde o conceito diretamente.

O foco de seu trabalho está nos discursos que facilitaram a decisão brasileira de tomar parte na MINUSTAH. Logo, seu olhar é voltado, sobretudo, aos primeiros anos da missão. Diferencia-se, assim, da presente investigação, que é voltada para o momento final da intervenção, de seu término e das consequências de enunciados acerca do sucesso obtido pelo Brasil no Haiti. Há também uma diferença entre os objetivos de ambos os trabalhos: enquanto Gomes (2014) visa desconstruir noções positivistas sobre Política Externa que a entendem como projeções de interesses e/ou identidades nacionais previamente dadas; a presente investigação está mais interessada em abordar o exercício do poder envolvido em tais operações. Aqui, a interrogação é sobre tecnologias de poder.

A questão de todas estas genealogias é: o que é o poder, ou melhor (...) quais são, em seus mecanismos, em seus efeitos, em suas relações, os diversos dispositivos

\footnotetext{
307 Cumpre notar também a operação discursiva que transforma fraudes eleitorais massivas em supostos casos de criatividade que ajudariam a fomentar a democracia haitiana, como no caso do emprego da chamada Cláusula Belga, que garantiu a eleição (ou melhor, a posse sumária) de René Preval sem a realização de segundo turno. A celebração discursiva, como amostra de "inventivenes" e "creative manouvre" (MORENO et al. 2012, p. 385-386), daquilo que foi, na realidade, uma fraude eleitoral em larga escala, realizada em 2006 pelos interventores, é denunciada por Seitenfus (2016), dentre outros. Importa notar, como visto no capítulo 4, que os rumores de Haitianismo surgiam com muita freqüência justamente nos períodos eleitorais e não eram poucas as acusações de fraude e política de medo em que esta prática discursiva também estava envolvida durante o período de eleições. Em ambas irrupções, evitar o caos das revoltas negras era a maneira de explicar manobras de escolha do candidato preferido pelo status quo.
} 
de poder que se exercem a níveis diferentes da sociedade, em domínios e com extensões tão variados? (FOUCAULT, 1979, p. 174)

Daí o foco no Haitianismo, capaz de desnudar a "irrupção, força, dimensão e absurdo" (1979, p. 174) da colonialidade do poder biopolítico reativado pelas práticas discursivas que se esforçam para construir um regime de verdade sobre o sucesso da MINUSTAH. É por isto - pela ênfase na produtividade do poder - que foi preciso recorrer ao estudo do Haitianismo, pois é ele que revela um dispositivo central das técnicas de poder empregadas na MINUSTAH e seus bumerangues domésticos acima discutidos: o hibridismo. Incontornável diante do estudo da primeira irrupção de Haitianismo, vista nos capítulos 3 e 4, estes hibridismos entre $E u$ e Outro, interno e externo, brancos e negros, afeição e medo, repetição e originalidade, cuidado e controle, caos e ordem, civilizados e bárbaros, presença e ausência; enfim, estas ambivalências entre identidades e alteridades são técnicas que dotam o regime discursivo das pacificações contemporâneas com uma espécie de sobrepoder que assegura sua maior eficácia em situações que reclamam a produção de Estados pós-coloniais.

É justamente o hibridismo - apontado pelos próprios enunciadores que festejam o modelo brasileiro exibido na MINUSTAH - que está no cerne da produção deste "outro similar" que Gomes (2014, p. 211) acertadamente identifica como necessitado de uma assimilação complexa. "Não sendo o "outro" construído como uma alteridade radical” (2014, p. 173), ele requisita tecnologias de normalização que somente dispositivos de poder igualmente híbridos poderão assegurar. Mediante a genealogia do Haitianismo inverte-se a ordem dos discursos e pode-se perceber que primeiro foi preciso realizar as práticas de subjetivação dos negros como amigáveis $e$ ameaçadores para, em seguida, produzir o regime de verdade no qual são apresentados como válidos os enunciados sobre um jeito brasileiro capaz de compreendê-los e dominá-los com maior grau de sucesso.

Assim, mesmo que discuta criticamente a imagem de herói construída sobre Caxias para repensar o engajamento do Brasil na MINUSTAH, Gomes (2014) evita dar o passo seguinte no sentido de atacar frontalmente a "prática heroica" (ASHLEY, 1988, p. 230) envolvida na problemática do Haitianismo, ou seja, aquela que consiste na produção de sujeitos e objetos cuja relação de poder ativase justamente nas práticas discursivas destinadas a reafirmar o hibridismo como valor positivo. Gomes (2014) não enfatiza a centralidade do hibridismo para o 
regime de verdade envolto no modelo brasileiro de pacificação, que não apenas estabiliza um Self particular, mas que só é possível (e bem-sucedido) porque faz parte de uma prática de hibridização sociorracial no exercício do biopoder pós-colonial. Se é pertinente conceber a pacificação como prática da política externa/interna de um país como o Brasil, também é importante notar que o fundamento desse emergente regime de humanitarismo pós-colonial, que engloba tal política, é o complexo hibridismo de seus sujeitos e objetos de poder.

Esta prática heroica possui uma genealogia e um nome adequado: Haitianismo. A tese de Gomes (2014) aponta para uma questão relevante, mas é possível que lhe escape um ponto adicional, crucial para a presente investigação: que os pacificadores qua "conciliadores", de ontem e hoje somente podem ser construídos assim mediante a afirmação de seu hibridismo constitutivo, seja em termos raciais, bélico-táticos, sociais, políticos ou (inter)nacionais. Naturalmente, este não era o propósito de Gomes (2014), que elegeu outros objetivos para seu trabalho. O que ora se aponta é uma possibilidade de desdobramento do seu argumento em uma direção possível, dentre outras avenidas de interrogação fecundas abertas por sua tese. Por exemplo, uma hipótese que surge a partir da investigação da MINUSTAH como Haitianismo é que o hibridismo pode ser uma espécie de elo perdido entre o Self e o "outro", que sua análise percebe como partícipes de um encontro que "tende a se articular por meio de discursos e práticas de conciliação, mediação, integração e reconstrução" (2014, p. 173).

Em outras palavras, é o que articula a noção - de outra forma paradoxal de um Outro similar. Mais ainda, sob o prisma do Haitianismo, pode-se expandir o argumento ao ver que a contingência é, de fato, domesticada ao ser "trazida para dentro" do estado" e também "controlada"; mas que, ao mesmo tempo, a alteridade também é estrangeirizada e jogada para fora da comunidade política como visto no hábito de classificar o inimigo político como Haitiano, no século XIX, abrindo espaço para a negação de cidadania de quem fosse assim concebido, uma vez que tais direitos (às vezes suspensos, decerto), por definição, não aplicam-se a estrangeiros. O tropo do domesticar para controlar faz parte da mesma genealogia do estrangeirizar para exterminar. São mais poderosos porque caminham juntos.

É uma forma de encarar os clamores do ex-comandante da MINUSTAH, general Heleno, ao defender o abate e execução sumária de suspeitos nas favelas do Rio de Janeiro: estrangeirizando a diferença, pode-se abatê-los como animais 
selvagens, como se fossem os haitianos das "gangues" de Porto-Príncipe exterminados em nome da paz. Há um hibridismo poderoso - fatal - nas ambivalências entre militarização humana e militarização desumana, que a genealogia do Haitianismo é capaz de ressaltar, não sendo apenas uma identidade conciliadora, mediadora, pacifista ou integracionista aquela que é produzida em tais discursos. Muitas vezes, esta serve para viabilizar uma outra afirmação, que não jaz escondida ou disfarçada, mas verbalizada a seu lado: a da necessidade do extermínio, da chacina, da exclusão e da guerra declarada ao Outro. ${ }^{308}$

O hibridismo também opera na identificação dos próprios armamentos, ora explicitando sua letalidade enquanto objetivo declarado, ora avançando uma proposta humanitária. Assim é que, no Rio de Janeiro, os mesmos veículos blindados que recebiam a alcunha de "Caveirão" agora são chamados de "Branca de Neve" pelos moradores que são alvos de seu belicismo cotidiano, ao notarem a mudança de cor proveniente da inspiração estética nos tanques da ONU em operações de paz. Mas que não se engane: o inverso também ocorre, conforme demonstrado pelos veículos doados pela MINUSTAH às forças de segurança fluminenses, que foram pintados com a caveira-símbolo do Batalhão de Operações Especiais antes de serem utilizados domesticamente. ${ }^{309} \mathrm{O}$ Haitianismo não é unidirecional. Seu poder circula mediante emaranhados que não servem apenas para suavizar discursivamente a determinadas políticas mortíferas, mas, principalmente, para manter um fluxo constante entre tecnologias variadas, que podem valer-se de enunciados até mesmo opostos. Como relembra Castro-Gómez (2007), não "podemos considerar o poder como algo maciço e homogêneo, que opera em uma só direção, mas como algo que circula em muitas direções e 'funciona em cadeias'. Em uma palavra: o poder é multidirecional e funciona sempre em rede" (2007, p. 161-162).

\footnotetext{
308 Sobre as ações de enfretamentos às gangues de Porto-Príncipe, ver as repetidas narrativas produzidas por militares brasileiros, que enfatizam o "intenso uso da força" (BRAGA, 2017, p. 42), os "conflitos intensos e constantes" com "gangues que estavam fortemente armadas" (MENDONÇA, 2017, p. 59-61) e "gangues criminais e paramilitares" (VIEIRA NETO, 2017, p. 19) derrotadas pelas Forças Armadas brasileiras. Um deles admite, sem reservas, que era impossível distinguir, dentre os "grupos hostis", aqueles que possuíam "propósitos exclusivamente criminais" daqueles com "propósitos políticos" (BRAGA, 2017, p. 41). Ambos teriam sido erradicados pela MINUSTAH.

${ }^{309}$ Ver reportagem da Folha de S. Paulo, disponível em (acesso novembro 2018): https://www1.folha.uol.com.br/cotidiano/2018/03/intervencao-cede-tanques-do-haiti-ao-bopecom-aparato-menos-letal.shtml.
} 
Tratar as práticas discursivas da MINUSTAH como Haitianismo também ajuda a evitar narrativas excessivamente internalistas ou brasilianistas, que podem produzir o efeito contrário ao desejado e terminar contribuindo para a fixação de uma determinada identidade brasileira. Pois a genealogia do Haitianismo permite considerar que as pacificações que se apresentem, de uma só vez, como violentas $e$ conciliadoras possam ser atributos de toda comunidade política que se construa por meio de hibridismos, ambivalências e miscigenações, como faz o Brasil - que não é único nesta prática discursiva (CANCLINI, 2015). Neste sentido, tratar-se-ia não somente de uma faceta da Política Externa Brasileira, em particular, mas de uma possibilidade biopolítica de Estados pós-coloniais em geral, nos quais o terceiro espaço identitário descrito por Homi Bhabha - grande teórico do hibridismo produz efeitos de poder recorrentes. É o caso de se investigar.

Como visto no capítulo 2, na teoria de Relações Internacionais, os debates sobre a chamada Paz Híbrida nas intervenções humanitárias ganharam considerável espaço na última década. Trabalhos de peso como os de Oliver Richmond e Audra Mitchell (2012) e Roger Mac Ginty (2011) propuseram uma nova abordagem para se compreender os sucesso e fracassos das missões ocorridas até então. Sua aposta era que se pudesse aprimorar as intervenções a partir da mitigação dos piores efeitos (coloniais, eurocêntricos) da paz liberal mediante uma atenção maior às sociedades-alvo. Esta virada local resultaria em um hibridismo entre as práticas interventoras e as experiências e saberes locais, o que poderia ensejar até mesmo formas de interações pós-liberais (FACCHINI; TOLEDO, 2017).

No entanto, após alguns anos de rápida disseminação, os próprios expoentes da Paz Híbrida passaram a questionar a qualidade teórica e empírica das experiências feitas a partir daquilo que também foi chamado de virada híbrida. Em The Fallacy of constructing hybrid political orders, Richmond e Mac Ginty (2015) unem-se para criticar severamente as tentativas de instrumentalização do hibridismo pelas organizações internacionais e Estados interventores. $\mathrm{Na}$ contramão da euforia desatada pelas proposições do hibridismo como panaceia para o melhoramento das intervenções, eles afirmam:

$[\mathrm{M}] \mathrm{uch}$ of this renaissance of interest in hybridity is shallow in nature and is driven by a mix of a misunderstanding of the complexities of hybridized processes, and a growing realization, among interveners, of their limited powers. Norm diffusion, 
normative or soft power, or local onwnership, localization, to mention just a few recent buzzwords, have evaded ethical issues and sometimes provoked resistance (...) Fundamentally, our argument is sceptical of the possibility of instrumentalizing hybridity (...) Hybridity is not a condition that can be crafted in a laboratory and rolled out in neat factory packaging as part of a peacebuilding, stabilization or development programme. Attempts to instrumentalize hybridity seem to have a scant understanding of local agency and the ability of the interaction between local and international actors to produce unexpected outcomes. It also evades ethical questions relating to social and distributive justice, which as a result cannot be settled. (...) The article asserts that the conscious construction of hybrid political orders is often a fraught and wasted exercise, while contextually forming political hybrids may have advantages in terms of securing local legitimacy. (MAC GINTY; RICHMOND, 2015, p. 2)

Deste modo, ao passo que os próprios proponentes mais famosos do conceito estejam a cada dia mais céticos quanto a sua utilização prática, torna-se cada vez mais difícil seguir postulando o hibridismo em si como benigno, positivo ou como solução para uma nova geração de intervenções, sejam elas comandadas pelo Brasil ou por outras comunidades políticas autoidentificadas com formações raciais miscigenadas. Conforme notado por um comentador não totalmente contrário à agenda da Paz Híbrida:

The insertion of the idea of hybrid peacebuilding, which combining the liberal and the illiberal norms, has indeed created ambivalence. On the one hand, hybrid peace approach attempts to reduce the domination of liberal system and norms. On the other hand, the combination of the liberal and illiberal, that is not intended to retreat the liberal norms from hybrid peacebuilding, is basically a new way to expand the liberalism itself in peacebuilding particularly to the non-Wester society. (ANAM, 2015, p. 46)

Ainda que os autores canônicos não deem o último passo no sentido de abandonar o conceito definitivamente, capitulando frente a sua funcionalidade aos exercícios do poder, já desponta no horizonte uma crescente percepção crítica - da qual esta investigação é parte - que percebe o perigo desta "falácia" e ousa propor não mais uma rodada de melhoramentos nas intervenções da paz liberal, da Paz Híbrida ou da paz pós-colonial, mas o fim desta prática ingerencista, principalmente quando fundamentada na ação de meios militares em posição de destaque. Se o hibridismo não foi capaz de consertar os defeitos do humanitarismo interventor, tampouco adianta tentar corrigir os erros do hibridismo para manter o seu uso, mesmo que aperfeiçoado, daqui por diante.

O risco de se sair da paz liberal, via a tentativa de erigir uma Paz Híbrida, em direção a uma paz pós-colonial igualmente opressiva (ou ainda mais eficiente 
em seu controle das populações-alvo) é patente. O exemplo da MINUSTAH o ilustra paradigmaticamente. Clamores por mais interação com a população local (BLANCO; GUERRA, 2017) ou apologias da maior capacidade de negociação e criatividade devido a um passado colonial compartilhado (CLAUHS, 2013; MORENO et al., 2012) tampouco solucionaram esta delicada questão. Ao final, o modelo brasileiro (KENKEL, 2011) ou a propalada "pax brasiliensis" (NASSER, 2012, p. 213) acabam sendo melhor encarados, por seus efeitos de poder, como Paz

\section{Haitianista.}

O estudo do Haitianismo, como tecnologia de poder que combina violência estatal com empatia individual - centrado na gestão, melhoramento e controle biopolítico de populações racialmente caracterizadas - mostra que apelos, ainda que teoricamente sofisticados, à continuidade do intervencionismo militar engendram, pois, um risco tremendo. Quando confrontados com genealogias de formações discursivas que apregoam as benesses de uma "colonização híbrida" (SANTOS, 2014; FREYRE, 2004, p. 136), seus efeitos de poder emergem com mais nitidez. Em vez de significar a emancipação e progressismo desejados por Mac Ginty e Richmond (2015), tais modelos de Paz Híbrida, mesmo que aperfeiçoados, tendem a reproduzir uma colonialidade inescapável, conforme notado por Sabaratnam (2013).

Na melhor das hipóteses, esta Paz Haitianista oferece maior grau de sucesso para o mesmo projeto da modernidade/colonialidade, que sempre assumiu diferentes formas e teve capacidade para se adaptar, hibridizar e manter-se em marcha (CANCLINI, 2015). É chegada a hora de rejeitar com mais assertividade a narrativa que insiste que somos melhores na tarefa de pacificar esses Outros similares (negros, indígenas, "locais") porque também somos pós-coloniais. $\mathrm{Na}$ realidade, somos piores justamente por isso. O Haitianismo nos obriga a lembrar do tipo de sucesso outrora obtido por um regime escravista aperfeiçoado por intelectuais, políticos e comandantes militares brasileiros: ser o mais resiliente e duradouro de todo o hemisfério ocidental. Após um turbulento Período Regencial, lograram que não houvesse uma revolução como a haitiana no Estado que estava sob sua administração.

\section{Considerações finais}

Este capítulo mostrou como as estratégias analíticas inspiradas na obra de Michel Foucault podem ser frutíferas para uma análise crítica dos objetos de 
atenção desta investigação. Ao tratar as narrativas que produzem o Haitianismo e a MINUSTAH como acontecimentos discursivos, pôde-se fazer uma arqueologia de seus saberes mediante as regras de formação de seus sistemas de dispersão de objetos, conceitos, modalidades enunciativas e escolhas temáticas. Em seguida, foi possível perceber que, apesar das diferenças de contexto, havia uma mesma prática discursiva em ambas as irrupções, sendo adequado tratá-las como emergências distintas dentro de uma mesma genealogia. Este movimento não se configurou como uma inovação teórico-metodológica, mas uma forma explicitamente tática de tentar resistir aos efeitos de poder próprios a este regime discursivo. Esboçou-se, então, uma abordagem que mostra o que se pode ganhar, em termos teóricos e políticos, ao conceber a MINUSTAH como Haitianismo neste regime que também pode-se chamar de humanitarismo pós-colonial. Por fim, aventou-se a possibilidade de que a Paz Híbrida desemboque numa Paz Haitianista, tão, ou mais, problemática quanto a paz liberal.

Quando as populações-alvo (é um disparate chamá-las de anfitriãs) ${ }^{310}$ são consultadas e o anonimato garantido, tendem a produzir enunciados contrários que desafiam o discurso dos pacificadores humanitários. Mesmo diante de todas as assimetrias de poder que praticamente interditam uma autorrepresentação autêntica das vozes subalternizadas, elas insistem em provocar o regime discursivo vigente, sendo, por isto, imperioso silenciá-las a todo instante, excluí-las do campo de acontecimentos discursivos considerados válidos. Não obstante as reticências de Spivak (1988) sobre as possibilidades do subalterno falar, novas contribuições, como o trabalho de Opondo e Shapiro (2018), insistem que sim. ${ }^{311}$ Tais autores não são os únicos com tal convicção.

\footnotetext{
310 Há uma política envolvida neste léxico: enquanto os defensores da paz liberal e críticos moderados geralmente usam a terminologia de "anfitriãs", as análises críticas mais consistentes, como Sabaratam (2013), não duvidam em revelar tais populações como elas são: "alvos" das intervenções. Sobre a condição de alvo de intervenções multilaterais, Marc Trachtenberg (1993) destaca: "To be a target of intervention - indeed, even of humanitárian intervention - was to be stigmatized as of inferior status (TRACHTENBERG, 1993 citado por VITALIS, 2000, p. 339).

311 As entrevistas feitas pelo autor com movimentos sociais no Haiti também apresentam um discurso contrário ao dos interventores. Embora não caibam no escopo desta tese, merecem ser lembradas e serão utilizadas em trabalhos posteriores. Vale notar que o autor fez parte, por oito anos, de iniciativas que tentaram amplificar tais vozes. Diante do limitado alcance, tentou-se nesta tese percorrer um caminho distinto, interrogando o próprio sucesso propalado pelos enunciadores do modelo brasileiro ilustrado pela MINUSTAH, já que este discurso firmara-se como o único permitido em diversos espaços de produção e difusão de saberes sobre o tema. Um exemplo de tal interdição deu-se quando o autor solicitou que fosse repassado um convite para um debate sobre a MINUSTAH e as UPPs (com intelectuais haitianos e ativistas de favelas cariocas) pela lista de $e$ mails do instituto onde lecionava à época, tendo recebido resposta negativa da coordenação do curso.
} 
O que é demonstrável por estudos que vocalizam dissidências, resistências e mesmo oposições abertas à militarização pós-colonial, como exemplificado pelos trabalhos de Marielle Franco (2018) sobre as UPPs, de Gizele Martins e Jessica Santos (2018) sobre a Intervenção Militar Federal no Rio de Janeiro ou de Eliana Silva (2017) sobre a percepção dos moradores do Complexo da Maré em relação às Forças Armadas em suas comunidades durante os Mega Eventos esportivos. São falantes também nos trabalhos de Franck Seguy $(2014 ; 2015)$ sobre a Internacional Comunitária em seu país, na obra de Gina Ulysse (2015) sobre as razões da necessidade de novas narrativas sobre seu país-natal ou nos inúmeros comunicados da Plataforma Haitiana de Advocacia por um Desenvolvimento Alternativo (PAPDA), ${ }^{312}$ além do trabalho de fôlego organizado por Adriana Santiago intitulado Haiti por si: a reconquista da independência roubada (2007). Vozes subalternas falam, ouvidos colonizados não escutam. Desconsideram-nas por destoarem do regime de verdade em vigor.

Excluídas sistematicamente, sobram sempre os mesmos enunciados, conceitos, objetos e escolhas temáticas que reafirmam o poder dos agentes humanitários, incluindo os militarizados, com a sua narrativa sobre o sucesso. Esta prática é sustentada por uma ampla aliança que inclui agentes governamentais, agências multilaterais, grande imprensa, institutos universitários e organizações governamentais. ${ }^{313} \mathrm{O}$ conceito de "portas giratórias" (revolving doors) ajuda a captar parte do que está em jogo nestas relações. Não raro as imbricações são tão intensas que nem seria tão rigoroso encará-las como alianças, noção que retém uma autonomia ontológica para cada um dos entes envolvidos.

O mesmo que circulava convites frequentes para eventos conjuntos com militares nos quais defendia-se abertamente a intervenção, sem vozes dissidentes.

312 A titulo de exemplificação, conferir uma das cartas enviadas pela PAPDA ao comando da MINUSTAH e ao Conselho de Segurança da ONU em (acesso em novembro/2018): http://www.papda.org/article.php3?id_article=1244.

${ }^{313}$ Os inúmeros eventos públicos celebrados palas Forças Armadas brasileiras sobre a MINUSTAH atestam a composição da aliança. Por exemplo, no "Seminário Internacional: 13 anos do Brasil na MINUSTAH: lições aprendidas e novas perspectivas", realizado em novembro de 2017 pela Escola de Operações de Paz de Caráter Naval no Centro de Instrução Almirante Sylvio de Camargo, no Rio de Janeiro. Na ocasião, fora os discursos praticamente idênticos (uma única exceção é digna de nota), houve até demonstrações de "ações no mar" e "ações em terra", além de zombarias ao suposto hábito das haitianas de não usar roupas íntimas ("calcinhas"), dentre outras amostras de sua alegada incivilidade, enunciado por uma das personalidades oradoras. A mesma que também afirmou ter aplicado vacinas nas nádegas de haitianas sem, no entanto, ter qualificação profissional ou autorização das Nações Unidas ou do Governo Haitiano para tais atos. Junto dos atores habituais, a Academia Brasileira de Letras e o Grupo Globo de comunicação também estiveram presentes, com representantes na condição de palestrantes. 
Pois diante da união íntima vista nos últimos anos, talvez seja preciso repensar a individualidade daqueles que fizeram do Haiti uma carreira, uma vez que parecem tomar parte da mesma empresa. Pode-se, novamente, sugerir o paralelo com Edward Said (2003), que também afirmava ser o Oriente "uma carreira” (2003, p. 5). De fato, ao se trocar Orientalismo por Haitianismo, temos uma descrição parcial do que está em jogo nas relações entre poder e saber estudadas nesta tese:

Orientalism [Haitianism] can be discussed and analyzed as the corporate institution for dealing with the Orient [Haiti] - dealing with it by making statements about it, authorizing views of it, describing it, by teaching it, settling it, ruling over it: in short, Orientalism [Haitianism] as a Western [Brazilian] style for dominating, restructuring and having authority over the Orient [Haiti]. (SAID, 2003, p. 3) $)^{314}$

O nome, ou razão social, desta instituição corporativa, como sugerido por Ulysse (2015), deveria ser (naturalmente, em inglês) white-savior-industrial complex. Três exemplos atuais o mostram.

Primeiro, a ONG Viva Rio afirma em sua página virtual que foi convidada pela MINUSTAH para estabelecer-se no Haiti, onde chegou a ter um escritório com mais de 113 funcionários. Recebeu financiamento da força de ocupação para realizar atividades esportivas e culturais em favelas da capital haitiana, como aulas de capoeira e celebrações carnavalescas (ABDENUR; CALL, 2017, p. 29). Fundada em 1993 com o intuito de conter a reação popular contra duas chacinas promovidas pelo grupo de extermínio Cavalos Corrredores, formado por policiais militares do Rio de Janeiro, esta ONG é geralmente destacada nos discursos que apontam o jeito brasileiro de pacificação humanitária como sendo um diferencial do país (ABDENUR; CALL, 2017, p. 14; HIRST, 2012, p. 25; KALIL; NAPOLEÃO, 2015, p. 105; KENKEL, 2011, p. 29). Sempre defensora da militarização (como o fazem ainda em 2018 diante da intervenção no Rio de

\footnotetext{
${ }^{314}$ Isto não significa que o Haitianismo seja exatamente como o Orientalismo, mas que pode ser uma forma dele. Pois o Haitianismo é uma formação discursiva que emerge no próprio mundo póscolonial, de forma a disciplinar-se e autogovernar-se. O Orientalismo é Norte-Sul ao passo que o Haitianismo é Sul-Sul. Ao mesmo tempo, o Haitianismo reivindica uma singularidade dentro do regime humanitário, dado este lugar de fala, esta origem subalterna que o ajuda na busca por purificar-se do ethos civilizador branco-ocidental racializado binariamente. Neste sentido, o Haitianismo resgata o civilizador branco de si mesmo, a razão humanitária de sua mancha civilizatória, tão difícil de apagar, até mesmo na literatura crítica à paz liberal. Assim como Toussaint L'Ouverture quer resgatar as luzes da Revolução Francesa ao emancipar os escravizados no Haiti, os missionários brasileiros querem resgatar o humanitarismo mediante a sua haitianização, ou seja, implementando o humanitarismo miscigenado e pós-colonial, que pode se apresentar como mais progressista dentre todos os intervencionismos disponíveis.
} 
Janeiro) $)^{315}$, a Viva Rio busca representar a face humana destas políticas, a fim de garantir o tão importante hibridismo operacional e discursivo, que une o uso da força ao assistencialismo.

Após a internacionalização promovida pela passagem pelo Haiti, esta ONG hoje adentrou as estruturas do próprio Estado brasileiro, sendo administradora de 75 unidades de saúde no Rio de Janeiro, na sua maioria em regiões periféricas e de maioria negra. A baixa qualidade do atendimento, o não pagamento dos médicos e a suspensão dos serviços levaram à investigações e abertura de processos por corrupção pelo Ministério Público Estadual. ${ }^{316}$ No entanto, suas atividades não param de crescer e até mesmo um fundo de investimentos no mercado financeiro foi aberto pela ONG, que se tornou uma "empresa social". Um sucesso, ao menos do ponto de vista dos negócios, que envolvem parceiros estatais, privados e do chamado terceiro setor. ${ }^{317} \mathrm{~A}$ Viva Rio criou até mesmo seu próprio time de futebol profissional, que compete nas categorias sub-17 e sub-20, no Rio de Janeiro, com jovens que a entidade importa do Haiti mediante seu projeto "Pérolas Negras", cujo nome dispensa comentários, além dos óbvios: a racialização vem acompanhada de uma alusão ao apelido - "Pérola das Antilhas" - pelo qual a colônia francesa era conhecida na época colonial, quando era o território que mais produzia riquezas (para sua metrópole) em todo o mundo, mediante trabalho escravo. A passagem pelo Haiti fez desta ONG uma firma humanitária multinacional. ${ }^{318}$

315 Ver o posicionamento oficial da ONG sobre a Intervenção Militar em (acesso em Novembro/2018): http://www.vivario.org.br/opinioes-do-viva-rio-diante-da-intervencao-federal-na-segurancapublica/.

316 Ver reportagem do portal G1 em (acesso em Novembro/2018): https://g1.globo.com/rj/rio-de-janeiro/noticia/2018/10/29/prefeitura-encerra-contrato-com-os-queadministrava-hospital-ronaldo-gazzola-no-rio.ghtml. Ver também: http://g1.globo.com/rio-dejaneiro/noticia/2016/01/nova-clinica-da-familia-sera-gerida-por-os-investigada-pelo-mp-rj.html.

317 Ver mais informações em (acesso em Novembro/2018): https://projetodraft.com/o-viva-rioinova-ha-20-anos-quando-juntou-intelectuais-e-liderancas-comunitarias-contra-a-violencia-no-rio/. ${ }^{318}$ Para mais sobre o projeto e as imbricações estatais da ONG, ver a explicação de Rubem César Fernandes, seu fundador: "Por conta deles, o Viva Rio tornou-se um clube profissional filiado à Federação de Futebol do Estado do Rio de Janeiro, que compete nas categorias sênior, sub 20 e sub 17. Deste modo, guardadas as devidas proporções, seguimos a "diplomacia do futebol" que foi inaugurada no Haiti pela Seleção Brasileira em 2004. Com ela, formamos um elo permanente de relacionamento produtivo entre o Haiti e o Brasil. O trabalho com os Pérolas Negras conta com o apoio da seção de Cooperação Esportiva do Itamaraty, assim como, e sobretudo, com a Embaixada e o Consulado do Brasil no Haiti. Aliás, sem o apoio dos nossos diplomatas o trabalho do Viva Rio no exterior seria impossível. Deixo minha homenagem e meu agradecimento ao serviço consular e aos embaixadores Paulo Cordeiro de Andrade Pinto, Igor Kipman, José Luiz machado e Costa e Fernando de Mello Vidal que nos apoiaram para além dos limites protocolares, em cada momento desta pequena história. Cada história é única, seja ela pequena ou grande. Histórias a rigor não se repetem e não são comparáveis. Elas precisam ser contadas. A interpretação histórica aproxima-se 
Segundo exemplo. A ONG Instituto Igarapé, criada por ex-integrantes do Viva Rio, se notabilizou por seu trabalho em prol de políticas de policiamento inteligente (smart policing) e trabalhos conjuntos com a MINUSTAH e a Polícia Militar do Rio de Janeiro, que figuram em sua lista de apoiadores. Conforme sua autodescrição, trata-se de um “think and do tank”, ou seja, não apenas uma máquina formuladora de políticas, mas implementadora das mesmas também. Dentre diversos estudos promovidos pelo instituto que celebram as políticas de humanitarismo militarizado brasileiras, destaca-se uma publicação recente que faz uma espécie de balanço da MINUSTAH: um material produzido em conjunto com o CCOPAB, no qual acadêmicos, militares, diplomatas e funcionários da ONG (re)produzem o regime de verdade sobre o Brasil no Haiti. Além da organização ser assinada por uma funcionária da ONG e um militar que comanda este Centro, o financiamento também é conjunto e há artigos em que os militares compartilham a autoria com os acadêmicos e funcionários do instituto, demonstrando o nível de envolvimento entre ambos, que também pode ser atestado pela presença de ambas logomarcas, uma ao lado da outra, no cabeçalho do material, dentre outras imbricações. A maior delas, naturalmente, é a total falta de discursos que destoem minimamente da narrativa dominante. Todas as vozes compiladas falam em uníssono. A palavra "sucesso" é utilizada 29 vezes pelos 13 artigos da brochura para referir-se ao êxito da missão. ${ }^{319}$

Terceiro. Ainda na esteira das comemorações sobre o sucesso da MINUSTAH, as Nações Unidas criaram uma campanha intitulada "Serviço e Sacrifício". O evento de lançamento no Brasil deu-se no Rio de Janeiro, em junho de 2018, reunindo atores envolvidos nas intervenções, a fim de homenageá-los pelo seu trabalho. Além do Instituto Igarapé, estiveram presentes jornalistas, autoridades

\footnotetext{
da literatura ficcional, onde fatos, percepções e versões interpenetram-se de modo fascinante e irremediável. No entanto, a gente aprende com elas, ganha experiência. Acredito que o Haiti capacitou o Viva Rio para engajar-se em outras missões de paz. Ensinou-nos também a trabalhar em territórios estrangeiros, em colaboração estreita com as Forças Armadas brasileiras. Estamos aliás em Goma, na República Democrática do Congo, com o "Gingando pela Paz" e contamos ali com a participação de capoeiristas que formamos em São Gonçalo, no Estado do Rio, e em Bel Air, no Haiti. Os pés no chão, como na infantaria, e a cabeça além-fronteiras" (FERNANDES, 2017, p. 117).

${ }^{319}$ HAMANN, E.; TEIXEIRA, C. (Orgs.). Participação do Brasil na MINUSTAH: percepções, lições e práticas relevantes para futuras missões (2004-2017). Edição especial - coletânea de artigos. Rio de Janeiro: Instituto Igarapé/CCOPAB, 2017.
} 
militares, diplomáticas e representantes da academia. ${ }^{320} \mathrm{O}$ tema do evento dizia respeito ao "sacrifício" - mas não dos haitianos, e sim dos próprios interventores! Invertendo os lugares de sujeitos e objetos, celebrou-se a caridade, filantropia e humanidade daqueles que se doaram em prol de ajudar a reconstruir o Outro (que não foi convidado para a festividade, por sinal). Houve entrega de medalhas e exibição de vídeos “de militares brasileiros no terreno". ${ }^{321}$ Apesar da multiplicidade de atores, o resultado reiterou a unicidade discursiva autoelogiosa daquilo que Duffield (2007) chamou, com certa dose de exagero, de "império humanitário", com seus "novos arranjos institucionais e divisões do trabalho ligando governos doadores, agências da ONU, militares e ONGs" (2007, p. 8).

Assim como no momento da irrupção do Haitianismo no século XIX, a confluência dos distintos atores envolvidos em sua formulação atual chama a atenção. Uma das anedotas sobre a cunhagem do termo Haitianismo, como visto no capítulo 4, atribui sua autoria a um membro da Sociedade Defensora da Independência Nacional que, durante uma de suas reuniões no Rio de Janeiro, solicitou que fosse incluído este conceito em uma circular distribuída à outras províncias. Há sugestões de que este membro seria o próprio Evaristo da Veiga, cuja identidade é híbrida entre membro deste tipo de associativismo (precursor das ONGs de hoje em dia), parlamentar, empresário, jornalista e cronista político. O tipo de persona produtora do saber que acompanha este exercício do poder une múltiplas identidades: institucionais, pessoais, corporativas e políticas. E assim como antes, a ativação do Haitianismo permite que agendas distintas confluam para uma mesma prática de prevenção da agência subalterna que possa ameaçar o status quo em diferentes dimensões.

Do ponto de vista de quem se propõe - ou precisa - resistir ao poder do Haitianismo, ontem e hoje, o problema em tal imbricação reside na maior qualidade das estratégias e táticas desenvolvidas por estas alianças multifacetadas. Heathershaw (2008) chamou este processo de "cross-fertilisation" (2008, p. 15). Em outras palavras, o refinamento alcançado pela conjunção de várias vozes, cada

\footnotetext{
${ }^{320}$ Além da ONG e da Pontifícia Universidade Católica do Rio de Janeiro, consta na lista de organizadores também o Centro Conjunto de Operações de Paz do Brasil "Sérgio Vieira de Mello" (CCOPAB), A Rede Brasileira de Pesquisa sobre Operações de Paz (Rebrapaz) e o Centro de Informações das Nações Unidas para o Brasil (Unic Rio).

${ }^{321}$ Para mais informações, ver a divulgação oficial do evento em (acesso em Novembro/2018): https://nacoesunidas.org/onu-e-parceiros-lancam-campanha-no-brasil-em-homenagem-forcas-paz/
} 
qual contribuindo com seu saber específico, permite que os discursos do humanitarismo pós-colonial adquiram um grau de sofisticação que, separadamente, não conseguiriam ter. $\mathrm{O}$ hibridismo da paz haitianista, portanto, não é apenas um adereço linguístico, mas está na própria ontologia do ser social destes enunciadores, que circulam entre vários espaços de produção de saberes.

Preocupa, sobretudo, a crescente mistura entre os locais de enunciação militares e civis, uma vez que os primeiros parecem estar se beneficiando das inovações teóricas dos últimos, como fica demonstrado pelo estudo de Zehfuss (2012) sobre o emprego de cientistas sociais pelo exército norte-americano ou pela utilização de arcabouços teóricos "pós-positivistas" (CLAUHS, 2013, p. 108) por uma nova geração da intelectualidade militar brasileira, a fim de aprimorar seus modelos de intervenção a partir da experiência desenvolvida com o engajamento teórico e bélico com a MINUSTAH. Conforme esta mesma autora alertara sobre a relação entre o construtivismo e o conceito de identidade na teoria de Relações Internacionais, que serviria a um propósito conservador e até mesmo militarista (ZEHFUSS, 2001), também há uma "ligação perigosa" (dangerous liason) entre teóricos pós-positivistas desta disciplina e as agendas promotoras do intervencionismo humanitário pós-colonial, principalmente no que diz respeito aos usos e abusos das noções de hibridismo, ambivalência e negociação. ${ }^{322}$

Para que seja viável, a resistência a este tipo de exercício do poder precisa lançar mão de ferramentas que cortem o conhecimento (re)ativado neste regime discursivo. A libertação dos saberes referentes ao Haitianismo é uma destas armas, mas não é a única, certamente. Junto de outras, têm a chance de retalhar as narrativas sobre sucesso e sacrifício (BORBA DE SÁ, 2018), que invertem algozes e vítimas, transformam fracassos em êxitos, mas que atualmente constituem a verdade sobre as missões civilizatórias militarizadas. Não apenas nas favelas do Rio de Janeiro ou do Haiti, mas em diversos espaços produzidos discursivamente como frágeis, caóticos ou desgovernados, alvos da "nova estratégia" da ação humanitária atual (NOGUEIRA, 2014, p. 1.446; CONSTANTINOU; OPONDO, 2016).

Sem isto, prevalecerá, novamente, o discurso que entende como sucesso a manutenção do próprio regime humanitário vigente. Mesmo que seja aprimorado,

${ }^{322}$ Las Relaciones Peligrosas também é o título do prefácio de Raoul Peck [2014] ao livro de Ricardo Seitenfus (2016) sobre a MINUSTAH. 
teórica e militarmente, por um renovado viés pós-colonial, a fim de garantir a perpetuação das práticas de biopoder e colonialidade de uma repaginada paz liberal - ou, quiçá, de algo ainda mais perverso e difícil de enfrentar. 


\section{CONCLUSÃO}

Esta investigação propôs uma reflexão sobre as relações entre construção de saberes e tecnologias de governo de populações racializadas como não brancas a partir da análise da formação discursiva do Haitianismo no Brasil. A tese central aqui defendida foi que as narrativas sobre um modelo brasileiro de realizar operações de paz, que teria na MINUSTAH sua expressão mais acabada, buscam apresentar como inovador um dispositivo que, na realidade, possui uma genealogia delineável, que remonta ao século XIX e aos embates próprios à produção de um Estado pós-colonial em meio a um regime escravista. São práticas discursivas que ativam uma forma de poder cuja eficácia se manifesta na durabilidade tanto da escravidão que tentava evitar destino semelhante ao da Revolução Haitiana, quanto na intervenção militar que se afirma mais capacitada para estabilizar o Haiti devido a pouca diferença racial e social entre ambas as nações.

Após introduzir o tema e a problemática tratadas pela tese, o capítulo 2 situou-a nos debates da teoria de Relações Internacionais acerca da paz liberal. Dentre as diferentes formas de esquematizar as discussões, escolheu-se adotar a nomenclatura de Roland Paris (2010) sobre as posturas hipercríticas, invertendo-lhe a conotação pejorativa em busca de uma forma de abordar o intervencionismo humanitário contemporâneo que fosse mais consistente do que as propostas que se limitam a mitigar seus piores efeitos.

No capítulo 3, discutiu-se a produção historiográfica sobre o Haitianismo, de modo a introduzir as ferramentas com as quais poder-se-ia realizar a análise crítica da MINUSTAH, destacando-se a ambivalência semântica do conceito. $\mathrm{O}$ capítulo 4 debruçou-se sobre documentos originais do século XIX, de modo a avançar na compreensão das múltiplas agendas e modalidades enunciativas a que o Haitianismo se prestava, não tanto como repercussão da Revolução Haitiana no Brasil, mas como uma maneira própria de fazer política no nascente Estado pós-colonial imperial. Tanto fontes secundárias quanto as primárias revelaram expressões de colonialidade e biopoder relacionadas aos usos do Haitianismo.

No capítulo 5, retornou-se para a MINUSTAH a partir da literatura que exalta a atuação brasileira nesta missão, assim como a análise de entrevistas feitas 
pelo autor em viagem de campo ao Haiti. Por fim, no capítulo 6, com ajuda das formulações de Michel Foucault sobre arqueologias do saber e genealogias do poder, sugeriu-se tratar definitivamente a MINUSTAH como Haitianismo, diante da constatação de que fazem parte de uma mesma formação discursiva cujas práticas de poder sobre o Outro apresentam-se como particularidades distintivas de espaços políticos pós-coloniais, como o Brasil.

Não se buscou, aqui, negar o sucesso destas práticas, mas interrogar os efeitos de poder que produzem e os mecanismos pelos quais conseguem obter êxito. Identificou-se, nesse sentido, a sofisticação de um dispositivo que funciona por meio de deslocamentos, inversões, lacunas e reativações de expedientes políticos complexos. Tais aparatos oscilam entre o emprego de violência abismal e explícita, por um lado, junto a técnicas de valorização da vida, dos direitos e da humanidade alheia, por outro. Ainda que jamais desprovidas de resistências tenazes, tais tecnologias apresentam-se como capazes de se reinventarem continuamente, já que estão abertas a negociações, ambivalências e criatividade frente às situações de questionamento do status quo. Mais especificamente, são destinadas à produção de subjetividades subalternas controladas por poderes disciplinares, assim como ao manejo de populações, classificadas como pobres e negras, via mecanismos de engenharia social que garantam seu governo.

Para que funcionem, estas operações requisitam, por seu turno, da postulação de um sujeito em posição de autoridade que seja híbrido o suficiente para estabelecer relações de afeto com indivíduos das "raças" e classes sociais sobre as quais o poder é exercido, sendo, ao mesmo tempo, seu protetor amigo e o temido senhor de seus destinos. Requerem também crescentes incrementos na soberania do Estado e das preocupações com a governamentalidade sobre segmentos populacionais que se pode fazer viver ou deixar morrer. Assim, diante de uma perspectiva genealógica que recupera os embates e debates nos quais surgiu um conceito como Haitianismo, foi possível retalhar o discurso hegemônico sobre a militarização supostamente mais humana, ou mesmo benigna, praticada pelas Forças Armadas brasileiras no Haiti. Justaposta aos mitos da colonização híbrida, da escravidão sem racismo e do colonizador benevolente, a narrativa simpática à suposta singularidade brasileira vista na MINUSTAH perde sua alegada originalidade, revelando-se parte de uma linhagem conhecida por sua capacidade 
de submeter os seres humanos às piores relações de poder que existem: a escravização sistemática e racializada; e o estado de exceção militar.

O estudo do Haitianismo como dispositivo de poder característico do mundo pós-colonial também pode abrir caminho para a investigação de um conjunto de problemas para além da MINUSTAH. Há, certamente, outras irrupções nesta genealogia que precisam ser abordadas em trabalhos posteriores. $\mathrm{O}$ século $\mathrm{XX}$ produziu emergências significativas desta prática, como indicado brevemente nesta tese ao registrarem-se as formulações de Oliveira Vianna $(1930 ; 1945)$ sobre a invasão norte-americana do Haiti, entre 1915 e 1934. Seria igualmente importante retomar o caso da intervenção militar de 1965 sobre a República Dominicana, quando tropas brasileiras se juntaram aos contingentes da Força Interamericana de Paz, majoritariamente composta pelos Estados Unidos da América, sob autorização da OEA, mas não da ONU.

$\mathrm{Na}$ área de pesquisas sobre as intervenções humanitárias atuais o seu potencial é grande, tendo em vista que o cenário internacional parece cada vez menos propenso a operações multilaterais ao velho estilo da paz liberal. O intervencionismo dificilmente deixará de ser uma realidade, mas é de se esperar que seja a cada dia mais praticado mediante formatos alternativos. O Haitianismo oferece ferramentas para a análise crítica destas formas emergentes, como as que giram em torno da Paz Híbrida ou de novas intervenções militares Sul-Sul.

Da mesma forma, na área de estudos sobre segurança pública, o Haitianismo possui potencial heurístico para enriquecer pesquisas sobre a complexidade crescente dos 'modelos' empregados em diversas partes do mundo pós-colonial. Além de fornecer instrumentos de análise capazes de dar conta dos bumerangues entre dispositivos de poder internos e externos aos Estados, também se apresenta como útil para a abordagem de políticas de (in)segurança cujo recorte sociorracial é evidente, mas nos quais as tecnologias de controle não são óbvias. Com o Haitianismo em mente, pode-se analisar criticamente não apenas projetos como as UPPs, mas também sua transição, mais ou menos abrupta, em direção a modelos explicitamente letais. Por meio de análises genealógicas, como a sugerida nesta tese, é possível resistir ao poder de discursos sobre inovações securitizantes que reivindiquem supostas democracias raciais, ao mesmo tempo em que se reconhece as lacunas, inversões e deslocamentos frente a modelos anteriormente empregados, porém reativados em novos cenários. 
Por fim, o Haitianismo, entendido como dispositivo de poder, permite seguir analisando - e resistindo - aos processos de militarização que avançam nas sociedades do Sul global. Com a libertação dos saberes referentes às técnicas de poder do Haitianismo se está mais equipado para lidar com a crescente intromissão militar em dimensões que estão além de suas prerrogativas, desde a academia até o mundo político-eleitoral. Como demonstrado pelo caso da MINUSTAH, a humanização das Forças Armadas brasileiras via o comando de uma intervenção que se apresentou como humanitária (a tautologia é proposital) abriu caminho para um crescente emprego de 'soluções' militares para problemas de relações humanas em âmbito doméstico, como as intervenções militares em entes federativos e operações de Garantia da Lei e da Ordem, no caso do Brasil. No entanto, esta colonização militar de novos âmbitos da vida social, política e cultural não é exclusividade deste país. O Haitianismo obriga a encarar criticamente não somente o biopoder, mas a colonialidade que é constitutiva desta tendência. Há grandes avenidas de investigação a serem percorridas neste sentido.

Aníbal Quijano (2000; 2005), criador do conceito de colonialidade do poder, o entende como a manutenção de traços específicos do padrão de poder estabelecido na era colonial ibero-americana, mas que continuam vigentes, ou são reativados, após os processos de independência formal. O Haitianismo é um destes traços. Conforme visto ao longo desta tese, desde clássicos do pensamento social brasileiro até intelectuais do Exército, passando inclusive por teóricos pós-coloniais de Relações Internacionais, todos convergem para a reativação do poder gerencial do sujeito brasileiro em posição de autoridade. Sujeitos que são capazes de evitar revoltas, dissipar resistências e aumentar a resiliência de liberalismos complexos, como aquele que convive com a escravidão no século XIX, ou aquele que empresta novo fôlego às intervenções da paz liberal do século XXI. ${ }^{323}$

$\mathrm{Na}$ disciplina de Relações Internacionais, é conhecida a distinção feita por Robert Cox (1981) entre teorias críticas e teorias de resolução de problemas. Há um risco de que as novas abordagens sobre as intervenções humanitárias sejam transformadas em maneiras sofisticadas de resolver os problemas mais evidentes da paz liberal como forma de perpetuar, grosso modo, as mesmas práticas

\footnotetext{
${ }^{323}$ Gilberto Freyre (2004) conclui que isto foi "uma dessas expressões de gênio político aplicada à administração das colônias", pois logrou que não se encontrasse "nunca entre nós ambiente tão favorável ao ódio do escravo contra o senhor, do preto contra o branco" (2004, p. 136).
} 
intervencionistas de sempre. Contudo, esta paz perpétua, assim como a de Kant (2008), pressupõe uma guerra perpétua contra o Outro. Diante destas observações, espera-se ter demonstrado, ao longo desta tese, a serventia analítica, assim como a importância política, que o engajamento com a formação discursiva do Haitianismo pode trazer. 


\section{REFERÊNCIAS BIBLIOGRÁFICAS}

ABDENUR, A.; CALL, C. A "Brazilian way"? Brazil's approach to peacebuilding. Order from Chaos - Foreign Policy in a Troubled World. Brookings Institute. Geoeconomics and global issues. Paper 5, February, 2017.

ABDENUR, A.; HAMANN, E. O futuro do Brasil nas operações de manutenção de paz da ONU. Le Monde Diplomatique, 12/04/2017. Disponível em:

$<$ https://diplomatique.org.br/o-futuro-do-brasil-nas-operacoes-demanutencao-da-paz-da-onu/>. Acesso em: 5 dez. 2018.

ACHING, G. On colonial modernity: civilization versus sovereignty in Cuba, c. 1840. In: Shilliam, R. (Ed.). International Relations and Non-Western Thought: Imperialism, colonialism and investigations of global modernity. London/New York: Routledge, 2011.

AGAMBEN, G. Homo Sacer: o poder soberano e a vida nua. Belo Horizonte: Editora UFMG, 2002.

. O que é um dispositivo?. Outra Travessia - Revista de Literatura PPGL/UFSC, n. 5, p. 9-16, 2ํㅗㄴ semestre de 2005.

AMIN, S. Eurocentrism: Modernity, Religion, and Democracy - A Critique ofEurocentrism and Culturalism. New York: Monthly Review Press, 2009.

AMORIM, C. Discurso do Ministro das Relações Exteriores, Embaixador Celso Amorim, na sessão de abertura da Reunião Internacional de Alto Nível sobre o Haiti. Brasília: Ministério das Relações Exteriores, 23 de maio de 2006. Disponível em: <http://www.itamaraty.gov.br/ptBR/discursos-artigos-e-entrevistas-categoria/7826-discurso-do-ministrodas-relacoes-exteriores-embaixador-celso-amorim-na-sessao-deabertura-da-reuniao-internacional-de-alto-nivel-sobre-o-haiti-brasilia-23de-maio-de-2006>. Acesso em: 18 dez. 2018.

Texto de base para a intervenção do Ministro Celso Amorim na Conferência Ministerial Preparatória sobre o Haiti - Montreal, 25/01/201. In: Resenha de Política Exterior do Brasil / Ministério das Relações Exteriores, Departamento de Comunicações e Documentação: Coordenação-Geral de Documentação Diplomática. Número 106, Ano 37, $1^{\circ}$ semestre de 2010.

ANAM, S. Peacebuilding: the Shift towards a Hybrid Peace Approach. Global \& Strategis, vol. 9, n. 1, p. 37-48, 2015. 
ANDRADA E SILVA, J. B. Representação à assembleia geral constituinte e legislativa do Império do Brasil sobre a escravatura. In: SILVA, E.; NEVES, G. R.; MARTINS, L. B. (Orgs.). José Bonifácio: A defesa da soberania nacional e popular - Coleção O Pensamento Político Brasileiro, vol. 6. Brasília: Fundação Ulysses Guimarães, 2011.

ANDRADE, H. Intervenção cede blindados do Haiti ao Bope com aparato menos letal. FOLHA DE S. PAULO. 28/03/2018. Disponível em: $<$ https://www1.folha.uol.com.br/cotidiano/2018/03/intervencao-cedetanques-do-haiti-ao-bope-com-aparato-menos-letal.shtml>. Acesso em: 18 dez. 2018.

ANDRADE, M. Imprensa moderada e escravidão: o debate sobre o fim do tráfico e o temor do haitianismo no Brasil Regencial (1831-1835). Anais do 4 Encontro Escravidão e Liberdade no Brasil Meridional. Curitiba: 1315/maio, 2009.

ANDRADE, M.; SILVA, J. Moderados, Exaltados e Caramurus no prelo carioca: os embates e representações de Evaristo da Veiga (1831-1835). Almanack, n.4, p. 130-148, 2ํㅗ semestre, 2012.

ANDREWS, G. Democracia racial brasileira 1900-1990: um contraponto americano. Estudos Avançados, vol. 11, n. 30, p. 95-115, 1997.

ARAÚJO, C. et al. Cidades negras: Africanos, crioulos e espaços urbanos no Brasil escravista do século XIX. 2. ed. São Paulo: Alameda, 2006.

ARAÚJO, R. Jubileu Sul participará de audiência sobre Haiti marcada para próxima segunda-feira. HAITI NO MINUSTAH. 30/07/2015. Disponível em: $<$ https://haitinominustah.info/2015/07/30/jubileu-sul-brasil-participara-deaudiencia-sobre-haiti-marcada-para-proxima-segunda-feira-3/>. Acesso em: 20 dez. 2018.

ARAÚJO, V. General da Brigada Paraquedista que já comandou as tropas brasileiras no Haiti vai comandar a Força de Paz no Alemão. EXTRA NOTÍCIAS RIO. 08/12/2010. Disponível em: $<$ https://extra.globo.com/noticias/rio/general-da-brigada-paraquedista-queja-comandou-as-tropas-brasileiras-no-haiti-vai-comandar-forca-de-paz-noalemao-184189.html>. Acesso em: 20 dez. 2018.

Comandante da Força de Paz no Complexo do Alemão promete rigor contra abusos por parte de. O GLOBO - RIO. 10/12/2010. Disponível em: $\quad<$ https://oglobo.globo.com/rio/comandante-da-forca-de-paz-nocomplexo-do-alemao-promete-rigor-contra-abusos-por-parte-de2913179 >. Acesso em: 20 dez. 2018.

ASHLEY, R. Untying the sovereign state: a double-reading of the anarchy problematique. Millennium - Journal of International Studies, vol. 17, n.2, p. 227-262, 1988. 
AZEVEDO, C. Onda Negra, Medo Branco: O Negro no Imaginário das Elites - Século XIX. 3. ed. São Paulo: Annablume, 2004.

BALIBAR, E. Is there a neo-racism?. In: BALIBAR, E.; WALLERSTEIN, I. (Eds.). Race, Nation, Class: Ambiguous Identities. London: Verso, 1991.

BANDAU, A. The Narrations of the Destruction of Saint-Domingue in the late $18^{\text {th }}$ Century and their Reinterpretations after the Bicentennial of the Haitian Revolution. L’Ordinaire des Amériques [en ligne], vol. 215, 2015.

BARROS, R. et al. A Medicina Veterinária Militar Brasileira em Operações de Paz: Experiências Colhidas na Missão da Organização das Nações Unidas para Estabilização do Haiti. Coleção Meira Mattos: revista das Ciências Militares - ECEME, vol. 7, n. 29, pp. 121-129, maio/agosto, 2013.

BASILE, M. Sociabilidade e ação políticas na Corte Imperial: a Sociedade Defensora da Liberdade e Independência Nacional. Dimensões: Revista de História da UFES, n.18, p. 349-383, 2006.

BBC NEWS. Oxfam sex scandal: Haiti suspends charity's operation, 22/02/2018. BBC News UK [online], February 2018. Disponível em: $<$ https://www.bbc.com/news/uk-43163620>. Acesso em: 15 dez. 2018.

BEIER, J. Beyond hegemonic state(ment)s of nature: indigenous knowledge and non-state possibilities in international relations. In: CHOWDHRY, G.; NAIR, S. (Eds.). Power, Postcolonialism and International Relations: Reading Race, Gender and Class. London: Routledge, 2002.

BERBEL, M.; MARQUESE, R. The Absence of Race: Slavery, Citzenship, and Pro-Slavery Ideology in the Cortes of Lisbon and the Rio de Janeiro Constituent Assembly (1821-4). Social History, vol. 32, n. 4, p. 415-433, 2007.

BERGIER, C. O Viva Rio inova há 20 anos, quando juntou intelectuais e lideranças comunitárias contra a violência no Rio. DRAFT - NEGÓCIOS SOCIAIS. 18/05/2015. Disponível em: <https://projetodraft.com/o-viva-rioinova-ha-20-anos-quando-juntou-intelectuais-e-liderancas-comunitariascontra-a-violencia-no-rio/>. Acesso em: 20 dez. 2018.

BEZERRA NETO, J. Ousados e insubordinados: protesto e fugas de escravos na província do Grão-Pará - 18 40/1860. Topoi, vol. 2, n.2, p. 73112, 2001.

- O Africano indesejado: combate ao tráfico, segurança pública e reforma civilizadora (Grão-Pará, 1850-1860). Afro-Ásia, n.44, p. 171-217, 2011.

BHABHA, H. Culture's in between. In: DU GAY, P.; HALL, S. (Eds.). Questions of Cultural Identity. London: Sage, 1996. 
BHABHA, H. The location of Culture. London: Routledge, 1994.

BHUTA, N. Against State-Building. Constellations, vol. 15, n. 4, p. 517542, 2008.

BLACKBURN, R. Haiti, Slavery, and the Age of the Democratic Revolution. William and Mary Quarterly, 3d series, vol. LXIII, n. 4, October, 2006.

BLANCO, R.; GUERRA, L. A Minustah como uma missão civilizadora: uma análise crítica da política internacional para estabilização do Haiti. Revista de Estudos Internacionais, vol. 8, n. 3, p. 259-275, 2017.

BLANEY, D.; YNAYATULLAH, N. International Relations and the problem of difference. New York: Routledge, 2004.

BONILLA, Y. Ordinary Sovereignty. Small Axe: A Caribbean Journal of Criticism, vol. 13, n.3, issue 42, November, 2013.

BORBA DE SÁ, M. Haitianismo: medo e ação das elites na produção do Brasil. Anais do $3^{\circ}$ Seminário de Graduação e Pós-graduação em Relações Internacionais: "Repensando interesses e desafios para a inserção internacional do Brasil no século XXI". ABRI - Florianópolis, 2930 de setembro de 2016.

. "Sucesso" e "Sacrifício" nas intervenções militares brasileiras: Haiti e Rio de Janeiro no século XXI. Rede Jubileu Sul Brasil - Artigos, 19/07/2018.

BORBA DE SÁ, M.; SAID, M.; WANSETTO, R. Militarização Tipo Exportação: o perigo da Indústria Humanitária brasileira. Le Monde Diplomatique, $\quad 04 / 05 / 2017 . \quad$ Disponível em: $<$ https://diplomatique.org.br/militarizacao-tipo-exportacao-o-perigo-daindustria-humanitaria-brasileira/>. Acesso em: 15 dez. 2018.

BRABAT 19 - Revista do 19 Contingente Brasileiro de Missão de Paz. Brasília: Helo Gráfica e Editora Ltda, maio de 2014.

BRAENGCOY - Construindo a Paz. Agenda Permanente. Companhia de Engenharia de Força de Paz - Haiti, s.e, s/d.

BRAGA, C. Os desafios iniciais da participação das Forças Armadas Brasileiras na MINUSTAH. In: HAMANN, E.; TEIXEIRA, C. (Orgs.). A participação do Brasil na MINUSTAH (2004-2017): percepções, lições e práticas relevantes para futuras missões. Edição especial - coletânea de artigos. Rio de Janeiro: Igarapé/CCOPAB, 2017.

BRASIL. Anais do Parlamento Brasileiro. Sessões de 23/06/1848 e 27/06/1848. 
BRASIL. Manifesto de 06 de Agosto de 1822. Legislação. Coleção Leis do Império - 06/08/1822, p. 132, vol. 1.

. Lei o 4 de 10 de Junho de 1835. Presidência da República - Casa

Civil. Subchefia para Assuntos Jurídicos. Sellada e Publicada na Chancellaria do Imperio em 15 de junho de 1835.

BRICMONT, J. Humanitarian Imperialism: Using Human Rights to Sell War. New York: Monthly Review Press, 2007.

BRINKMANN, S.; KVALE, S. Interviews: Learning the Craft of Qualitative Research Interviewing. Thousand Oaks: SAGE Publications, 2009.

BRITO, L. Sob o Rigor da Lei: Os Africanos e a Legislação Baiana no Século XIX. Sankofa - Revista de História da África e de Estudos da Diáspora Africana. n.2, dez., 2008.

BUCK-MORSS, S. Hegel e Haiti. Novos Estudos CEBRAP. ed. 90, vol. 30, n.2, p. 131-171, julho, 2011.

BUFFET, P. The Charitable-Industrial Complex. New York Times, July $26^{\text {th }}$ 2013.

CÂMARA CASCUDO, L. Geografia dos Mitos Brasileiros. 2. ed. São Paulo: Global, 2002.

CÂMARA, I. Em nome da democracia: a OEA e a crise Haitiana (19911994). Brasília: Instituto Rio Branco, 1998.

CÂMARA MUNICIPAL DE SÃO PAULO. Audiência Pública discute retirada das tropas do Haiti. Notícias - Da Redação, 14/10/2015. Disponível em: $<$ http://www.saopaulo.sp. leg.br/blog/audiencia-publica-discute-a-retiradade-tropas-do-haiti/>. Acesso em: 20 dez. 2018.

CANCLINI, N. Hybrid Cultures: Strategies for Entering and Leaving Modernity, Minneapolis: University of Minnesota Press, 2005.

Culturas Híbridas: Estratégias para entrar e sair da modernidade. 4. ed. São Paulo: Editora da Universidade de São Paulo, 2015.

CARDOSO, A. Escravidão e sociabilidade capitalista: um ensaio sobre inércia social. Novos Estudos CEBRAP, ed. 80, vol. 27, n.1, março, 2008.

CARPENTIER, A. O reino deste mundo. São Paulo: Martins Fontes, 2009.

CARTA CAPITAL. Haiti - especiais. Disponível em: $<$ https://www.cartacapital.com.br/tag/haiti/>. Acesso em: 20 dez. 2018.

CARVALHO, J. M. A construção da ordem: a elite política imperial. Teatro de sombras: a política imperial. Rio de Janeiro: Civilização Brasileira, 2014. 
CARVALHO, J. M. História Intelectual no Brasil: a retórica como chave de leitura. Topoi, vol. 1, n. 1, p. 123-152, 2000.

CARVALHO, J.; COELHO, H. Nova Clínica da Família do Rio será gerida por OS investigada pelo MP-RJ. G1 - GLOBO - Rio. 19/01/2016. Disponível em: <http://g1.globo.com/rio-de-janeiro/noticia/2016/01/novaclinica-da-familia-sera-gerida-por-os-investigada-pelo-mp-ri.html>. Acesso em: 15 dez. 2018.

CARVALHO, M. J. Hegemony and Rebellion in Pernambuco (Brazil), 1824-1835. Tese de Doutorado - University of Illionois Urbana-Champaign, 1989.

CARVALHO, V. A música brasileira na MINUSTAH: a arte do soldado como diplomacia. In: HAMANN, E.; TEIXEIRA, C. (Orgs.). A participação do Brasil na MINUSTAH (2004-2017): percepções, lições e práticas relevantes para futuras missões. Edição especial - coletânea de artigos. Rio de Janeiro: Igarapé/CCOPAB, 2017.

CASTRO, A. Exército Brasileiro: "Braço Forte, Mão Amiga". EBLOG - Blog do Exército Brasileiro. 22/01/2018. Disponível em: $<$ http://eblog.eb.mil.br/index.php/menu-easyblog/exercito-brasileiro-bracoforte-mao-amiga.html>. Acesso em: $18 \mathrm{dez} .2018$.

CASTRO-GÓMEZ, S. Ciências sociais, violência epistêmica e a "invenção do outro". In: LANDER, E. (Org.). A colonialidade do saber: eurocentrismo e ciências sociais - perspectivas latino-americanas. Buenos Aires: CLACSO, 2005.

. Michel Foucault y la colonialidad del poder. Tabula Rasa, n. 6, p. 153-172, Enero-Junio, 2007.

CASTRO-GÓMEZ, S.; GROSFOGUEL, R. (Orgs.). El giro decolonial: reflexiones para una diversidad epistémica más allá del capitalismo global. Bogotá: Siglo del Hombre Editores, 2007.

CHAKRAVARTI, S. Sing the rage: Listening to Anger After Mass Violence. Chicago: University of Chigado Press, 2014.

CHANDLER, D. Empire in denial: the politics of State-building. London: Pluto Press, 2006.

From Kosovo to Kabul and Beyond: Human Rights and International Intervention. London: Pluto Press, 2002

Theorising the shift from security to insecurity - Kaldor, Duffield and Furedi. Review Article. Conflict, Security \& Development, vol. 8, n.2, June, 2008. 
CHOMSKY, N. Humanitarian imperialism: The New Doctrine of Imperial Right. Monthly Review, v. 60, n. 4, 2008.

CLAUHS, A. Os Impactos da Formação Multiétnica na Liderança Militar Brasileira em Missões de Paz. Coleção Meira Mattos: revista das Ciências Militares - ECEME, vol. 7, n. 29, pp. 99-111, maio/agosto, 2013.

COELHO, H.; MARTINS, M. Interventor Federal diz que 'Rio é um laboratório para o Brasil'. G1- Globo - Rio de Janeiro. 27/02/2018. Disponível em: <https://g1.globo.com/ri/rio-de-janeiro/noticia/autoridadesdetalham-medidas-da-intervencao-federal-o-rio-de-janeiro.ghtml>. Acesso em: 19 dez. 2018.

COLUNA DO FRAGA. Intervenção no Rio tem que ser "curta e contundente", diz general. R7 Notícias. 20/02/2018. Disponível em: $<$ https://noticias.r7.com/prisma/coluna-do-fraga/intervencao-no-rio-temque-ser-curta-e-contundente-diz-general-20022018>. Acesso em: 17 dez. 2018.

CONSTANTINOU, C.; OPONDO, S. Engaging the 'ungoverned': The merging of diplomacy, defence and development. Cooperation and Conflict, vol. 51, n. 3, p. 307-324, 2016.

COOPER, N.; PUGH, M.; TURNER, M. The end of history and the last peacebuilder: a reply to Roland Paris. Review of International Studies, vol. 30, n. 4, p. 1995-2007, October, 2011.

COSTA, W. Trabalho Emocional dos Militares do Exército Brasileiro nas Missões de Paz das Nações Unidas. Coleção Meira Mattos: revista das Ciências Militares - ECEME, vol. 7, n. 29, p. 139-145, maio/agosto, 2013.

COX, R. Social Forces, States and World Orders: Beyond International Relations Theory. Millennium - Journal of International Studies, vol. 10, n. 2, p. 126-155, 1981.

DE ROCCHI, D. Minustah: avanços e desafios 10 anos depois. Anais da X Semana de Extensão, Pesquisa e Pós-Graduação - SEPesq - Centro Universitário Ritter dos Reis, 20-24 de outubro, 2014.

DIAS, C. O Vizinho que ninguém quer ter. O Estado de S. Paulo, 16/01/2010. Disponível em: <https://www.estadao.com.br/noticias/geral,ovizinho-que-ninguem-quer-ter,496960>. Acesso em: $18 \mathrm{dez}$. 2018.

DILLON, M.; REID, J. The Liberal Way of War: killing to make life live. London/New York: Routledge, 2009.

DODDS, P. AP Exclusive: UN child sex ring left victims but no arrests. Associated Press, 12/04/2017. Disponível em: $<$ https://apnews.com/e6ebc331460345c5abd4f57d77f535c1>. Acesso em: 14 dez. 2018. 
DOTY, R. Imperial Encounters: The Politics of Representation in NorthSouth Relations. 1 ed. Minneapolis: University of Minnesota Press, 1996.

. The bounds of race in International Relations. Millennium:

Journal of International Studies, vol. 22, n. 3, p. 443-461, Dec., 1993.

DREIFUSS, R. A Internacional Capitalista: estratégia e táticas do empresariado transnacional (1918-1986). Rio de Janeiro: Espaço e Tempo, 1987.

DUARTE, M.; PINHEIRO, P. O canto das três raças. In: NUNES, C. 0 Canto das Três Raças. Rio de Janeiro: EMI-Odeon, 1976.

DUBOIS, L. Avengers of the new world: the story of the Haitian Revolution. Cambridge: The Belknap Press of Harvard University Press, 2004.

. David Geggus - Haitian Revolutionar Studies. France Review, vol. 3, n. 7. February, 2003.

DUBOIS, L.; SCOTT, J. (Eds.). Origins of the Black Atlantic. New York: Routledge, 2010.

DUFFIELD, M. Development, Security and Unending War: Governing the Wolrd of Peoples. Malden: Polity Press, 2007.

Global Governance and the new Wars: The Merger of Development and Security. London: Zed Books, 2001.

. Human Security: Linking Development and Security in an Age of Terror. In: New Interfaces between Security and Development (panel). Bonn: 11 ${ }^{\text {th }}$ General Conference of the EADI, 21-24 September, 2005.

EISENBERG, P. Prefácio. In: AZEVEdo, C. M. Onda Negra, Medo Branco: O Negro no Imaginário das Elites - Século XIX. 3. ed. São Paulo: Annablume, 2004 [prefácio de 1987].

ESCOBAR, A. Encountering Development: The Making and Unmaking of the Third World. Princeton, NJ: Princeton University Press, 1995.

. O lugar da natureza e a natureza do lugar: globalização ou pósdesenvolvimento?. In: LANDER, E. (Org.). A colonialidade do saber: eurocentrismo e ciências sociais - perspectivas latino-americanas. Buenos Aires: CLACSO, 2005.

ESTARQUE, M. Missão no Haiti torna Brasil referência em treinamento de forças de paz. DW - MUNDO. 23/12/2014. Disponível em: $<$ https://www.dw.com/pt-br/miss\%C3\%A3o-no-haiti-torna-brasilrefer\%C3\%AAncia-em-treinamento-de-for\%C3\%A7as-de-paz/a18141833 >. Acesso em: 19 dez. 2018. 
FACCHINI, J.; TOLEDO, A. Da transformação de conflitos à paz híbrida: uma análise das ideias de Paul Lederach e Roger Mac Ginty. Revista Brasileira de Estudos de Defesa, vol. 4, n. 2, p. 153-174, jul./dez., 2017.

FANON, F. Os condenados da terra. Juiz de Fora: UFJF, 2005.

FARIA, A. Senador haitiano pede apoio à retirada das tropas da ONU do Haiti. Rádio Senado - Senado Federal. 21/05/2014. Disponível em: $<$ https://www12.senado.leg.br/radio/1/noticia/senador-haitiano-pedeapoio-a-retirada-das-tropas-da-onu-do-haiti>. Acesso em: 13 dez. 2018.

FELLET, J. Haiti se tornou laboratório para Brasil, diz embaixador. BBC News - Brasil. Disponível em: $<$ https://www.bbc.com/portuguese/noticias/2012/02/120228 haiti entrevist a embaixador jif $>$. Acesso em: 13 dez. 2018.

FERNANDES, R. C. Respeito e honra ao Haiti. In: HAMANN, E.; TEIXEIRA, C. (Orgs.). A participação do Brasil na MINUSTAH (2004-2017): percepções, lições e práticas relevantes para futuras missões. Edição especial - coletânea de artigos. Rio de Janeiro: Igarapé/CCOPAB, 2017.

FERREIRA, R.; GOMES, F. A Miragem da Miscigenação. Novos Estudos CEBRAP, ed. 80, vol. 27, n. 1, março, 2008.

FERRER, A. A sociedade escravista cubana e a Revolução Haitiana. Almanack, n. 3, p. 37-53, 1ํㅗㄴ semestre de 2012.

FINNEMORE, M. Constructing norms of humanitarian intervention. In: KATZENSTEIN, P. (Ed.). The culture of national security: norms and identity in world politics. New York: Columbia University Press, 1996.

FISCHER, S. Modernity Disavowed: Haiti and the Cultures of Slavery in the Age of Revolution. Durham: Duke University Press, 2004.

FLORY, T. Race and Social Control in Independent Brazil. Journal of Latin American Studies, vol. 9, n. 2, p. 199-224, nov., 1977.

FOLHA DE S. PAULO. Cabral apóia aborto e diz que favela é fábrica de marginal. Folha - Cotidiano - Sucursal do Rio. 20/10/2007. Disponível em: $\quad<$ https://www1.folha.uol.com.br/fsp/cotidian/ff2510200701.htm>. Acesso em: 20 dez. 2018.

FONTENELE, C. Campanha intensifica pressão pela retirada das tropas brasileiras do Haiti. Centro de Estudos das Relações de Trabalho e Desigualdade, 21/05/2015. Disponível em: $<$ https://www.ceert.org.br/noticias/direitos-humanos/6988/campanhaintensifica-pressao-pela-retirada-das-tropas-brasileiras-do-haiti>. Acesso em: 18 dez. 2018. 
FOUCAULT, M. A arqueologia do saber. 8 ed. Rio de Janeiro: Forense Universitária, 2016.

."É preciso defender a sociedade": Curso no Collège de France (1975-1976). Lisboa: Editora Livros do Brasil, 2006.

. Microfísica do Poder. 2. ed. Rio de Janeiro: Edições Graal, 1979.

. Vigiar e Punir: o nascimento da prisão. Petrópolis: Vozes, 1987.

FOX, G. Humanitarian Occupation. Cambridge: Cambridge University Press, 2008.

FRANCO, M. UPP - A redução da favela a três letras: uma análise da política de segurança pública do Estado do Rio de Janeiro. São Paulo: N-1 Edições, 2018.

FREITAS, D. A Miserável Revolução das Classes Infames. Rio de Janeiro: Record, 2005.

. Os guerrilheiros do imperador. Rio de Janeiro: Graal, 1978.

FREITAS, S. "Qual silêncio?" O Haiti nas páginas dos primeiros periódicos brasileiros. São Paulo: Anais do XXVI Simpósio Nacional de História ANPUH, julho de 2011.

FREYRE, G. Nordeste: aspectos da influência da cana sobre a vida e a paisagem do Nordeste do Brasil. São Paulo: Global, 2004.

G1 - GLOBO. "Haiti se tornou laboratório para Brasil", diz embaixador. G1 - Mundo. 29/02/2012. Disponível em: $<$ http://g1.globo.com/mundo/noticia/2012/02/haiti-se-tornou-laboratoriopara-o-brasil-diz-embaixador.html>. Acesso em: 2 dez. 2018.

G1 - RJ2. Prefeitura encerra contrato com OS que administrava Hospital Ronaldo Gazzola, no Rio. G1 - GLOBO. 29/10/2018. Disponível em: $<$ https://g1.globo.com/ri/rio-de-janeiro/noticia/2018/10/29/prefeituraencerra-contrato-com-os-que-administrava-hospital-ronaldo-gazzola-norio.ghtml>. Acesso em: 13 dez. 2018.

GALEANO, E. Haití, país ocupado. Página 12. (Texto leído por el escritor uruguayo en la Biblioteca Nacional [Uruguay] en el marco de la mesadebate "Haití y la respuesta latinoamericana"), en 27/09/2011. Disponível em: <https://www.pagina12.com.ar/diario/contratapa/13-177742-2011-0928.html>. Acesso em: 20 jun. 2018.

GEGGUS, D. Equality, Slavery and Colonial Secession during the Constituent Assembly. The American Historical Review, vol. 94, n. 5, p. 1290-1308, dec. 1989. 
GEGGUS, D. Jamaica and the Saint Domingues lave revolt, 1791-1793. The Americas, vol. 38, n.2, p. 219-233,1981.

p. 43-68, 1997.

The Naming of Haiti. New West Indian Guide, vol. 71, n. 1 \& 2,

GENOVESE, E. From rebellion to revolution: afro-american slave revolts in the making of the modern world. Baton Rouge/London: Louisiana State University Press, 1979.

GILROY, P. O Atlântico Negro: modernidade e dupla consciência. São Paulo: Editora 34/ Rio de Janeiro: Universidade Cândido Mendes, Instituto de Estudos Afro-Asiáticos, 2001.

GOMES, A. Da Paz Liberal à Virada Local: Avaliando a Literatura Crítica sobre Peacbuilding. Monções: Revista de Relações Internacionais da UFGD. Dourados, vol. 2, n. 3, p. 46-76, jul./dez., 2013.

GOMES, F.; SOARES, C. Sedições, Haitianismo e Conexões no Brasil Escravista: outras margens do Atlântico Negro. Novos Estudos CEBRAP, n. 63, vol. 2, p. 131-144, julho de 2002.

GOMES, F. Experiências transatlânticas e significados locais: idéias, temores e narrativas em torno do Haiti no Brasil Escravista. Revista Tempo, vol. 7, n. 13, p. 209-246, julho, 2002.

GOMES, M. A "pacificação" como prática de "política externa" de (re)produção do self estatal: rescrevendo o engajamento do Brasil na Missão das Nações Unidas para a Estabilização no Haiti (MINUSTAH). Rio de Janeiro, 2014. 271p. Tese de doutorado - Pontifícia Universidade Católica do Rio de Janeiro, Instituto de Relações Internacionais. Orientadora: Mônica Herz.

GÓMEZ, A. El síndrome de Saint-Domingue. Percepciones y sensibilidades de la Revolución Haitiana en el Gran Caribe (1791-1814). C.M.H.L.B. Caravelle, n. 86, p. 125-155, Toulouse, 2006.

. From the Haitian fear to the Syndrome of Saint-Domingue. Lecture at Brown University, February, mimeo, p. 1-9, 2004.

GREENBURG, J. The "Strong Arm" and the "Friendly Hand": military humanitarianism in Post-Earthquake Haiti. Journal of Haitian Studies, vol. 19, n. 1, p. 60-87, 2013.

GRIECO, J. Anarchy and the limits of cooperation: a realist critique of the newest liberal institutionalism. In: BALDWIN, D. (Ed.). Neorealism and Neoliberalism: The Contemporary Debate. New York: Columbia University Press, 1993. 
GROVOGUI, S. Beyond Eurocentrism and anarchy: memories of International order and institutions. New York: Palgrave Macmillan US, 2006.

HALLWARD, P. Haitian inspiration: On the bicentenary of Haiti's independence. Radical Philosophy, n. 123, p. 2-7, Jan./Feb., 2004.

HAMANN, E.; CEZNE, E. Brazilian Peacekeeping: Challenges and Potentials in Turbulent Landscapes at Home and Internationally. PRIO Policy Brief, n. 22, 2016.

HAMANN, E.; TEIXEIRA, C. (Orgs.). A participação do Brasil na MINUSTAH (2004-2017): percepções, lições e práticas relevantes para futuras missões. Edição especial - coletânea de artigos. Rio de Janeiro: Igarapé/CCOPAB, 2017.

HEATHERSHAW, J. Unpacking the Liberal Peace: The Dividing and Merging of Peacebuilding Discourses. Millennium: Journal of International Studies. Vol. 36, n. 3, p. 597-622, 2008.

The Practical Representation of Peacebuilding: An (Auto)ethnography of Programme Evaluation in Tajikistan. In: MITCHELL, A.; RICHMOND, O. Hybrid forms of peace: from everyday agency to postliberalism. London: Palgrave Macmillan, 2012.

HEINE, J.; THOMPSON, A. Fixing Haiti: MINUSTAH and beyond. Tokyo/New York/Paris: United Nations University Press, 2011.

HENRIQUES, J. Racismo em português: O lado esquecido do colonialismo. Rio de Janeiro: Tinta da China, 2017.

HÉRBARD, J. Slavery in Brazil: Brazilian Scholars in Key Interpretative Debates. Translating the Americas, vol. 1, p. 47-95, 2013.

HERMANN, B. Soberania, não intervenção e não indiferença: reflexões sobre o discurso diplomático brasileiro. Brasília: FUNAG, 2011.

HERZ, A.; IVES, K. Wikileaks Haiti: The Aristide files. The Nation. 05/08/2011.

HIRST, M. Aspectos conceituais e práticos da atuação do Brasil em cooperação sul-sul: os casos de Haiti, Bolívia e Guiné Bissau. Texto para Discussão, n. 1687. Rio de Janeiro: IPEA, janeiro de 2012.

HOBBES, T. Leviatã, ou Matéria, forma e poder de um Estado eclesiástico e civil. 2. ed. São Paulo: Martin Claret, 2012.

HOLLOWAY, T. Polícia no Rio de Janeiro: repressão e resistência numa cidade do século XIX. Rio de Janeiro: Fundação Getulio Vargas, 1997. 
HORKHEIMER, M. Critical Theory: Selected Essays. New York: Continuum International Publishing Group, 2002.

HUNTINGTON, S. Political order in changing societies. New Heaven/London: Yale University Press, 1968.

INFORMEX - A Palavra Oficial do Exército. № 005, 16 de fevereiro de 2018. (Assinado pelo Gen. Div. Otávio Santana do Rêgo Barros, Chefe do Centro de Comunicação Social do Exército).

IGNATIEFF, M. Nation-Building Lite. New York Times, July 28 2002.

INSTITUTO POLÍTICAS ALTERNATIVAS PARA O CONE SUL. Carta de Rechaço à renovação do mandato da MINUSTAH no Haiti. 07/10/2014.

Disponível em: <http://www.pacs.org.br/2014/10/07/carta-de-rechaco-arenovacao-do-mandato-da-minustah-no-haiti-america-latina-e-caribeoutubro-de-2014/>. Acesso em: 10 dez. 2018.

INTERNATIONAL COMMITTEE ON INTERVENTION AND STATE SOVEREIGNTY. Responsibility to Protect. Ottawa: International Development Research Centre, 2001.

JAHN, B. IR and the state of nature: the cultural origins of a ruling ideology. Review of International Studies, vol. 25, n. 3, pp. 411-434, jul.,1999.

JAMES, C. L. R. The Black Jacobins: Toussant L'ouverture and the San Domingo Revolution. $2^{\text {nd }}$ ed. New York: Vintage Books, 1989.

JOHNSON, C. Blowback: The Costs and Consequences of American Empire. New York: Henry Holt, 2000.

KALIL, M.; NAPOLEÃO, T. Stabilization as securitization of Peacebuilding? The experience of Brazil and MINUSTAH in Haiti. Brasiliana - Journal of Brazilian Studies, vol. 3, n. 2, p. 87-112, March, 2015.

KANT, I. A Paz Perpétua: Um Projecto Filosófico [1795]. Covilhã: LusoSofia Press, 2008.

KAWAGUTI, L. A República Negra: Histórias de um repórter sobre as tropas brasileiras no Haiti. Rio de Janeiro: Globo, 2006.

KENKEL, K. Interests, Identity and Brazilian Peacekeeping Policy. Perspective of the World Review, vol. 3, n. 2, p. 9-36, 2011.

KLEIN, N. The Shock Doctrine: the rise of disaster capitalism. London: Penguin Books, 2007.

KRISHNA, S. Globalization and Postcolonialism: Hegemony and Resistance in the Twenty-first Century. Lanham: Rowman \& Littlefield Publishers, 2009. 
KRISHNA, S. Race, Amnesia, and the Education of International Relations. In: JONES, B. Decolonizing International Relations. Lanham: Rowman \& Littlefields Publishers, 2006.

LANDER, E. Ciências sociais: saberes coloniais e eurocêntricos. In: LANDER, E. (Org.). A colonialidade do saber: eurocentrismo e ciências sociais - perspectivas latino-americanas. Buenos Aires: CLACSO, 2005.

LARNER, W.; WALTERS, W. Global Governmentality: Governing international spaces. London and New York: Routledge, 2004.

LEANDER, A. The politics of whitelisting: Regulatory work and topologies in commercial security. Environment and Planning D: Society and Space, vol. 34, n. 1, p. 48-66, 2016.

LEMAY-HÉBERT, N. United Nations Stabilisation Mission in Haiti (MINUSTAH). In: KOOPS, J.; MACQUEEN, N.; TARDY, T.; WILLIAMS, P. (Eds.). The Oxford Handbook of United Nations Peacekeeping Operations. Oxford: Oxford University Press, 2015.

LEON, J. Haïti: première victime de la tentation impériale du Brésil. Mondialisation: Centre de Recherche sur la Mondialisation, 04/07/2013. Disponível em: <https://www.mondialisation.ca/haiti-premiere-victime-dela-tentation-imperiale-du-bresil/5337637>. Acesso em: 7 jul. 2013.

LIPSET, S. Some Social Requisites for Democracy: Economic Development and Political Legitimacy. The American Political Science Review, vol. 53, n. 1, p. 69-105, March, 1959.

LOZANO, W.; MAINGOT, A. The United States and the Caribbean: transforming hegemony and sovereignty. New York/London: Routledge, 2005.

LUKÁCS, G. Ontologia do ser social: os princípios ontológicos fundamentais de Marx. São Paulo: Livraria Editora Ciências Humanas LTDA, 1979.

LULA DA SILVA, L. I. Não vamos nos esquecer do Haiti. EI País, OpiniãoTribuna, 25/02/2014. Disponível em: $<$ https://brasil.elpais.com/brasil/2014/02/25/opinion/1393359908 575387. html>. Acesso em: 20 dez. 2018.

. Discurso do Presidente Luiz Inácio Lula da Silva durante cerimônia de formatura das tropas brasileiras da Missão da ONU (Minustah) - Porto Príncipe, Haiti, 25/02/2010. In: Resenha de Política Exterior do Brasil / Ministério das Relações Exteriores, Departamento de Comunicações e Documentação: Coordenação-Geral de Documentação Diplomática. Número 106, Ano 37, 1ํsemestre de 2010. 
LULA DA SILVA, L. I. Discurso do Presidente da República, Luiz Inácio Lula da Silva, durante cerimônia de honras fúnebres aos militares mortos no cumprimento do dever na Missão de Paz no Haiti - Hangar da Base Aérea de Brasília - DF, 21/01/2010. In: Resenha de Política Exterior do Brasil / Ministério das Relações Exteriores, Departamento de Comunicações e Documentação: Coordenação-Geral de Documentação Diplomática. Número 106, Ano 37, 1ํ semestre de 2010.

MAC LEOD, J. From De-to-Post-to-Neo-Colonization: A Brief History of Haiti's Occupations. JDM, 10 Nov. 2011. Disponível em: $<$ www.jasonmacleod.com/?page id=175>. Acesso em: 15 jun. 2018.

MAC GINTY, R. International Peacebuilding and Local Resistance: hybrid forms of peace. London: Palgrave Macmillan, 2011.

MAC GINTY, R.; RICHMOND, O. The fallacy of constructing hybrid political orders: a reappraisal of the hybrid turn in peacebuilding. International Peacekeeping, vol. 23, n. 2, p. 1-21, 2015.

MALAGUTI BATISTA, V. O medo na cidade do Rio de Janeiro: dois tempos de uma história. Rio de Janeiro: Revan, 2014.

MARQUESE, R. Feitores do corpo, missionários da mente: senhores, letrados e o controle dos escravos nas Américas, 1660-1860. São Paulo: Companhia das Letras, 2004.

. The dynamics of slavery in Brazil: Resistance, the slave trade and manumission in the $17^{\text {th }}$ to $19^{\text {th }}$ centuries. Novos Estudos CEBRAP, vol. 2, special edition [inglês], 2006.

MARTINS, G.; SANTOS, J. Ditadura na democracia: Intervenção Militar no Rio de Janeiro causa aumento do extermínio nas favelas e periferias. Instituo PACS, 03/08/2018. Disponível em: $<$ https://medium.com/@pacsinstituto/ditadura-na-democracia9662afc05a58>. Acesso em: 20 dez. 2018.

MASLOW, A. A Theory of Human Motivation. Psychological Review, vol. 50, p. 370-396, 1943.

MATTOS, I. Construtores e herdeiros: a trama dos interesses na construção da unidade política. Almanack Brasiliense, vol. 1, n. 1, p. 826, maio, 2005.

O tempo saquarema: a formação do Estado imperial. 5. ed. São Paulo: Hucitec, 2004.

MAX, M. A Pacificação do Complexo do Alemão deu certo? VICE NOTÍCIAS. 30/11/2015. Disponível em: $<$ https://www.vice.com/pt br/article/53mevd/a-pacificacao-do-complexodo-alemao-deu-certo $>$. Acesso em: 15 dez. 2018. 
MEARSHEIMER, J. The False Promise of International Institutions. International Security, vol. 19, n. 3. p. 5-49, Winter, 1994-1995.

MELLO MOURÃO, G. A Revolução de 1817 e a História do Brasil: um estudo de história diplomática. Brasília: FUNAG e Ed. UnB, 2009.

MENDONÇA, M. Brasil no Haiti, um caso de sucesso: uma análise da missão brasileira no Haiti. In: HAMANN, E.; TEIXEIRA, C. (Orgs.). A participação do Brasil na MINUSTAH (2004-2017): percepções, lições e práticas relevantes para futuras missões. Edição especial - coletânea de artigos. Rio de Janeiro: Igarapé/CCOPAB, 2017.

MÉSZÁROS, I. O poder da ideologia. São Paulo: Boitempo Editorial, 2004.

MISSÃO INTERNACIONAL DE INVESTIGAÇÃO E SOLIDARIEDADE COM O HAITI. Haiti: Soberania e dignidade. Rede Jubileu Sul Américas. 17 min. Brasil, 2005.

MITCHELL, A.; RICHMOND, O. Hybrid forms of peace: from everyday agency to post-liberalism. London: Palgrave Macmillan, 2012.

MIGNOLO, W. Histórias locais/Projetos Globais: colonialidade, saberes subalternos e pensamento liminar. Belo Horizonte: UFMG, 2003.

Local Histories/Global Designs: Coloniality, Subaltern Knowledges, and Border Thinking. Princeton, NJ: Princeton University Press, 2000.

La Idea de América Latina: La herida colonial y la opción decolonial. Barcelona: Gedisa, 2007.

Delinking: The rethoric of modernity, the logic of coloniality and the grammar of de-coloniality. Cultural Studies, vol. 21, n. 2-3, March/May, p. 449-514, 2007.

MINTZ, S. Goodbye Columbus: Second Thoughts on the Caribbean Region at Mid-Millennium (Walter Rodney Memorial Lecture). Centre for Caribbean Studies: University of Warwick, May, 1993.

MOREL, M. A Revolução do Haiti e o Brasil escravista: o que não deve ser dito. Jundiaí, SP: Paco Editorial, 2017.

. O abade Grégoire, o Haiti e o Brasil: repercussões no raiar do século XIX. Almanack Braziliense, n. 2, p. 76-90, novembro de 2005.

MORENO, M.; BRAGA, C.; GOMES, M. Trapped Between Many Worlds: A Post-colonial Perspective on the UN Mission in Haiti (MINUSTAH). International Peacekeeping, vol. 19, n. 3, p. 377-392, 2012. 
MOTT, L. A Revolução dos Negros do Haiti e o Brasil. In: MOTT, L. Escravidão, Homossexualidade e Demonologia. São Paulo: Ícone, 1988.

MOURA, C. Rebeliões da Senzala. São Paulo: Edições Zumbi, 1959.

MÜLLER, M. M. Entangled pacifications: Peacekeeping, counterinsurgency and policing in Port-au-Prince and Rio de Janeiro. In: HONKE, J.; MÜLLER, M.M. The Global Making of Policing: Post-colonial perspectives. London/New York: Routledge, 2016.

MUNRO, M.; SHILLIAM, R. Alternative sources of cosmopolitanism: nationalism, universalism and Créolité in Francophone Caribbean thought. In: Shilliam, R. (Ed.). International Relations and Non-Western Thought: Imperialism, colonialism and investigations of global modernity. London/New York: Routledge, 2011.

MUPPIDI, H. Colonial Signs of International Relations. Oxford: Oxford University Press, 2012.

MURPHY, C. Global Institutions, Marginalization, and Development. London: Routledge, 2005.

NAÇÕES UNIDAS NO BRASIL. ONU e parceiros lançam campanha no Brasil em homenagem às forças de paz. ONUBR. 11/06/2018.

Disponível em: <https://nacoesunidas.org/onu-e-parceiros-lancamcampanha-no-brasil-em-homenagem-forcas-paz/>. Acesso em: $20 \mathrm{dez}$. 2018.

NASCIMENTO, W. "São Domingos, o grande São Domingos": repercussões e representações da Revolução Haitiana no Brasil escravista (1791-1840). Dimensões, vol. 21, p. 125-142, 2008.

NASSER, F. Projeção de Poder e Solidariedade na Estratégia Diplomática de Participação Brasileira em Operações de Paz da Organização das Nações Unidas. In: KENKEL, K.; MORAES, R. (Orgs.). O Brasil e as operações de paz em um mundo globalizado: entre a tradição e a inovação. Brasília: IPEA, 2012.

NEEDELL, J. The Party of Order: The Conservatives, the State and Slavery in the Brazilian Monarchy, 1831-1871. Stanford: Stanford University Press, 2006.

NISHIKAWA, R. O Haiti não é aqui: discurso antiescravista e práticas escravistas no Brasil (1790-1840). Métis: História \& Cultura, vol. 4, n. 7, p. 11-32, jan./jun., 2005.

NOGUEIRA, J. From Failed States to Fragile cities: Redefining spaces of humanitarian practice. Third World Quarterly, vol. 38, n. 7, p. 1437-1453, February, 2017. 
OPONDO, S.; SHAPIRO, M. Subalterns speak: migrant bodies, and the performativity of arts. Globalizations, June, 2018.

PARIS, R. Broadening the Study of Peace Operations. International Studies Review, vol. 2, n. 3, p. 27-44, Autumn, 2000.

. International Peacebuilding and the 'mission civilisatrice'. Review of International Studies, vol. 28, n. 4, p. 637-656, 2002.

Peacebuilding and the Limits of Liberal Internationalism. International Security, vol. 22, n. 2, p. 54-89, Fall, 1997.

. Saving Liberal Peacebuilding. Review of International Studies. vol. 36, n. 2, p. 337-365, April, 2010.

PATRICK, I. Aquilo que resta de nós: um pedido de socorro de haitianas estupradas por soldados da ONU. Belo Horizonte: Páginas, 2017.

PEARCE, J. Under The Eagle: U.S. intervention in Central America and the Caribbean. London: Latin American Bureau, 1981.

PECK, R. Las relaciones peligrosas (Prefácio a la edición en francés 2014). In: SEITENFUS, R. Reconstruir Haití: entre la esperanza y el tridente imperial. Santo Domingo: CLACSO/Fundación Juan Bosch, 2016.

PERCHELLET, S. Haïti: entre colonisation, dette et domination - deux siècles de luttes pour la liberté. Liège e Port-au-Prince: CADTM/PAPDA, 2010.

PERSAUD, R. Situating Race in International Relations: the dialects of civilizational security in American immigration. In: CHOWDHRY, G.; NAIR, S. (Eds.). Power, Postcolonialism and International Relations: Reading Race, Gender and Class. London: Routledge, 2002.

PLATAFORMA DE ORGANIZACIONES HAITIANAS DE DERECHOS HUMANOS (POHDH). La MINUSTAH y la violación de los derechos humanos en Haití: Violación de los derechos humanos por la Misión de las Naciones Unidas para la Estabilización de Haití. Puerto Príncipe, 15 de Febrero de 2012.

POLGREEN, L.; WEINER, T. Haiti's President Forced Out; Marines Sent to Keep Order. The New York Times. 29/02/2004. Disponível em: $<$ https://www.nytimes.com/2004/02/29/international/americas/haitis-

president-forced-out-marines-sent-to-keep. html>. Acesso em: $20 \mathrm{dez}$. 2018.

PORTO-GONÇALVES, C. A Reinvenção dos Territórios: a experiência latino-americana e caribenha. In: CECEÑA, A. Los desafíos de las emancipaciones en un contexto militarizado. Buenos Aires: CLACSO, 2006. 
PORTO-GONÇALVES, C. Apresentação da Edição em Português. In: LANDER, E. (Org.). A colonialidade do saber: eurocentrismo e ciências sociais - perspectivas latino-americanas. Buenos Aires: CLACSO, 2005.

POUSADELA, I. O contratualismo hobbesiano (ou de como para entender do direito é necessário pensar do avesso). In: BORÓN, A. (Org.). Filosofia política moderna: de Hobbes a Marx. Buenos Aires: CLACSO/San Pablo: Depto. de Ciência Política - FFLCH - Universidade de São Paulo, 2006.

PUGH, M. The political economy of peacebuilding: a critical theory perspective. International Journal of Peace Studies, vol. 10, n. 2, p. 2342, Autumn/Winter, 2005.

PRADAL, F. A perversa "pacificação" do Rio de Janeiro: comentários a partir de um assassinato na favela do Jacarezinho. Esquerda online, 09/04/2013. Disponível em: <https://blog.esquerdaonline.com/?cat=80>. Acesso em: 20 dez. 2018.

PRADO JR, C. História Econômica do Brasil. São Paulo: Brasiliense, 1979.

QUIJANO, A. Colonialidade do poder, eurocentrismo e América Latina. In: LANDER, E. (Org.). A colonialidade do saber: eurocentrismo e ciências sociais - perspectivas latino-americanas. Buenos Aires: CLACSO, 2005.

. Coloniality of power and eurocentism in Latin America. International Sociology, vol. vol. 15, n. 2, p. 215-232, 2000.

. ¡Qué tal raza!. Revista del CESLA, n. 1, p. 192-200, nov. 2000.

REDE JUBILEU SUL/BRASIL e REDE JUBILEU SUL AMÉRICAS. Haiti: Soberania e Dignidade - Missão Internacional de Investigação e Solidariedade com o Haiti. 1 ed. São Paulo: Expressão Popular, 2007.

REIS, J. J. Há Duzentos anos: a revolta escrava de 1814 na Bahia. Topoi, vol. 15, n. 28, p. 68-115, jan./jul., 2014.

"Nos achamos em campo a tratar da liberdade": a resistência negra no Brasil oitocentista. In: Motta, C. G. (Org.). Viagem Incompleta: a experiência brasileira (1500-2000). São Paulo: Senac, 2000.

. O jogo duro do Dois de Julho: o "Partido Negro" na Independência da Bahia. In: REIS, J.J.; SILVA, E. (Orgs.). Negociação e conflito: a resistência negra no Brasil escravista. São Paulo: Companhia das Letras, 1989.

. Quilombos e revoltas escravas no Brasil. Revista USP, vol. 28, p. 14-39, dezembro/fevereiro, 1995-1996. 
RICHMOND, O. The Transformation of Peace. London: Palgrave Macmillan, 2005.

. UN peace operations and the dilemmas of the peacebuilding consensus. International Peacekeeping, vol. 11, n. 1, p. 83-101, January, 2007.

RICOT, J. P. Note de presse de la PAPDA sur la MINUSTAH et les déclarations de Mme Sandra HONORÉ. PAPDA. 16/09/2014. Disponível em: <http://www.papda.org/article.php3?id article=1244>. Acesso em: 20 dez. 2018.

ROSSIER, N. Aristide and the endless revolution. Baraka Productions. 80 min. USA, 2005.

ROSTOW, W. Etapas do desenvolvimento econômico: um manifesto não comunista. Rio de Janeiro: Zahar, 1961.

SABARATNAM, M. Avatars of Eurocentrism in the critique of the liberal peace. Security Dialogue, vol. 44, n. 3, p. 259-278, 2013.

SAID, E. Culture \& Imperialism. London: Vintage Books, 1994.

. Orientalism. London: Penguin Classics, 2003.

SALLES, R. O Império do Brasil no contexto do século XIX. Escravidão nacional, classe senhorial e intelectuais na formação do Estado. Almanack, n. 4, p. 5-45, 2ํㅡㄴ semestre de 2012.

SANTIAGO. A. (Org.). Haiti por si: a reconquista da independência roubada. Fortaleza: Expressão Gráfica e Editora, 2013.

SANTOS, M. O Luso-tropicalismo como modelo ideológico da gestão colonial portuguesa. Revista Militar, n. 2549/2550, jun./jul., 2014.

SCARAMAL, E. Haiti: fenomenologia de uma barbárie. Goiânia: Cânone Editorial, 2006.

SCHMITT, C. The Concept of the political. Expanded Edition. Chicago/London: The University of Chicago Press, 2007.

SCHWARCZ, L.; STARLING, H. Brasil: uma biografia. São Paulo: Companhia das Letras, 2015.

SCOTT, D. Conscripts of Modernity: the tragedy of colonial enlightenment. Durham: Duke University Press, 2004.

. Modernity that Predated the Modern: Sidney Mintz's Caribbean. History Workshop Journal, Issue 58, n. 1, p. 191-210, 2004. 
SEGUY, F. A catástrofe de janeiro de 2010, a "Internacional Comunitária" e a recolonização do Haiti. Campinas, 2014, 398p. Tese de Doutorado - Universidade Estadual de Campinas, Instituto de Filosofia e Ciências Humanas. Orientador: Ricardo Antunes.

. Humanitarismo e questão racial no Haiti. Lutas Sociais, vol.19 n.34, p. 143-157, jan.jun. 2015.

SEITENFUS, R. Elementos para uma diplomacia solidária: a crise haitiana e os desafios da ordem internacional contemporânea. Carta Internacional, vol. 1, n. 1, p. 5-12, março, 2006.

Haiti: A Soberania dos Ditadores. Porto Alegre: Solivros, 1994.

. Hillary Clinton and Haiti". Counter Punch, 11/04/2016. Disponível em: <https://www.counterpunch.org/2016/04/11/hillary-clinton-and-haiti/>. Acesso em: 20 jun. 2018.

Reconstruir Haití: entre la esperanza y el tridente imperial. Santo Domingo: CLACSO/Fundación Juan Bosch, 2016.

SILVA, E. A ocupação da Maré pelo Exército brasileiro: percepção de moradores sobre a ocupação das Forças Armadas na Maré. Rio de Janeiro: Redes da Maré, 2017.

SILVA, L.G. El impacto de la revolución de Saint-Domingue y los afrodescendientes libres en Brasil: esclavitud, libertad, configuración social y perspectiva atlántica (1780-1825). Historia, n. 49, vol. 1, p. 209-233, Enero-Junio, 2016.

SILVA, R. Rio De Janeiro: A Local Response to a Global Challenge: An Interview with Col. Robson Rodrigues Da Silva. Journal of International Affairs, vol. 66, n. 1, Fall/Winter, 2012.

SMITH, R. Pat Robertson: Haiti cursed after pact with the devil. CBS News, 12/04/2010. Disponível em: <https://www.cbsnews.com/news/patrobertson-haiti-cursed-after-pact-to-the-devil/> . Acesso em: 20 dez. 2018.

SODRÉ, N. História da Imprensa no Brasil. 4. ed. Rio de Janeiro: Mauad, 1999.

SOTO, S. Haiti: 100 anos de ocupação. Jubileu Sul Américas; Jubileu Sul Brasil; Memória Latina; PAPDA. 25min. Manágua, Porto Príncipe e Rio de Janeiro, 2015.

SOUZA NETO, D. O Brasil, o Haiti e a MINUSTAH. In: KENKEL, K.; MORAES, R. (Orgs.). O Brasil e as operações de paz em um mundo globalizado: entre a tradição e a inovação. Brasília: IPEA, 2012. 
SPIVAK, G. Can the subaltern speak? In: GROSSBERG, L; NELSON, C. (eds). Marxism and the interpretation of culture. Basingstoke: Macmillan Education, 1988.

TAYLOR, I. Liberal Peace, Liberal Imperialism: a Gramscian critique. In: RICHMOND, O. (Org.). Palgrave advances in peacebuilding: critical developments and approaches. London: Palgrave Macmillan, 2010.

TRACHTENBERG, M. Intervention in Historical Perspective. In: KAYSEN, C.; REED, L. (Eds.). Emerging Norms of Justified Intervention. Cambridge, MA: American Academy of Arts and Sciences, 1993.

TROUILLOT, M.R. Silencing the Past: power and the production of history. Boston: Beacon Press, 1995.

The Odd and the Ordinary: Haiti, the Caribbean, and the World. Cimarrón: New Perspectives on the Caribbean, vol, 2, n. 3, p. 3-12, 1990.

ULYSSE, G. Why Haiti Needs New Narratives: A Post-Quake Chronicle. Trilingual Edition. Middletown, Connecticut: Wesleyan University Press, 2015.

UNITED NATIONS. A More Secure World: Our Shared Responsibility. Report of the Secretary-General's High-Level Panel on Threats, Challenges and Change. UN: New York, 2004.

. Security Council - Resolution 1529, adopted at its $4919^{\text {th }}$ meeting, on $29^{\text {th }}$ February 2004.

. Security Council - Resolution 1542, adopted at its $4961^{\text {st }}$ meeting, on 30 $0^{\text {th }}$ April 2004.

UPP - UNIDADE DE POLÍCIA PACIFICADORA. Prefeito de Cité Soleil visita UPP Fazendinha no Complexo do Alemão. Governo do Estado do Rio de Janeiro - Acontece. 03/07/2013. Disponível em: $<$ http://www.uppri.com/index.php/acontece/acontece-selecionado/prefeitode-cite-soleil-visita-upp-fazendinha-no-complexo-do-alemaeo/CPP>. Acesso em: 10 dez. 2018.

VALLER FILHO, W. O Brasil e a Crise Haitiana: a cooperação técnica como instrumento de solidariedade e de ação diplomática. Brasília: FUNAG, 2007.

VIANA, S. A Minustah e a participação brasileira. Revista Senso Comum, n.1, Dossiê Temático, p. 22-37, 2009.

VIANNA, O. Problemas de Política Objetiva. 1 ed. São Paulo: Companhia Editora Nacional, 1930. [2. ed. publicada em 1945]. 
VICTOR, G. Cures et châtiments. Montreal: Ed. Memoire d`Encrier, 2013.

VIEIRA NETO, F. Epopeia Militar Brasileira no Haiti. In: HAMANN, E.; TEIXEIRA, C. (Orgs.). A participação do Brasil na MINUSTAH (20042017): percepções, lições e práticas relevantes para futuras missões. Edição especial - coletânea de artigos. Rio de Janeiro: Igarapé/CCOPAB, 2017.

VIOTTI DA COSTA, E. Da Senzala à Colônia. 5. ed. São Paulo: UNESP, 2010.

VITALIS, R. The graceful and Generous Liberal Gesture: Making Racism Invisible in American International Relations. Millennium: Journal of International Studies, vol. 29, n. 2, p. 331-356, June, 2000.

VIVA RIO. Opiniões do Viva Rio sobre a intervenção federal na segurança pública. Viva Rio - Notícias. 06/03/2018. Disponível em: $<$ http://www.vivario.org.br/opinioes-do-viva-rio-diante-da-intervencaofederal-na-seguranca-publica/>. Acesso em: 20 dez. 2018.

VOLTAIRE NET. Missão Internacional disse que no Haiti está em jogo o futuro do Sul. Arquivo. 13/04/2005. Disponível em: $<$ https://www.voltairenet.org/article124673.html.> Acesso em: $20 \mathrm{dez}$. 2018.

WALKER, R. Inside/Outside: Relações Internacionais como teoria política. Rio de Janeiro: Ed. PUC-Rio/Editora Apicuri, 2013.

. Lines of insecurity: international, imperial, exceptional. Security Dialogue, v. 37, n. 1, p. 65-82, March, 2006.

. The Double Outside of the Modern International. Ephemera: theory \& politics in organization, vol, 6, n. 1, p. 56-69, 2006.

WEISS, T. Humanitarian intervention: ideas in action. Cambridge: Polity Press, 2007.

WEDNT, A. Social Theory of International Politics. Cambridge: Cambridge University Press, 1999.

YOUSSEF, A. Haitianismo em perspectiva comparativa: Brasil e Cuba (sécs. XVIII-XIX). Curitiba, Anais do 4 Encontro Escravidão e Liberdade no Brasil Meridional, 13-15 de maio de 2009.

ZEHFUSS, M. Constuctivism and Identity: Dangerous Liason. European Journal of Internatioanal Relations, vol. 7, no 3, 2001.

. Culturally sensitive war? The Human Terrain System and the seduction of ethics. Security Dialogue, vol. 43, n. 2, p. 175-190, 2012. 